
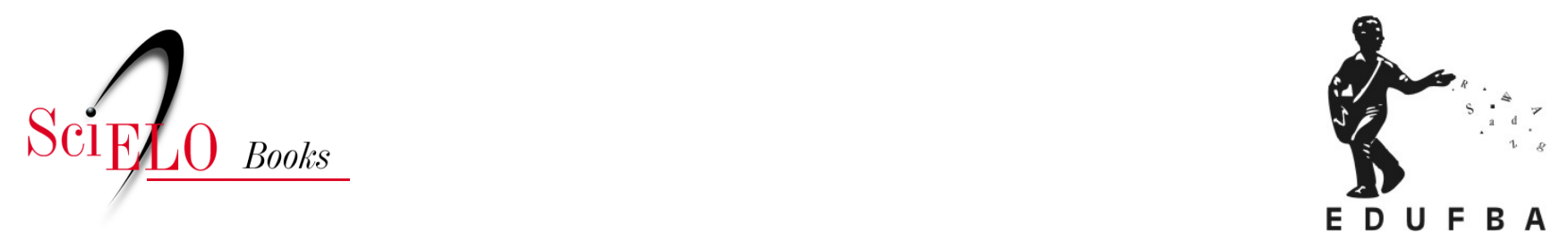

\title{
Violência de gênero contra mulheres suas diferentes faces e estratégias de enfrentamento e monitoramento
}

\author{
Cecilia M. B. Sardenberg \\ Márcia S. Tavares \\ (orgs.)
}

SARDENBERG, C.M.B., and TAVARES, M.S. comps. Violência de gênero contra mulheres: suas diferentes faces e estratégias de enfrentamento e monitoramento [online]. Salvador: EDUFBA, 2016, 335 p. Bahianas collection, vol. 19. ISBN 978-85-232-2016-7.

https://doi.org/10.7476/9788523220167.

All the contents of this work, except where otherwise noted, is licensed under a Creative Commons Attribution 4.0 International license.

Todo o conteúdo deste trabalho, exceto quando houver ressalva, é publicado sob a licença Creative Commons Atribição 4.0.

Todo el contenido de esta obra, excepto donde se indique lo contrario, está bajo licencia de la licencia Creative Commons Reconocimento 4.0. 


\section{UNIVERSIDADE FEDERAL DA BAHIA}

Reitor

João Carlos Salles Pires da Silva

Vice-Reitor

Paulo Cesar Miguez de Oliveira

Assessor do Reitor

Paulo Costa Lima

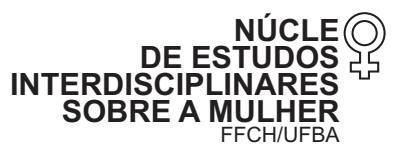

NEIM

Diretora

Rosângela Costa Araújo

Vice-Diretora

Laila Andressa Cavalcante Rosa

Comissão Editorial

Alda Britto da Motta

Cecília M. B. Sardenberg Ivia Alves

Silvia Lúcia Ferreira

Coordenação Editorial Executiva

Eulália Azevedo Ivia Alves

Maria de Lourdes Schefler Ângela Maria Freire de Lima e Souza

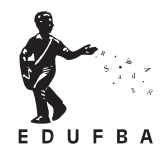

EDITORA DA UNIVERSIDADE FEDERAL

DA BAHIA

Diretora

Flávia Goullart Mota Garcia Rosa

Conselho Editorial

Alberto Brum Novaes

Angelo Szaniecki Perret Serpa

Caiuby Alves da Costa

Charbel Niño El Hani

Cleise Furtado Mendes

Dante Eustachio Lucchesi Ramacciotti

Evelina de Carvalho Sá Hoisel

José Teixeira Cavalcante Filho

Maria Vidal de Negreiros Camargo 
Cecilia M. B. Sardenberg Márcia S. Tavares

(Org.)

\section{Violência de gênero contra mulheres}

suas diferentes faces e estratégias de enfrentamento e monitoramento

COLEÇÃOBahianas, 19

Salvador | EDUFBA | 2016 
2016, Autores.

Direitos para esta edição cedidos à Edufba.

Feito o Depósito Legal.

$1^{\text {a }}$ reimpressão: 2018

Grafia atualizada conforme o Acordo Ortográfico da Língua Portuguesa de 1990, em vigor no Brasil desde 2009.

Projeto gráfico capa e miolo

Alana Gonçalves de Carvalho Martins

\author{
Editoração \\ Igor Fonsêca de Araújo Almeida \\ Revisão e normalização \\ Mariclei dos Santos Horta \\ Tainá Amado Basílio
}

Sistema de bibliotecas - UFBA

Violência de gênero contra mulheres : suas diferentes faces e estratégias de enfrentamento e monitoramento / Cecilia M. B. Sardenberg, Márcia S. Tavares (Org.) - Salvador : EDUFBA, 2016.

335 p. - (Coleção bahianas ; v. 19)

Coletânea de trabalhos apresentados durante o I Seminário Internacional: políticas de enfrentamento à violência de gênero contra mulheres, realizado conjuntamente ao XVI Simpósio Baiano de Pesquisadoras(es) sobre mulheres e relações de gênero, de 8 a 11 de novembro de 2010 (Salvador, BA).

ISBN 978-85-232-1503-3

1.Violência contra as mulheres. 2. Crime contra as mulheres. 3. Feminismo. 4. Mulheres Condições sociais. 5. Mulheres - Saúde e higiene. 6. Violência conjugal. 7. Violência contra as mulheres - Legislação - Brasil. I. Sardenberg, Cecília M. B. II. Tavares, Márcia S.

CDD - 362.83

Editora filiada à

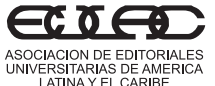

LATINAY YEL DARIBE

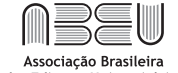

Associação Brasileira

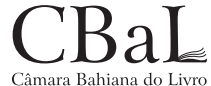

Câmara Bahiana do Livro

$$
\begin{aligned}
\text { NEIM } & \text { Editora da UFBA } \\
\text { Estrada de São Lázaro } & \text { Rua Barão de Jeremoabo } \\
197-\text { Federação } & \text { s/n - Campus de Ondina } \\
\text { 40210-630 - Salvador - Bahia } & 40170-115-\text { Salvador - Bahia } \\
\text { Tel.: +55 71 3237-8239 } & \text { Tel.: +55 71 3283-6164 } \\
\text { www.neim.ufba.br } & \text { Fax: +55 713283-6160 } \\
\text { neim@ufba.br } & \text { www.edufba.ufba.br } \\
& \text { edufba@ufba.br }
\end{aligned}
$$




\section{SUMÁRIO}

7 INTRODUÇÃO

Cecilia Maria Bacellar Sardenberg e Márcia Santana Tavares

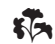

17 O FEMINISMO E O ENFRENTAMENTO DA VIOLÊNCIA CONTRA AS MULHERES NO BRASIL

Leila Linhares Barsted

41 MONITORANDO A LEI MARIA DA PENHA reflexões sobre a experiência do Observe Cecilia Maria Bacellar Sardenberg, Márcia Santana Tavares e Márcia Queiroz Gomes

69 ANÁLISE DAS DECISÕES DO SUPERIOR TRIBUNAL DE JUSTIÇA NOS CASOS DE VIOLÊNCIA DOMÉSTICA E FAMILIAR CONTRA A MULHER

Maria Terezinha Nunes e Maria Gabriela Hita

93 CONSTITUCIONALIDADE DA LEI MARIA DA PENHA Rúbia Abs da Cruz

109 SAÚDE E VIOLÊNCIA DE GÊNERO necessário monitoramento Telia Negrão 
145 A SEGURANÇA PÚBLICA NO ATENDIMENTO ÀS MULHERES uma análise a partir do Ligue 180

Alinne de Lima Bonetti, Luana Pinheiro e Pedro Ferreira

187 A LEI MARIA DA PENHA E SUA APLICAÇÃO NAS DEAMs DE SALVADOR

reflexões sobre o que pensam e dizem as mulheres em situação de violência

Ermildes Lima da Silva, Simone Oliveira de Lacerda, Márcia Santana Tavares

205 SISTEMATIZAÇÃO DE DADOS DA PRODUÇÃO DE SERVIÇOS DE ATENÇÃO À MULHERES EM SITUAÇÃO DE VIOLÊNCIA proposta de um grupo de trabalho

Cândida Ribeiro Santos, Maria Eunice Kalil e Suely Maria Costa Lobo

223 REDE DE ATENÇÃO À MULHER E À ADOLESCENTE EM SITUAÇÃO DE VIOLÊNCIA NO MUNICÍPIO DE JUAZEIRO/BA (RAMA/JUA) implantação, limites e desafios

Jayce Layana Lopes Callou e Juliana Sampaio

247 A VIOLÊNCIA CONTRA A MULHER EM MACEIÓ

o perfil dos agressores

Andréa Pacheco de Mesquita

267 VIOLÊNCIA DE GÊNERO NA TRAMA GERACIONAL

Eulália Lima Azevedo

293 MÚSICA E VIOLÊNCIA

narrativas do divino e feminicídio

Laila Andressa Rosa

327 QUEM É QUEM 


\title{
INTRODUÇÃO
}

\author{
Cecilia M. B. Sardenberg \\ Márcia Santana Tavares
}

A presente coletânea reúne trabalhos apresentados durante o I Seminário Internacional: Políticas de Enfrentamento à Violência de Gênero contra Mulheres, realizado conjuntamente ao XVI Simpósio Baiano de Pesquisadoras(es) sobre Mulheres e Relações de Gênero, no período de 8 a 11 de novembro de 2010, no campus da Universidade Federal da Bahia (UFBA), em Salvador, Bahia. O evento esteve sob a coordenação do Núcleo de Estudos Interdisciplinares sobre a Mulher (NEIM), em parceria com o Observatório de Monitoramento da Aplicação da Lei Maria da Penha (Observe), contando com o apoio da Secretaria de Políticas para Mulheres da Presidência da República e do Department for Foreign International Development (DFID), do Reino Unido, por intermédio do Projeto Pathways of Women's Empowerment Trilhas do Empoderamento de Mulheres (TEMPO).

Desde a criação do NEIM, em 1983, sua equipe vem promovendo diferentes eventos para incentivar o crescimento dos estudos feministas na Bahia, abrindo espaços para o debate e intercâm- 
bio entre profissionais da área. Com esse intuito, a partir de 1995, iniciamos a promoção de simpósios anuais (depois realizados de dois em dois anos), voltados a princípio para estudantes, pesquisadoras/es e demais profissionais atuantes no estado da Bahia, ampliando e elegendo, a cada ano, o seu âmbito e uma temática específica, respectivamente. Seguindo essa tradição, a equipe do Observe propôs ao NEIM a realização de um evento conjunto voltado para discussões acerca das diferentes manifestações de violência de gênero contra as mulheres, bem como das diversas iniciativas e experiências para coibi-la em nosso país, com ênfase nas políticas públicas e seu monitoramento - proposta esta aceita de imediato pela equipe do NEIM.

No nosso entender, violência de gênero diz respeito a qualquer tipo de violência (física, social ou simbólica) que tenha por base a organização social dos sexos e que seja perpetrada contra indivíduos especificamente em virtude do seu sexo, identidade de gênero ou orientação sexual. Dentro dessa perspectiva, a violência de gênero pode atingir tanto homens quanto mulheres, como se verifica no caso da violência contra homossexuais e transexuais, vítimas constantes de todo tipo de agressão. Entretanto, histórica e numericamente, é a violência masculina contra mulheres e, em especial, a violência doméstica, que tem se constituído como fenômeno de maior destaque, vez que não se manifesta apenas como fenômeno estruturado pela organização social de gênero nas sociedades contemporâneas, mas também como fator estruturante dessas sociedades.

A violência contra as mulheres foi reconhecida pela Organização das Nações Unidas (ONU) como uma forma de discriminação e violação de direitos humanos, tal qual delineado na sua Declaration on the Elimination of Violence Against Women (DEVAW) - Declaração pela Eliminação da Violência Contra as Mulheres (1993, Resolução 48/104). Nesse e em vários outros do- 
cumentos da ONU estão incluídas importantes recomendações para a criação e implementação de mecanismos de combate a esse tipo de violência. Destacam-se, dentre eles, mecanismos de monitoramento e facilitação da implementação dessas recomendações, com realce, no âmbito nacional, para os "mecanismos autônomos e independentes", tais como observatórios de monitoramento, para dar conta do controle social, necessário para a eficácia da legislação em vigor.

Sem dúvida, esse reconhecimento se constitui como conquista dos movimentos feministas e de mulheres, seja no âmbito internacional como no nacional, para tornar visível e politizar a violência com base nas ideologias de gênero. Somente a partir da emergência do feminismo contemporâneo nos anos 1960, a violência contra as mulheres, particularmente a violência doméstica e familiar, começou de fato a ser confrontada, tornando-se problema de ordem social. No Brasil, esse processo só foi deslanchado na década de 1970, ganhando espaço, desde então, como uma das principais bandeiras dos movimentos de mulheres e feministas, avançando, também, como uma das questões levantadas por esses movimentos que têm recebido maior atenção por parte do Estado.

Nos últimos anos, sobretudo a partir de 2003, com a criação da Secretaria Especial de Políticas para Mulheres (SPM), o Governo Federal tem investido em políticas públicas de enfrentamento à violência contra as mulheres, desenvolvendo ações diversificadas. Em 2004, uma articulação de organizações não governamentais e especialistas na temática da violência contra as mulheres conseguiu elaborar e encaminhar ao Executivo Federal um projeto de lei tendo em vista o Enfrentamento à Violência Doméstica e Familiar contra a Mulher (Lei n. 11.340), mais conhecida como Lei Maria da Penha (LMP), que foi sancionada em 2006, entrando em vigor no mesmo ano. 
A Lei Maria da Penha se constitui em uma reconhecida conquista dos esforços empreendidos pelos movimentos de mulheres e feministas, setores governamentais e não governamentais. Tem por objetivo maior criar "mecanismos para coibir e prevenir a violência doméstica e familiar contra a mulher" (artigo $1^{\circ}$ ), baseando-se na Constituição Federal (art. 226, parágrafo 8), na Convenção sobre a Eliminação de Todas as Formas de Violência contra a Mulher, na Convenção Interamericana para Prevenir, Punir e Erradicar a Violência contra a Mulher, entre outros tratados internacionais ratificados pelo Brasil. Essa Lei dispõe também sobre a criação dos Juizados de Violência Doméstica e Familiar contra a Mulher e estabelece medidas de assistência e proteção às mulheres em situação de violência doméstica e familiar, além de prescrever a necessidade de uma ação ampla e integral na prevenção e no combate a essa violência por parte dos diversos níveis de governo e do Poder Judiciário, e também de setores organizados da sociedade civil. Dessa forma, a construção de mecanismos para acompanhamento da boa aplicação da LMP se impõe como tarefa fundamental no combate à violência doméstica e familiar contra as mulheres.

Criado a partir da iniciativa da SPM com esse objetivo, o Observe, sediado no NEIM, vem desenvolvendo um conjunto de ações para acompanhar a implementação e aplicação da Lei Maria da Penha. Procura, assim, identificar avanços e dificuldades para a sua efetiva e plena aplicabilidade, buscando gerar informações úteis para os movimentos de mulheres e para as instituições públicas responsáveis pelas políticas públicas de enfrentamento da violência doméstica e familiar contra as mulheres.

O I Seminário Internacional: Políticas de Enfrentamento à Violência de Gênero Contra Mulheres, realizado conjuntamente ao XVI Simpósio Baiano de Pesquisadoras(es) sobre Mulher e Relações de Gênero, integrou essas ações. O evento abriu espaço 
para se aprofundar essa questão, possibilitando uma troca de saberes e experiências importantes para se refletir sobre as variadas expressões de violência de gênero contra a mulher - violência sexual, violência institucional, violência simbólica, assédio moral, violência doméstica e familiar entre outras - nos mais diferentes espaços sociais e institucionais onde são estabelecidas as relações e se reafirmam as desigualdades de gênero, bem como para a identificação de problemas e limitações no âmbito das políticas públicas para construção da equidade de gênero e as experiências de monitoramento. Tais discussões atravessaram as falas de todas as convidadas das mesas redondas, que procuraram não só avaliar as políticas públicas, mas também os nossos estudos, pesquisas e práticas. Os trabalhos incluídos nesta coletânea representam apenas uma parcela dessas discussões, mas acreditamos que trazem uma importante contribuição para pensarmos a violência de gênero no Brasil e nas estratégias para coibi-la.

\section{Os trabalhos nesta coletânea}

Abrimos esta coletânea com o texto de Leila Linhares Barsted, "O feminismo e o enfrentamento da violência contra as mulheres no Brasil”, no qual a autora realiza um balanço de mais de três décadas de luta feminista para que o Estado brasileiro reconhecesse a violência perpetrada contra as mulheres como um problema social e fossem produzidas mudanças no campo jurídico, mas também criadas políticas públicas para garantir proteção social às mulheres em situação de violência. Seu olhar atento aponta avanços, mas não se esquiva de sinalizar para a advocacy feminista os desafios a serem ainda superados para assegurar o acesso das mulheres à justiça, mas, principalmente, para eliminar a violência contra as mulheres no Brasil. Leila Barsted participou do Consórcio que elaborou a minuta da Lei Maria da Penha, in- 
tegrando também o Consórcio responsável pelo Observe, representando o Centro de Cidadania, Estudo, Pesquisa e Ação (Cepia).

No capítulo seguinte, "Monitorando a Lei Maria da Penha: reflexões sobre a experiência do Observe", de autoria de Cecilia M. B. Sardenberg, Márcia S. Tavares e Márcia Q. Gomes - integrantes da coordenação do Observe à época da realização do Seminário -, o enfoque recai na experiência do Observe, particularmente na construção de uma metodologia de monitoramento da implementação e aplicação da Lei Maria da Penha e sua validação, revelando os impasses, tensões e alguns resultados obtidos nesse processo. De um lado, a discussão gira em torno do processo de articulação do Consórcio e sua relação com o Estado, e de outro, da construção dos indicadores pertinentes aos procedimentos metodológicos para o monitoramento. As autoras ressaltam que, apesar dos problemas enfrentados, a sistematização dos dados levantados possibilitou conhecer melhor as soluções propostas por operadores do Direito e servidores para a realização dos trabalhos, bem como desvendar os possíveis entraves para que a aplicação da Lei Maria da Penha ocorra de forma integral. Em especial, o mapeamento das iniciativas exitosas na aplicação da Lei contribui para a formulação de recomendações para a melhoria dos serviços em todo o país.

Na sequência, Maria Terezinha Nunes e Maria Gabriela Hita, no capítulo "Análise das decisões do Superior Tribunal de Justiça nos casos de violência doméstica e familiar contra a mulher", apresentam resultados parciais de uma pesquisa sobre práticas judiciárias em casos de violência doméstica contra a mulher nos primeiros quatro anos de aplicação da Lei Maria da Penha, a partir da análise das decisões do Superior Tribunal de Justiça. A análise do material obtido revelou, entre outros problemas, a dificuldade dos operadores do Direito em conceberem essa violência como uma violação dos direitos humanos das mulheres, o que não só compromete o atendimento, como também evidencia o descumprimento da Lei. 
Segue-se com o capítulo "Constitucionalidade da Lei Maria da Penha”, em que a autora Rúbia Abs da Cruz, que participou também do Consórcio responsável pela elaboração da minuta de Lei Maria da Penha, bem como do Observe, representando a ONG feminista Themis - Gênero e Justiça, registra as ações políticas e jurídicas que embasam a análise de dispositivos da Lei Maria da Penha - Ação Direta de Constitucionalidade (ADC 19) e Ação Direta de Inconstitucionalidade (ADI 4424) - no Supremo Tribunal Federal (STF). A autora tece considerações acerca dos argumentos apresentados por ministros e ministras para endossarem o princípio do tratamento desigual às mulheres, com base em sua histórica desigualdade perante os homens no âmbito doméstico. Realça, também, a importância do Consórcio formado por ONGs e núcleos de universidades que, junto com a SPM, tanto elaboraram o modelo do projeto de lei e lutaram pela aprovação da Lei Maria da Penha, como se mantêm atuantes para assegurar sua efetiva aplicação.

No próximo capítulo, intitulado "Saúde e violência de gênero, necessário monitoramento", Telia Negrão - outra autora que participou do Observe, nesse caso, como secretária da Rede Feminista de Saúde, parceira do Observe - discute a questão da violência sexual e da saúde sexual e reprodutiva, com ênfase no acesso à atenção aos agravos e na interseção entre violência de gênero e Vírus da Imunodeficiência Humana (HIV/Aids), para enfatizar a importância da elaboração de estratégias de advocacy, monitoramento e controle social, tanto para o movimento de mulheres quanto para os gestores de políticas públicas. Ao longo do texto, a autora apresenta um panorama sobre os estudos científicos centrados em violência e saúde e aborda a ausência de acolhida e visibilidade das mulheres em situação de violência no sistema de saúde, para finalmente sugerir alguns caminhos a serem adotados no que se refere ao monitoramento em interface com saúde, em particular para o 
Observe, a primeira experiência de monitoramento no contexto da referida legislação.

No capítulo "A segurança pública no atendimento às mulheres: uma análise a partir do Ligue 180", Alinne Bonetti, Luana Pinheiro e Pedro Ferreira se debruçam sobre as reclamações registradas no Ligue 180 relativas ao atendimento prestado nos serviços de segurança pública a mulheres em situação de violência doméstica e familiar, de modo a rastrear falhas, abusos e situações de despreparo com as quais as mulheres se deparam em sua busca por apoio do Estado.

No capítulo seguinte, intitulado "A Lei Maria da Penha e sua aplicação nas DEAMs de Salvador: reflexões sobre o que pensam e dizem as mulheres em situação de violência”, Ermildes Lima da Silva, Simone Oliveira de Lacerda e Márcia Santana Tavares apresentam resultados de uma pesquisa realizada nas DEAMs de Salvador/BA. A pesquisa teve como objetivo monitorar a aplicabilidade da Lei Maria da Penha, com ênfase na articulação entre a rede de serviços, a partir da ótica de mulheres em situação de violência que buscam os serviços de proteção e apoio, de modo a conhecerem os procedimentos e encaminhamentos no âmbito institucional e a compreensão dessas mulheres acerca da violência contra a mulher e da Lei Maria da Penha.

Um outro olhar sobre enfrentamento da violência contra as mulheres é trazido por Cândida Ribeiro Santos, Maria Eunice Kalil e Suely Maria Costa Lobo no artigo intitulado "Sistematização de dados da produção de serviços de atenção a mulheres em situação de violência: proposta de um grupo de trabalho". Nesse texto, as autoras procuram refletir sobre a proposta de trabalho do SubGT Informação - parte do Grupo de Trabalho da Rede de Atenção a Mulheres em Situação de Violência de Salvador e Região Metropolitana de Salvador -, que se propõe a realizar o "mapeamento estatístico" dos vários tipos de atendimento prestados pe- 
los serviços que compõem essa rede, sistematizar e analisar esses dados, produzindo e difundindo informações que contribuam para o acompanhamento dos serviços.

Segue-se o artigo de Jayce Layana Lopes Callou e Juliana Sampaio, sob o título "Rede de Atenção à Mulher e Adolescente em situação de violência no município de Juazeiro/BA (Rama/ Jua): implantação, limites e desafios”, que tem como objetivo refletir sobre o processo de implantação da rede de proteção às mulheres em situação de violência residentes em Juazeiro/BA. Busca-se, assim, desvendar as principais dificuldades encontradas nesse processo, tendo como parâmetro para suas considerações teórico-metodológicas o levantamento de documentos da Rama/Jua e a aplicação de entrevistas com atores envolvidos no processo de articulação da rede no município.

Já em "A violência contra a mulher em Maceió: o perfil dos agressores”, Andrea Pacheco de Mesquita socializa parte dos resultados obtidos com a pesquisa sobre mulheres vítimas de violência após a implementação da Lei Maria da Penha em Maceió/AL, que fundamentou sua dissertação de mestrado. Mais precisamente, a partir de uma perspectiva de gênero, ela reúne as informações contidas em Boletins de Ocorrências (BOs) referentes a 2008 e propõe-se a esboçar o perfil de homens agressores, com o intuito de oferecer subsídios ao poder público para a formulação de políticas públicas de enfrentamento à violência contra as mulheres.

Em sequência, o texto de Eulália Lima Azevedo, intitulado "Violência de gênero na trama geracional", socializa resultados de uma pesquisa realizada na Delegacia Especial de Atendimento ao Idoso da Bahia (Deati/BA), com o propósito de ressaltar a importância sobre a discussão relacionada à dimensão geracional da violência de gênero e o tratamento ainda tímido conferido a essa questão, tanto do ponto de vista da ação política quanto da atenção teórica, principalmente a sua ausência nas análises feministas. 
Esta coletânea se encerra com o texto de Laila Andressa Rosa, "Música e violência: narrativas do divino e feminicídio", que estuda a relação entre música e feminicídio na jurema, uma religião afro-indígena estudada no contexto de terreiro de culto aos orixás em Pernambuco. A partir da análise do texto de um ponto cantado que descreve $o$ assassinato de uma mestra, a autora desenreda a narrativa autobiográfica e histórica de uma mulher silenciada pela violência, para destacar o feminicídio material ou simbólico a que estão predestinadas as mulheres que ousam transgredir o padrão "respeitável” de família e maternidade.

Finalmente, cabe ressaltar que os textos aqui reunidos trazem reflexões de pesquisadoras de diferentes partes do Brasil que dialogam entre si sobre a violência contra as mulheres e suas formas de enfrentamento. As experiências de pesquisa compartilhadas enfatizam lacunas, tensões e desafios a serem superados para o acesso das mulheres à justiça, ao mesmo tempo em que revelam nuances ainda pouco exploradas da violência e apontam caminhos a serem trilhados. Esperamos que esta publicação possa suscitar questionamentos, análises e críticas sobre o tema, bem como reforçar a importância da formulação/implementação de políticas públicas voltadas para a prevenção e combate à violência contra as mulheres.

Salvador, julho de 2014 


\section{O FEMINISMO E O ENFRENTAMENTO DA VIOLENNCIA CONTRA AS MULHERES NO BRASIL}

Leila Linhares Barsted

\section{Introdução}

A violência contra as mulheres continua sendo uma triste realidade no Brasil e no mundo. A cotidianidade dessa violência tem o poder de ofuscar sua visibilidade e descriminalizá-la no imaginário social e até mesmo, especificamente, no imaginário das mulheres. Longe de considerar essa violência como apenas pessoal e cultural, Charlotte Bunch (1991) destaca a sua conotação política na medida em que é o resultado das relações de poder, de dominação e de privilégio estabelecidas na sociedade em detrimento das mulheres. Para essa autora, a violência contra as mulheres é mecanismo primordial para manter essas relações políticas na família, no trabalho e em todas as esferas públicas.

Desde a década de 1960, os movimentos feministas de diversos países, articulados internacionalmente, deram visibilidade social 
às distintas formas de discriminações e de violências contra as mulheres, construindo uma agenda política que foi decisiva para a construção legislativa e doutrinária internacional. Essa agenda, orientada pelos princípios da igualdade e da equidade de gênero e do respeito à dignidade da pessoa humana, exigia que as mulheres fossem reconhecidas como sujeitos de direitos humanos, com necessidades específicas. Para além do avanço legislativo, as feministas exigiam políticas de Estado eficazes, capazes de superar de fato as discriminações e violências contra as mulheres, presentes nas práticas, nas mentalidades e nos costumes das sociedades.

Piovesan (1996) destaca que a primeira fase de proteção dos direitos humanos foi marcada pela tônica da proteção geral, genérica e abstrata, com base na igualdade formal, tal como definido na Declaração Universal dos Direitos Humanos. (ONU, 1948)

A segunda fase, especialmente a partir da década de 1960, foi marcada pela especificação do sujeito de direito, que passa a ser visto em suas peculiaridades e particularidades. Nessa ótica, determinados sujeitos de direitos ou determinadas violações de direitos exigem uma resposta específica e diferenciada; é reconhecido, assim, o direito à diferença como um direito fundamental ao lado do direito à igualdade.

Sob a influência e pressão dos movimentos feministas, a Organização das Nações Unidas (ONU) aprovou, em 1967, a Declaração sobre a Eliminação da Discriminação contra as Mulheres. Em 1972, a Assembleia Geral da ONU proclamou o ano de 1975 como o Ano Internacional das Mulheres, demonstrando preocupação com as violações dos direitos humanos das mulheres em todo o mundo. A ONU realizou, nesse mesmo ano, na cidade do México, a I Conferência Mundial das Mulheres, que impulsionou a aprovação, em 1979, pela Assembleia Geral das Nações Unidas, da Convenção para a Eliminação de todas as Formas de Discriminação contra as Mulheres - Declaration on the Elimination of Violence 
Against Women (Cedaw), ${ }^{1}$ dando valor jurídico à Declaração de 1967. Essa Convenção em muito se beneficiou dos princípios e orientações normativas da Convenção contra a Eliminação de todas as Formas de Discriminação Racial (CERD) (ONU, 1967, 1969), ${ }^{2}$ aprovada pela Assembleia Geral das Nações Unidas em 1965. Essa duas convenções são paradigmáticas, pois além de definirem o conceito de discriminação, ${ }^{3}$ incluíram no direito internacional a questão da diversidade humana e a necessidade da criação de proteções especiais voltadas para sujeitos tradicionalmente privados de direitos ou da sua totalidade, ampliando a compreensão da Declaração Universal dos Direitos Humanos, de 1948. (ONU, 1948)

A CERD e a Cedaw reconheceram que, em quase todos os países do mundo, as discriminações por motivo de sexo e de raça/ etnia produziam vulnerabilidades maiores para determinados grupos e que, portanto, proteções especiais deveriam ser promovidas pelos Estados-Membros signatários dessas Convenções. Ou seja, entendia-se que a diversidade humana não poderia ser tomada como fator para discriminações, mas deveria promover o reconhecimento de direitos especiais. Para tanto, não se consideraria como discriminação as medidas especiais temporárias tomadas com o único objetivo de assegurar o progresso adequado que tais grupos necessitam para que possam usufruir de direitos humanos e liberdades fundamentais.

Além das discriminações e dos obstáculos encontrados pelas mulheres ao acesso a direitos civis, políticos, econômicos, sociais

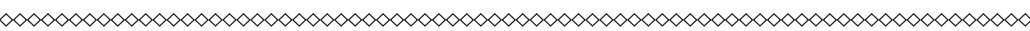

1 O Brasil assinou, em 1984, essa Convenção, mantendo reserva na parte das disposições relativas ao direito de família, que na época era extremamente hierárquico em nossa legislação civil. Em 1994, o Brasil retirou as reservas, ratificando plenamente essa Convenção.

2 Essa Convenção foi ratificada pelo Brasil em 1968.

30 Artigo 1 da CERD e o Artigo 1 da Cedaw definem, praticamente com as mesmas palavras, a discriminação racial e a discriminação contra as mulheres, respectivamente, como toda distinção, exclusão, restrição ou preferência baseada em raça ou em sexo que tenha como objetivo ou resultado anular ou restringir o reconhecimento, fruição e exercício de direitos humanos e liberdades fundamentais nos campos político, econômico, social, cultural ou em qualquer outro campo. (ONU, 1979, 1967) 
e culturais, os movimentos feministas de diversos países denunciaram em fóruns internacionais a ocorrência de violências sofridas pelas mulheres na vida pública e no espaço privado. Sob o slogan de que "o privado é político", trouxeram para o debate público a problemática das relações familiares marcadas por desigualdades em prejuízo das mulheres.

Dez anos após a Conferência do México, em 1985, antes da realização da III Conferência Mundial das Mulheres, em Nairobi, as Nações Unidas enviaram aos Estados-Membros um questionário ${ }^{4}$ sobre o cumprimento da Convenção de 1979, com o objetivo de avaliar seu impacto na vida das mulheres, os avanços e obstáculos à sua realização. Apesar de poucos Estados-Membros terem respondido a esse questionário, diversas organizações de mulheres em todo o mundo apresentaram suas avaliações, que, em muitos casos, contrariavam as otimistas avaliações oficiais dos EstadosMembros. Tais avaliações permitiram que se apresentasse, em Nairobi, um diagnóstico preocupante que revelava ao mundo a grave situação das mulheres em todos os países: o lento avanço da incorporação pelos Estados-Membros de suas reivindicações e dos compromissos internacionais e a persistência das discriminações expressas de diversas formas, das mais sutis às mais cruéis.

Face a tal constatação, a Conferência de Nairobi, orientada e fortalecida pela decisiva participação dos movimentos de mulheres de diversoso países, traçou metas para o futuro, consubstanciadas em ações concretas que deveriam ser implementadas para superar as discriminações e as desigualdades de gênero e proporcionar o desenvolvimento das mulheres.

Nesses últimos quase 40 anos, os movimentos feministas têm lutado não apenas pela eliminação das discriminações sociais e

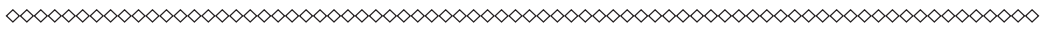

4 A Convenção prevê em seu texto a apresentação pelos Estados-Membros de relatórios periódicos sobre o seu cumprimento. 0 Estado brasileiro só entregou o primeiro relatório em 2002, apresentado perante o Comitê previsto nessa convenção em 2003. 
legislativas e por ampliação de direito, mas também pela necessidade das mulheres serem titulares de fato dos direitos formais conquistados. Tal processo significa aumentar as potencialidades das mulheres para enfrentar e superar as discriminações. Isso implica na promoção constante de uma advocacy feminista voltada para o empoderamento das mulheres. A noção de empoderamento das mulheres indica uma constante atividade de mobilização política em todas as direções - Estado, sociedade e relações interpessoais para mudar políticas, leis, comportamento e valores discriminatórios e construir uma sociedade verdadeiramente plural e democrática.

Para tanto, os movimentos feministas, ampliados como movimentos de mulheres em diversos países, incluindo o Brasil, têm dirigido ações de advocacy para o desenvolvimento e implementação de políticas públicas que contemplem o reconhecimento de direitos, a correspondência entre esses direitos e os costumes, valores, comportamentos e práticas sociais. Da mesma forma, tais movimentos têm atuado na promoção e na difusão dos direitos formalmente já assegurados, incentivando as mulheres a praticar sua cidadania e a se mobilizar para a efetivação da titularidade de seus direitos.

Conhecer e difundir esse processo de advocacy pode fortalecer a luta feminista para implementar as conquistas alcançadas e avançar na superação de obstáculos que ainda mantêm alta a incidência da violência contra as mulheres. Concordando com Ecléa Bosi de que "A memória é um cabedal infinito do qual só registramos um fragmento", é de grande importância fazermos um esforço para articularmos os fragmentos da trajetória do feminismo no Brasil, de forma compor e valorizar um processo político de grande importância. 


\section{A advocacy feminista no Brasil}

No Brasil, a existência de organizações e movimentos de mulheres possibilitou a constituição de um sujeito coletivo que alargou o campo democrático. Esse novo sujeito tem sido capaz de advogar pela ampliação e pelo acesso de direitos; de articular-se com outros movimentos sociais para a construção de uma cidadania cada vez mais inclusiva e respeitadora das diferenças; de imprimir novos paradigmas políticos e culturais; de monitorar o Estado e a sociedade no que diz respeito à compatibilidade entre as declarações de direitos e à sua efetividade; de participar de fóruns internacionais de direitos humanos.

Os movimentos de mulheres no Brasil, desde seu início, não contestavam apenas a estrutura política e econômica de dominação, mas se propunha a aprofundar questões culturais e a formar um campo político específico. O engajamento das feministas na luta contra a ditadura foi fundamental para caracterizar o feminismo brasileiro como uma força política na defesa da democracia.

A diversidade desse novo movimento social expressava-se pelas múltiplas formas de organização e reivindicações e também pela ausência de estrutura hierárquica. Outra característica importante desse movimento foi sua composição social, étnico/ racial e regional, incorporando mulheres trabalhadoras urbanas e rurais, empregadas domésticas, sindicalistas, mulheres negras, mulheres militantes de partidos políticos de oposição à ditadura, estudantes, profissionais liberais, dentre outras. Adquiriu, em pouco tempo, um caráter nacional com uma larga agenda comum e se espalhou pelo país numa época em que as tecnologias atuais de comunicação, como a internet, ainda não estavam disponíveis.

As organizações feministas brasileiras tiveram a capacidade de compreender que a luta por cidadania implica a superação de hierarquias temáticas na medida em que os direitos humanos são 
indivisíveis. Nesse sentido, a agenda feminista mostrou-se ampla, abrangendo as questões do trabalho urbano e rural, da renda, da participação política e social, da saúde, da sexualidade e do aborto, da discriminação étnico-racial, do acesso à terra, do direito a uma vida sem violência, dentre outros temas e questões que precisavam ser incluídos na arena pública e continuam atuais. (UNIFEM, 2002, 2012)

A luta legislativa por igualdade, incluindo nas relações familiares, teve destaque importante nessa agenda na medida em que significava o rompimento com a lógica patriarcal da subordinação feminina. A conquista por direitos formais foi, assim, o passo inicial do feminismo brasileiro.

No processo de luta por direitos, as organizações e os movimentos de mulheres constituíram um campo de poder que tem sido decisivo para a manutenção dos direitos conquistados e para a possibilidade de conquista de novos direitos. Esse processo de luta por direitos, voltado para a eliminação de todas as formas de discriminação e de violência, apresenta, ao longo das últimas quase quatro décadas, um conjunto de importantes avanços legislativos e de políticas públicas que não pode ser subestimado. Tem como perspectiva a possibilidade de contribuir para a ampliação do acesso à justiça, a partir da mudança de uma cultura jurídica ainda marcada pela concepção da dominação masculina. (BOURDIEU, 1999)

A luta pelo direito a uma vida sem violência, que possibilitou a aprovação da Lei Maria da Penha em 2006, é um caso exemplar de advocacy feminista. Esse processo político aponta a longa interlocução sistemática das feministas com os poderes legislativo e executivo e, mais recentemente, com o poder judiciário.

Ao longo desse processo, as organizações e movimentos de mulheres ganharam legitimidade social e credibilidade política. As denúncias e as demandas apresentadas à sociedade e ao Estado 
para o enfrentamento da violência contra as mulheres tiveram por base uma militância informada por dados qualitativos e quantitativos, por estudos confiáveis de fontes fidedignas. Também tiveram por fonte a interlocução constante com movimentos de mulheres de base, a presença das feministas no debate público e no processo de redemocratização, sua atuação em fóruns internacionais, especialmente nos espaços das conferências de direitos humanos da década de 1990.

\section{Um pouco da história da advocacy feminista contra a violência}

No Brasil, a advocacy feminista na defesa dos direitos das mulheres e no enfrentamento da violência específica que sobre elas recai tem seu surgimento em meados da década de 1970. Inspirados no feminismo europeu e norte-americano e nos avanços produzidos pela ONU, surgiram grupos formados por mulheres feministas, participantes, em grande parte, do movimento de resistência à ditadura militar. Tais grupos, inicialmente organizados como grupos de reflexão, além de enfrentarem a crítica dos setores conservadores, eram vistos por setores progressistas como "divisionistas", porque para eles a questão das mulheres parecia irrelevante, reacionária e até mesmo motivo de piada.

Deve-se destacar que, desde a década de 1960, a contribuição de mulheres intelectuais como Heleieth Safiotti, Carmen da Silva, Heloneida Studart, Moema Toscano, Rose Marie Muraro, Lélia Gonzalez, Fanny Tabak, Eva Blay, dentre outras, já denunciava, em livros, artigos e reportagens, a opressão das mulheres. Muitas delas chegaram ao feminismo através da leitura da obra de Simone de Beauvoir (1967), que chamava atenção sobre a posição de "segundo sexo" que as mulheres ocupavam na sociedade, fruto de uma cultura de desempoderamento explicitada por meio de um 
processo de socialização contínua, daí sua famosa frase "Ninguém nasce mulher: torna-se mulher."

Com a inauguração, em 1975, pelas Nações Unidas da chamada década das mulheres e a realização da I Conferência Internacional das Mulheres, no México, esses grupos feministas se empenharam para provocar, no Brasil, a repercussão da temática dos direitos das mulheres. Assim, com o apoio do escritório local da ONU e sob a coordenação de um grupo de mulheres, ${ }^{5}$ realizou-se, no Rio de Janeiro, o Seminário sobre o Papel e o Comportamento das Mulheres na Sociedade Brasileira, momento inaugurador do novo movimento feminista em nosso país. ${ }^{6}$ Nesse seminário, que teve a duração de uma semana, as questões principais foram as denúncias das diversas formas de discriminação que recaíam sobre as mulheres e a importância da luta pela liberdade e igualdade de direitos, especialmente em um país marcado por uma ditadura militar que se iniciara em 1964. Nesse contexto político, o movimento de mulheres no Brasil surgiu com uma dupla identidade: de um lado, fazia parte do movimento contra a ditadura, de outro, apresentava-se como um ator social novo na luta pelo reconhecimento da condição das mulheres enquanto problemática social.

No Seminário de 1975, as feministas brasileiras se organizaram em torno de propostas específicas de luta contra todas as demais formas de discriminação, incluindo as diferentes formas de violência. O rol de temas apresentados nesse Seminário abrangia: a

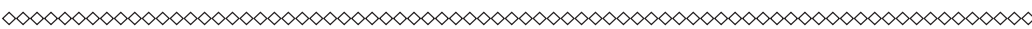

5 O Seminário sobre o Papel e o Comportamento das Mulheres na Sociedade Brasileira, realizado em 1975, no Rio de Janeiro, na sede da Associação Brasileira de Imprensa (ABI), teve como organizadoras Leila Linhares Barsted, Mariska Ribeiro, Maria Luiza Heilborn, Branca Moreira Alves, Jacqueline Pitanguy, Diva Mucio Teixeira, Elice Munerato, Miriam Campello, dentre outras. Ver a respeito a matéria do Centro Latino-Americano em Sexualidade e Direitos Humanos (CLAM), por ocasião do Seminário 30 anos Ininterruptos de Feminismo no Brasil, realizado no Rio de Janeiro em 2005, junto com a Articulação de Mulheres Brasileiras. A luta e a denúncia sobre a incidência da violência contra as mulheres e pela descriminalização do aborto não foi explicitada na Carta Final do Seminário, ver a respeito a Programação e a Carta Final do Seminário (CLAM, 2005).

6 No Brasil, a primeira onda feminista está exemplificada na luta das sufragistas. Ver a esse respeito Alves (1980). 
desigualdade legal e de fato nas relações familiares e de trabalho, ${ }^{7}$ a desigualdade salarial, de melhores oportunidades de emprego e de ascensão profissional, a ausência do direito à regulação da fertilidade, os estereótipos no sistema de ensino e nos meios de comunicação, a discriminação contra as mulheres negras, a dificuldade de acesso a serviços de saúde eficientes e outras marginalizações, incluindo aquelas relativas às mães solteiras, homossexuais e prostitutas.

Desse seminário, saiu o compromisso de criação, ${ }^{8}$ no mesmo ano, do Centro da Mulher Brasileira, no Rio de Janeiro. Também a partir daí, surgiu uma imprensa feminista com os jornais Nós mulheres, Brasil mulher, Mulherio, dentre outros.

As denúncias de violências contra as mulheres foram pontos que estiveram presentes desde as primeiras manifestações do feminismo brasileiro, ainda na década de 1970. Muitas dessas denúncias relativas à violência específica contra as mulheres e praticadas por agentes do Estado não tiveram publicidade face à vigência da ditadura militar. De fato, naquela época, relatos de presas políticas assinalavam que muitas militantes, além de terem sido torturadas em seus órgãos genitais, também foram vítimas de abusos sexuais.

Também, mesmo ainda não sendo tipificado como crime, em fins dessa década, o assédio sexual foi denunciado pelas feministas, quando uma funcionária de um jornal do Rio de Janeiro foi assediada por seu chefe. As feministas fizeram manifestação de rua, no Rio de Janeiro, em frente ao prédio desse jornal, dando visibilidade a uma violência rotineiramente cometida contra as mulheres, em especial contra trabalhadoras domésticas.

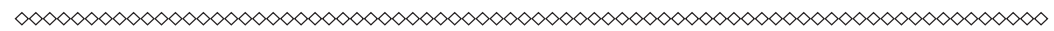

7 Destaca-se que, ainda naquela década, um grupo de advogadas feministas levou ao Congresso Nacional um projeto de mudança no Código Civil, especificamente na parte relativa ao direito de família, onde a discriminação legal contra elas limitava seus direitos de cidadania.

8 Ver matéria do CLAM (2005), da Universidade Estadual do Rio de Janeiro (UERJ), quando da comemoração, em 2005, dos 30 anos de feminismo no Brasil. 
Ainda na década de 1970, em face da reiterada absolvição de homens que assassinaram suas mulheres alegando a "legítima defesa da honra", feministas organizadas em diversos estados brasileiros deram início a uma grande campanha nacional, com destaque nas ruas e na mídia, sob o slogan "quem ama não mata". Essa campanha tornou possível, no início dos anos de 1980, a condenação de homens que assassinaram suas companheiras, até então impunes apesar de seus crimes.

Ao longo da década de 1980, a esperança na renovação do Estado brasileiro levou grupos de mulheres a se organizarem em torno de propostas específicas de luta contra a violência e todas as demais formas de discriminação. Para avançarem nessas propostas, as feministas buscaram, já no início dessa década, uma interlocução com o Estado, seja nas poucas brechas possíveis no final da ditadura, seja no processo de redemocratização e na continuidade do restabelecimento da democracia no Brasil. Empreenderam esforços, também, em relação aos meios de comunicação.

Assim, na década de 1980, tendo o Estado - que se democratizava - como alvo principal de sua ação política, as feministas elaboraram propostas que ampliaram aquelas da Carta de 1975: direitos civis, em especial a igualdade nas relações familiares, direitos sociais no campo do trabalho e da ascensão profissional, a ampliação da licença maternidade, o acesso de seus filhos a creches, direitos individuais no que se refere à decisão de ter ou não ter filhos e o direito a uma vida sem violência. Já no início da década de 1980, a agenda feminista incluía, além da luta legislativa, a pressão junto ao poder executivo, nos níveis nacional e estadual, para a criação de mecanismos institucionais de defesa dos direitos das mulheres e serviços capazes de atender as mulheres em situação de violência. A partir de 1982, estados como São Paulo, Minas Gerais e Rio de Janeiro passaram a contar com Conselhos Estaduais e Delegacias de Mulheres. Em 1985, com a criação do 
Conselho Nacional dos Direitos das Mulheres, as demandas feministas foram incluídas na agenda política do Governo Federal, que estimulou, em boa medida, articulado ao movimento de mulheres, a expansão desses serviços nos estados e municípios.

Especialmente no plano nacional, o Conselho Nacional dos Direitos da Mulher (CNDM) teve papel fundamental, em permanente diálogo com os movimentos de mulheres, na promoção da campanha "Constituinte pra valer tem que ter a palavra da mulher" e na elaboração da Carta das Mulheres aos Constituintes. Essa Carta culminou em um grande processo de discussão de mulheres de todo o país, de diferentes segmentos sociais, que se deslocaram, em diversos momentos, para Brasília, em verdadeiras caravanas, passando dias e dias debatendo e apresentado suas sugestões para a elaboração desse histórico documento. (PITANGUY, 2003)

A Carta incluiu todas as reivindicações das mulheres para a concretização da cidadania das mulheres na vida pública e nos espaços privados. A atuação do CNDM junto às mulheres parlamentares federais deu origem ao chamado "lobby do batom", movimento fundamental para que, superando suas identidades partidárias, as deputadas federais defendessem as reivindicações contidas na Carta das Mulheres aos Constituintes. No período de 1986 a 1989, o CNDM, especificamente no que diz respeito à violência contra as mulheres, produziu uma grande campanha, com inserções na mídia, em que diversas personalidades formadoras de opinião se pronunciavam contra essa violência e promoveu a realização de pesquisa e publicação relativa aos resultados do acesso à justiça quando as vítimas eram mulheres. (PITANGUY, 2003)

A advocacy feminista, empreendida pelo CNDM e pelos movimentos de mulheres, especificamente no que se refere à violência, possibilitou a inclusão, na Constituição de 1988, de um importante parágrafo no artigo 226, que trata da família. Escrito por orientação do movimento de mulheres, o parágrafo $8^{\circ}$ reconhece que 
"o Estado assegurará a assistência à família na pessoa de cada um dos que a integram.” A Constituição Federal de 1988 reconheceu a igualdade de direitos de homens e mulheres na vida pública e na vida privada, bem como incorporou em seu texto inúmeros outros direitos individuais e sociais das mulheres. (BRASIL, 1988)

Apesar da desestruturação, pelo Governo Federal, do CNDM, em 1989, os movimentos de mulheres prosseguiram no diálogo com os governos estaduais para a criação e ampliação das Delegacias de Mulheres, de abrigos, de centros de referência e de serviços de saúde voltados paras mulheres vítimas de violência sexual.

No Brasil, os movimentos de mulheres compreenderam, antes mesmo do processo constituinte, que um elemento fundamental na demanda por políticas públicas sociais é a sua formalização legislativa, declarando direitos e criando a obrigação do Estado de garanti-los e implementá-los. Assim, a percepção da importância do processo legislativo levou o movimento feminista a atuar não apenas para incluir os direitos das mulheres na Constituição Federal, mas também nas constituições estaduais e na propositura de leis infraconstitucionais que completassem a cidadania feminina tolhida, por décadas, em grande parte, pelas disposições do Código Civil de 1916. (BARSTED; GARCEZ, 1999)

A cidadania formal das mulheres, completada com a Constituição Federal de 1988, aboliu as inúmeras discriminações contra elas, ${ }^{9}$ especialmente no âmbito da legislação sobre a família, coadunando-se com a Cedaw, de 1979. A partir dessa década, as feministas brasileiras empreenderam ações contínuas contra as diversas formas de violência contra as mulheres, incluindo as denúncias sobre a incidência da violência sexual cometida nos espa-

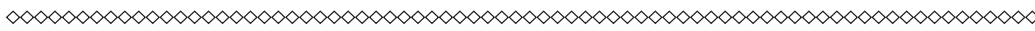
9 Exceção à manutenção da limitação de direitos trabalhistas às trabalhadoras domésticas. 
ços públicos, nas relações de trabalho, nas instituições do Estado ${ }^{10}$ e nas relações familiares.

Na década de 1990, a luta contra a violência se manteve na pauta política com a ampliação das Delegacias Especializadas e criação de novos serviços, como abrigos e centros de referência. Nessa década, o Superior Tribunal de Justiça (STJ) declarou a ilegalidade da chamada "tese da legítima defesa da honra", argumento da legislação colonial que se perpetuava nas decisões do júri popular. Esse Tribunal não foi insensível à campanha "quem ama não mata”, considerando a tese da legítima defesa da honra como antijurídica por expressar tão somente as relações de poder entre homens e mulheres.

Essa decisão é um importante divisor de águas na cultura jurídica brasileira. Não se pode esquecer que, mesmo considerando que a violência de gênero é um fenômeno que ocorre em quase todos os países, no Brasil essa violência foi, durante muitos séculos, garantida e absolvida pelo próprio Estado, a partir de uma tradição jurídica que justificava, por exemplo, o assassinato de mulheres por seus maridos nos chamados casos de legítima defesa da honra. Nesse sentido, não se pode subestimar o impacto ideológico das Ordenações Filipinas, que vigoraram no Brasil mesmo após a nossa independência. Essas Ordenações declaravam explicitamente o direito do marido de matar as suas mulheres por encontrá-las em adultério. (HERMAN; BASTED, 1995) Somente em 1840, tal direito foi revogado, embora fosse, ao longo das décadas seguintes, fartamente utilizado. A decisão do STJ foi, portanto, uma decisão histórica no enfrentamento da violência contra as mulheres.

As feministas brasileiras demonstram grande capacidade de diálogo e de articulação internacional, além de terem como estratégia de ação na luta contra a violência os avanços da normativi-

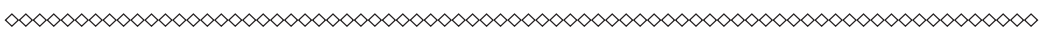
10 Não se pode esquecer que o alto índice de mortalidade maternal representa uma violência pela ação ou omissão de agentes do Estado. 
dade internacional promovidos pela ONU e pela Organização dos Estados Americanos (OEA). A ação feminista de advocacy no plano internacional, que incluiu os movimentos e grupos feministas do Brasil, ganhou força na década de 1990. Assim, em 1992, suprindo a ausência do tema da violência contra as mulheres na Cedaw e reconhecendo a magnitude e a gravidade desse fenômeno em todo o mundo e seu impacto sobre a vida das mulheres, a Assembleia Geral das Nações Unidas aprovou a Resolução n. 19 (ONU, 1992), sobre violência contra as mulheres, dispondo expressamente que a definição de discriminação contra as mulheres, prevista no artigo $1^{\circ}$ da Cedaw, incluiu a violência baseada no sexo, isto é, "aquela violência dirigida contra as mulheres porque é mulher ou que a afeta de forma desproporcional.” (ONU, 1992) A Assembleia Geral das Nações Unidas estabeleceu que essa Convenção aplica-se à violência perpetrada por agentes públicos ou privados. A Resolução n. 19 fortaleceu a compreensão de que a violência contra as mulheres é uma grave forma de discriminação que reflete e perpetua a subordinação das mulheres e que, para a sua superação, nas esferas pública e privada, exige-se a atuação dos Estados-Membros através de medidas legislativas e políticas sociais.

Em 1993, a Conferência Mundial de Direitos Humanos, realizada em Viena e que contou com a participação de feministas brasileiras em seu Fórum Paralelo das ONGs, produziu impacto na comunidade internacional ao reconhecer que os direitos das mulheres são direitos humanos e que a violência contra as mulheres e as meninas representa uma violação desses direitos, conclamando os Estados-Membros a adotarem a perspectiva de gênero em suas políticas como forma de eliminar a violência e a discriminação contra as mulheres.

O tema da violência contra as mulheres nas suas distintas formas de manifestação está presente também no Plano de Ação da Conferência Internacional sobre População e Desenvolvimento, 
realizada em 1994, no Cairo, que reconheceu ter a violência contra as mulheres profundos impactos sobre a saúde, em especial sobre a saúde sexual e reprodutiva das mulheres, conclamando os Estados-Membros a elaborar leis e implementar políticas para a eliminação dessas violências.

A Plataforma de Ação da IV Conferência Mundial das Mulheres, realizada em 1995, em Beijing, reforçou a importância do tema da violência contra as mulheres. Em um capítulo inteiro, compreende-se essa grave questão como um obstáculo à igualdade, ao desenvolvimento e à paz. A Plataforma chama atenção para o reconhecimento e proteção da liberdade das mulheres de tomarem decisões sobre suas vidas, incluindo as decisões nos campos da sexualidade e da reprodução, sem coerção, discriminação ou violência.

Avanço importante no plano nacional foi a ratificação, pelo Brasil, da Convenção para Prevenir, Punir e Erradicar a Violência contra as Mulheres - Convenção de Belém do Pará (OEA 1994), que apresenta a mais clara definição normativa de violência de gênero. ${ }^{11}$ Essa Convenção, que tem status legislativo nos países signatários, incluindo o Brasil, incorporou a definição contida na Declaração das Nações Unidas sobre a Eliminação da Violência contra as Mulheres. (ONU, 1992)

Pela Convenção de Belém do Pará, entende-se por violência contra as mulheres "qualquer ação ou conduta, baseada no gênero, que cause morte, dano físico, sexual ou psicológico à mulher, tanto no âmbito público como no privado." (OEA, 1994) A partir dessa Convenção, considera-se violência física qualquer conduta que ofenda a integridade física de uma pessoa. A violência psicológica é definida como qualquer conduta que vise degradar ou controlar as ações, comportamentos, crenças e decisões de ou-

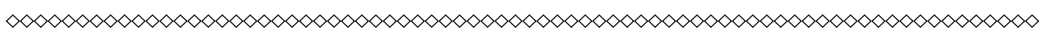

11 Essa Convenção, aprovada pela Assembleia Geral da OEA, foi ratificada pelo Estado brasileiro através do Decreto Legislativo 107. (BRASIL, 1995) 
trem por meio de ameaça direta ou indireta, humilhação, manipulação, isolamento ou o que cause prejuízo à saúde psicológica, à autodeterminação e ao desenvolvimento pessoal. A violência sexual é compreendida como qualquer conduta que constranja uma pessoa a manter contato sexual físico ou verbal, ou a participar de relações sexuais com uso da força, chantagem, suborno, manipulação, ameaça direta ou indireta ou qualquer outro meio que anule ou limite a vontade pessoal. Essas formas de violência podem ocorrer na família, no trabalho, na sociedade ou nas instituições do Estado. (OEA, 1994) ${ }^{12}$

A Convenção de Belém do Pará constituiu-se para os movimentos de mulheres no Brasil, em paradigma para a elaboração e implementação de uma política pública nacional de enfrentamento da violência de gênero contra as mulheres. Foi marco jurídico para a elaboração da Lei Maria da Penha.

Outro avanço importante nessa década, fruto do diálogo dos movimentos de mulheres com profissionais de saúde, foi a elaboração, em 1999, pelo Ministério da Saúde, da primeira Norma Técnica sobre Agravos da Violência Sexual (BRASIL, 1999), garantindo o direito ao abortamento legal previsto desde 1940, mas jamais disponibilizado às mulheres vítimas de violência sexual. Destaca-se nesse período a produção de estudos sobre a violência de agentes do Estado, em especial a violência contras mulheres presidiárias.

Na década de 2000, importantes mudanças no Código Penal fortaleceram o marco legal de enfrentamento da violência de gênero. Avanço institucional importante foi o reconhecimento, pelo Governo Federal, de status ministerial dado à Secretaria de Políticas para as Mulheres (SPM). Essa Secretaria intensifi-

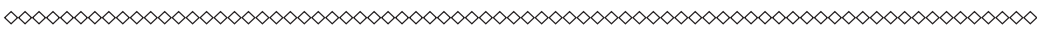

12 Em 2005, a OEA criou um Mecanismo de Monitoramento da Implementação da Convenção de Belém do Pará (MESECVI), formado por um órgão político; a Comissão Interamericana de Mulheres (CIM); e um comitê técnico, Comitê de Especialistas em Violência (CEVI), formado por especialistas autônomas de cada Estado-Membro.
} 
cou sua interlocução com os movimentos de mulheres e incorporou no Plano Nacional Pró-Equidade de Gênero e no Pacto de Enfrentamento da Violência contra as Mulheres as demandas apresentadas nas duas Conferências Nacionais de Mulheres. As Conferências têm sido momentos de encontro nacional dos diversos movimentos de mulheres existentes no país, congregando mulheres urbanas e mulheres do campo e da floresta.

A capacidade das feministas brasileiras de incorporar na sua atuação a normatividade, os princípios da doutrina e da jurisprudência oriundas do direito internacional dos direitos humanos, foi de fundamental importância para o enfrentamento da violência contra as mulheres. Tal capacidade propositiva resultou na elaboração e posterior aprovação, pela Presidência da República, da Lei Maria da Penha. (BRASIL, 2006) No período de 2002 a 2006, as feministas brasileiras, articuladas inicialmente em um consórcio de ONGs que reunia mulheres operadoras do Direito, foram capazes de produzir um texto legislativo que deu origem a essa Lei, incorporando a Convenção de Belém do Pará e as diversas recomendações dirigidas pela ONU ao Estado brasileiro.

Da mesma forma, as alterações do Código Penal, que eliminaram normas discriminatórias e favoráveis aos agressores, em grande medida responderam às demandas feministas e às recomendações do comitê da Cedaw, quando da apresentação do Relatório Nacional Brasileiro, em 2004. (BRASIL, 2008) Esse comitê recomendou que o Brasil elaborasse uma lei sobre a violência doméstica contra as mulheres, ratificando, dessa forma, as demandas das feministas brasileiras. ${ }^{13}$ Também nessa década, a violência contra Maria da Penha Fernandes e a impunidade de seu agressor, caso levado pelo Comitê Latino-americano e do Caribe

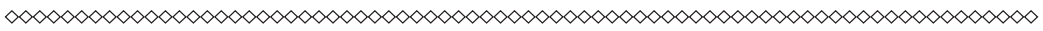

13 Os diversos Relatórios apresentados pelo Brasil junto ao Comitê Cedaw têm destacado os avanços alcançados e, também, as dificuldades para a implementação de políticas públicas eficazes que possibilitem atenção às mulheres em situação de violência. 
para a Defesa dos Direitos da Mulher (Cladem) e pelo Centro pela Justiça e o Direito Internacional (Cejil) à Comissão Interamericana dos Direitos Humanos (CIDH) da OEA, representou o início de uma capacidade postulante das feministas em Cortes Internacionais.

Na década de 2010, a advocacy feminista tem por alvo a atuação junto ao Poder Judiciário, poder ainda pouco conhecido e com o qual os movimentos de mulheres passaram a dialogar a partir da aprovação da Lei Maria da Penha. O diálogo com esse novo ator introduz duas questões: de um lado, a necessidade de sensibilizar o judiciário sobre o fenômeno da violência contra as mulheres, ainda de grande incidência e impunidade no Brasil; por outro lado, esse diálogo introduz um tema especialmente importante, considerando o grande avanço legislativo alcançado nos últimos 37 anos. Trata-se do ainda difícil acesso das mulheres à justiça. Seja tomando a justiça em seu sentido mais amplo, que inclui o acesso a todos os serviços de atenção às mulheres em situação de violência, seja em seu sentido estrito, relativo ao acesso das mulheres ao poder judiciário. Nos últimos seis anos, a resistência dos operadores do Direito, especialmente de juízes, para a implementação da Lei Maria da Penha demonstra o quanto se necessita atuar junto ao Poder Judiciário. A grande mobilização dos movimentos de mulheres encontrou eco no STF, que unanimemente declarou, em 2012, a plena constitucionalidade dessa Lei. No pronunciamento dos ministros desse Tribunal ficou patente o intenso trabalho de advocacy feminista. Esse trabalho político esteve voltado para a aprovação da constitucionalidade da Lei Maria da Penha, além de visar à incorporação pelos ministros dos documentos internacionais de proteção aos direitos humanos das mulheres. ${ }^{14}$

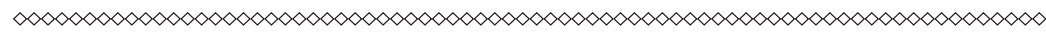

14 Na revisão desse artigo, destaco que, em março de 2015, foi aprovada pelo Congresso e sancionada pela Presidente da República a Lei n. 13.104, que alterou o Código Penal para incluir mais uma modalidade de homicídio qualificado, o feminicídio. (BRASIL, 2015) 
Além de sua capacidade de mobilização política, o feminismo brasileiro apresenta uma grande capacidade de produção intelectual. Ao longo das últimas décadas, os estudos sobre a violência de gênero contra as mulheres foram promovidos por diversas pesquisadoras, de diferentes organizações e instituições, que se empenham em revelar a magnitude das diversas formas de violência contra as mulheres, especialmente da violência doméstica e familiar e de compreender suas causas e consequências. Debruça-se, ainda, sobre a temática do acesso à justiça, questão que deve ganhar destaque na advocacy feminista. (PASINATO, 2012)

$O$ balanço de mais de três décadas no enfrentamento da violência contra as mulheres no Brasil revela a importante capacidade política dos movimentos de mulheres dirigida especialmente ao Estado. Esse balanço revela sucessos, no que se refere à superação da legislação sexista, à criação de mecanismos institucionais voltados para a atenção às mulheres em situação de violência, bem como uma abertura do poder judiciário para incorporar os instrumentos internacionais de proteção aos direitos humanos.

A ênfase da advocacy feminista na luta contra a violência doméstica e familiar não foi acompanhada de uma advocacy mais forte em relação a outras formas de violência contra as mulheres. Assim, é necessária a produção de mais estudos e levantamento de dados para dar maior visibilidade à violência sexual nas relações de trabalho ou em outros espaços institucionais, tipificada como assédio sexual, crime de difícil comprovação, pois geralmente ocorre quando a vítima está a sós com o assediador. A violência praticada por agentes públicos e privados contra outros grupos de mulheres em diferentes contextos - como aquelas vivenciadas pelas presidiárias, mulheres do campo e da floresta e mulheres afrodescendentes e indígenas - precisa merecer maiores esforços dos movimentos de mulheres para denunciá-la, ampliar sua visibilidade e para promover respostas do Estado e da sociedade 
capazes de diminuir a incidência e permitir o acesso dessas mulheres à justiça.

Além disso, a advocacy por acesso à justiça precisa ser intensificada considerando a existência de uma precária estrutura dos equipamentos para a atenção às mulheres em situação de violência; a frágil capacitação dos profissionais que atuam nos serviços; a não observância de protocolos de atenção de forma a criar redes institucionais formalmente articuladas; a concentração dos serviços na região Sudeste em detrimento das demais regiões do país. A pouca dotação de recursos orçamentários para os serviços públicos voltados para a atenção às mulheres em situação de violência apresenta-se como um forte inibidor do acesso das mulheres à justiça.

Apesar de todos os esforços dos movimentos feministas e também do Estado, a incidência da violência contra as mulheres no Brasil é extremante alta, conforme dados do IPEA (2014). A democracia brasileira não tem sido capaz de superar a forte resistência existente na sociedade no que concerne ao reconhecimento dos direitos humanos das mulheres. Os dados do Censo de 2010 revelam a permanência de discriminações contra as mulheres, em especial contra as mulheres negras, no que diz respeito, por exemplo, à renda, ao acesso aos meios produtivos e a uma boa assistência à saúde. Da mesma forma, os dados do Superior Tribunal Eleitoral (TSE, 2014) indicam a baixíssima representação feminina nos espaços de poder.

Recuperando a análise de Charlotte Bunch (1991), essa discriminação, que fortalece e é fortalecida pela prática costumeira da violência contra as mulheres, tem uma conotação política, resultado das relações de poder, de dominação e de privilégio estabelecidas na sociedade em detrimento das mulheres.

Mudar tais relações de poder é o grande desafio histórico que se coloca para a advocacy feminista. 


\section{Referências}

ALVES, B. M. Ideologia e feminismo - a luta da mulher pelo voto no Brasil. Rio de Janeiro: Vozes, 1980.

BARSTED, L. L.; GARCEZ, E. A legislação civil sobre a família no Brasil. In: BARSTED, L. L. (Org.). As mulheres e os direitos civis. Rio de Janeiro: Cepia, 1999.

BEAUVOIR, S. O segundo sexo. 2. ed. Rio de Janeiro: Difusão Européia do Livro, 1967.

BRASIL. VI Relatório Nacional Brasileiro: Convenção pela Eliminação de todas as Formas de Discriminação contra as Mulheres. Brasília: ONU/ Secretaria Especial de Políticas para as Mulheres, 2008. Disponível em: <http://www.spm.gov.br/central-de-conteudos/publicacoes/ publicacoes/2008/livrocedawweb.pdf $>$. Acesso em: 2015.

BRASIL. Constituição da República Federativa do Brasil. Brasília: Senado Federal, 1988. Disponível em: <http://www.planalto.gov.br/ ccivil_03/Constituicao/Constituicao.htm>. Acesso em: 2015.

BRASIL. Decreto legal 107. Aprova o texto da Convenção Interamericana para Prevenir, Punir e Erradicar a Violência contra a Mulher.

Disponível em: <ttp://www2.camara.leg.br/legin/fed/decleg/1995/ decretolegislativo-107-31-agosto-1995-364335-publicacaooriginal-1pl.html>. Acesso em: 2015

BRASIL. Lei 11.340 de 7 de agosto de 2006. Cria mecanismos para coibir a violência doméstica e familiar contra a mulher, nos termos do $§ 8^{\circ}$ do art. 226 da Constituição Federal, da Convenção sobre a Eliminação de Todas as Formas de Discriminação contra as Mulheres. Disponível em: <http://www.planalto.gov.br/ccivil_03/_ato2004-2006/2006/lei/ 111340.htm>. Acesso em: 2015.

BRASIL. Lei 13.104 de 9 de março de 2015. Altera o art. 121 do DecretoLei n n $^{2.848 \text {, de }} 7$ de dezembro de 1940 - Código Penal. Disponível em: < http://www.planalto.gov.br/ccivil_03/_Ato2015-2018/2015/Lei/ L13104.htm>. Acesso em: 2015.

BRASIL. Prevenção e tratamento dos agravos resultantes da violência sexual contra mulheres e adolescentes: Norma Técnica. Brasília, DF: Ministério da Saúde, 1999. 
BRASIL. Tribunal Superior Eleitoral, Título. Brasília, DF, 2014.

BOURDIEU, P. A dominação masculina. Rio de Janeiro: Bertrand Brasil, 1999.

BUNCH, C. Hacia una revisión de los Derechos Humanos. In: BUNSTER, X.; ENLOE, C.; RODRIGUES, R. (Org.). La mujer ausente: derechos humanos en el mundo. Santiago: Isis Internacional, 1991.

CARNEIRO, S. Mulheres negras, violência e pobreza. In: BRASIL. Diálogos sobre violência doméstica e de gênero. Brasília, DF: SPM, 2005.

CENTRO LATINO-AMERICANO EM SEXUALIDADE E DIREITOS HUMANOS (CLAM). Carta Final. Rio de Janeiro, 2005. Disponível em: <http://www.clam.org.br/default_home.asp>. Acesso em: 2015.

FUNDO DE DESENVOLVIMENTO DAS NAÇÕES UNIDAS PARA A MULHER (UNIFEM). O progresso das mulheres no Brasil 2012. Rio de Janeiro: CEPIA, 2012.

FUNDO DE DESENVOLVIMENTO DAS NAÇÕES UNIDAS PARA A MULHER (UNIFEM). O progresso das mulheres no Brasil 2002. Rio de Janeiro: CEPIA, 2002.

HERMAN, J.; BARSTED, L. L. O judiciário e a violência contra a mulher: a ordem legal e a (des)ordem familiar. Rio de Janeiro: CEPIA, 1995.

INSTITUTO DE PESQUISA APLICADA (IPEA). TÍTULO. Rio de Janeiro, 2014.

ORGANIZAÇÃO DAS NAÇÕES UNIDAS (ONU). Declaração Universal dos Direitos Humanos. Paris: ONU, 1948. Disponível em: <http://www. brasil.gov.br/cidadania-e-justica/2009/11/declaracao-universal-dosdireitos-humanos-garante-igualdade-social>. Acesso em: 2015.

ORGANIZAÇÃO DAS NAÇÕES UNIDAS (ONU). Declaração sobre a eliminação da discriminação contra as mulheres. [S.1.]: ONU Mulheres, 1967. Disponível em: <http://www.un.org/womenwatch/>. Acesso em: 2015.

ORGANIZAÇÃO DAS NAÇÕES UNIDAS (ONU). Declaração sobre a eliminação da discriminação contra as mulheres. [S.1.]: ONU Mulheres, 1979. Disponível em: <http://www.un.org/womenwatch/ daw/cedaw/cedaw.htm>. Acesso em: 2015. 
ORGANIZAÇÃO DAS NAÇÕES UNIDAS (ONU). Convenção contra a eliminação de todas as formas de discriminação racial. [S.1.]: CERD, 1969. Disponível em: <http:/ / legis.senado.gov.br/legislacao/ ListaTextoIntegral.action? $\mathrm{id}=94836>$. Acesso em: 2015.

ORGANIZAÇÃO NAÇÕES UNIDAS (ONU). Convenção sobre a eliminação de todas as formas de discriminação contra a mulher. [S.1.]: ONU Mulheres, 1979. Disponível em: <http://www.pge.sp.gov. $\mathrm{br} /$ centrodeestudos/bibliotecavirtual/instrumentos/discrimulher. htm>. Acesso em: 2015.

ORGANIZAÇÃO DAS NAÇÕES UNIDAS (ONU). Violencia contra las Mujeres. [S.1.]: ONU Mulheres, 1992. Disponível em: <http://www. un.org/womenwatch/daw/cedaw/recommendations/recomm-sp. htm>. Acesso em: 2015.

ORGANIZAÇÃO DOS ESTADOS AMERICANOS (OEA). Convenção De Belém Do Pará. Pará, 1994. Disponível em: <http: //www.cidh.org/ Basicos/Portugues/m.Belem.do.Para.htm>. Acesso em: 2015.

PASINATO, W. Acesso à justiça e violência contra a mulher em Belo Horizonte. São Paulo: AnnaBlume, 2012.

PIOVESAN, F. Direitos humanos e o direito constitucional internacional. São Paulo: Max Limonad,1996.

PITANGUY, J. As Mulheres e a Constituição de 1988. Revista Rio de Janeiro, v. X, n. X, 19--. Disponível em: <http://www.cepia.org.br/ images/nov089.pdf>. Acesso em: 2015.

PITANGUY, J. Movimento de mulheres e políticas de gênero no Brasil. In: LOBO, T.; PITANGUY, J.; MONTAÑO, S. As políticas públicas de gênero: um modelo para armar. O caso do Brasil. Santiago de Chile: CEPAL, 2003. p. 23-40. 


\section{MONITORANDO A LEI MARIA DA PENHA reflexões sobre a experiência do Observe ${ }^{1}$}

Cecilia Maria Bacellar Sardenberg

Márcia Santana Tavares

Márcia Queiroz Gomes

\section{Introdução}

A proposta deste trabalho é refletir sobre nossa experiência na Coordenação Nacional do Observatório de Monitoramento da Aplicação da Lei Maria da Penha (Observe) - sediado no Núcleo de Estudos Interdisciplinares sobre a Mulher da Universidade Federal da Bahia (NEIM/UFBA) -, que teve como principais objetivos, nos seus primeiros três anos de existência, a elaboração e aplicação de uma metodologia para o acompanhamento e avaliação do processo de implementação da referida Lei. Mais precisamente, pretendemos aqui discutir os impasses, tensões e alguns resultados obtidos desde a criação do Observe, detendo-nos, de um lado, no

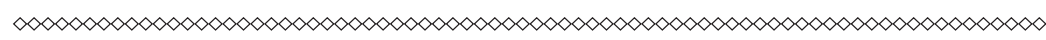

1 Uma primeira versão deste artigo foi publicada sob o título "Feminismo, Estado e políticas de enfrentamento à violência contra mulheres: monitorando a Lei Maria da Penha". (TAVARES; SARDENBERG; GOMES, 2011) 
processo de articulação do Consórcio e sua relação com o Estado, e de outro, no processo de construção dos indicadores pertinentes aos procedimentos metodológicos para o monitoramento.

Cabe observar que, durante a década de 1990, o Brasil participou e foi signatário das resoluções das Conferências da Organização das Nações Unidas (ONU) realizadas em Viena (1993), Cairo (1994) e Beijing (1995), com relevante ressonância para as mulheres em todo o mundo. Representantes do governo brasileiro assinaram também o Protocolo Opcional à Convenção sobre a Eliminação de Todas as Formas de Discriminação contra a Mulher (BRASIL, 2002), bem como a Declaração sobre a Eliminação da Violência contra a Mulher (ONU, 1993) e a Convenção Interamericana para Prevenir, Punir e Erradicar a Violência contra a Mulher (OEA, 1994), que ficou conhecida como Carta de Belém do Pará. Isso se traduziu em significativos avanços no que se refere à defesa dos direitos das mulheres. Contudo, no tocante ao enfrentamento da violência de gênero, foram registrados retrocessos.

Com efeito, em 1995, com a Lei n. 9.099 (BRASIL, 1995), foram instituídos os Juizados Especiais Criminais (JECrims), considerados revolucionários pela comunidade jurídica, uma vez que, acreditava-se, possibilitariam um maior acesso à justiça para a resolução de conflitos de natureza penal, quando o crime apresentasse "menor potencial ofensivo" - ou seja, quando se tratasse de lesões corporais leves e ameaças, para os quais era prescrita uma pena máxima de até um ano de detenção, justamente devido ao seu suposto "menor potencial ofensivo." (BARSTED, 2007)

A Lei n. 9.099/95 aplicava-se à maioria das denúncias feitas na Delegacia Especial de Atendimento à Mulher (DEAM) - precisamente, lesões corporais leves e ameaças -, o que contribuiu para reiterar a histórica banalização da violência contra a mulher. (AQUINO, 2009) A lei recomendava a conciliação entre as partes, permitia a "limpeza" da ficha dos acusados, que continuavam 
como réus primários, além de disponibilizar o recurso à transação penal, isto é, o acusado poderia optar pelo pagamento de uma multa. De fato, os(as) conciliadores(as), em nome da agilidade, não privavam o agressor de liberdade e apenas aplicavam uma multa, geralmente o pagamento de cestas básicas, como forma de reparar os danos causados, ignorando as particularidades das relações de gênero presentes nos conflitos e desconhecendo o caráter cíclico que caracteriza a violência contra a mulher. (QUEIROZ, 2008)

$\mathrm{Na}$ perspectiva feminista, essa Lei constituiu-se como um grande retrocesso no enfrentamento à violência contra a mulher. Conforme ressaltou Wânia Pasinato (2004, p. 18): “A classificação da violência como crime de menor potencial ofensivo, o pequeno número de ocorrências que chegam a uma decisão judicial e o tipo de decisão que tem sido ofertada são os principais eixos em que as críticas se articulam."

Frente a essa situação, organizações feministas e feministas acadêmicas passaram a refletir, debater e produzir conhecimento a respeito dos efeitos da Lei n. 9.099. (BRASIL, 1995) Após uma década de protestos contra os JECrims - e de recomendações explícitas do Comitê Cedaw, que avaliara o relatório do Brasil encaminhado em 2003 -, foi constituído um consórcio formado por organizações não governamentais (ONGs) e advogadas especialistas na temática da violência contra as mulheres, com a finalidade de elaborar uma proposta de lei que revogasse a competência dos JECrims para julgar os casos de violência doméstica e familiar contra a mulher.

Em 2004, a minuta de um projeto de lei, bastante avançado, de enfrentamento da violência doméstica foi entregue à deputada Jandira Feghali no Congresso Nacional, como também encaminhado ao Executivo Federal, por intermédio da Secretaria Especial de Políticas para Mulheres (SPM), criada pelo presidente Lula no ano anterior, com status de Ministério. 
Uma comissão interministerial, constituída pelo Governo Federal e contando com a participação de feministas integrantes das ONGs e redes responsáveis pela elaboração da minuta original, discutiu a proposta, também apresentada e discutida pelos movimentos de mulheres em várias capitais do país. Por quase dois anos, ONGs feministas fizeram lobby no Congresso para a aprovação da Lei; em 7 de agosto de 2006, o presidente Lula da Silva sancionou a Lei de Enfrentamento à Violência Doméstica e Familiar contra a Mulher (Lei n. 11.340), mais conhecida como Lei Maria da Penha, que entrou em vigor em setembro do mesmo ano. (BRASIL, 2006)

Essa denominação foi uma homenagem à professora Maria da Penha Maia Fernandes, paraplégica em virtude de violência doméstica e vitimada pelo Estado, que não lhe deu a assistência necessária para evitar tal situação. Passados 15 anos de agressão, Marco Antonio, o ex-marido agressor, continuava em liberdade, vez que ainda não havia uma decisão final de sua condenação por parte dos tribunais nacionais. Frente à impunidade favorecendo o agressor por parte do Estado brasileiro, em 1998, Maria da Penha, juntamente com as organizações Centro para a Justiça e o Direito Internacional (Cejil) e Comitê Latino-americano do Caribe para a Defesa dos Direitos da Mulher (Cladem), encaminhou à Comissão Interamericana de Direitos Humanos (CIDH), da Organização dos Estados Americanos (OEA), uma petição contra o Estado brasileiro, tendo por base a Convenção de Belém do Pará. ${ }^{2}$ A referida Comissão, após exame dos documentos encaminhados, acabou por condenar o Estado brasileiro por "negligência e omissão" no tocante à violência doméstica sofrida por Maria da Penha, recomendando o pagamento, por parte do Estado, da indenização à vítima. Destaca-se que:

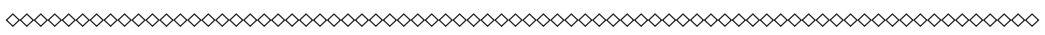

2 Convenção Para Prevenir, Punir e Erradicar a Violência contra as Mulheres, mais conhecida por Convenção de Belém do Pará, de 1994. 
o caso Maria da Penha foi o primeiro na aplicação da Convenção de Belém do Pará no Sistema Interamericano. E, de fato, a utilização da Convenção foi decisiva para que o processo fosse concluído e, posteriormente, para que o agressor fosse preso, em outubro de 2002, quase 20 anos após o crime, poucos meses antes da prescrição da pena. (AGENDE, 2007, p. 12)

Esses desdobramentos tiveram também relevância para a criação da Lei Maria da Penha, que veio trazer importantes inovações para a proteção de mulheres em situação de violência. Em especial, a Lei Maria da Penha:

- define e caracteriza a violência doméstica e familiar contra a mulher segundo as considerações das convenções internacionais;

- classifica as formas de violência doméstica contra a mulher - física, psicológica, sexual, patrimonial e assédio moral;

- extingue as penas pecuniárias, pagas com cesta básicas ou multas;

- determina que a violência doméstica independe de sua orientação sexual;

- retira dos juizados especiais a competência para apreciar os crimes de violência doméstica contra a mulher;

- prescreve a criação de juizados especiais de violência doméstica e familiar contra a mulher, com competência cível e criminal para abranger as questões familiares decorrentes da violência contra a mulher;

- altera o código do processo penal para permitir ao juiz a decretação de prisão preventiva diante de riscos à integridade física ou moral da mulher e possibilita a prisão em flagrante;

- aumenta a pena do crime de violência doméstica para de três meses a três anos; 
- altera a lei de execuções penais para possibilitar que o juiz determine o comparecimento obrigatório do agressor a programas de educação e reabilitação.

Essas importantes mudanças trazidas pela nova Lei foram reafirmadas com o II Plano Nacional de Políticas para as Mulheres (PNPM). ${ }^{3}$ O Plano II dedica o capítulo 4 ao enfrentamento de todas as formas de violência e considera prioritária a implementação da Lei Maria da Penha e demais normas jurídicas no âmbito nacional e internacional. (BRASIL, 2008) Para tanto, define como uma de suas principais metas a consolidação do Observatório Lei Maria da Penha. Já o capítulo 11, relativo à gestão e monitoramento do Plano, estabelece como prioridades, por exemplo, a implantação de um Sistema Nacional de Dados e Estatísticas sobre a violência contra as mulheres e a produção, organização e publicização de dados, estudos e pesquisas sobre as temáticas de gênero, raça/etnia e violência contra as mulheres, entre outras ações.

A Lei Maria da Penha é sustentada também pelo Pacto Nacional pelo Enfrentamento à Violência contra a Mulher (BRASIL, 2007), uma iniciativa do Governo Federal, dentro da Política de Enfrentamento, sob a coordenação da SPM, que objetivou promover, no período de 2008 a 2011, um conjunto de políticas públicas, executadas de forma articulada por ministérios e secretarias especiais, tendo em vista prevenir e enfrentar as diferentes formas de violência contra as mulheres, em função do maior grau de discriminação e vulnerabilidade social a que estão expostas. O Pacto Nacional tem como um dos seus objetivos específicos a redução dos índices de violência contra as mulheres, daí porque uma das áreas que o estruturam é a consolidação da Política Nacional de

$\infty<\infty<\infty<\infty<\infty<\infty<\infty<\infty<\infty<\infty<\infty<\infty<\infty<\infty<\infty<\infty<\infty<\infty<\infty<\infty<\infty<\infty<\infty<\infty<\infty<\infty<\infty<\infty<\infty<\infty<\infty<\infty$

3 A Il Conferência Nacional de Políticas para as Mulheres (CNPM), realizada em agosto de 2007, ao validar os princípios e pressupostos da Política Nacional para as Mulheres, assim como as diretrizes e prioridades indicadas pela I CNPM, ocorrida em 2004, aprovou as principais linhas do II PNPM. 
Enfrentamento à Violência contra as Mulheres, incluindo a implementação da Lei Maria da Penha.

As inovações introduzidas pela Lei Maria da Penha são incontestáveis no campo político e jurídico, mas a efetiva aplicação desse instrumento legal requer mudanças institucionais nas DEAMs e na criação dos Juizados Especiais de Violência Doméstica e Familiar contra a Mulher, assim como a capacitação da equipe de profissionais das DEAMs e Juizados Especiais, a implementação de uma rede serviços para os quais as mulheres em situação de violência doméstica e familiar e seus agressores possam ser encaminhados e a inclusão dessas mulheres em programas assistenciais, entre outras medidas. Além disso, a implementação da nova Lei demanda uma articulação mais eficaz dentre os órgãos incluídos na rede de atendimento a mulheres em situação de violência, que perpassa os âmbitos municipal, estadual e federal.

Nesse sentido, a SPM, com a finalidade de contribuir para a efetivação da Lei Maria da Penha, assumiu a coordenação do Pacto Nacional de Enfrentamento da Violência Contra as Mulheres e tem apoiado outros projetos e políticas do Governo Federal. Por iniciativa do Conselho Nacional dos Direitos da Mulher, um desses projetos resultou em edital para a criação de um observatório, com o propósito de monitorar e avaliar o processo de implementação e aplicação da lei em todo o país. A proposta para a criação do Observatório de Monitoramento da Aplicação da Lei Maria da Penha (Observe) foi a vencedora. No que se segue, veremos como se deu a sua articulação e como se definiu sua identidade e relação com o Estado.

\section{Tensões e desafios na construção do Observe}

O Observe foi organizado como uma instância autônoma da sociedade civil, formado por um consórcio que reuniu nove ONGs 
e núcleos de pesquisa universitários: Ações em Gênero (Agende); Núcleo de Estudos e Pesquisas sobre a Mulher (Nepem/UNB); Cidadania, Estudo Pesquisa, Informação e Ação (Cepia); Núcleo de Estudos de Políticas Públicas em Direitos Humanos da Universidade Federal do Rio de Janeiro (NEPP-DH/UFRJ); Coletivo Feminino Plural; Assessoria Jurídica e Estudos de Gênero (THEMIS); Núcleo Interdisciplinar de Estudos sobre a Mulher e Relações de Gênero (NIEM/UFRGS); Grupo de Estudos e Pesquisas Eneida de Moraes sobre Mulheres e Relações de Gênero (Gepem/UFPA).

A Rede Feminista de Saúde e Direitos Reprodutivos e Direitos Sexuais, a Rede Regional Feminista Norte e Nordeste de Estudos sobre Mulheres e Relações de Gênero (Redor) e o Cladem integraram o Consórcio como redes parceiras. Dentre essas entidade e redes, incluem-se algumas das que integraram o Consórcio que elaborou a primeira minuta da Lei (Agende, Cepia, THEMIS, Cladem), bem como da articulação de redes e entidades responsáveis pela elaboração do relatório "sombra" - o Relatório da Sociedade Civil apresentado ao Comitê Cedaw, por ocasião da avaliação do Relatório Oficial do Brasil a esse comitê.

Instalado em 2007, o Observe foi organizado em Coordenações Regionais: a Agende ficou com a Coordenação da Regional Centro Oeste; a Cepia com a Regional do Sudeste; o Coletivo Feminino Plural com a do Sul; o Gepem com a da região Norte; e o NEIM ficando responsável pela Regional Nordeste. No seu primeiro ano, a Coordenação Nacional do Observe foi compartilhada entre NEIM, Cepia e Agende, tal arranjo mostrando-se, porém, ineficaz para as operações cotidianas. Destarte, a partir de março de 2009, a coordenação nacional concentrou-se apenas no NEIM.

Definiu-se como missão principal do Observe monitorar a implementação e aplicação da Lei Maria da Penha, o que implicou em acompanhar esse processo a partir da coleta, análise e publicização de informações do processo de efetivação da Lei. Nesse 
sentido, no primeiro ano de atividades, o Observatório avançou na organização e fortalecimento da sua rede interna por meio de reuniões, informativos eletrônicos internos e encontros em eventos. Ao mesmo tempo, empenhou-se, também, na articulação com outros órgãos e instituições, a exemplo da iniciativa de diálogo com o Supremo Tribunal de Justiça (STJ), em Brasília/DF, e do estreitamento de relações com instituições locais/regionais da Rede de atenção à mulher em situação de violência.

Logo de início, porém, dois desafios se colocaram para o Consórcio. O primeiro diz respeito à definição da identidade do Observe e, consequentemente, da construção das relações internas ao Consórcio e da relação deste com o Estado e com o movimento social. A questão posta, nesse caso, implicava em definir o que e para quem monitorar. O segundo desafio voltou-se mais propriamente para questões metodológicas - como proceder nesse monitoramento, que indicadores utilizar, ou seja, como monitorar -, questões estas que dependeram, em grande parte, das definições relativas ao primeiro desafio. Trataremos assim da metodologia na próxima seção, voltando-nos aqui para o primeiro desafio, que tem sido, de fato, o maior.

Uma das questões principais levantadas em relação à identidade do Observe centra-se na necessidade de esclarecer o que nos diferencia e o que nos caracteriza enquanto Consórcio, levando em conta que se trata de um grupo com experiências diversas e múltiplas inserções: ONGs feministas, núcleos de estudo e pesquisa vinculado a instituições federais de ensino superior, redes de diferentes organizações (inclusive internacionais, como no caso do Cladem) que não participam diretamente do Consórcio. Nesse sentido, cabe trazer as considerações tecidas durante reunião da Coordenação do Observe por Leila Linhares Barsted, da Cepia, quanto à definição do Observatório como um "conjunto de instituições com olhares diversos e suas especificidades, mas 
com um objetivo comum", qual seja o de produzir um "monitoramento engajado" como parte das lutas feministas. Esse monitoramento daria conta não apenas da aplicação dessa lei, como também de uma cultura jurídica em torno dela, identificando e publicizando as resistências e a aplicação incorreta, mesmo quando "bem-intencionadas". Assim, um dado do Observatório daria conta de uma série de iniciativas e iria além do sentido restrito de monitoramento, abrindo-se para os movimentos de mulheres, estimulando-os a produzir "relatórios sombra".

No entanto, como a própria Leila Barsted acrescentou durante a reunião:

[...] não somos pesquisadoras do movimento, não somos impactadoras do movimento, apesar de sermos parte dele. Tampouco temos o monopólio do monitoramento da Lei Maria da Penha, o que podemos oferecer é uma experiência de observação. Mesmo porque não somos pesquisadoras da SPM, apesar da SPM estar financiando a maior parte de nossas atividades, não somos fiscais da Lei. (Diário de campo)

No entender de Telia Negrão, coordenadora da Rede Feminista de Saúde e também presente nas reuniões do Observe, tal situação é indicativa da identidade ambivalente do Observe, que deve fornecer "produtos" para o Estado, mas manter-se sempre em sinergia com os movimentos, preservando, porém, a sua autonomia em relação a ambos. Para Cecilia Sardenberg, do NEIM e da Coordenação Nacional, isso significa colocar o Observe também em uma situação mediadora entre sociedade civil e Estado - mas, como ressaltou Ana Alice Costa, representante da Redor nas reuniões do Consórcio, com a palavra durante a referida reunião, não simplesmente em relação à SPM. É preciso considerar que as DEAMs, os Juizados, as Casas Abrigo, bem como todos os demais órgãos que formam parte da rede de assistência a mulheres em situação de violência, também são órgãos de Estado, encarregados 
da implementação e aplicação da Lei Maria da Penha. Como construir uma relação com o Estado quando essa rede envolve órgãos e agências de nível municipal, estadual e federal?

Falando do lugar de gestora de políticas de enfrentamento da violência contra mulheres por parte da SPM, Aparecida Gonçalves, presente na reunião do Consórcio realizada em Salvador, em 9 de julho de 2009, destacou que o edital referente à construção de um Observatório da Lei Maria da Penha partiu da necessidade de se ter um instrumento externo ao governo que pudesse contribuir para efetivamente consolidar essa Lei em áreas fundamentais. Ele foi pensado como uma instância de capacitação de avaliação política, a partir do campo teórico feminista, em relação a elementos de aplicabilidade da Lei. O que se esperava, de acordo com Aparecida Gonçalves, tal qual expressado por ela em reunião do Observe, era a construção de um "olhar propositivo", de um instrumento "para olhar o que está acontecendo, fora do vício da máquina do Estado.” Ela prosseguiu acentuando que há "gargalos na Lei Maria da Penha" que demandam esse olhar propositivo para a necessária solução, tal como os impasses no judiciário.

Contudo, para as representantes das entidades que integram o Observe, permanece a questão dos limites desse olhar propositivo. Na verdade, como avaliaram as coordenações regionais e nacional, o Observe não deve ser um órgão de consultoria jurídica em relação à aplicação da Lei, mas apontar como a lei vem sendo aplicada. Isso inclui, por parte do Observe, a construção de uma visão feminista em relação à aplicação da Lei, que possa servir de instrumento tanto para o movimento feminista e sua intervenção em diferentes espaços políticos, como também para o Estado, por exemplo, na consolidação de uma posição em favor das mulheres no judiciário. Daí porque o Observe deve estar em sinergia tanto com os movimentos, quanto com as áreas de atuação da SPM. A ideia de monitorar, nesse caso, envolveria o desenvolvimento de 
processos contínuos de avaliação que pudessem fornecer ferramentas para o Estado e para a sociedade civil - no caso, os movimentos feministas e de mulheres. O Observatório, em si, não é uma ferramenta direta de intervenção na implementação da Lei, mas seus resultados devem provocar a mobilização social para uma intervenção do Estado no sentido do empoderamento das mulheres, particularmente aquelas em situação de violência.

\section{Construindo a metodologia de monitoramento}

O monitoramento da aplicação de uma legislação constitui experiência inédita no país, dada à inexistência de indicadores ou séries históricas de dados que permitam conhecer o desempenho das instituições no combate à violência e os resultados de medidas de enfrentamento da violência doméstica e familiar contra as mulheres no país. Destarte, para as entidades integrantes do Consórcio, a proposta do Observe se destaca de outras iniciativas de monitoramento na medida em que define, como seu "produto mais forte", a construção de uma metodologia de monitoramento da Lei Maria da Penha, com indicadores sólidos, que venham a servir de referência para outras iniciativas de monitoramento da própria Lei e produzir e divulgar conhecimentos na área, gerar informações que subsidiem políticas públicas e ações políticas de prevenção e combate à violência contra as mulheres. Entendem as entidades integrantes do Consórcio que a produção e sistematização de dados quantitativos e qualitativos se constituem como elementos imprescindíveis para avaliação e acompanhamento das políticas públicas.

De fato, o monitoramento de políticas implica no desenvolvimento de um conjunto de atividades visando o acompanhamento, a observação continuada e regular, a coleta e sistematização de informações por meio do emprego de instrumental de pesqui- 
sa adequado aos objetivos definidos, e o controle e checagem das atividades e de sua execução. Entende-se também que o monitoramento de uma política pública deve ser uma atividade-parte de sua execução, de forma que as informações produzidas e sistematizadas possam ser utilizadas para o aprimoramento das metas e alterações de execução, quando necessárias. Nesse sentido, Wanderley e Blanes (2001, p. 174) recomendam que: "Os processos de monitoramento e avaliação exigem a sistematização das informações sendo cada vez mais, imprescindível a existência de banco de dados, de sistemas de informações locais e regionais que alimentem esses processos."

Segundo expressado durante reunião do Observe, Jussara Reis Prá, representante do NIEM/UFRGS no Consórcio e consultora do Observe nas pesquisas quantitativas, todo monitoramento deve partir de um diagnóstico para o qual se torna crucial construir indicadores pertinentes. Assim, o Consórcio elegeu como tarefa prioritária para o primeiro ano de atividades do Observatório desenvolver um processo de construção de indicadores para o monitoramento da Lei Maria da Penha, que resultou na elaboração e aplicação de dois formulários, sendo um instrumento de coleta especialmente pensado para DEAMs, e outro para os Juizados de Violência Doméstica e Familiar contra a Mulher. Esses serviços foram escolhidos pelos papéis estratégicos que desempenham na resolução de casos de violências doméstica e familiar exercidas contra mulheres.

Os dois formulários reúnem indicadores básicos fundamentais para acompanhamento da aplicação da Lei Maria da Penha e foram elaborados coletivamente, contando com a participação de todas as coordenações regionais do Consórcio, além da colaboração de profissionais, como a então juíza titular do Juizado especializado de Cuiabá e a coordenadora das DEAMs do Rio de Janeiro, criando a oportunidade de serem incluídas sugestões de 
quem está na "ponta", prestando atendimento às mulheres, ou lidando diretamente com os serviços que realizam essa tarefa. ${ }^{4}$

Conforme programado, no segundo semestre de 2008, os formulários foram aplicados inicialmente nas capitais sedes das cinco coordenações regionais do Observatório: Belém, Salvador, Brasília, Rio de Janeiro e Porto Alegre. Para além da finalidade de coleta de informações, essa fase de aplicação dos instrumentos de coleta teve por objetivo explorar os limites e possibilidades de obtenção de dados quantitativos e qualitativos considerados estratégicos para o monitoramento da Lei Maria da Penha. Nesse sentido, dentre outras questões, os formulários buscaram obter dados acerca das condições de funcionamento, dos sistemas de registro e sistematização de dados em uso, dos procedimentos adotados, das formas e níveis de articulação com os outros serviços da Rede de atendimento às mulheres em situação de violência e dos principais problemas enfrentados no cumprimento de suas atribuições. Com base em relatórios desse primeiro levantamento, os formulários de coleta foram reformulados e reaplicados em 2009, desta feita em todas as DEAMs e Juizados Especiais de Violência Doméstica e Familiar Contra Mulheres, em funcionamento nas capitais do estados e no Distrito Federal. (GOMES et al., 2010)

Nessa segunda etapa do processo de construção de indicadores e elaboração de um diagnóstico, o preenchimento dos formulários foi realizado durante entrevistas com delegadas de polícia e juízes/as titulares e/ou funcionário/as por ele/as designados. As entrevistas foram conduzidas por 26 pesquisadoras, estudantes de pós-graduação, militantes do movimento de mulheres e feministas, residentes em cada capital, especialmente selecionadas e treinadas para o desenvolvimento das tarefas. Além dos formulá-

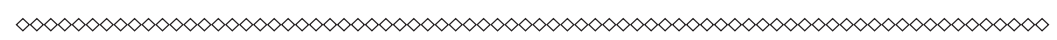

4 Vale destacar que a consolidação final dos indicadores no formato dos dois formulários - um dirigido às DEAMs e outro aos Juizados - foi desenvolvida pela profa. dra. Jussara Prá, do NIEM/ UFRGS, e pela dra. Leila Barsted, do Cepia, respectivamente, graças às suas reconhecidas experiências e conhecimentos na temática em questão. 
rios, as pesquisadoras apresentaram relatos etnográficos em seus diários de campo, consistentes de observações, impressões e comentários que ajudam a compreender não só as características do serviço e do atendimento prestado, mas também a percepção dos funcionários investigados acerca da violência contra as mulheres e a efetividade da Lei Maria da Penha. Reservamos para a próxima seção a discussão desses primeiros resultados, que, ao lado dos dados quantitativos já sistematizados (GOMES et al., 2010), devem se constituir como ferramentas para intervenção, tanto por parte do Estado quanto por parte dos movimentos sociais.

\section{Alguns resultados das pesquisas do Observe}

De modo geral, as pesquisadoras participantes da pesquisa acima referida contaram com a receptividade e colaboração dos funcionários, apesar de em alguns locais identificarem desconfiança, descrédito e/ou desinteresse em relação à pesquisa, seus objetivos e importância. Certamente, foram encontradas pessoas comprometidas com a luta para eliminação da violência contra a mulher, que se mobilizaram para reunir os dados solicitados e não se esquivaram de responder aos questionamentos, em especial com a recomendação expressa das delegadas e juízas que, durante o processo de coleta, procuraram disponibilizar os dados existentes.

As Delegacias funcionam em instalações físicas que não atendem as especificidades para as quais foram criadas: poucas têm sede própria, e o espaço é mal dividido. É comum a ausência de salas de espera individual ou setor de recepção/triagem em que a privacidade das mulheres seja respeitada; às vezes falta água para beber e as instalações sanitárias nem sempre estão limpas; em umas faltam equipamentos como computadores, mesas e cadeiras, e em outras a fiação elétrica antiga oferece risco e provoca frequentemente a suspensão de energia, o que, por sua vez, causa 
a interrupção do atendimento. Além disso, algumas Delegacias estão instaladas em locais de difícil acesso, distantes dos terminais de transporte coletivo e/ou dos bairros com maior incidência de violência contra a mulher.

De acordo com Pasinato (2010a), a inexistência de condições adequadas de trabalho parece ser resultado de um sucateamento de toda a corporação policial nos estados, o que inviabiliza a realização de um trabalho com melhor qualidade, embora isso não possa ser utilizado como justificativa para o mau atendimento prestado às mulheres, nem tampouco deva se constituir em impeditivo para que tenham acesso a seus direitos.

As pesquisadoras visitaram DEAMs cujas instalações físicas se encontram em reforma, outras que estão sendo transferidas para locais mais adequados às demandas das usuárias, assim como algumas que apresentam instalações satisfatórias, com acesso para portadores de deficiência, televisão, salas climatizadas e espaço individualizado de atendimento, o que é interpretado pelas funcionárias como sinal de melhoria e/ou qualidade no atendimento prestado às mulheres. Contudo, há indicadores, não menos importantes, a serem considerados:

$\mathrm{O}$ primeiro diz respeito à morosidade no atendimento, ${ }^{5}$ tanto para efetuar a denúncia como para realização de audiências. Observa-se situações em que, para obter uma simples informação, a pessoa pode ficar mais de duas horas à espera de alguém que a interrogue acerca do motivo de sua ida à DEAM. Numa das capitais, identificou-se uma prática deveras preocupante, a exigência de duas testemunhas que atestem a veracidade dos fatos relatados pela mulher, sem a qual o Boletim de Ocorrência não é registrado, além do agendamento para comparecimento das víti-

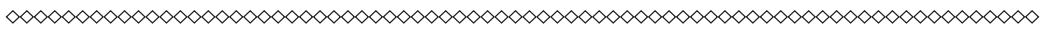

5 A morosidade no atendimento é também apontada por outras pesquisas como uma das queixas feitas pelas mulheres em situação de violência que recorrem às DEAMs. Ver, por exemplo,

Pasinato (2009; 2010a), Sardenberg e colaboradores (2010). 
mas e das pessoas para testemunharem a seu favor, o que incorre na desistência de algumas mulheres por falta de testemunha. Em suma, sob os trâmites burocráticos, oculta-se o descaso e a desimportância atribuída pelos operadores da lei à violência perpetrada contra a mulher.

Durante visita realizada a uma DEAM, por exemplo, identificou-se que uma funcionária sofrera violência doméstica durante anos, mas só denunciara o marido após os colegas de trabalho perceberem as evidências. No entanto, segundo afirma, o processo foi instaurado em julho de 2009, e a audiência com o juiz estava prevista para março de 2010, o que a levou a questionar a pesquisadora acerca da eficiência do Poder Judiciário e, em tom de revolta, verbalizar o desejo de escrever um livro intitulado “Denunciei, e daí? E agora, o que é que eu faço?”. Descrente, mostra-se contrária aos movimentos e campanhas que incentivam as mulheres a denunciarem a violência, uma vez que permanecem desprotegidas, desamparadas.

Suas colocações evidenciam que, se as mudanças produzidas pela Lei Maria da Penha no campo jurídico e político são inegáveis, a mudança cultural ainda parece distante, os valores patriarcais permanecem arraigados nas mentalidades sociais, inclusive entre as(os) juízas(es), que pouco têm se esforçado para instituir, em caráter de urgência, as "medidas de prevenção da violência, de proteção e assistência integral à mulher” (QUEIROZ, 2008, p. 65), direitos conquistados e expressos na lei, sem necessidade de um processo civil ou judicial. Isso porque os valores patriarcais remetem a questão da violência à esfera estritamente privada e naturalizam a desigualdade de poder no seio familiar, ou seja, a violência é classificada como um problema menor, que pode ser resolvido em casa ou com o apoio de psicólogos ou assistentes sociais, de forma a não atrapalhar o bom andamento dos tribunais (DEBERT; GREGORI, 2008), o que se reverte na impunidade dos agressores. 
De fato, uma mulher relatou à pesquisadora que o juiz verbalizou estranhamento ao atendê-la, alegando que costuma emitir sentenças para presos ou bandidos, e não "pessoas de bem" como ela e o companheiro, ou seja, a violência doméstica e familiar contra a mulher não é considerada como um problema a ser resolvido pelo Estado e, portanto, não é passível de penalização/criminalização. Assim, durante a audiência, o juiz tentou persuadi-la a desistir do processo, ${ }^{6}$ argumentando que o filho do casal ficaria traumatizado, e como não conseguiu dissuadi-la, concedeu um prazo de seis meses para que o parceiro mudasse de conduta, proibindo-o de cometer agressões físicas ou verbais no período em questão. Talvez por isso, ao conversarem entre si, as mulheres afirmem: "propaganda é uma coisa, na vida real é outra... A Maria da Penha tá aí... o cabra bate e nada..."

Cabe lembrar que as formulações histórico-culturais acerca da violência doméstica e familiar contra a mulher também influenciam a opinião de operadores da lei sobre o trabalho realizado pelas delegadas e juízas; ou seja, da mesma forma que a violência ainda é tida como algo secundário, menor, as delegadas e juízas se ressentem do menosprezo e da zombaria destiladas pelas(os) colegas, para as(os) quais na DEAM o trabalho é tranquilo, não exige esforço, raciocínio rápido, nem tampouco apresenta desafios, da mesma forma que nos Juizados, já que "a mulher gosta de apa-

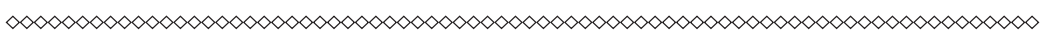

60 artigo 16 da Lei Maria da Penha prevê que a renúncia a uma queixa somente é factível para determinados crimes perante o juiz, em audiência especialmente designada para esse fim. Com essa medida, a lei reforça a impossibilidade de existir mediação de conflitos ou conciliação na esfera policial e judicial (PASINATO, 2010a), o que nos remete a um aspecto apontado por Machado (2010) ao revisitar um texto que escreveu em 2001, quando a Lei n. 9.099 ainda se encontrava em vigência: a imprescindibilidade de revisão no modus operandi do judiciário, tanto naquele período como atualmente. (BRASIL, 1995) Ver, também, as críticas feitas por Debert (2008) às funções assistenciais e conciliatórias exercidas pelas Delegacias das Mulheres (DDMs) - apesar de a mulher ser considerada "sujeito de direitos" -, bem como ao modelo de justiça conciliatória adotado pelos Juizados Especiais Criminais (JECrims), que favorecia a judicialização da família e a despolitização da justiça, ou seja, a conciliação era orquestrada em nome da defesa da família. Observa-se, portanto, que o redesenho das políticas de enfrentamento à violência contra as mulheres, bem como as mudanças institucionais e implantação dos Juizados Especiais, pelo menos no Nordeste, até o presente momento, não conseguiram abolir as velhas práticas de cunho conciliatório. 
nhar” e, portanto, a criminalização não se justifica. Em suma, o trabalho tanto na DEAM como no Juizado é desvalorizado e elevado à condição de não trabalho, portanto, “coisa de mulher”.

Ao que tudo indica, a crescente feminização do judiciário não vem acompanhada de mudanças no que se refere à posição discriminatória em relação às questões de gênero. A magistratura (ainda) permanece como um espaço marcado pelas desigualdades de gênero, e o Tribunal continua um espaço gendrado, masculino. Deste modo, juízas, delegadas e promotoras, para obterem aceitação entre os seus pares, podem negar sua identidade feminina e, na tentativa de conferirem racionalidade e objetividade às sentenças formuladas, assumirem uma postura mais rígida, que associam ao sexo masculino (JUNQUEIRA, 1999), mas também se deixarem seduzir pelo poder opressor, passando a se identificar com as figuras que se percebiam, até então, como dominadoras, o que influencia seu desinteresse em relação aos conflitos domésticos e às reivindicações femininas (CAMPOS, 2010), o que, talvez, seja uma das causas da rotatividade de delegadas em algumas DEAMs.

Além disso, identificou-se que, em algumas capitais, a transferência de servidores do sexo masculino para as DEAMs é usada como mecanismo de punição ou perseguição política pelos gestores, o que contribui para fortalecer sua resistência no que se refere a repensar os valores machistas e sexistas que ainda regem o comportamento de muitos homens e mulheres nordestinos. Não é à toa, portanto, que uma das delegadas entrevistadas, ao se queixar com a pesquisadora sobre a agressividade e descontrole de uma mulher durante o atendimento, não se mostre constrangida quando um agente policial interfere na conversa e verbaliza que, se essa mulher for bonita, pode encaminhar para ele, explicitando claramente suas intenções. Ao contrário, a delegada, conivente, reforça essa postura machista ao afirmar que agentes e motoristas, diante da vulnerabilidade em que se encontram as mulheres, 
recorrem ao discurso de solidariedade e proteção para se aproximarem das mais jovens e bonitas e assediá-las.

Observa-se que a ideologia patriarcal ainda atua como fonte de referência para a constituição identitária do macho nordestino, tanto para as mulheres como para os homens que trabalham nas DEAMs. Afinal, conforme ponderam Queiroz, Lima e Silva (2008), fazem parte da mesma estrutura social e cultural de relações e simbologias de gênero que dão origem à violência contra a mulher, isto é, as concepções e práticas dos(as) profissionais são norteadas por essa estrutura que desvaloriza as mulheres, fazendo com que elas encontrem nas DEAMs desproteção em vez da plena aplicação da Lei.

\section{Considerações finais}

Ao percorrermos o histórico das políticas públicas no Brasil pertinentes ao enfrentamento da violência de gênero contra mulheres, podemos observar que a relação entre os movimentos feministas e de mulheres e o Estado, nesse tocante, avançou bastante nos últimos 30 anos. De fato, de uma total falta de diálogo, durante o período da Ditadura Militar, chegou-se a uma aproximação e até mesmo colaboração, em várias instâncias, entre os movimentos e os órgãos voltados para a promoção do empoderamento de mulheres, como é o caso da SPM, do Governo Federal. Entretanto, é preciso ressaltar, essa relação não se dá sem tensões, como tem sido o caso da relação com o Observe.

De fato, a SPM tem esperado uma atuação mais incisiva do Observe, com intervenções pontuais em relação ao judiciário, por exemplo, enquanto as entidades do Consórcio têm deliberado por produzir um monitoramento baseado em uma metodologia construída com rigor científico, que se desenvolve em um ritmo mais lento - o ritmo das pesquisas - do que foi originalmente pensado 
pela SPM. Isso tem levado a um descompasso nos entendimentos, traduzindo-se em prejuízos no andamento das ações definidas pelo Consórcio responsável para o Observe.

Por outro lado, como se ressaltou anteriormente, o Estado é muito mais amplo e se expressa em diferentes níveis, envolvendo uma série de diferentes órgãos e instituições que lidam, direta ou indiretamente, com ações referentes ao enfrentamento da violência contra mulheres. Nesse tocante, compartilhamos algumas inquietações surgidas na leitura dos cadernos de campo elaborados pelas pesquisadoras da Regional Nordeste do Observe. Apesar dos inegáveis avanços trazidos pela Lei Maria da Penha, e pelos esforços do Governo Federal no sentido da eficácia da sua aplicação, as anotações das pesquisadoras parecem apontar para uma repetição das situações encontradas em capitais investigadas anteriormente: a infraestrutura precária das instalações físicas das DEAMS, situadas em locais de difícil acesso e distantes de serviços públicos; o quadro reduzido e a rotatividade dos servidores, que comprometem a qualidade dos serviços. Embora esses não sejam os indicadores mais preocupantes.

Identifica-se que o burocratismo imprime morosidade ao atendimento, contribuindo para instalar entre as mulheres em situação de violência um sentimento de descrença em relação à aplicabilidade da lei e a certeza de impunidade dos agressores, que é reforçada pela falta de compreensão dos servidores acerca do caráter complexo que envolve a violência contra a mulher e a ausência de uma leitura mais aprofundada sobre seus determinantes.

Constata-se também que a ideologia patriarcal (ainda) presente no imaginário dos(as) servidores(as) torna as mulheres que se dirigem às delegacias, em busca de proteção, alvo do assédio sexual de agentes policiais e motoristas. Eles lhes impõem outra face da violência, com a conivência de algumas delegadas, as quais usam 
o machismo como justificativa e, ao desconhecerem o caráter estrutural da violência, findam por naturalizar tal comportamento.

A violência contra as mulheres, apesar dos avanços legais, ainda se encontra circunscrita ao domínio privado e, por isso, é considerada uma questão secundária e sem importância pelos operadores da lei, que menosprezam o trabalho realizado pelas delegadas e juízas que atuam com conflitos domésticos. Embora não desconheçam a necessidade de intervenção pública diante do crescimento do número de mulheres em situação de violência, ainda entendem que o atendimento não requer uma sentença judicial ou penalização, e sim medidas de aconselhamento e conciliação em prol da preservação da instituição familiar, o que se configura como não trabalho, e sim atenção, exercício da escuta e orientação, coisa de mulher e não de homem.

A capacitação dos profissionais que atuam nos serviços é, sem dúvida, fundamental para modificar as práticas no enfrentamento da violência baseada no gênero. Os Planos Nacionais de Direitos das Mulheres e o Pacto Nacional de Enfrentamento à Violência contra as Mulheres recomendam cursos de capacitação para os profissionais que trabalham em serviços especializados e não especializados no atendimento a mulheres em situação de violência. Inclusive no próprio Pacto estão previstos recursos significativos para a qualificação desses profissionais. Entretanto, as DEAMs, assim como os Juizados, não mantêm dados atualizados acerca dos seus funcionários, especialmente sobre a qualificação e capacitação, o que denota um desinteresse na formação de equipes capazes de compreender e manter atitudes e comportamentos em defesa da igualdade de gênero na sociedade e, por conseguinte, comprometidas com a plena aplicação da Lei.

Cabe ressaltar uma última inquietação: a retração do Estado no tocante à área social, em consonância com a orientação neoliberal, pode comprometer severamente a qualidade e quantida- 
de de programas, projetos e serviços, assim como redirecionar os investimentos públicos, num contexto marcado pela restrição dos gastos sociais, em que a conjunção do discurso burguês com o patriarcal converge para o distanciamento entre os direitos conquistados e sua efetividade, o que pode concorrer para reforçar o descaso em relação às mulheres em situação de violência.

Este artigo trouxe um breve panorama acerca das situações enfrentadas pelas mulheres que recorrem aos serviços de atendimento nas DEAMs e nos Juizados das capitais nordestinas. Certamente, ao passarmos a limpo as anotações das demais capitais e do Distrito Federal, agregaremos novas informações e identificaremos outras situações. Do mesmo modo, a sistematização de informações e estatísticas sobre o funcionamento das instituições e serviços investigados obtidas por meio da aplicação de formulários nas Delegacias e Juizados nas 26 capitais e no Distrito Federal, assim como a realização de estudos de caso nas cinco capitais que sediam o Observe, ${ }^{7}$ certamente originaram outras informações, oferecendo um maior conhecimento acerca dos contextos locais de aplicação da Lei Maria da Penha, bem como dos serviços que atendem as mulheres e os obstáculos que enfrentam para a aplicação da Lei Maria da Penha, inclusive as dificuldades de articulação entre DEAMS e Juizados.

A sistematização dos dados nos possibilitou conhecer as soluções propostas por operadores do Direito e servidores para a realização dos trabalhos, desvendar os possíveis entraves para que a aplicação da Lei Maria da Penha ocorra de forma integral e mapear iniciativas exitosas na aplicação da Lei, contribuindo com recomendações para a melhoria dos serviços em todo o país.

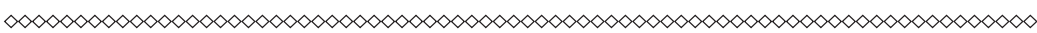

7 Referimo-nos aos relatórios finais das seguintes pesquisas: Condições de aplicação da Lei Maria da Penha nas DEAMs e nos Juizados/Varas de Violência Doméstica e Familiar nas capitais; e Identificando entraves na articulação dos serviços de atendimento às mulheres vítimas de violência doméstica e familiar em cinco capitais. (PASINATO, 2010a, b) 0 Relatório Final de ambas as pesquisas está disponível no site do Observe: www.observe.ufba.br. 
Em suma, esperamos que os resultados parciais discutidos neste artigo instiguem o(a) leitor(a) a conhecer os resultados finais da pesquisa, em âmbito nacional, sobre as Condições de Aplicação da Lei Maria da Penha nas DEAMS e nos Juizados/Varas de Violência Doméstica e Familiar. Por essa razão, recomendamos que para continuar a monitorar a aplicação da Lei Maria da Penha: Observe!

\section{Referências}

AQUINO, S. de. Pathways of women's empowerment through legal strategies: the case of Maria da Penha Law. Brazil. In: PATHWAYS OF WOMEN'S EMPOWERMENT: WHAT ARE WE LEARNING? Cairo, 2009. Anais...Cairo: Pathways of Women's Empowerment Research Programme Consortium, 2009.

BARSTED, L. L. A resposta legislativa à violência contra as mulheres. In: ALMEIDA, S. (Org.). Violência de gênero e políticas públicas. Rio de Janeiro: Editora da UFRJ, 2007. (Série Didáticos).

BLANES, D. Formulação de indicadores de acompanhamento e avaliação de programas sócio-assistenciais. In: ACOSTA, A. R.; VITAL, M. A. F. (Org.). Família: redes, laços e políticas públicas. São Paulo: Cortez, 2005.

BRASIL. II Plano Nacional de Políticas para Mulheres. Brasília: Secretaria Especial de Políticas para as Mulheres, 2008. Disponível em: <http://www.observatoriodegenero.gov.br/eixo/politicas-publicas/ $\mathrm{pnpm} /$ comite-de-monitoramento-do-ii-pnpm/Livro_II_PNPM completo08.10.08.pdf >. Acesso em: 20 abr. 2010.

BRASIL. Decreto n. 4.316, de 30 de julho de 2002. Protocolo Facultativo à Convenção para a Eliminação de Todas as Formas de Discriminação Contra as Mulheres. 2002. Disponível em: <http://www.planalto.gov. br/ccivil_03/decreto/2002/D4316.htm >. Acesso em: 2015.

BRASIL. Lei n. 9.099, de 26 de setembro de 1995. Dispõe sobre os Juizados Especiais Cíveis e Criminais e dá outras providências. Disponível em: <http://www.planalto.gov.br/CCivil_03/leis/L9099. htm>. Acesso em: 20 abr. 2008.

BRASIL. Lei 11.340 de 7 de agosto de 2006. Cria mecanismos para coibir a violência doméstica e familiar contra a mulher, nos termos do $\S 8^{\circ}$ do 
art. 226 da Constituição Federal, da Convenção sobre a Eliminação de Todas as Formas de Discriminação contra as Mulheres. Disponível em: <http://www.planalto.gov.br/ccivil_03/_ato2004-2006/2006/lei/ 111340.htm $>$. Acesso em: 2015.

BRASIL. Pacto nacional pelo enfrentamento à violência contra a mulher. Brasília, DF: Secretaria Especial de Políticas para as Mulheres, 2007.

CAMPOS, C. H. de. Violência de gênero e o novo sujeito do feminismo criminológico. In: ENCONTRO FAZENDO GÊNERO, 9., Florianópolis, 2010. Anais eletrônicos.... Florianópolis: IEF/ UFSC, 2010. Disponível em: <http://www.fazendogenero. ufsc.br/9/resources/anais/1278297085_ARQUIVO_ Violenciadegeneroesujeitonofeminismocriminologico1.pdf $>$. Acesso em: 20 abr. 2008.

DEBERT, G. G.: GREGORI, M. F. Violência e gênero: novas propostas, velhos dilemas. Rev. Bras. Ci. Soc., São Paulo, v. 23, n. 66 fev., 2008. Disponível em: <http://www.scielo.br/pdf/rbcsoc/v23n66/11.pdf >. Acessos em: 23 jun. 2010.

ESPÍRITO SANTO, I. G. Convenção sobre a eliminação de todas as formas de discriminação contra a mulher. Âmbito jurídico, Rio Grande, v. 9 n. 35, dez. 2006. Disponível em: <http://www.ambito-juridico.com.

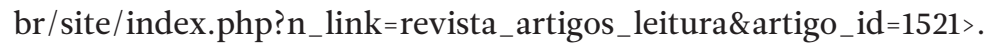
Acessado em: 20 abr. 2008.

GOMES, M. et al. A aplicação da Lei Maria da Penha em foco. Salvador: NEIM/UFBA, 2010.

GOMES, M. et al. Relatório Preliminar do OBSERVE: Observatório de Monitoramento da Aplicação da Lei Maria da Penha. Salvador, 2009. Disponível em: <www.observe.ufba.br >. Acesso em: 2 jun. 2011.

JUNQUEIRA, E. B. A magistratura como um espaço de desigualdade. In: SILVA, D. de P. M. da (Org.). Novos contornos no espaço social: gênero, geração e etnia. Rio de Janeiro: UERJ, NAPE, 1999.

MACHADO, L. Z. Feminismo em movimento. 2. ed. São Paulo: Francis, 2010.

ORGANIZAÇÃO DAS NAÇÕES UNIDAS (ONU). Declaração sobre a eliminação da violência contra as mulheres, 1993. Disponível em: $<$ http://direitoshumanos.gddc.pt/3_4/IIIPAG3_4_7.htm>. Acesso em: 2015. 
ORGANIZAÇÃO DOS ESTADOS AMERICANOS (OEA). Convenção interamericana para prevenir, punir e erradicar a violência contra a mulher - convenção De Belém Do Pará. 1994. Disponível em: <http:// www.cidh.org/Basicos/Portugues/m.Belem.do.Para.htm>. Acesso em: 20 abr. 2008.

PASINATO, W. Condições para aplicação da Lei 11.340/2006 (Lei Maria da Penha) nas Delegacias Especializadas de Atendimento à Mulher (DEAMS) e nos Juizados de Violência Doméstica e Familiar nas capitais e no Distrito Federal: relatório final. Salvador: OBSERVE: Observatório Lei Maria da Penha, Salvador, 2010a. Disponível em: <http://www.observe.ufba.br/_ARQ/Relatorio $\%$ 20apresent $\% 20 \mathrm{e} \% 20$ DEAMs.pdf >. Acesso em: 27 abr. 2015.

PASINATO, W. Estudo de caso juizados especiais de violência doméstica e familiar contra a mulher e a Rede de Serviços para Atendimento de Mulheres em Situação de Violência em Cuiabá, Mato Grosso: relatório final. São Paulo: OBSERVE: Observatório Lei Maria da Penha, 2009. Disponível em: <http://www.observe.ufba.br/_ARQ/ estudodecaso.pdf>. Acesso em: 27 abr. 2015.

PASINATO, W. Identificando entraves na articulação dos serviços de atendimento às mulheres vítimas de violência doméstica e familiar em cinco capitais: relatório final. Salvador: OBSERVE: Observatório Lei Maria da Penha, 2010b. Disponível em: <http://www.observe.ufba. $\mathrm{br} /$ ARQ/relatorio_final_redes $\% 5 \mathrm{B1} \% 5 \mathrm{D} \% 20 \% 281 \% 29 . \mathrm{pdf}>$. Acesso em: 27 abr. 2015.

PASINATO, W. Violência contra a mulher no Brasil: acesso à Justiça e construção da cidadania de gênero. In: CONGRESSO LUSO-AFROBRASILEIRO DE CIÊNCIAS SOCIAIS, 8, 2004, Coimbra. Anais eletrônicos... Coimbra: Universidade de Coimbra: 2004. p. 1-18. Disponível em: <http://www.ces.uc.pt/lab2004/inscricao/pdfs/ painel12/WaniaPasinatoIzumino.pdf>. Acesso em: 2012.

QUEIROZ, F. M. de. Não se rima amor e dor: cenas cotidianas de violência contra a mulher. Mossoró, RN: UERN, 2008.

QUEIROZ, F. M. de; LIMA, M. G.; SILVA, R. W. A Lei Maria da Penha como mecanismo de combate à violência contra a mulher. In: ENCONTRO NACIONAL DE PESQUISADORES EM SERVIÇO SOCIAL, 9., 2008. Anais... São Luís: ABEPSS, 2008. (CD-Rom). 
RAGO, M. Os feminismos no Brasil: dos "anos de chumbo" à era global. Labrys, n. 3, jan./ jul., 2003. Disponível em: <http://www.labrys.net. br/labrys3/web/bras/marga1.htm>. Acesso em: 10 ago. 2015.

SARDENBERG, C. et al. Domestic violence and women's access to justice in Brazil. Salvador: Observatório da Lei Maria da Penha, 2010. Disponível em: <http: //www.observe.ufba.br/_ARQ/UNIFEM $\% 20$ access $\% 20$ to $\%$ 20justice $\% 20$ report $\% 20$ sept $\% 2030 \% 20 \% 282 \% 29$.pdf $>$. Acesso em: 27 abr. 2015.

TAVARES, M.; SARDENBERG, C.; GOMES, M. Feminismo, estado e políticas de enfrentamento à violência contra mulheres: monitorando a Lei Maria da Penha. Labrys, n. especial, jan./jun., 2012. Disponível em: <http://www.tanianavarroswain.com.br/labrys/labrys20/bresil/ lei \%20MP.htm>. Acesso em: 2012.

WANDERLEY, M. B.; BLANES, D. Monitorando a implantação de um programa social. In: BARREIRA, M. C. R. N.; CARVALHO, M. do C. (Org.) Tendências e perspectivas na avaliação de políticas e programas sociais. São Paulo: PUC-SP, 2001. 


\section{ANÁLISE DAS DECISÕES DO SUPERIOR TRIBUNAL DE JUSTIÇA NOS CASOS DE VIOLÊNCIA DOMÉSTICA E FAMILIAR CONTRA A MULHER}

Maria Terezinha Nunes

Maria Gabriela Hita

\section{Introdução}

Por ocasião do XVI Simpósio Baiano de Pesquisadoras/es sobre Mulheres e Relações de Gênero e do I Seminário Nacional Políticas de Enfrentamento à Violência contra as Mulheres, realizados pelo Núcleo de Estudos Interdisciplinares sobre a Mulher da Universidade Federal da Bahia (NEIM/UFBA) em novembro de 2010, sobre o tema "A violência de gênero e suas várias faces", foi apresentada uma versão preliminar de dados empíricos da pesquisa de mestrado, então em andamento, no Programa de PósGraduação (PPG) do NEIM/UFBA. Trata-se de estudo voltado ao conhecimento das práticas judiciárias nos casos de violência do- 
méstica e familiar contra a mulher nos primeiros quatro anos de aplicação da Lei Maria da Penha.

A Lei n. 11.340, de 2006, destinada a coibir a violência doméstica e familiar contra a mulher e denominada, após sua publicação, Lei Maria da Penha (LMP), ${ }^{1}$ foi um produto resultante de intenso trabalho realizado por advogadas feministas de diversas organizações não governamentais, que, avaliando a aplicação da legislação vigente aos casos de violência doméstica contra a mulher, chegaram à conclusão de que era necessária uma lei especial, de natureza interdisciplinar, que levasse em conta a perspectiva de gênero e tivesse como foco principal a proteção da mulher em situação de violência. (BRASIL, 2006; BARSTED, 2003) Em um segundo momento da elaboração dessa Lei e tendo como ponto de partida os estudos iniciais promovidos por grupos feministas, foi ampliado o debate no âmbito nacional, passando a envolver setores diferenciados do executivo, legislativo, judiciário, além da sociedade civil, para que finalmente fosse aprovada. Com essa Lei e a nova concepção de atendimento às mulheres nela inserida, espera-se reverter, com mais eficácia, o quadro de grave violação dos direitos humanos das mulheres, evidenciado nos diversos estudos sobre o tema. ${ }^{2}$

As inovações introduzidas pela Lei Maria da Penha nas práticas judiciárias revelam a importância do atendimento às mulheres em situação de violência nessa esfera, mas também deixa patente a insuficiência do Judiciário em resolver sozinho o caso concreto de violência em toda sua extensão e complexidade. São exemplos de algumas dessas inovações a criação de Juizados de Violência Doméstica e Familiar contra a Mulher, com competência mista de natureza cível e criminal; a prorrogação da competência das Varas Criminais para também analisarem esses casos, enquanto

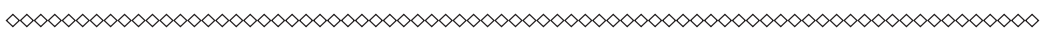

1 Adiante, apenas Lei de Violência Doméstica contra a Mulher ou simplesmente LMP.

2 Sobre a elaboração da proposta inicial de uma Lei de Violência contra a Mulher, ver Barsted (2001; 2003), Barsted e Lavigne (2002), OBSERVE (2009, 2010). 
não instalados os Juizados de Violência Doméstica e Familiar contra a Mulher; e a criação de equipe multidisciplinar - composta de profissionais das áreas psicossocial, jurídica e de saúde - para atuarem nesses Juizados/Varas Criminais. Destaca-se na Lei as medidas protetivas com a finalidade de resguardar a integridade física e psicológica da mulher em situação de violência enquanto perdurar o risco para a ofendida, a exemplo de suspensão da posse ou restrição do porte de armas; afastamento do lar, domicílio ou local de convivência com a ofendida; proibição de aproximação e de contato com a ofendida e seus familiares, além de demandas de proteção relativas à regulamentação de visitas aos filhos, decretação de alimentos, separação, entre outras, considerando que, por vezes, são o foco da conduta violenta contra a mulher. De modo geral, essa Lei veio para instrumentalizar os operadores do Direito ${ }^{3}$ para uma prestação jurisdicional mais célere e interdisciplinar aos casos de violência doméstica contra a mulher.

Esse novo mecanismo legal preenche lacunas e deficiências importantes detectadas por segmentos feministas, desde os anos 1980, nos serviços de atendimento às mulheres em situação de violência e nas distintas experiências dos centros de atendimento SOS-Mulher, das Delegacias Especiais de Atendimento às Mulheres (DEAMs), e nos Juizados Especiais Criminais (JECrims), criados pela Lei n. 9.099, de $1995 .{ }^{4}$ Entretanto, mesmo contan-

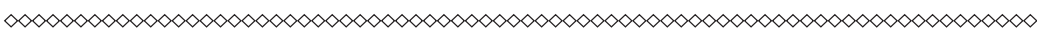

3 Nesta pesquisa, definem-se operadores do Direito, restritivamente, para alcançar somente magistrados e representantes do Ministério Público. No singular, para significar apenas os juízes.

4 A Lei n. 9.099 foi criada com o objetivo de regulamentar o artigo 98 da Constituição Federal de 1988, que estabeleceu a obrigação de os estados criarem Juizados Especiais para a conciliação, julgamento e a execução de causas cíveis de menor complexidade e as infrações de menor potencial ofensivo. De acordo com a Lei n. 9.099, as infrações penais de menor potencial ofensivo seriam as contravenções penais e os crimes a que a lei comine pena máxima não superior a um ano, posteriormente alterada para dois anos. (BRASIL, 1995) Verifica-se, portanto, que essa lei utilizou um critério objetivo, geral, com base na pena máxima fixada para definir infração penal de menor potencial ofensivo. Assim, a maioria dos delitos comumente praticados contra as mulheres, como a ameaça, lesão corporal, injúria e vias de fato, passou para o âmbito dos JECrims. Diversos estudos deram conta de que, no âmbito dos JECrims, os delitos praticados contra as mulheres tinham o mesmo tratamento de outros delitos. Os operadores do Direito não atentaram para as peculiaridades presentes no contexto da violência doméstica contra a mulher, como as relações assimétricas de gênero, o convívio próximo com o ofensor, a reincidência, entre outros. 
do com amplo debate em seu processo de elaboração, a Lei Maria da Penha foi recebida com imensa resistência, em especial pelos operadores do Direito, em sua aplicação aos casos concretos de violência doméstica contra a mulher que chegavam ao judiciário. (BRASIL, 1995)

Diante disso, interessou a este estudo conhecer as práticas judiciárias nos casos de violência doméstica contra a mulher, ou seja, a forma pela qual os operadores do Direito, notadamente os magistrados, desde a aprovação da Lei Maria da Penha, estão conduzindo esses casos. Com essa finalidade, buscou-se analisar as decisões do Superior Tribunal de Justiça (STJ) nos primeiros quatro anos de vigência da Lei, com o objetivo de detectar o tipo de resposta dada pelo Tribunal a esses casos, fazendo emergir alguns dos entraves na aplicação da Lei Maria da Penha e os reflexos dessas decisões para as mulheres em situação de violência.

O recorte empírico sobre as decisões do STJ levou em conta, entre outros fatores, que esse órgão passou a protagonizar papel importante na interpretação da Lei Maria da Penha, em especial pela competência constitucional em dirimir conflitos de interpretação entre duas leis federais, a Lei n. 9.099/95 e a Lei n. 11.340/2006. Embora a Lei Maria da Penha tenha afastado, expressamente, pelo seu artigo 41, a aplicação da Lei n. 9.099/95, questiona-se, nas práticas judiciárias, a possibilidade de aplicação de alguns de seus institutos aos casos concretos de violência doméstica contra a mulher. (BRASIL, 1995; 2006)

Tem-se por pressuposto que o número de processos de violência doméstica contra a mulher que chega ao STJ revela uma tendência das principais questões discutidas a respeito da apli-

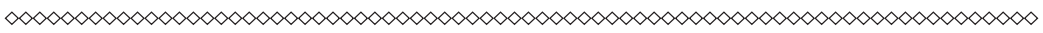

5 Cabe esclarecer que a Lei n. 9.099 não era aplicada a todos os casos de violência domésticofamiliar contra a mulher, porém, a partir de estudos, constatou-se que aproximadamente $80 \%$ dos casos apreciados nos JECrims referiam-se à violência doméstica (BRASIL, 1995; BARSTED, 2001) e, ainda, que vigoravam nas práticas desses juizados a insistência dos operadores do Direito para a conciliação e a desistência da representação pela mulher ofendida, resultando em arquivamento a maioria desses casos. (CAMPOS, 2001; OLIVEIRA, 2006) 
cação da Lei Maria da Penha nas demais instâncias judiciárias do país. Pelo sistema de informatização da justiça ou mesmo pela repercussão na imprensa, suas decisões chegam com rapidez aos mais recônditos cantos do país. Assim, a cada decisão, seja individual (monocrática) ou coletiva (acórdão), o STJ vem repassando seu reposicionamento às demais instâncias ou moldando a interpretação dessa nova lei de enfrentamento da violência doméstica contra a mulher. No mesmo sentido de Pandjiarjian (2002, p. 7), entende-se, nesta pesquisa, que o Judiciário, ao explicar as leis, constrói relações sociais.

Optou-se pela análise das decisões definitivas, de mérito, ${ }^{6}$ coletadas no repositório de jurisprudência do STJ, na forma detalhada abaixo. Para análise dos resultados obtidos, foi utilizada a análise prática-documental, criando-se um instrumento de pesquisa específico, onde foram anotados os dados relativos às características dos processos aos quais se referiam as decisões e os argumentos utilizados no juízo de origem e por ministros(as) do STJ para fundamentar a decisão. Nos casos em que as informações constantes das decisões eram muito sucintas, foi feita uma tentativa de complementação dos dados, mediante acesso direto ao processo, no Setor de Arquivo do Tribunal e no banco de processos digitalizados do Tribunal.

$\mathrm{Na}$ análise das decisões, foi utilizada a abordagem quantitativa sobre as características dos processos e a qualitativa para elucidar principais tipos de argumentos das decisões. Desde uma perspectiva de gênero e relacional, as discussões dos resultados se apoiaram no conceito de gênero formulado por Scott (1995), em que gênero é concebido como um elemento constitutivo das relações sociais e como uma forma primária para significar as relações de poder.

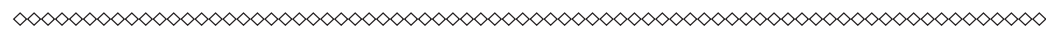

6 A análise de mérito envolve uma maior argumentação por ministros (as) decidindo sobre o pedido. 


\section{A coleta dos dados}

O processo de coleta das decisões do STJ resultou na obtenção de 718 documentos, selecionados após consultas à página virtual do STJ e à Seção de Jurisprudência do Tribunal, com a finalidade de identificar o melhor critério que possibilitasse alcançar o maior número de processos sobre o tema em estudo. Esse foi o primeiro passo, uma vez que interessaram a esta pesquisa as decisões finais e de mérito do STJ nos casos de violência doméstica contra a mulher.

O critério final ficou assim definido:

lei @ ref="11340" ou (lei prox5 ("11340"\$ ou “11.340"\$)) ou (lei adj2 maria adj2 penha) ou violencia prox5 (domestica ou familia\$) e (5t.org. ou 6t.org. ou 3s.org.)

Por opção da pesquisa, a busca de decisões foi realizada apenas na quinta e sexta turma e na Terceira Seção do STJ, ante a constatação de que a grande maioria dos casos de violência doméstica contra a mulher estava sendo julgada nesses órgãos de matéria penal. Dessa forma, foi possível obter 70 decisões coletivas (acórdãos) e 648 decisões individuais (monocráticas).

Não obstante o rigor na busca do mais adequado critério de pesquisa, foram identificados processos estranhos ao tema. Em alguns casos, devido a erro de digitação: em vez de ser digitado Lei n. 11.430/2006, foi digitado Lei n. $11.340 .^{7}$ O segundo filtro, aplicado à lista de documentos, retirou as decisões liminares, ou seja, aquelas sem a respectiva decisão final de mérito, as que homologaram desistência, que não conheceram, negaram seguimento ou que julgaram "prejudicado" o pedido. Após essas exclusões, chegou-se a 183 documentos. (BRASIL, 2006)

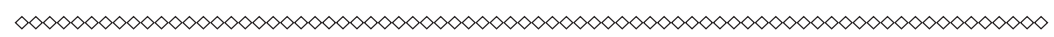

7 Apesar dessas incongruências, optou-se pela manutenção do critério, pois, segundo informação na Seção de Pesquisa de Jurisprudência do Tribunal, esse critério possibilitaria agregar mais documentos que só mencionassem a Lei pelo número e não fizessem qualquer referência aos termos "violência doméstica" ou "Lei Maria da Penha". 
Essas decisões, após serem organizadas, tendo em vista a questão central discutida, evidenciaram três grandes eixos de discussão dominando os debates na aplicação da Lei Maria da Penha no judiciário. O primeiro eixo referia-se a questionamentos acerca da competência, em geral, dois ou mais juízes declarando-se incompetentes para o caso concreto de violência doméstica contra a mulher; o segundo trouxe questões acerca de medidas protetivas de urgência de natureza penal levadas pelos ofensores ao STJ, buscando sua revogação; e o terceiro evidenciou as discussões sobre o instituto da representação ${ }^{8}$ nos delitos de lesão corporal decorrentes de violência doméstica contra a mulher no ambiente doméstico-familiar ou nas relações afetivas. Nesse último eixo ficou evidenciada a polarização do debate entre Ministério Público e Defensoria Pública, sendo que aquele afirmava a natureza incondicionada desse tipo de delito, ${ }^{9}$ ou seja, independeria da vontade da mulher para que a ação penal fosse instaurada, e a Defensoria Pública, representando os ofensores, afirmava o contrário, ou seja, a natureza condicionada e dependente de representação para que a ação penal tenha prosseguimento.

A identificação desses três eixos redirecionou o olhar da pesquisa para questões mais específicas de aplicação da LMP, pois revelam como os casos de violência doméstica contra a mulher estão

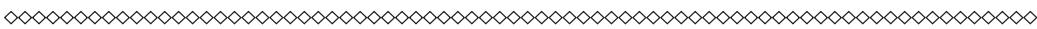

8 No âmbito jurídico, a representação é a "comunicação de um crime à autoridade competente, solicitando providências para apurá-lo e punir o seu autor, devendo ser feita pela vítima ou pelo seu representante legal". (NUCCl, 2009, p. 134) No caso de violência doméstica contra a mulher, significa que a manifestação da ofendida é condição essencial para que o poder público inicie o processo de investigação e punição da prática delituosa. As ações penais que dependem de representação são denominadas de ação penal pública condicionada à representação e expressamente definidas no Código Penal, tendo em vista que a regra geral é a ação penal pública incondicionada, ou seja, aquela em que o poder público inicia logo a investigação ao receber a notícia da ocorrência de um delito, pela ofendida ou qualquer outra pessoa. Cabe informar, a título de atualização dessa discussão, que o Supremo Tribunal Federal, recentemente, julgando a Ação Direta de Inconstitucionalidade n. 4424, declarou que a ação penal para apuração do delito de lesão corporal quando praticado contra a mulher, no contexto doméstico-familiar, tem a natureza de pública incondicionada.

9 Neste artigo, será usado, preferencialmente, o termo "delito(s)" para referir-se a "crime" e/ou "contravenção". 
sendo apreciados e julgados no STJ e demais instâncias judiciárias. Assim, tendo por parâmetro a questão central discutida, foi obtida a seleção final de 166 decisões para serem efetivamente analisadas, as quais foram distribuídas da seguinte forma:

1. o Grupo I, contando com 109 decisões, ${ }^{10}$ tratou de questões relacionadas ao órgão julgador competente para os casos de violência doméstica contra a mulher em Processos de Conflito de Competência;

2. o Grupo II, contando com 24 decisões em habeas corpus, trouxe discussões a respeito da concessão ou revogação de medidas protetivas;

3. o Grupo III, com 33 decisões em recurso especial e habeas corpus, trouxe questões referentes ao instituto da representação.

Para fins deste sucinto artigo, a análise a seguir se deterá apenas nas decisões do Grupo I acerca do órgão competente, para apreciar e julgar os casos de violência doméstica contra a mulher, relatando seus principais resultados.

\section{As práticas judiciárias a partir da análise das decisões do Grupo I}

A Lei Maria da Penha prevê que Juizados Especiais de Violência Doméstica e Familiar sejam criados pelos estados e, enquanto es-

$\infty<\infty<\infty<\infty<\infty<\infty<\infty<\infty<\infty<\infty<\infty<\infty<\infty<\infty<\infty<\infty<\infty<\infty<\infty<\infty<\infty<\infty<\infty<\infty<\infty<\infty<\infty<\infty<\infty<\infty<\infty<\infty<\infty$

10 Constatou-se que a maioria de Conflitos de Competência (107 casos) tinha por base a declaração de incompetência dos juízes, gerando o conflito negativo de jurisdição, mas também pode ocorrer de a parte interessada ou o Ministério Público suscitarem a incompetência do juiz em exceção própria. (BRASIL, 1941, Art. 115) No levantamento dos dados, detectou-se a existência de dois habeas corpus discutindo competência, pelo Ministério Público, porém, não serão integrados a este Grupo, já que, neste estudo, são privilegiadas as discussões suscitadas pelos juízes. 
ses Juizados não forem instalados, serão competentes as Varas Criminais, nos termos definidos nos artigos 14 e 33 dessa lei. ${ }^{11}$

À semelhança do que ocorreu na década de 1980, quando as feministas alertaram para as peculiaridades do crime de violência contra a mulher e pressionaram pela criação das Delegacias Especiais, a criação de um Juizado Especial de Violência Doméstica e Familiar parece ser uma "aposta" feminista para que esses delitos sejam tratados de forma diferenciada e única, dada a complexidade do tema, que envolve relações de gênero, de afetividade e assimetrias de poder.

O objetivo da criação desses Juizados é a concentração de atos em um só órgão judiciário, onde a mulher em situação de violência possa demandar pedidos diversos que alcancem variadas áreas do Direito: cível, penal, trabalhista, administrativa e outras, requeridas como suporte material a ser fornecido pela Justiça, e, assim, sair da violência recente ou do ciclo de violência em que se encontre.

Logo após ser publicada a Lei Maria da Penha, diversos Juizados foram criados, em especial nas capitais do país. (OBSERVE, 2010) No entanto, a grande maioria das cidades brasileiras não conta ainda com esse órgão especializado. Pensando nas dificuldades de implantação desses Juizados, a Lei determinou que as Varas Criminais julgassem os processos de violência doméstica e acumulassem a competência cível na apreciação desses casos. Ao designar as Varas Criminais competentes para as causas de vio-

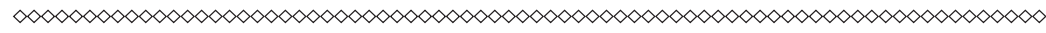

11 Lei n. 11.340, art. 14: "Os Juizados de Violência Doméstica e Familiar contra a Mulher, órgãos da Justiça Ordinária com competência cível e criminal, poderão ser criados pela União, no Distrito Federal e nos Territórios, e pelos Estados, para o processo, o julgamento e a execução das causas decorrentes da prática de violência doméstica e familiar contra a mulher"; art. 33: "Enquanto não estruturados os Juizados de Violência Doméstica e Familiar contra a Mulher, as varas criminais acumularão as competências cível e criminal para conhecer e julgar as causas decorrentes da prática de violência doméstica e familiar contra a mulher, observadas as previsões do Título IV desta Lei, subsidiada pela legislação processual pertinente. Parágrafo único. Será garantido o direito de preferência, nas varas criminais, para o processo e o julgamento das causas referidas no caput." (BRASIL, 2006, grifo nosso) 
lência doméstica contra a mulher, a Lei deixa clara a intenção de retomar a prática da violência doméstica como crime, não mais podendo ser considerada como algo de menor importância a ser resolvida pelo consenso, nos JECrims, sob as regras da Lei $\mathrm{n}$. 9.099. (BRASIL, 1995)

Apesar dessas determinações, processos de violência doméstica contra a mulher estão sendo encaminhados para os JECrims, onde a tônica procedimental destoa dos procedimentos estipulados pela Lei Maria da Penha. Conforme resultados da pesquisa, que serão mostrados mais adiante, alguns juízes têm se recusado a apreciar as ações de violência doméstica contra a mulher, instaurando o Conflito de Competência. Nesse caso, nenhuma ação que demande a atuação do juiz é tomada enquanto não se define quem vai julgar o caso concreto de violência levado ao judiciário. É importante considerar que as medidas iniciais são de caráter emergencial, especialmente se houver pedidos de concessão de medidas protetivas formulados pelas mulheres, visando resguardar sua integridade física e psicológica.

De acordo com a LMP, o pedido de medidas protetivas requerido na delegacia deve ser imediatamente encaminhado ao poder judiciário para apreciação do juiz (artigos 12 e 18). Sendo assim, a "demora" ${ }^{12}$ resultante da negativa dos juízes em julgar esses processos, seja nos Juizados de Violência Doméstica e Familiar contra a Mulher, seja nas Varas Criminais, fragiliza esse serviço de atendimento no âmbito do judiciário, essencial à rede de apoio às mulheres em situação de violência. (BRASIL, 2006) ${ }^{13}$

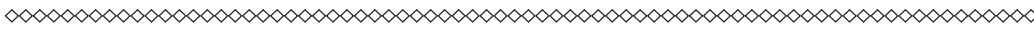

12 Pela escassez de dados nas decisões do STJ, não foi possível identificar o lapso temporal entre a data de ocorrência da violência e a data de apreciação final do Conflito de Competência. Parte desse tempo pode ser aferido a partir da data de autuação do Conflito no STJ e da publicação da decisão. Tomando por base apenas as decisões coletivas (acórdãos), constatou-se uma demora de cerca de seis a oito meses, em média, para a resolução do Conflito nesse Tribunal.

Conforme será mostrado mais adiante, o dado referente a pedidos de medidas protetivas formulados pelas mulheres revelou-se de difícil obtenção, pois não consta essa informação na maioria das decisões do STJ. Contudo, essa parece ser uma questão presente nos processos de violência doméstica, pois foram identificados alguns casos em que o STJ decidiu, de imediato, 
Normalmente, os Conflitos de Competência são resolvidos nos respectivos Tribunais de Justiça, como seria, por exemplo, o caso de Conflito entre duas Varas Criminais, entre uma Vara Cível e outra Criminal, ou ainda entre dois Juizados de Violência Doméstica e Familiar, localizados no mesmo estado. Até meados de 2009, quando o conflito de jurisdição incluía um JECrim, o processo seguia para o Superior Tribunal de Justiça, tendo por fundamento a interpretação consubstanciada na Súmula do STJ n. 348, de 4 de junho de 2008 (BRASIL, 2008), e a decisão do Supremo Tribunal Federal, adotada por analogia no STJ, em processo que dirime controvérsia a respeito de quem vai julgar, na área federal, os conflitos envolvendo Juízo Comum e Especial. Não obstante essas variações interpretativas, pode-se afirmar que coube ao STJ dirimir os Conflitos de Competência mais sensíveis à aplicação da Lei Maria da Penha, considerando que essa Lei busca afastar totalmente as regras da Lei n. 9.099 (BRASIL, 1995), e, portanto, os JECrims dos casos de violência doméstica. ${ }^{14}$

\section{As características dos processos}

Os dados relativos às características dos processos possibilitaram conhecer o tipo de processo, ano de publicação e origem, medida protetiva (se adotada ou não), tipo de delito, pessoa ofendida, e tipo de decisão.

Inicialmente, constatou-se que todas as decisões do Grupo I, sem exceção, referiam-se a Conflito Negativo de Competência.

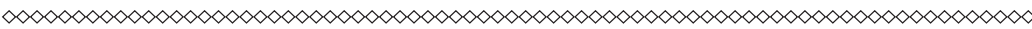

mas provisoriamente, quem era o Juízo Competente para a causa, para expedir as medidas protetivas requeridas no processo.

14 A competência do Superior Tribunal de Justiça para análise de Conflitos envolvendo JECrims firmou-se a partir da Súmula/STJ n. 348, de 4 de junho de 2008 (BRASIL, 2008), estendendose essa interpretação aos casos de violência doméstica contra a mulher. Posteriormente, essa Súmula foi cancelada no STJ, resultando, para os casos de violência doméstica contra a mulher, na remessa dos Conflitos de Competência para análise dos Tribunais de Justiça dos respectivos estados. Dessa forma, torna-se importante conhecer como esses casos estão sendo resolvidos nessa instância judiciária. 
Significa dizer que nenhum juiz julgou-se competente para a apreciação do caso concreto de violência doméstica contra a mulher que chegou às suas mãos. De modo geral, o primeiro juiz, ao receber a causa, declarou-se incompetente e, por essa razão, encaminhou o caso a outro juiz; este, por sua vez, declarando-se também incompetente, instaura o Conflito e o encaminha à Instância Superior para resolução. Verificou-se que foram, predominantemente, as Varas Criminais a enviar o caso para os JECrims, indicando uma aparente rejeição à Lei Maria da Penha pelas Varas Criminais, justamente o órgão judiciário eleito pela Lei para os casos de violência doméstica contra a mulher, enquanto não instalados os Juizados específicos.

Em relação ao ano de publicação, verificou-se a intensa concentração de decisões no ano de 2009 (95 casos), ${ }^{15}$ bem como uma incidência majoritária de casos originários de Minas Gerais (98 casos). Analisando a procedência dos casos de Minas Gerais, não se observou uma disseminação de Conflitos de Competência por todo o estado, mas uma recidiva insistente de algumas Varas Criminais na utilização desse recurso jurídico, que resulta em morosidade na apreciação do caso concreto de violência contra a mulher levado ao Judiciário.

Cabe destacar que nos próprios Juizados de Violência Doméstica contra a Mulher, criados especialmente para aplicar a Lei Maria da Penha, pairam dúvidas sobre questões relativas à competência. É o caso de alguns Juizados do estado do Amazonas que se dizem incompetentes para a causa, quando não consta pedido de concessão de medidas protetivas pelas mulheres em situação de violência. Esses casos seguem para os JECrims, sob a

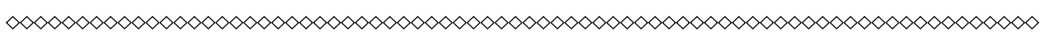

15 Conforme consta na nota anterior, as divergências de interpretação acerca de quem vai dirimir os Conflitos de Competência envolvendo os JECrims, resultando na edição da Súmula STJ n. $348 / 2008$ e no seu cancelamento em março de 2010 , podem explicar, em parte, a intensa concentração de casos no ano de 2009. 
alegação de que a Resolução do Tribunal de Justiça do Estado do Amazonas assim o estabeleceu. ${ }^{16}$

Nota-se, nessas duas situações, o apelo para que os JECrims continuem a atuar nesses casos e a grande dificuldade de absorção do novo paradigma de atenção ditado pela Lei Maria da Penha.

Pode-se dizer que um dos efeitos mais indesejáveis da instauração do Conflito Negativo de Competência para as mulheres em situação de violência é a protelação na análise dos pedidos de medidas protetivas, porventura existentes, pois compromete a celeridade na tomada de decisão, colocando em risco a segurança dessas mulheres, ou em caso de inexistência de pedido de medidas protetivas, retarda a apreciação e julgamento da prática delituosa. Contudo, não foi possível verificar o alcance desse efeito para as mulheres em situação de violência em função do grande número de casos "não informados" no rol de decisões analisadas. ${ }^{17}$

Notou-se, entretanto, que as discussões sobre medidas protetivas estavam presentes nessas ações, conforme mostra o seguinte julgado:

[...] Foram distribuídos neste Juizado Especial Criminal da Comarca de Conselheiro Lafaiete/MG, remetidos pelo i.Juízo da $1^{\text {a. }}$ Vara Criminal desta Comarca, os autos de expediente solicitando medidas protetivas de urgência em favor de L.F.S, nos termos da Lei $n^{\circ} 11.340 / 2006,[\ldots]$. De se acrescentar, por fim, que os autos versam apenas e exclusivamente sobre medidas protetivas na Lei ${ }^{\circ} 11.340 / 2006$ e, se o i. Magistrado da $1^{\text {a. }}$. Vara Criminal entendeu não se tratar de hipótese de 'violência doméstica' (sic),

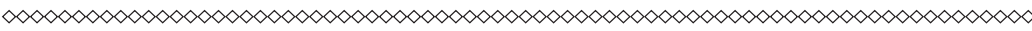

16 Artigo $2^{\circ}$ da Resolução n. 16 de 2007 do Tribunal de Justiça. (AMAZONAS, 2007)

17 Em diversas decisões, a exposição sucinta dos fatos impossibilitou identificar a existência de pedidos de medidas protetivas formulados pelas mulheres. Realizou-se um esforço para a obtenção desses dados, utilizando-se da consulta eletrônica aos processos já digitalizados (poucos casos) e também da consulta à página virtual do Tribunal do Estado onde ocorreu a violência (poucas Varas/Juizados disponibilizam o conteúdo das audiências, mesmo não sendo caso de segredo de justiça). Apesar desses recursos, ainda foi grande o número de casos em que não foi possível identificar a existência de medidas protetivas e o vínculo existente entre as partes. Assim, torna-se importante, em pesquisa específica, conhecer a realidade de pedidos de medidas protetivas formulados pelas mulheres e a decisão dos juízes nesses pedidos. 
a solução para o caso seria o indeferimento dos pedidos formulados e não a remessa dos autos a este Juízo, uma vez que não se trata de notitia criminis [...]. (BRASIL, 2009)

Consta, nesse grupo de decisões, a majoritária ocorrência de delitos de lesão corporal (26), ameaça (42) e vias de fato (41), os quais eram, indubitavelmente, considerados de menor potencial ofensivo em razão da pena fixada, sob a vigência da Lei n. 9.099. (BRASIL, 1995) Percebe-se, portanto, uma maior resistência nos Juízos de origem à nova leitura dada pela Lei Maria da Penha, que classifica esses delitos como de natureza grave, em função de suas peculiaridades. Conforme será mostrado nas argumentações, mesmo com a previsão das condutas proibidas pela Lei Maria da Penha, os operadores do Direito relutam em classificá-las como crimes e uma das formas de violação dos direitos humanos das mulheres.

Foi possível observar que os delitos ditos mais graves, como homicídio ${ }^{18}$ e estupro, pela baixa ocorrência (1 caso), não suscitam dúvidas no Juízo de origem quanto a sua competência, pois, anteriormente à LMP, esses delitos já eram de competência das Varas Criminais/Tribunal do Júri.

Predominaram nesse grupo de decisões casos envolvendo relações entre ex-companheiros (26), companheiros (17), ex-namorados (14), entre outros, ${ }^{19}$ em que o homem é o ofensor. Foram detectados apenas seis casos em que a mulher é a parte ofensora. ${ }^{20}$ Esses dados vêm ao encontro dos estudos que apontam a mulher como a mais atingida pela violência nas relações doméstico-familiares ou afetivas. (AZEVEDO, 1985; GREGORI, 1993; MACHADO;

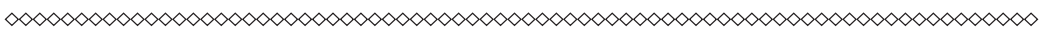

0 caso de homicídio, registrado nesse grupo, refere-se a Conflito de Competência entre o Juizado de Violência Doméstica e o Tribunal de Júri, quanto à fase de instrução. Cabendo o julgamento ao Tribunal de Júri, questiona-se sobre a realização da instrução pelo Juizado de Violência Doméstica contra a Mulher.

19 Detectou-se também, mas em menor número, violência praticada contra a esposa, ex-esposa, mãe e filha.

Consta a violência praticada entre irmãs, ex-sogra, cunhada e ex-namorada. Este último caso envolve conflitos entre a ex-namorada e a atual namorada de um homem. 
DIAS, 2007; SCHRAIBER et al., 2005) Não foram encontrados, nesse grupo, casos de violência doméstica em uniões homoafetivas.

O resultado final das decisões do STJ mostrou que o Tribunal declarou aplicável a Lei Maria da Penha na maioria dos casos de violência doméstica contra a mulher; portanto, no embate entre Varas Criminais e JECrims, foi definida a competência das Varas Criminais para esses casos (79), consoante que determina a Lei Maria da Penha. Em 16 casos, o Tribunal declarou não ser aplicável a Lei Maria da Penha, e sim a Lei n. 9.099, de 1995, dos JECrims. Essas decisões tratam de relações entre namorados (2), ex-namorados (6), irmãs (1), ex-companheiros (2), e outros. (BRASIL, 1995) ${ }^{21}$ A partir desses casos, ressalta-se a dificuldade dos julgadores em incluir no âmbito da LMP os relacionamentos entre namorados, especialmente quando findos.

\section{Análise qualitativa dos argumentos no Juízo de origem e no STJ}

No âmbito dos Juízos de origem predominaram argumentos tendentes a afirmar a competência dos JECrims, como, por exemplo, de que o delito praticado referia-se à infração de menor potencial ofensivo (25); que o artigo 41 da Lei Maria da Penha não previu o afastamento da Lei n. 9.099 (24); a relação íntima de afeto não estava abrangida pela LMP (14); inconstitucionalidade da LMP (10); entre outros de menor ocorrência. (BRASIL, 1995, 2006)

Em consulta individualizada aos processos, verificou-se que esses argumentos provinham, principalmente, das Varas Criminais, vigorando, nesse órgão judiciário, a interpretação de que os casos narrados pelas mulheres ofendidas não passam de simples desavenças, querelas domésticas, as quais não cumprem ao Poder Judiciário interferir. No máximo, seriam da alçada dos

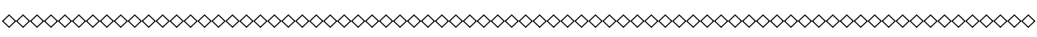

21 Na classificação "outros", apareceram casos (um de cada) em que a pessoa ofendida é a cunhada, o sogro e sogra, ex-sogra, ex-nora e ex-namorado. 
JECrims, que já tratam essas condutas como infração de menor potencial ofensivo e, por essa razão, sujeitas à conciliação ou transação penal.

Segundo Campos (2008), classificar uma ameaça, lesão corporal ou um empurrão, quando cometidos contra as mulheres no espaço doméstico-familiar, como delitos de menor potencial ofensivo, impede aos operadores do Direito estender o olhar para o contexto mais amplo da violência e às relações de gênero intrínsecas a esses delitos, bem como tomar medidas mais severas, como as medidas protetivas de afastamento, proibição de contato, afastamento do lar, entre outras, para a proteção das mulheres em situação de violência que recorrem ao judiciário.

Em razão do intenso debate acerca da (in)constitucionalidade da LMP, ${ }^{22}$ logo ao ser publicada, cabe destacar que o argumento da "inconstitucionalidade da LMP" não se fez presente de forma marcante. Prevaleceram questionamentos pontuais de aplicação da Lei Maria da Penha a respeito da natureza do delito ou das relações afetivas entre as pessoas envolvidas no conflito.

Predominou nas Varas Criminais uma certa "seletividade" nas argumentações quando da análise do caso concreto, em função da pessoa ofendida e do tipo de delito praticado. Nos casos em que a parte ofendida era a esposa ou companheira, em que a relação afetiva é incontroversa, prevaleceu o argumento em relação ao "tipo de delito" praticado, enfatizando sua menor lesividade; nos casos de relacionamentos passados, em que a violência envolve ex-companheira ou ex-namorada, a preferência recaiu no questionamento do "tipo de relação afetiva" existente entre as partes. Em ambos os casos, as argumentações buscaram justificar a remessa dos mesmos aos JECrims. Pode ser percebido um total

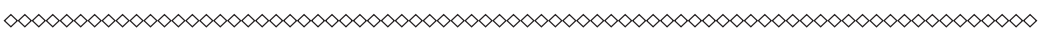

22 Sobre esse debate, ver Silva (2010) e Piovesan e Pimentel (2007). Recentemente, o Supremo Tribunal Federal declarou constitucional a LMP pela Ação Direta de Constitucionalidade n. 19/2012 e Ação Direta de Inconstitucionalidade n. 4424/2012, pondo fim às divergências interpretativas sobre seus dispositivos. (BRASIL, 2012a, b)
} 
descompromisso das Varas Criminais aos recursos interpretativos ditados pela Lei Maria da Penha quanto à observância das condições peculiares das mulheres em situação de violência doméstica. (BRASIL, 2006, Art. $4^{\circ}$ )

Coube aos JECrims, ao receber os casos de violência doméstica e familiar provenientes das Varas Criminais, reafirmarem a competência desses Órgãos, lançando mão de critérios objetivos, em especial que a LMP afastou expressamente a Lei n. 9.099 e, portanto, os JECrims da apreciação desses casos e também de critérios subjetivos, relativos à compreensão de que a LMP, mais severa que a Lei anterior, veio para proteger a família. (BRASIL, 1995)

O estudo realizado por Oliveira (2006), mediante etnografia nos JECrims de Campinas/SP, evidenciou que os operadores do Direito compreendiam a violência como algo restrito à família, devendo ser por ela resolvida, na esfera privada. A partir dessa compreensão, algumas estratégias eram articuladas em Juízo, como a insistência para que as mulheres desistissem da representação e, via de consequência, a desistência do processo contra o ofensor. Os argumentos dos JECrims, detectados nesta pesquisa, de certa forma, confirmam o apontado na pesquisa de Oliveira (2006), pois remanesce a compreensão de que a violência doméstica contra a mulher é problema do âmbito familiar, mas que a LMP, adotando procedimentos especiais e mais severos, intervém em prol da família.

Movidos ou não por interesse em afastar de sua competência esses casos, o fato é que os JECrims, recusando-se a julgar casos antes considerados como delitos de menor potencial ofensivo, quando praticados contra mulheres no ambiente doméstico-familiar, vêm contribuindo para a mudança nas práticas judiciárias, que resistem a um dos principais argumentos feministas acerca dos delitos praticados contra a mulher em contexto de violência doméstica: o de que não são delitos de menor potencial ofensivo, 
e sim uma forma de violação dos direitos humanos das mulheres. Diante disso e considerando a polarização dessa discussão no âmbito de Minas Gerais e apenas em algumas Comarcas, é de se perguntar se a rejeição à LMP pelas Varas Criminais tem ocorrido em outros estados e como tem sido a reação dos JECrims diante desses casos.

O Superior Tribunal de Justiça, perante esse universo de argumentações e tendo que se posicionar para resolver a lide, ora pendia para a aplicação integral da Lei Maria da Penha, ora pela aplicação da Lei n. 9.099, prevalecendo, nesse grupo de decisões, a declaração da competência para as Varas Criminais, afirmando a nova leitura e tratamento conferido pela Lei n. 11.340. (BRASIL, 1995, 2006) Todavia, a análise detida desses julgados, a qual não cabe neste momento detalhar, mostrou que, também no âmbito do STJ, a divergência entre os julgadores era acirrada, revelando interpretações restritivas na maioria das decisões.

Cabe destacar que o STJ pacificou o entendimento de que aos delitos (crime ou contravenção) praticados contra as mulheres no ambiente doméstico-familiar ou nas relações afetivas não se aplica a Lei n. 9.099, de 1995. Assim, contribuiu de forma importante para incluir no âmbito de aplicação da Lei Maria da Penha e, portanto, dos Juizados de Violência Doméstica e Familiar contra a Mulher ou das Varas Criminais todas as condutas lesivas às mulheres praticadas no ambiente doméstico-familiar, seja um empurrão, lesão, ameaça, seja tentativa de homicídio, cárcere privado, estupro, homicídio, entre outras. A confirmação da competência e a adoção de medidas protetivas, na forma delineada pela LMP, são os primeiro passos para a compreensão do caráter complexo e multifacetado da violência doméstica e familiar que atinge as mulheres.

Nos casos em que o debate referia-se ao tipo de relação afetiva a ser abrangida pela LMP, as dificuldades eram maiores, notadamente, em se tratando de relações entre ex-companheiros e ex- 
-namorados. A resistência por parte de ministros(as) em aceitar a definição legal dada pela LMP de que essa Lei é aplicável a "qualquer relação íntima de afeto" pode ser percebida pela criação de correntes interpretativas opostas. Para alguns, estariam amparadas pela LMP as mulheres em relações conjugais, mas não só nessa condição. Haveria também que ser mulheres em relações conjugais e patriarcais, submetidas à opressão e submissão, em relacionamentos duradouros, jamais nas relações afetivas fortuitas ou passageiras. A característica de vítima era buscada nos autos para a afirmação da LMP ao caso concreto e aos procedimentos especiais inscritos nessa Lei. Era visível o caráter nitidamente restritivo dessa interpretação, a qual afastou mulheres que revidaram a agressão, inseridas em relacionamentos passageiros, mulheres pertencentes às relações familiares como irmã, cunhada, nora, sogra, entre outras.

Em oposição a essa corrente, verificou-se outra linha interpretativa, de sentido mais abrangente, pela qual se entendia que a Lei Maria da Penha é aplicável a qualquer relação íntima de afeto, na qual tenha havido ou não convivência com a ofendida, independentemente de coabitação. Entretanto, verificou-se que essa linha interpretativa foi se alterando, fazendo concessões, como forma de "bloquear", pelo menos parcialmente, os argumentos da corrente mais conservadora.

\section{Considerações finais}

Este artigo apresenta os resultados parciais da pesquisa de mestrado referentes às decisões do Superior Tribunal de Justiça, pelas quais se discutia qual era o órgão competente para os casos de violência doméstica contra a mulher.

A partir desses resultados, observou-se que a maioria dos casos de violência doméstica contra a mulher, como ameaça, vias 
de fato, lesão corporal, antes restritos ao âmbito dos JECrims, foi bater às portas de um Tribunal Superior. A “subida” desses casos ao STJ deveu-se à resistência das Varas Criminais em abandonar velhas práticas respaldadas pela Lei n. 9.099, que banalizaram essa violência e trouxeram imenso prejuízo às mulheres em situação de violência, agravando ainda mais um quadro alarmante de violência, estampada nas estatísticas e estudos sobre o tema. (BRASIL, 1995) A LMP exige mais dos operadores do Direito, inclusive a mudança de mentalidade e concepção dessa violência como violação dos direitos humanos das mulheres.

Notou-se a busca pelos recursos da LMP por mulheres ofendidas fora do âmbito apenas conjugal, como ex-companheira, ex-namorada, irmãs, sogra, cunhada, o que sinaliza positivamente para a LMP como um estímulo às denúncias.

Em relação ao tipo de relação afetiva, pode ser percebida uma linha restritiva de interpretação tanto nos Juízos de origem quanto no STJ. Ficou clara a compreensão de que a LMP não seria aplicada a qualquer relação afetiva, em afronta direta ao texto da Lei.

Com referência ainda aos argumentos questionando o tipo de delito, consta-se que as Varas Criminais rejeitaram o caso de violência doméstica contra a mulher ante a compreensão de que se tratava de delito de menor potencial ofensivo e, portanto, sujeito aos ditames dos JECrims. Embora tenham prevalecido decisões no STJ, confirmando a competência das Varas Criminais para julgar os casos de violência doméstica contra a mulher em consonância com a LMP, não se pode ainda mensurar com muita clareza o real alcance da lei ou o quanto essa medida contribui para uma mudança de compreensão da violência doméstica contra a mulher e de mentalidades almejada pela Lei. 


\section{Referências}

AMAZONAS. Resolução $n^{\circ} 16$, de 2007. Dispõe sobre a instalação da Vara da Violência Doméstica e Familiar contra a mulher, e disciplina a competência, na Capital e no Interior do Estado, para ações previstas na Lei 11.340/06. Manaus: Tribunal de Justiça, 2007. Disponível em: <http://www.tjam.jus.br/index.php?option=com_docman\&task=doc view\&gid=32\&Itemid=169>. Acesso em: 2009 .

AZEVEDO, M. A. Mulheres espancadas: a violência denunciada. São Paulo: Cortez, 1985.

BARSTED, L. L. A Lei n. 9.099/95 em debate. Carta da Cepia, Rio de Janeiro, v. 7, n. 9, p. 12, dez., 2001. Disponível em: <http://www.cepia. org.br/doc/cartadacepia9.pdf>. Acesso em: 20 set. 2010.

BARSTED, L. L. Lei contra violência doméstica em coerência com a Conferência de Belém do Pará. Carta da Cepia, Rio de Janeiro, n. 9, n. 11, p. 15, dez., 2003. Disponível em: <http://www.cepia.org.br/doc/ cartadacepia11.pdf > . Acesso em: 20 set. 2009.

BARSTED, L. L.; LAVIGNE, R. R. Proposta de Lei de Violência Doméstica contra as mulheres. Carta da Cepia, Rio de Janeiro, v. 8, n. 10, p. 8-9, dez., 2002. Disponível em: <http://www.cepia.org.br/doc/ cartadacepia10.pdf $>$. Acesso em 20 set. 2009.

BRASIL. Ação Direta de Constitucionalidade n. 19. Brasília: Supremo Tribunal Federal, 2012b. Disponível em <http: / / redir.stf.jus.

br? paginadorpub/paginador.jsp? docTP $=\mathrm{TP} \& \operatorname{docID}=5719497>$. Acesso em: 6 maio 2012.

BRASIL. Ação Direta de Inconstitucionalidade n. 424. Brasília: Supremo Tribunal Federal, 2012a. Disponível em: <http://redir.stf.jus.br/ paginadorpub / paginador.jsp? docTP $=\mathrm{TP} \& \operatorname{docID}=6393143>$. Acesso em: 6 maio 2012.

BRASIL. Conflito de Competência n. 92.591-MG. Brasília: Superior Tribunal de Justiça, 2009. Disponível em: <https://ww2.stj.jus.br/ processo $/$ revista $/$ documento $/$ mediado $/$ ? componente $=$ ITA\&sequencial $=$ $787813 \&$ num_registro $=200702989146 \&$ data $=20090316 \&$ formato $=P D F>$. Acesso em: 25 de jul. 2010.

BRASIL. Decreto-lei n. 3.689 de 3 de outubro de 1941. Brasília, [1941]. Disponível em: <http://www.planalto.gov.br/ccivil_03/Decreto-Lei/ Del3689.htm>. Acesso em 25 set. 2010. 
BRASIL. Lei n. 9.099 de 26 de setembro de 1995. Dispõe sobre os Juizados Especiais Cíveis e Criminais e dá outras providências. Brasília, 1995. Disponível em: <http://www.planalto.gov.br/ccivil_03/leis/ L9099.htm>. Acesso em: 25 set. 2010.

BRASIL. Lei n. 11.340 de 7 de agosto de 2006. Cria mecanismos para coibir a violência doméstica e familiar contra a mulher, nos termos do § $8^{\circ}$ do art. 226 da Constituição Federal, da Convenção sobre a Eliminação de Todas as Formas de Discriminação contra as Mulheres. Brasília, 2006. Disponível em: <http://www.planalto.gov.br/ccivil_03/_ato20042006/2006/lei/l11340.htm>. Acesso em: 25 set. 2010.

BRASIL. Súmula n. 348, 2008. Compete ao Superior Tribunal de Justiça decidir os conflitos de competência entre juizado especial federal e juízo federal, ainda que da mesma seção judiciária. Brasília: STJ, 2008. Disponível em: <http://www.realjus.com.br/dji/normas_inferiores/ regimento_interno_e_sumula_stj/stj__0348.htm > Acesso em: 20 nov. 2010.

BRASIL. Seção de Informação Processual. Brasília, DF: Supremo Tribunal Federal, 2010. Disponível em: <http://www.stj.jus.br/webstj/ processo/Justica/Default.asp $>$. Acesso em: 25 de set. 2010.

CAMPOS, C. H. A Lei 9.099/95: reprivatização do conflito doméstico. Revista Ajuris, Porto Alegre, v. 27, n. 83, set., 2001.

CAMPOS, C. H. Lei Maria da Penha: mínima intervenção punitiva, máxima intervenção social. Revista Brasileira de Ciências Criminais, São Paulo, v. 16, n. 73, jul./ago, p. 244-267, 2008.

GREGORI, M. F. Cenas e queixas: um estudo sobre as mulheres: relações violentas e prática feminista. São Paulo: Paz e Terra, 1993.

MACHADO, C.; DIAS, A. R. Cultura e violência familiar: uma revisão crítica da literatura. Revista Brasileira de Informação bibliográfica em Ciências Sociais, BIB, São Paulo, n. 64, $2^{\circ}$ semestre, p. 43-74, 2007.

NUCCI, G. S. Prática forense penal. 4.ed. rev., atual. e ampl. São Paulo: Revista dos Tribunais, 2009.

OBSERVATÓRIO PELA APLICAÇÃO DA LEI MARIA DA PENHA (OBSERVE). Projeto: construção e implementação do Observatório da Lei 11.340/2006 - Lei Maria da Penha: monitoramento da Lei Maria da Penha, Relatório preliminares de pesquisa. Salvador, 2009. Disponível em: <http://www.spm.gov.br/lei-maria-da-penha/lei-maria-dapenha/20090806-relatorio-final-2009.pdf>. Acesso em: 5 jul 2010. 
OBSERVATÓRIO PELA APLICAÇÃO DA LEI MARIA DA PENHA

(OBSERVE). Condições para aplicação da Lei 11.340/2006 (Lei Maria

da Penha) nas Delegacias Especializadas de Atendimento à Mulher

(DEAMS) e nos Juizados de Violência Doméstica e Familiar nas

capitais e no Distrito Federal: Relatório Final. Salvador, 2010.

OLIVEIRA, M. B. Crime invisível: mudança de significados da violência de gênero no Juizado Especial Criminal. 215 f. Dissertação (Mestrado em antropologia social) - Universidade Estadual de Campinas - Instituto de Filosofia e Ciências Humanas, Campinas, 2006.

PANDJIARJIAN, V. Os estereótipos de gênero nos processos judiciais e a violência contra a mulher na legislação. Rio de Janeiro: IPAS-Brasil, 2002. Disponível em: <http://www.tjmt.jus.br/INTRANET.ARQ/CMS/ GrupoPaginas/59/459/file/estereotipos_Genero_Valeria_Pandjiarjian. doc $>$. Acesso em: 20 set. 2010.

PIOVESAN, F.; PIMENTEL, S. Lei Maria da Penha: inconstitucional não é a lei, mas a ausência dela. Revista Eletrônica Carta Maior, [São Paulo],12 out., 2007. Disponível em: <http://www.cartamaior.com.br/ templates/analiseMostrar.cfm? coluna_id=3743>. Acesso em: dez. 2009.

SCHRAIBER, L. B. et al. Violência dói e não é direito: a violência contra a mulher, a saúde e os direitos humanos. São Paulo: UNESP, 2005.

SCOTT, J. Gênero: uma categoria útil de análise histórica. Educação \& Realidade, Porto Alegre, v. 20, n. 2, p. 71-99, jul./dez., 1995.

SILVA, L. S. O queres tu mulher? manifestações de gênero no debate de constitucionalidade da Lei Maria da Penha. 2009. Dissertação (Mestrado em Ciências sociais) - Pontifícia Universidade Católica de São Paulo, 2009. Disponível em: <http://livros01.livrosgratis.com.br/cp122057. pdf $>$. Acesso em: 5 jul. 2010. 


\title{
CONSTITUCIONALIDADE DA LEI MARIA DA PENHA ${ }^{1}$
}

\author{
Rúbia Abs da Cruz
}

O artigo buscará relatar as ações políticas e jurídicas que envolvem a análise de dispositivos da Lei Maria da Penha Ação Direta de Constitucionalidade (ADC 19) e Ação Direta de Inconstitucionalidade (ADI 4424) - no Supremo Tribunal Federal (STF). Em relação à parte jurídica, o voto do relator foi pela procedência da ADC 19, a fim de declarar a constitucionalidade dos $\operatorname{artigos} 1^{\circ}, 33^{\circ}$ e $41^{\circ}$ da Lei 11.340/2006, conhecida como Lei Maria da Penha. Essa norma, elaborada inicialmente pelo movimento feminista para proteção às mulheres, criou mecanismos para coibir a violência doméstica e familiar contra a mulher, entretanto, proporciona tratamento desigual (ou diferenciado) aos iguais perante a Constituição Federal. (BRASIL, 2006) Os ministros e ministras endossaram o princípio do tratamento desigual às mulheres, em face de sua histórica desigualdade perante os homens dentro do lar.

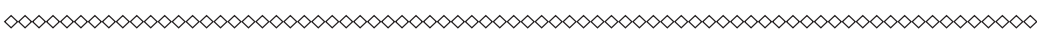

1 Este artigo já foi publicado sem as atualizações e correções desta publicação. 0 artigo foi publicado no Relatório Azul. Lei Maria da Penha e a Violência Contra a Mulher. Comissão de Cidadania da Assembleia Legislativa do Estado do Rio Grande do Sul, p. 389 a 396. Porto Alegre, Assembleia Legislativa, 2012. 


\section{É importante citar os artigos analisados na ADC 19 pelo STF:}

Art. $1^{\circ}$ - Esta Lei cria mecanismos para coibir e prevenir a violência doméstica e familiar contra a mulher, nos termos do $\S 8^{\circ}$ do art. 226 da Constituição Federal, da Convenção sobre a Eliminação de Todas as Formas de Violência contra a Mulher, da Convenção Interamericana para Prevenir, Punir e Erradicar a Violência contra a Mulher e de outros tratados internacionais ratificados pela República Federativa do Brasil; dispõe sobre a criação dos Juizados de Violência Doméstica e Familiar contra a Mulher; e estabelece medidas de assistência e proteção às mulheres em situação de violência doméstica e familiar.

Art. $33^{\circ}$. - Enquanto não estruturados os Juizados de Violência Doméstica e Familiar contra a Mulher, as varas criminais acumularão as competências cível e criminal para conhecer e julgar as causas decorrentes da prática de violência doméstica e familiar contra a mulher, observadas as previsões do Título IV desta Lei, subsidiada pela legislação processual pertinente.Parágrafo único - Será garantido o direito de preferência, nas varas criminais, para o processo e o julgamento das causas referidas no caput.

Art. $41^{\circ}$. - Aos crimes praticados com violência doméstica e familiar contra a mulher, independentemente da pena prevista, não se aplica a Lei 9.099, de 26 de setembro de 1995. (BRASIL, 2006)

Segue abaixo a informação processual da ADC 19, que demonstra o trabalho das organizações aceitas no Amicus Curiae, ${ }^{2}$ que figura juridicamente como Intervenção de Terceiros por terem interesse no litígio. (STF..., 2008)

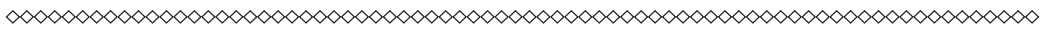

2 Amicus curiae é um recurso processual aberto a interessados na matéria debatida e significa Amigos da Curia ou da Corte. 0 Amicus Curiae repassa informações e dados sobre o problema no processo que está sendo julgado no Supremo Tribunal Federal. 


\section{Dados Gerais}

Processo: ADC 19 DF

Relator(a): Min. MARCO AURÉLIO

Julgamento:13/12/2008

Publicação: DJe-022 DIVULG 02/02/2009 PUBLIC 03/02/2009

Parte(s):

PRESIDENTE DA REPÚBLICA

ADVOGADO-GERAL DA UNIÃO

CONSELHO FEDERAL DA ORD

EM DOS ADVOGADOS DO BRASIL

MAURÍCIO GENTIL MONTEIRO E OUTROS

THEMIS - ASSESSORIA JURÍDICA E ESTUDOS DE GÊNERO IPE - INSTITUTO PARA A PROMOÇÃO DA EQUIDADE INSTITUTO ANTÍGONA

RÚBIA ABS DA CRUZ

\section{Decisão}

Petição/STF n ${ }^{\circ}$ 166.238/2008 PROCESSO OBJETIVO ‘ADMISSÃO DE TERCEIRO. 1. Eis as informações prestadas pela Assessoria: A Assessoria Jurídica e Estudos de Gênero - THEMIS, o Instituto para a Promoção da Eqüidade ' IPÊ e o Instituto Antígona, organizações integrantes e representantes do Comitê Latino Americano e do Caribe para a Defesa dos Direitos da Mulher 'CLADEM/Brasil, em petição subscrita por profissional da advocacia, requerem sejam admitidos no processo em referência, na qualidade de amicuscuriae. Tecem considerações sobre o mérito e apresentam instrumento de mandato desacompanhado dos atos constitutivos. Registro que o processo está na Procuradoria Geral da República. 2. A regra é não se admitir intervenção de terceiros no processo de ação direta de inconstitucionalidade, iniludivelmente objetivo. A exceção corre à conta de parâmetros reveladores da relevância da matéria e da representatividade do terceiro, quando, então, por decisão irrecorrível, é possível a 
manifestação de órgãos ou entidades ' artigo $7^{\circ}$ da Lei n. 9.868, de 10 de novembro de 1999. No caso, está em questão a Lei n. 11.340/2006, denominada Lei Maria da Penha. Os Institutos têm como objetivo a proteção da mulher. 3 . Admito-os como terceiros. 4. Publiquem. Brasília, 13 de dezembro de 2008. Ministro MARÇO AURÉLIO Relator. (STF..., 2008)

A decisão do Supremo Tribunal Federal publicada no site do Supremo tratou da Constitucionalidade em relação aos artigos citados, mas destacarei os argumentos relacionados com o artigo $1^{\circ}$, que trata da igualdade entre homens e mulheres, e farei um breve comentário sobre os artigos 33 e 41, que seguem. (BRASIL, 2012)

Assim, faço breves considerações de acordo com a decisão. $\mathrm{O}$ relator, ministro Marco Aurélio, que considerou constitucional o preceito do artigo 33, da Lei n. 11.340/2006, segundo o qual, enquanto não estruturados os Juizados de Violência Doméstica e Familiar contra a Mulher, as varas criminais acumularão as competências cível e criminal para conhecer e julgar as causas decorrentes da prática de violência doméstica e familiar contra a mulher, "observadas as previsões do Título IV desta Lei, subsidiada pela legislação processual pertinente”. Ele ressaltou não haver ofensa ao artigo 96, inciso I, alínea "a" e 125, parágrafo $1^{\circ}$, da Constituição Federal (CF), mediante os quais se confere aos estados a competência para disciplinar a organização judiciária local. (BRASIL, 1988, 2006)

Além disso, entendeu que a constitucionalidade do artigo 41 dá concretude, entre outros, ao artigo 226, parágrafo $8^{\circ}$, da (CF), que dispõe que "o Estado assegurará a assistência à família na pessoa de cada um dos que a integram, criando mecanismos para coibir a violência no âmbito de suas relações.” (BRASIL, 1988)

O ministro Ricardo Lewandowski afirmou que o legislador, ao votar o artigo 41 da Lei Maria da Penha, disse claramente que o 
crime de violência doméstica contra a mulher é de maior poder ofensivo, ou seja, fora do âmbito da Lei n. 9.099/95, que previa como de competência do Juizado Especial Criminal, que trata de crimes de menor potencial ofensivo. (BRASIL, 1995; 2012) A violência diária é crime de grande potencial ofensivo. Embora nem sempre tenha que ser penalizada com cárcere, a violência doméstica contra a mulher deverá sim ser penalizada com medidas alternativas e reconhecida como um problema social, que desencadeia várias formas de violências consideradas mais graves no âmbito penal. Somente com o reconhecimento da potencialidade da violência cotidiana será possível trabalharmos na prevenção e na reeducação de padrões socioculturais, apostando na socialização e respeito das diferenças e das relações. A violência cotidiana gera várias consequências, inclusive sociais, já que a violência aprendida dentro de casa tende a se reproduzir nas ruas!

O Mapa da Violência - em pesquisa conduzida pela Secretaria de Políticas para as Mulheres (SPM) - mostra ser muito alto o índice de assassinatos de mulheres no Brasil. (WAISELFIS, 2011; CNJ, 2012c)

De acordo com a pesquisa, de 1980 a 2010, aproximadamente 91 mil mulheres foram assassinadas, sendo 43,5 apenas na última década. O Espírito Santo lidera o ranking nacional, com taxa de 9,4 homicídios para cada 100 mil mulheres. Na sequência estão Alagoas $(8,3)$, Paraná $(6,3)$, Paraíba $(6,0)$ e Mato Grosso do Sul $(6,0)$. Ainda segundo o Mapa da Violência, $68,8 \%$ dos incidentes acontecem na residência, levando-nos à conclusão de que é no âmbito doméstico onde ocorre a maior parte das situações de violência experimentadas pelas mulheres.

O Mapa da Violência foi recentemente publicado, em que poucos dados foram agregados. (WAISELFIS, 2011, 2012)

Seguirei com o Artigo $1^{\circ}$ da Lei Maria da Penha, que dispõe sobre o tratamento diferenciado em relação às mulheres e que foi 
questionado basicamente devido à igualdade constitucional entre homens e mulheres. O ministro do Supremo Tribunal Federal, Marco Aurélio, afirmou que o dispositivo se coaduna com o que propunha Ruy Barbosa, segundo o qual a regra de igualdade é tratar desigualmente os desiguais. Isso porque a mulher, ao sofrer violência no lar, encontra-se em situação desigual perante o homem. A essa afirmação do ministro, acrescento uma das hipóteses da pesquisa realizada enquanto coordenadora da THEMIS, publicada no livro Nominando o inominável, (CRUZ; SILVEIRA, 2008) em que uma das hipóteses é a de que a mulher encontra um equilíbrio na relação, mesmo que temporário, quando busca ajuda externa na polícia e no Judiciário. Isso demonstra a desigualdade na relação, embora a Constituição promova a igualdade de todos, ou de "todas", perante a Lei.

O que também se coaduna com a afirmação célebre de Boaventura de Souza Santos ([20-- ]): “Temos o direito a sermos iguais quando a diferença nos inferioriza. Temos o direito a sermos diferentes quando a igualdade nos descaracteriza." Também destacou o ministro que a violência contra a mulher é grave, pois não se limita apenas ao aspecto físico, mas também ao seu estado psíquico e emocional. Importante observação, pois a violência diária ocorre especialmente com a retaliação da autoestima da mulher, gerando várias consequências negativas.

Por seu turno, o ministro Joaquim Barbosa concordou com o argumento de que a Lei Maria da Penha buscou proteger e fomentar o desenvolvimento do núcleo familiar sem violência, sem submissão da mulher, contribuindo para restituir sua liberdade, assim acabando com o poder patriarcal do homem em casa.

Na análise dos votos dos ministros quanto à igualdade entre homens e mulheres foi possível sentir que valeu a pena! Valeu ter ajudado na construção da Lei, ter participado de audiências públicas, batalhas para aprovar a Lei, apresentar Amicus Curiae ao Supremo 
pela Constitucionalidade da Lei Maria da Penha na ADC 19, capacitar pessoas sobre a Lei, realizar o I Encontro Nacional de Promotoras Legais Populares para Implementação da Lei, fazer trabalho de advocacy com os ministros junto com a Articulação de Mulheres Brasileiras (AMB) e as ONGs do Consórcio e do Observatório Lei Maria da Penha (Observe), enfim, foi possível perceber as nossas concepções na decisão. Mudamos concepções e crenças, modificamos a cultura jurídica, talvez não a cultura machista, mas parte dela. Fizemos um bom trabalho, e foi bom desde o início, quando o Comitê Latino Americano e do Caribe para a Defesa dos Direitos da Mulher (Cladem) e Center for Justice and Law Cejil ajuizaram o caso Maria da Penha Fernandes perante a Comissão Interamericana de Direitos Humanos (CIDH) e, ainda antes, quando adquirimos o direito à educação, ao voto, às delegacias de mulheres e aos conselhos de diretos, entre outras tantas possibilidades que se abriram às mulheres nos mais variados campos.

Comemoramos quando o caso foi admitido pela CIDH e alcançamos o mérito da decisão com as Recomendações ao Brasil! O movimento feminista, acompanhando o caso, iniciou um trabalho de elaboração dessa possível e futura Lei Federal. Pretensiosas e esperançosas, bravas mulheres, como Silvia Pimentel, Leila Linhares, Valéria Pandjiarjian, Rosane Lavigne, Miriam Ventura, Ella Wiecko, Myllena Calasans, Carmen Campos, Iáris Ramalho, entre outras, colaboraram na elaboração dessa Lei. Outras integrantes da THEMIS, Advocacy, Cladem e Cidadania, Estudo, Pesquisa, Informação e Ação (Cepia) também colaboraram, e outras tantas foram fundamentais, como a ministra Nilcéa Freire, que recebeu nosso documento em formato de projeto de lei e fez os devidos encaminhamentos. Destaco também Jandira Feghali, à época deputada federal, que promoveu as audiências públicas nas capitais do Brasil sobre o tema, trabalhando no projeto de lei encaminhado pela Secretaria de Políticas para as Mulheres. 
Mas, intimamente, o que mais me motivou a lutar pela Lei foram as mulheres atendidas na advocacia feminista da THEMIS, nas palestras e oficinas realizadas, nas audiências de juizados especiais criminais ou em varas de família - posso dizer que, em especial, pelo aprendizado com as Promotoras Legais Populares (PLPs). As PLPs inicialmente despertaram em mim um misto de dúvida e confiança, mas, com o tempo, se tornaram a minha grande esperança de um mundo melhor; assim como aprendi com os movimentos feministas e de mulheres negras, com as cidadãs positivas, com as Jovens Multiplicadoras de Cidadania (JMC's) e com as mulheres da paz! Tantas mulheres que me relataram as mais diversas formas de violências sofridas. Vidas perdidas ao longo da caminhada! Vidas sem amor e em busca do amor! Vidas com muita dor!

Enfim, como dizia, valeu a pena!

Foi um dia de vitória para as mulheres brasileiras e comemoramos com a Secretaria de Políticas para as Mulheres, com a então ministra Iriny Lopes, Aparecida Gonçalves, Regina Adami, Ana Paula Gonçalves, Ane Cruz e outras que estiveram envolvidas desde que o Consórcio de Organizações Não Governamentais (ONGs) apresentou a modelo de projeto de lei até a sua aprovação enquanto Lei Maria da Penha. Outra batalha vencida! Agora seguimos buscando juntas uma nova cultura jurídica e social para a definitiva implementação da Lei.

A desigualdade histórica da mulher em relação ao homem se reflete em desigualdades na própria justiça. Exemplo disso é que até meados de 1970, talvez um pouco mais, os homens ainda eram absolvidos sob o argumento da "legítima defesa da honra", conforme construção jurisprudencial, quando o homem alegava ter matado por adultério/traição, mesmo que não em flagrante. Construção jurisprudencial absolutamente machista e desigual, sem a menor equivalência ao menos jurídico-penal, entre honra 
e direto à vida. Felizmente, o direito brasileiro vem evoluindo e encontrou seu ápice na Constituição de 1988, que assegurou, em seu texto, a igualdade entre homem e mulher. Igualdade entre homens e mulheres é uma realidade jurídica que precisamos alcançar em todos os países que fazem parte do sistema interamericano, em especial latino-americanos e caribenhos.

Participando do Cladem regional, foi possível observar a impunidade em índices mais perversos que os nossos nos países da região. Na Guatemala, casos de femicídio, ${ }^{3}$ em sua maioria, sequer contam com inquéritos policiais. Não são formalizados ou encaminhados ao Judiciário. A impunidade é absurda, e a morte de uma mulher nessas circunstâncias é banalizada e naturalizada. No Brasil, em casos de femicídio (mesmo que não tenha essa nomenclatura tipificada, chamando-se de homicídio), é realizado um inquérito policial, ocorrendo a investigação criminal e posterior denúncia do Ministério Público ao juiz, ou seja, na maioria das vezes o procedimento chega ao Tribunal do Júri, mesmo que o réu seja absolvido ou o crime acabe prescrito. Ao menos se exige um rito processual e julgamento. Na Guatemala, não há sequer o indiciamento na maioria dos casos. Situações semelhantes se encontram em Honduras, El Salvador e até no México.

Algumas mulheres que vivem em regiões como as citadas não creem no valor de suas próprias vidas. São submissas por sobrevivência. Nesse sentido, votou a ministra Carmen Lúcia, lembrando que o "direito não combate preconceito, mas sua manifestação". "Mesmo contra nós há preconceito", observou ela, referindo-se, além dela, à ministra Ellen Gracie e à vice-procuradora-geral da República, Deborah Duprat. Importante referir essa citação da ministra, pois em graus diferenciados, as violações de direitos

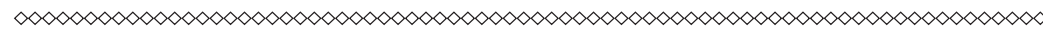
3 Quando os homens assassinam mulheres devido à violência de gênero e cultura patriarcal. 
em relação às mulheres acabam se manifestando. (BRASIL, 2006; BRASIL, [2011])

Destaca-se, nesse sentido, que a decisão da Comissão Interamericana de Direitos Humanos (OEA, 2001), relacionada à Lei Maria da Penha, colabora com medidas preventivas e punitivas para todos os países do Sistema Interamericano, em maior ou menor medida, é valorada como jurisprudência internacional, em especial para os países que ratificaram as Convenções.

A dignidade humana é valor imperativo e fundamento da nossa Constituição Federal. Para além da Lei Maria da Penha, contamos com a Constituição Federal e com a Convenção Interamericana para Prevenir, Punir e Erradicar a Violência contra a Mulher e com a Convenção Interamericana pela Eliminação de todas as Formas de Discriminação Contra a Mulher (ONU, 1979; OEA,1994), estando o Estado obrigado a agir com zelo na prevenção e punição da violência contra mulher. A CIDH Humanos recomendou ao Brasil medidas nesse sentido justamente por ter negligenciado um caso de violência doméstica com tentativa de homicídio denunciado por Maria da Penha Fernandes (entre tantos outros). O caso permaneceu impune e sem julgamento definitivo por mais de 12 anos no Brasil.

Com base nas Recomendações da CIDH, foram realizadas capacitações em relação à violência doméstica e familiar contra a mulher para policiais civis e militares, mas também junto a vários profissionais da área do direito. Da mesma forma, a CIDH recomendou uma legislação específica. Criamos e aprovamos a Lei Maria da Penha e agora buscamos sua efetiva implementação, seja junto ao Observe, seja em ações pontuais em diversos estados brasileiros.

Apresento dados do Conselho Nacional de Justiça (CNJ) junto aos juizados e varas especializadas nos processos de violência doméstica contra a mulher. Tal levantamento revelou um crescimento de $106,7 \%$ no número de procedimentos instaurados, com 
base na Lei Maria da Penha, no período de julho de 2010 a dezembro de 2011. Desde a sanção da Lei Maria da Penha (Lei 11.340), em 2006, até dezembro de 2011 foram instaurados 685.905 processos nos estados. Outra informação importante é que 408 mil desses procedimentos foram julgados e encerrados. (CNJ, 2012a)

O número de prisões em flagrante e de prisões preventivas decretadas foi ainda maior. A apuração do CNJ mostra que, entre os tipos de procedimentos, as prisões em flagrante aumentaram $171 \%$, alcançando 26.416 em dezembro de 2011. Já as decretações de prisões preventivas chegaram a 4.146, tendo sido ampliadas em $162 \%$. (CNJ, 2012a)

A região Sudeste foi a que registrou maior número de procedimentos (250 mil), seguida da região Sul (110 mil). Quanto aos processos julgados e encerrados, o Sudeste também liderou as ocorrências (130 mil), à frente do Centro-Oeste (90 mil).

Dentre os estados, o destaque em termos de aplicação da lei tem sido o Rio de Janeiro, com 157.430 procedimentos instaurados. Em segundo lugar, vem o Rio Grande do Sul, onde foram abertos 81.197 procedimentos, destacando-se nesse estado o importante trabalho de coleta de dados do Ministério Público Estadual. Também figuram na lista das unidades da Federação com maior aplicação da Lei Maria da Penha: Minas Gerais (com 64.034 procedimentos), Paraná (26.105) e Espírito Santo (21.505).

Não é por acaso que nesses estados contamos com Defensorias Públicas mais estruturadas e organizadas. Precisamos de mais defensores públicos para assegurar o acesso à justiça. Precisamos de mais policiais civis para realização dos inquéritos policiais. Precisamos de políticas públicas específicas que contribuam na prevenção da violência doméstica e familiar contra a mulher. Sim, precisamos de meios para assegurar os direitos adquiridos e, embora na prática ainda soframos violações, também devemos 
reconhecer que conquistamos muitos direitos, inclusive na mais alta Corte do nosso país!

E, trazendo dados sobre o julgamento da ADI 4424, o Supremo Tribunal Federal reconheceu que nos crimes de lesões corporais leves a ação penal é pública incondicionada, quando aplicável a Lei Maria da Penha (violência doméstica) (AMARAL, 2012), o que significa que o Ministério Público poderá dar início à ação penal pública mesmo sem representação da vítima. (ADI sobre a representação da vítima em caso de lesão corporal não poder ser retirada e ser denunciada pelo Ministério Público..., (ADI..., 2012a, b) A ação direta de inconstitucionalidade (ADI 4424) ajuizada pelo procurador-geral da República, Roberto Gurgel, sobre a aplicação de dispositivos da Lei Maria da Penha questionava a aplicação de dispositivos da Lei n. 9.099/95 após a edição da Lei Maria da Penha de 2006.

Não resta dúvida que ações afirmativas são absolutamente necessárias para construirmos um mundo mais igualitário! A Lei Maria da Penha e a decisão do Supremo Tribunal Federal reafirmam essa conclusão. Parabéns a todas as mulheres que, de uma forma ou de outra, contribuíram para essa conquista histórica! Parabéns ao Consórcio de ONGs, ao Observe, ao Núcleo de Estudos Interdisciplinares sobre a Mulher da Universidade Federal da Bahia (NEIM/UFBA) e a Secretaria de Políticas para as Mulheres, que estão possibilitando contarmos essa história!

\section{Referências}

AMARAL, C. E. R. do. ADI 4424: decisão do STF sobre Lei Maria da Penha deve ter eficácia ex nunc. Jornal da Brasil, Rio de Janeiro, 14 abr. 2012. Disponível em: <http://www.jb.com.br/sociedade-aberta/ noticias/2012/04/15/adi-4424-decisao-do-stf-sobre-lei-maria-dapenha-deve-ter-eficacia-ex-nunc/ > . Acesso em: 12 nov. 2012. 
ADC 19: STF declara a constitucionalidade de dispositivos da Lei Maria da Penha. JusBrasil, [2012]. Disponível em: <http://stf.jusbrasil.com. $\mathrm{br} /$ noticias/3016738/adc-19-stf-declara-a-constitucionalidade-dedispositivos-da-lei-maria-da-penha>. Acesso em: 5 nov. 2012.

ADI 4424. JusBrasil, [2012b]. Disponível em: <http://www.jusbrasil. com.br/topicos/26900618/adi-4424>. Acesso em: 2015.

ADI SOBRE Maria da Penha é julgada procedente pelo STF. JusBrasil, [2012a]. <http://mpf.jusbrasil.com.br/noticias/3018354/adi-sobre-leimaria-da-penha-e-julgada-procedente-pelo-stf $>$. Acesso em: 25 abr. 2015.

BRASIL. Ação Direta de Constitucionalidade n. 19. Brasília: Supremo Tribunal Federal, 2012. Disponível em <http://redir.stf.jus. br? paginadorpub/paginador.jsp? docTP $=\mathrm{TP} \&$ docID $=5719497>$. Acesso em: 6 maio 2012.

BRASIL. ADC 19: dispositivos da Lei Maria da Penha são Constitucionais. Brasília: Superior Tribunal De Justiça, [1998]. Disponível em: $<$ http://www.stf.jus.br/portal/cms/verNoticiaDetalhe. asp?idConteudo=199845 $>$. Acesso em: 5 nov. 2012.

BRASIL. Constituição Da República Federativa Do Brasil. Brasília: Senado Federal, 1988. Disponível em: <http://www.planalto.gov.br/ ccivil_03/Constituicao/ConstituicaoCompilado.htm>. Acesso em: 2015.

BRASIL. Lei n. 9.099 de 26 de janeiro de 1995. Dispõe sobre os Juizados Especiais Cíveis e Criminais e dá outras providências. Brasília, DF, 1995. Disponível em: <https://www.planalto.gov.br/ccivil_03/LEIS/L9099. htm $>$. Acesso em: 2015.

BRASIL. Lei 11.340 de 7 de agosto de 2006. Cria mecanismos para coibir a violência doméstica e familiar contra a mulher, nos termos do $\$ 8^{\circ} \mathrm{do}$ art. 226 da Constituição Federal, da Convenção sobre a Eliminação de Todas as Formas de Discriminação contra as Mulheres. Brasília, DF, 2006. Disponível em: <http://www.planalto.gov.br/ccivil_03/_ ato2004-2006/2006/lei/111340.htm>. Acesso em: 25 set. 2010.

BRASIL. STF declara constitucionalidade do artigo 41 da Lei Maria da Penha. Destaques, Brasília, [2011]. Disponível em: <http:// www2.stf.jus.br/portalStfInternacional/cms/destaquesClipping. php? sigla=portalStfDestaque_pt_br\&idConteudo=175335 $>$. Acesso em: 2015. 
CARNEIRO, L. O. STF confirma constitucionalidade da Lei Maria da Penha. Jornal do Brasil, [Rio de Janeiro], 9 fev. 2012. Disponível em: $<$ http://www.jb.com.br/pais/noticias/2012/02/09/stf-confirma-porunanimidade-constitucionalidade-da-lei-maria-da-penha/ > . Acesso em: 30 out. 2012.

CRUZ, R. A. da, SILVEIRA, A. I.; PASINE E. Nominando o Inominável: violência contra a mulher e o poder judiciário. Porto Alegre: Themis, 2008.

CONSELHO NACIONAL DE JUSTIÇA (CNJ). Procedimentos instaurados pela Lei Maria da Penha cresceram mais de $100 \%$. Notícias, Brasília, DF, 25 abr. 2012a. Disponível em: <http://www.cnj.jus.br/noticias/ cnj/58624-procedimentos-instaurados-pela-lei-maria-da-penhacresceram-mais-de-100>. Acesso em: 10 nov. 2012.

CONSELHO NACIONAL DE JUSTIÇA (CNJ). Conselho Nacional de Justiça divulga número sobre aplicação da Lei Maria da Penha. Observatório Brasil da Igualdade de gênero. Brasília, [2012b]. Disponível em: <http:// www.observatoriodegenero.gov.br/menu/noticias/brasil-tem-maisde-150-mil-processos-referentes-a-violencia-contra-mulher $>$. Acesso em: 10 nov. 2012.

CONSELHO NACIONAL DE JUSTIÇA (CNJ). Lei Maria da Penha completa seis anos de vigência. Notícias, Brasília, DF, 7 ago. 2012c. Disponível em: http://www.cnj.jus.br/noticias/cnj/59036-lei-maria-da-penhacompleta-seis-anos-de-vigencia $>$. Acesso em: 5 nov. 2012.

ORGANIZAÇÃO DOS ESTADOS AMERICANOS (OEA). Caso 12.051: Maria Da Penha Maia Fernandes: BRASIL, 4 de abril de 2001. In: Relatório anual 2000: n. 54/01. Washington, 2001. Disponível em: <http://cidh.oas.org/annualrep/2000port/12051.htm〉. Acesso em: 2015.

ORGANIZAÇÃO DOS ESTADOS AMERICANOS (OEA). Convenção de Belém Do Pará. Pará, 1994. Disponível em: <http://www.cidh.org/ Basicos/Portugues/m.Belem.do.Para.htm>. Acesso em: 2015.

ORGANIZAÇÃO NAÇÕES UNIDAS (ONU). Convenção sobre a eliminação de todas as formas de discriminação contra a mulher. [S.l.]: ONU Mulheres, 1979. Disponível em: <http://www.pge.sp.gov. $\mathrm{br} /$ centrodeestudos/bibliotecavirtual/instrumentos/discrimulher. htm $>$. Acesso em: 2015. 
WAISELFIS Z, J. J. Mapa da violência 2012: os novos padrões da violência homicida no Brasil. São Paulo: Instituto Sangari, 2011. Disponível em: 〈http://www.mapadaviolencia.org.br/pdf2012/mapa2012_web.pdf〉. Acesso em: 2015.

WAISELFIS Z, J. J. Mapa da violência 2012: caderno complementar 1: homicídio de mulheres no Brasil. São Paulo: Instituto Sangari, 2012. Disponível em: <http://www.mapadaviolencia.org.br/pdf2012/ mapa2012_mulher.pdf >. Acesso em: 2015.

SANTOS, B. de S. Pensador. [20--]. Disponível em: <http:// pensador. uol.com.br/frase/MTEzNTExNw/>. Acesso em: 2015.

STF - Ação Declaratória De Constitucionalidade: ADC 19 DF. JusBrasil, 2008. Disponível em: <http://stf.jusbrasil.com.br/ jurisprudencia/14767701/acao-declaratoria-de-constitucionalidadeadc-19-df-stf $>$. Acesso em: 10 de novembro de 2012. 


\section{SAÚDE E VIOLÊNCIA DE GÊNERO necessário monitoramento ${ }^{1}$}

Telia Negrão

\section{Antecedentes}

Invisível no Brasil até a década de 1970, presente na agenda da sociedade e nas políticas públicas dos dias atuais, a violência de gênero ${ }^{2}$ mantém-se como um tema instigante e provocador de novas abordagens. Mesmo enfocada desde 1984, por vários documentos internacionais (OEA, 1993, 1994), apenas em 2006 o país passou a contar com legislação específica para tratar da violência doméstica e familiar, que, a despeito de suas limitações, se tornou um marco para a defesa dos direitos humanos no país. Novas leis e reflexões surgem à medida que se aprofunda a compreensão sobre o problema e novas interseções são reconhecidas, entre elas as re-

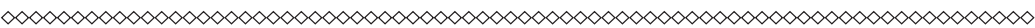

1 Este artigo traz argumentos levantados para projetos da Rede Feminista de Saúde, feitos pela autora em parceria com Maria Luisa Pereira de Oliveira para a Campanha Ponto Final.

2 Aqui se confere à terminologia de violência de gênero e violência contra a mulher a mesma significação, considerando-se as diversas formas de exercício de poder como uso da força e da coerção contra as mulheres. 
lações entre violência e saúde, em especial sexualidade e reprodução, além do aborto, do Vírus da Imunodeficiência Humana (HIV) e da Aids. (BRASIL, 2013)

A Lei Maria da Penha (LMP) resultou de prolongado processo de luta das mulheres e da condenação por omissão do Estado brasileiro pela Corte Interamericana de Justiça. Ao ser sancionada, responsabilizou a União, Governos Estaduais, Distrito Federal, Governos Municipais, Poder Judiciário e também a sociedade civil, alertando que a coibição dessa violência se localiza entre os fenômenos sociais de raízes profundas, um produto histórico da constituição imaginária da sociedade, do seu imaginário social (BRASIL, 2006; STREY, 2004, p. 33), portanto, com potente significado cultural. Por seu caráter complexo, essa lei prevê a interface com a saúde, ${ }^{3}$ abrindo campo para intervir com múltiplos olhares em termos de políticas públicas, entre os quais os direitos sexuais e reprodutivos das mulheres.

Assim, a conquista de uma legislação específica para a violência doméstica e a sua implementação têm sido uma provocação ao movimento de mulheres e aos setores da sociedade que trabalham para reduzir as desigualdades de gênero. (NEGRÃO; PRÁ, 2005) Pois, se de um lado há um esforço para a efetivação da lei com a instalação de delegacias, juizados, centros de referência, casas de abrigo - uma rede de atendimento -, de outro se revelam resistências e iniciativas provenientes do mesmo poder judiciário, de

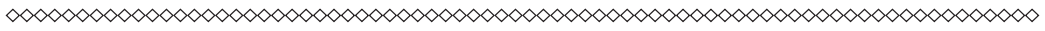

3 Neste sentido, a LMP previu a abordagem em saúde em dois tópicos: no Artigo $9^{\circ}$, caput, quando diz que "a assistência à mulher em situação de violência doméstica e familiar será prestada de forma articulada e conforme os princípios e as diretrizes da Lei Orgânica da Assistência Social, no Sistema Único de Saúde e no Sistema Único de Segurança Pública, entre outras normas e políticas públicas de proteção, e emergencialmente quando for o caso"; e no parágrafo $3^{\circ}$ do mesmo artigo, em que esta assistência "compreenderá o acesso aos benefícios decorrentes do desenvolvimento científico e tecnológico, incluindo os serviços de contracepção de emergência, a profilaxia das Doenças Sexualmente Transmissíveis (DST) e da Síndrome da Imunodeficiência Adquirida (AIDS) e outros procedimentos médicos necessários e cabíveis nos casos de violência sexual". 
setores conservadores dos governos e da sociedade e de membros do congresso nacional que a colocam em risco.

Ao questionar sua aplicabilidade e sua constitucionalidade sob a alegação de promover a discriminação, demonstra-se um desconhecimento do conceito de "discriminação positiva" introduzido pela Convenção sobre a Eliminação de Todas as Formas de Discriminação à Mulher (Cedaw), segundo a qual medidas especiais para acelerar a igualdade entre os sexos deixam de ser negativamente discriminatórias. Já aplicada inclusive em favor de homens com argumentos de caráter preconceituoso e estereotipado, a Lei Maria da Penha provocou reflexões sobre as causas das resistências desses setores. Sobre isso, comenta Campos (2008):

A relutância em aplicar a Lei Maria da Penha talvez possa ser explicada pelo desconhecimento da violência de gênero em nossa sociedade e pelo senso comum teórico dos juristas (Warat). Ao desconhecer que a violência de gênero é estruturante das relações hierarquizadas entre os sexos, os operadores do direito desconhecem que ela produz uma vulnerabilidade específica. É exatamente essa situação que torna a natureza da violência doméstica distinta de todos os demais delitos. Esse desconhecimento tem como consequência decisões inadequadas que acabam por sustentar a aceitação social da violência contra as mulheres.

As dificuldades de garantir uma cidadania plena às mulheres, sem violência e com direitos, se apresentam como um contínuo na história do Brasil e da região latino-americana. Segundo Abrazinskas e Lopes Gómes (2007), quando determinadas políticas públicas tocam no campo complexo da sexualidade e autonomia das mulheres, incluindo sua saúde física e psíquica, essas são trasladadas para o terreno da disputa de poder, no sentido de "quem manda mais", e onde, em geral, as questões democráticas têm sido burladas pela forte intromissão de elementos externos ao 
estado na política, como as religiões e crenças pessoais, mesmo em países relativamente laicos, como o Uruguai, país de onde falam.

Sobre a luta pelas delegacias especializadas desde 1984 muito já se escreveu e sistematizou no Brasil (BRASIL, 2004a; HERMANN, 2006), identificando-se dificuldades no processo de sua criação, status na estrutura policial, escassez e baixa qualidade quanto aos recursos humanos e materiais e limites de atuação, vinculadas, sobretudo, ao não reconhecimento dessa forma específica de violência, algo muito relacionado às crenças predominantes na sociedade. Ao longo das décadas de existência, a despeito de sua capacidade de disseminar a ideia da necessidade de punir a violência contra as mulheres, as delegacias foram numericamente pouco ampliadas, cobrindo menos de $10 \%$ dos mais de $5 \mathrm{mil} \mathrm{mu-}$ nicípios brasileiros. E já se sabe que para serem efetivas, precisam estar vinculadas a redes de atendimento complexas, com de centros de referência, casas abrigo, juizado especializado, defensoria pública e ministério público voltados para o tema, além de redes setoriais, como de segurança pública, saúde e assistência, e de um controle social efetivo que monitore e estimule sua existência e aprimoramento.

Na sua relação com a saúde, o trabalho com a violência de gênero encontra barreiras diferentes, como a visão fragmentada, embora assentadas em fundamentos semelhantes, acerca dos quais desejamos aprofundar neste trabalho, a fim de oferecer ao movimento de mulheres argumentos e alguns caminhos para a reflexão e elaboração de estratégias de advocacy, monitoramento e controle social e, quem sabe, a gestores, para a elaboração de políticas. Busca-se, também, contribuir para que o Observatório para a Implementação da Lei Maria da Penha reflita outras perspectivas além dos aspectos relativos à justiça e segurança. Para tanto, escolhemos enfatizar a violência sexual e saúde sexual e re- 
produtiva, com ênfase no acesso à atenção aos agravos ${ }^{4} \mathrm{e}$ a interseção de violência de gênero e HIV/Aids. (BRASIL, 1940)

Com a intenção de montar um panorama, utilizamos alguns estudos elaborados por pesquisadoras/es brasileiros e os resultados do levantamento de dados nacionais para um estudo multinacional, impulsionado pela campanha internacional denominada Women Won't Wait (Mulheres não esperam: acabemos com as epidemias Aids e a Violência Já) e apoiado pela agência das Nações Unidas para a Aids (Unaids). O panorama inicial é oferecido pelo Relatório Mundial sobre Violência e Saúde (OMS, 2002) e aportes de vários estudos brasileiros e internacionais.

\section{O que já se disse sobre violência e saúde}

Como uma importante referência para a busca de consenso científico sobre o tema, o Relatório Mundial sobre Violência e Saúde (OMS, 2002) foi elaborado a pedido do Secretario Geral da Organização das Nações Unidas (ONU), no início dos anos 2000, para respaldar estratégias em cada país e sensibilizar a opinião pública do planeta. Esse informe aborda em dois dos nove capítulos as violências com determinação de gênero e suas consequências para a vida das mulheres. ${ }^{5}$ A partir de evidências, é reconhecido que as mulheres abusadas física e sexualmente na infância ou na fase adulta desenvolvem mais problemas de saúde do que as outras mu-

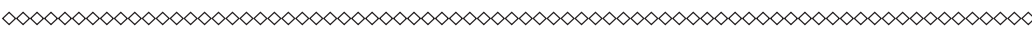

4 A previsão legal existe desde 1940, no Código Penal Brasileiro, Artigo 128.

5 A violência sexual tem um impacto profundo sobre a saúde física e mental. Além de causar lesões físicas, ela está associada a um maior risco de diversos problemas de saúde sexual e reprodutiva, com consequências imediatas e em longo prazo (4, 7 - 16). Seu impacto sobre a saúde mental pode ser tão sério quanto seu impacto físico, podendo ser também de longa duração $(17$ - 24). As mortes subsequentes à violência sexual podem se manifestar sob a forma de suicídio, infecção por HIV (25) ou assassinato - que pode ocorrer durante uma agressão sexual ou, posteriormente, como um assassinato "pela honra" (26). A violência sexual também pode afetar profundamente o bem-estar social das vítimas; em consequência dessa violência, as pessoas podem ser estigmatizadas e jogadas ao ostracismo por suas famílias e outras pessoas $(27,28)$. (OMS, 2002, p. 161) 
lheres, ficando mais predispostas ao adoecimento psíquico, ao desenvolvimento de comportamentos de risco, o que incluiria maior adesão ao tabaco, à inatividade física e abuso de álcool e drogas:

[...] o fato de ter um histórico de ser alvo de violência coloca a mulher em risco crescente de depressão, tentativas de suicídio, síndromes de dor crônica, distúrbios psicossomáticos, lesão física, distúrbios gastrintestinais, síndrome de intestino irritável, diversas consequências na saúde reprodutiva. (OMS, 2002, p. 102)

Ao abordar os impactos sobre a saúde reprodutiva, o informe da Organização Mundial da Saúde (2002, p. 103) relata que

[...] as mulheres que vivem com parceiros violentos passam por dificuldades para se proteger contra gravidez indesejada ou doenças. A violência pode levar diretamente à gravidez forçada ou a infecções sexualmente transmitidas, inclusive infecção por HIV, através do sexo forçado, ou ainda indiretamente, ao interferir na possibilidade de uma mulher usar contraceptivos, inclusive preservativos.

Outros trabalhos compilados pela OMS (2002) relacionam a violência doméstica com direitos reprodutivos ao identificarem que é mais comum em famílias com muitos filhos, levando a investigar se o elevado número de filhos foi a causa ou a consequência da violência, concluindo que, como esta começa em $80 \%$ dos casos nos primeiros anos de casamento, pode ser, na verdade, a causadora de gestações numerosas e não desejadas.

A OMS (2002) identificou ainda relações entre a violência durante a gravidez com o aborto espontâneo, a entrada tardia em cuidado pré-natal, bebês natimortos, parto e nascimento prematuros, lesão fetal, baixo peso ao nascer, uma das principais causas de morte infantil nos países emergentes e, por fim, a mortalidade materna.

Há evidências científicas de que a violência é responsável por até $16 \%$ das mortes maternas em países como a Índia, mas esses dados também são encontrados no Brasil, ainda que fora dos in- 
dicadores de mortalidade materna,${ }^{6}$ e em países desenvolvidos, como os Estados Unidos. (PORTO ALEGRE, 2009)

Em relação à saúde física, o Relatório da OMS (2002, p. 104) mostra que a violência pode levar a lesões, desde cortes e hematomas, até invalidez permanente e morte. De $40 \%$ a $72 \%$ de todas as mulheres que sofreram abuso físico de um parceiro em algum momento de sua vida, dizem os estudos de base populacional em que se assenta o informe que elas poderão sentir as consequências, sendo as mais comuns os "distúrbios funcionais”. Esses distúrbios frequentemente não apresentam uma causa médica identificável, sendo os mais comuns a síndrome de intestino irritável, fibromialgia, problemas gastrintestinais e diversas síndromes de dor crônica, os quais se vinculam ainda a históricos de abuso físico ou sexual. Acrescenta a esse relatório que as vítimas de abusos tendem a um funcionamento físico reduzido, mais sintomas físicos e, em casos de adoecimento, passam mais dias de cama do que as mulheres que não sofreram abuso.

Segundo a OMS, no campo da saúde mental tem sido identificada maior prevalência de depressão, ansiedade e fobias em mulheres em situação de violência por parte de seus parceiros do que as mulheres que não sofrem diretamente esses abusos. O mesmo ocorre em relação ao risco mais elevado de suicídio e tentativas de suicídio.

Esses adoecimentos frequentes podem condicionar à maior utilização ou demanda mais frequente dos serviços de saúde, elevando seus custos: ${ }^{7}$ em média, diz o estudo, as vítimas de violência de gênero passam por mais cirurgias, consultas médicas,

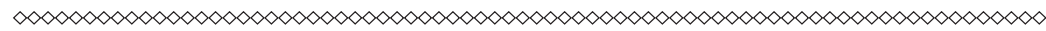

6 Em Porto Alegre, desde 2002, os homicídios de mulheres na gestação e em puerpério são a causa principal de mortes, embora esse dado não integre os índices de razão de morte materna.

7 O Banco Interamericano de Desenvolvimento patrocinou estudos sobre a magnitude e o impacto econômico da violência em seis países da América Latina. (OMS, 2002) Cada estudo avaliou os gastos resultantes de violência em serviços de assistência à saúde, aplicação da lei e serviços judiciários, bem como prejuízos intangíveis e prejuízos com a transferência de bens. Expresso como um percentual do Produto Interno Bruto (PIB), em 1997, o custo dos gastos com assistência à saúde, resultantes da violência, foi de 1,9\% do PIB no Brasil, $5 \%$ na Colômbia, 4,3\% em El Salvador, 1,3\% no México, 1,5\% no Peru e 0,3\% na Venezuela. 
internações em hospitais, idas a farmácias e consultas de saúde mental durante sua vida do que as que não são vítimas.

Como conclusão geral do estudo da OMS (2002), tem-se que: (1) a influência da violência pode durar muito tempo, mesmo depois de ter cessado; (2) quanto mais grave a violência, maior é o impacto sobre a saúde física e mental da mulher; (3) o impacto de diferentes tipos de violência e múltiplos episódios de violência parece ser cumulativo ao longo do tempo.

Também a Anistia Internacional vem abordando o tema e, segundo seus informes, a vida das mulheres em zonas mais pobres, favelas e de conflitos faz com que aumente a vulnerabilidade para a violência de gênero (NILO, 2008), ocorrendo a mesma elevação quando se tornam positivas para o vírus HIV. Também segundo Nilo (2008, p. 115), “[...] a violência e demais violações dos direitos humanos contra as mulheres e meninas podem ser a causa e consequência da infecção pelo HIV [...]", citando quatro situações: sexo forçado, medo da violência que dificulta a negociação do preservativo, abuso sexual na infância e compartilhamento do status sorológico como agravante do risco da violência.

Recentes achados brasileiros alertam para outras consequências ao demonstrar que os períodos de gestação e puerpério não isentam as mulheres de serem alvo de violências de gênero (BRASIL, 2002; VALONGUEIRO; Ludemir; Barreto, [200]; NEGRÃO, 2008), havendo escassas denúncias por parte das vítimas em razão dos fatores subjetivos, em especial o medo de ficarem sozinhas nesse momento da vida. (DURAND; SCHRAIBER, 2007) Assim, nos estudos sobre mortalidade materna, há um novo elemento a ser analisado, que relaciona o risco aumentado para a violência de gênero, podendo vir a alterar indicadores e resultados na razão de morte materna.

Na esteira das discussões internacionais, o Ministério da Saúde brasileiro passou a reconhecer, a partir do final da década de 1990, 
a violência como um problema que requer intervenções de caráter preventivo, bem como de tratamento após sua vivência, havendo norma técnica específica para violência sexual e uma lei de notificação obrigatória dos casos que chegam aos serviços de saúde.

A Política Nacional de Atenção Integral à Saúde da Mulher (BRASIL, 2004a) inclui nos objetivos gerais e estratégias promover a atenção às mulheres e adolescentes em situação de violência doméstica e sexual, organizando redes integradas, articulando com a prevenção às Doenças Sexualmente Transmíssiveis (DSTs) e promovendo ações preventivas. Desde 1998, atualizada em 2005 e 2012, vigora uma Norma Técnica, e em 2007 foi lançado um Plano de enfrentamento à feminização do HIV e outras DSTs, com enfoque de gênero, que na prática não foi incorporado como ampla estratégia e não chegou a estados e municípios.

Na realidade, apesar dos enormes avanços verificados no Brasil quanto ao reconhecimento do problema, alguns diagnósticos, cujas fontes são usuárias e ativistas, demonstram que a passagem das mulheres pelos serviços de saúde ainda é marcada por sofrimento e silêncio. Uma pesquisa acadêmica em parceria com uma organização de mulheres negras de Porto Alegre ouviu usuárias do Sistema Único de Saúde (SUS) num bairro pobre e populoso, concluindo que, em geral, profissionais não se dispõem a oferecer a escuta às vítimas em atendimento médico (MARIA MULHER, 2004), caracterizando omissão na atenção à saúde. Relatam as entrevistadas que uma pergunta a mais do profissional de saúde bastaria para que revelassem os contextos de violência de gênero, inclusive a violência sexual em suas vidas conjugais e afetivas, no entanto, a omissão e o silêncio colaboram para a persistência de fenômeno que se mescla com outras iniquidades, como o racismo institucional, a desigualdade econômica, o local de moradia e outras vulnerabilidades que repercutem na saúde física, mental, sexual e reprodutiva. 
Outro trabalho, coordenado por Meneghel e colaboradores (2011) para a identificação de rotas críticas percorridas por mulheres em Porto Alegre, revelou a fragmentação do atendimento como uma característica dessa atenção e posicionamento dúbio por parte de agentes públicos frente a esse problema, o que se confirmou em outro estudo no mesmo ano sobre uma avaliação das redes de atendimento nessa capital do Sul do Brasil. (NEGRÃO, 2011a) Esse trabalho mostrou a ausência de fluxos e redes de atendimento a mulheres em situação de violência cada vez mais invisíveis na estrutura do sistema de saúde e o esvaziamento de serviços especializados em violência de gênero e violência sexual em particular, retirando das mulheres a chance de serem ouvidas e atendidas.

Em relação à violência sexual, dois estudos da Universidade Estadual de Campinas (Unicamp) (FAÚNDES et al., 2000; FAÚNDES, 2008) fornecem bons elementos para essa análise: 0 primeiro, desenvolvido na região de Campinas e Sumaré, no estado de São Paulo, entrevistou 1838 mulheres de 15 a 49 anos, com queixas ginecológicas, das quais $54,9 \%$ revelaram ter mantido relações sexuais contra a sua vontade em algum momento da vida. Considerando que os traumas físicos, psicológicos, DSTs e gestações indesejadas já são elementos relativamente reconhecidos quando há violência sexual, o estudo comparou os exames de saúde das mulheres que viveram situações de violência com as que não haviam identificado tais situações. Constatou-se que, além da maior prevalência de irregularidades menstruais, dores pélvicas e dismenorreias, elas tinham, de acordo com a intensidade da pressão, coação ou violência nas relações sexuais, duas, três ou até quatro vezes mais falta de libido em relação às que não viveram violência. E a ausência de vontade de sexo variou de 2,9\% a 14,3\% entre os dois grupos. (FAÚNDES et al., 2000) 
Já o segundo estudo, resultado da parceria com a Federação Brasileira de Ginecologia e Obstetrícia (Febrasgo) e o Ministério da Saúde (FAÚNDES, 2008), revelou que dos 884 hospitais e pronto-socorros do Brasil que declaravam na época realizar todos os procedimentos preconizados pelas Normas Técnicas do Ministério da Saúde, 430 os realizavam de fato (48\%), e tão somente 107 de 807 haviam feito atendimentos completos nos últimos 10 a 14 meses que a pesquisa enfocou. Entre as razões identificadas, há elementos relacionados com gestão, tais como a falta de informação, capacitação, meios físicos e materiais, medicamentos e outros relacionados a crenças e opções pessoais dos profissionais, classificadas como objeção de consciência. Um estudo dessa magnitude torna transparente que a interface da saúde é uma falha no enfrentamento das consequências da violência na vida das mulheres, pois o acesso é condicionado a barreiras que grande parcela da sociedade não alcança. Evidencia-se também que o Código Penal e a Lei Maria da Penha estão sendo descumpridos no que tange ao atendimento às mulheres que se encontram nessa situação, persistindo um quadro de violação do direito humano à saúde e à dignidade, já observado há três décadas e que foi analisado por Talib e Citeli (2005).

Segundo a pesquisadora, quando a prefeitura de São Paulo inaugurou, em 1989, a atenção especializada para violência sexual, incluindo a interrupção da gestação, direito previsto no Código Penal Brasileiro, ${ }^{8}$ houve fortes reações contrárias. A permanência do serviço foi assegurada num amplo processo de defesa e no diálogo com a sociedade, daí porque resistiu, segundo Talib e Citeli (2005). O debate enfatizou entraves de ordem religiosa, legal, política, moral e judicial, e também sobre o caráter pioneiro e inovador do esforço. Ao recuperar a história de implantação

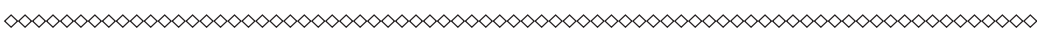
8 Art. 128, inciso II, segundo o qual não se pune o aborto nos casos de risco de vida da gestante e quando é fruto de estupro. (BASIL, 1940) 
do primeiro serviço, no Hospital Jabaquara de São Paulo, a autora lembra que, apesar do tratamento legal, rigoroso e de todos os cuidados técnicos para essa abordagem mais abrangente da violência, foram enfrentados adversários externos e internos poderosos que atuaram com todos os recursos disponíveis, como a mídia, medidas legais e tentativas de descrédito.

Dos anos de 2003 em diante, período em que o Ministério da Saúde atualizou protocolos, normatizou e passou à implementação da atenção à saúde sexual e reprodutiva das mulheres com o enfoque nos direitos humanos, é possível identificar um permanente campo de contenda, oriundo de diversos setores conservadores, em especial religiosos, com representantes no congresso nacional. A violência, por sua relação com a saúde, não tem ficado de fora do alvo. Segundo a ONG Cfemea, cuja atribuição é acompanhar as atividades na Câmara Federal e Senado relativas aos direitos das mulheres, cerca de 30 projetos contrários aos direitos sexuais e reprodutivos têm tramitado anualmente. Entre esses, os que propõem alterar o Código Penal, para extinguir com a não punibilidade do aborto em casos de estupro e a criação de ajuda financeira para mulheres, mantêm a gestação fruto de estupro como forma de inibir a decisão de interrupção e, ao extremo, o estatuto do nascituro que, em tese, coloca abaixo qualquer possibilidade de abortamento, mesmo aquela que resulta de violação. Dessa maneira, a violência sexual deixaria de ser considerada uma violação à liberdade sexual das mulheres e a gestação decorrente como obrigatória a todas as vítimas, como nos retrocessos havidos na Nicarágua e Honduras em anos recentes. (FLEISCHER, 2009)

Outras formas de impedir o acesso das mulheres, especialmente as jovens e adolescentes aos recursos tecnológicos existentes em defesa de sua saúde reprodutiva, são as iniciativas no interior do Brasil de impedir a distribuição da contracepção de emergência (ARILHA; LAPA; PISANESCHI, 2010) por meio de leis 
municipais. Cerca de 20 ações foram identificadas entre 2005 e 2008 apenas no estado de São Paulo, com repercussões na Câmara Federal, onde vários parlamentares, inicialmente liderados por Ângela Guadagnin, e posteriormente por Luis Bassuma e Henrique Afonso, incluíram essa proposta como parte da pauta da Frente Parlamentar Contra o Aborto. Assim, a ingerência das igrejas, católica, evangélica e outras, argumentando contra a legalização do aborto e mostrando as estreitas relações entre política e religião, impuseram uma discursividade negativa ao direito das mulheres e adolescentes vítimas de violência sexual ou de risco de gestação indesejada, de acessar uma tecnologia anticonceptiva disseminada em todo o mundo e reconhecida pela OMS.

O clima de ilegalidade e de dificuldades em acessar serviços tem gerado maiores sofrimentos às mulheres até os dias atuais. À custa de colocar a própria vida em risco e temerosas das consequências e estigmas

[...] muitas mulheres chegam aos serviços de saúde em processo de abortamento ou mesmo demandando o direito de realizar um aborto permitido por lei, vivem momentos difíceis, com sentimentos de solidão, angústia, ansiedade, culpa, autocensura, medo de falar, de ser punida, humilhada e a sensação de não poder engravidar novamente. (ARAÚJO; SIMONETTI, 2010)

Essa frequente ameaça aos direitos, desde o final da década de 1980 até os dias atuais, mostra que violência, na medida em que se vincula com saúde e corpo e implica uma tomada de decisão, traz os mesmos atores à cena: segmentos religiosos e conservadores que não reconhecem as mulheres como sujeitos de direito sobre suas decisões. Uma pesquisa sobre o tema do aborto na imprensa de quatro países entre 1998 a 2008, entre os quais o Brasil, identificou que violência de gênero é imediatamente relacionada com a autonomia das mulheres para decidir sobre seu corpo, pois as grandes polêmicas no período giraram em torno da pílula do 
dia seguinte, contracepção de emergência e mudanças no código penal, na medida em que as tentativas de descriminalização do aborto sequer têm chegado a instâncias de maior deliberação do Congresso. (DIDES; BENAVENTE, 2011)

A dimensão da violência como um grave problema de saúde pública relacionada com padrões culturais em disputa no campo político e das políticas públicas e que encontra bases de legitimidade na sociedade é assim corroborada. Também o episódio midiático de agressão da estudante universitária Geisy Arruda, ${ }^{9} \mathrm{em}$ 2009, deu mostras da elevada intolerância, mesmo entre jovens, em relação a mulheres que tentam romper com modelos estéticos e de comportamento e trouxe à tona inúmeras perguntas sobre o papel histórico do feminismo no questionamento de padrões culturais persistentes. Como escreveu Calligaris (2009): “[...] Em particular, eu acreditava que, depois de 40 anos de luta feminista, ao menos um objetivo tivesse sido atingido: o reconhecimento pelos homens de que as mulheres (também) desejam. Pois é, os fatos provam que eu estava errado."

Sinalizador da necessidade de mais ação política e da existência de mecanismos a serem usados pelas mulheres em seu favor, esse episódio também confirmou que a permanência de concepções morais retrógradas independe de classe social, escolaridade e mesmo sexo, já que outras mulheres ajudaram na agressão e que relações de gênero desiguais produzem violências de gênero até entre as próprias mulheres. E nos colocam a refletir sobre os padrões culturais na contemporaneidade, de um lado a exterioridade midiática, e de outro o moralismo e a condenação.

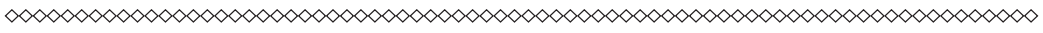

9 Caso de agressão sofrido por estudante da Universidade Bandeirante de São Paulo (Uniban), no interior de São Paulo, por colegas homens e mulheres da mesma faculdade, divulgado pelo Youtube e de grande repercussão em 2009. 


\section{A violência de gênero, HIV e Aids}

Cada vez mais falada e estudada em alguns países, a relação entre as epidemias de violência de gênero e de Aids passou a ser enfocada estrategicamente na agenda da Unaids, agência da ONU para a Aids, a partir de $2009,{ }^{10}$ partindo da constatação de que, atualmente, mulheres somam $50 \%$ de todas as pessoas vivendo com HIV no mundo, e em algumas regiões são duas vezes maiores seus riscos de contrair o vírus. Por razões biológicas somadas a fatores sociais, econômicos e culturais, tais como papéis de gênero, relações de poder desequilibradas, menor atenção no adoecimento e na prevenção e a aceitação pela sociedade da violência, inclusive a sexual, mulheres e meninas encontram-se em condições desfavoráveis em relação à sua saúde, segurança e autonomia. (UNAIDS, 2010) Em 2013, a Comissão sobre o Status da Mulher das Nações Unidas, em sua $57^{\text {a }}$ Reunião, abordando o tema da violência, incluiu em suas conclusões finais a abordagem da interseção com o HIV e a Aids, um marco que pode vir a fortalecer importantes estratégias em cada país. Um tema que parecia já incluído nas agendas de governos em realidade ingressa como uma diretriz para as políticas públicas de gênero 20 anos depois das primeiras denúncias.

A interseção de violência de gênero, HIV e Aids foi abordada pioneiramente de forma sistemática no Brasil por um estudo coordenado pela organização não governamental Gestos-Soropositividade, Comunicação e Gênero, de Recife, em 2008. Atuante nos temas de gênero, políticas e serviços nesse campo, impulsionou investigações e debates reveladores desse cruzamento entre as brasileiras, com base em entrevistas, estudos de caso e acompanhamento em serviços frequentados por mulheres vivendo com HIV.

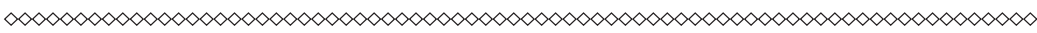

10 Agenda para o fortalecimento de ações para mulheres, meninas, igualdade de gêenero e HIV Plano Operacional para a Matriz de Resultados da Unaids. Fevereiro de 2010. 
Antes disso, em 2003, a tendência à feminização da epidemia tinha incitado nas feministas a construção de uma agenda, num trabalho que envolveu várias organizações preocupadas em incidir no conteúdo e direcionamento das políticas para prevenção e tratamento. (NILO, 2008) No entanto, a interseção de violência contra as mulheres e HIV/Aids ainda não havia encontrado um lugar-chave para vincular saúde com desigualdade de gênero.

Entre os principais achados do primeiro estudo, coordenado por Nilo (2008), é a revelação de que a experiência da violência de gênero pode estar diretamente vinculada à aquisição do HIV e que as discriminações e sofrimentos das pessoas que vivem com vírus se explicam, em grande parte, em razão do gênero. A desigualdade de poder como fator inibidor da negociação do sexo protegido, do estupro e da desinformação sobre os riscos de contaminação são panos de fundo de trajetórias marcadas por vulnerabilidades, inclusive violências continuadas e normalizadas na vida das mulheres. Em 2010, estudo em quatro países do Cone Sul (BIANCO; MARINO, 2010) levantou dados, políticas, legislações e ações efetivas para abordagem das duas epidemias, concluindo a falta de dados oficiais sobre infecções por HIV entre mulheres que passaram por situações de violência sexual, ausência ou insuficiência de programas governamentais que se articulem para mitigar ambas pandemias com enfoque integrador, nem financiamentos para programas de investigação ou intervenção. O Brasil foi citado como o único que tinha um plano para integrar estratégias, no entanto, sem avaliação de resultados. ${ }^{11}$

Em 2011, para montar um panorama internacional sobre o reconhecimento pelas políticas públicas das relações entre os dois temas, desenvolveu-se, com apoio de Unaids em 10 países, um levantamento sobre os conteúdos das políticas para a violência

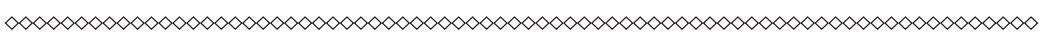

11 O Plano de Enfrentamento da Feminização da AIDS e outras DSTs foi lançado em 2007 e encerrado em 2012, sem ter grande impacto registrado. 
de gênero e para o enfrentamento da feminização da epidemia do HIV. Além de leis, normas, protocolos, o estudo buscou evidências para constatar se na implementação das políticas essas interfaces dialogam e propiciam estratégias eficazes. Nesse estudo, observou-se que uma elevada proporção das mulheres entrevistadas $(78,4 \%)$ experimentaram diferentes situações de violência ao longo de suas vidas. As formas mais habituais foram a psicológica $(68,9 \%)$, física $(55,6 \%)$, sexual $(36,3 \%)$ e abuso sexual na infância $(32,8 \%)$. Em geral, elas passaram por mais de uma forma de violência, indicando que essas manifestações se sobrepõem e se mesclam ao longo de suas vidas. (BIANCO; MARINO, 2010, p. 81)

O papel da dimensão de gênero como estruturante da subordinação social, econômica e política das mulheres ficou demonstrado nas vivências descritas, tanto pela sua vulnerabilidade ao HIV como à violência. Apesar das interseções das duas epidemias serem tão evidentes, apenas algumas mulheres conseguiram reconhecer seus vínculos. Neste sentido, a categoria da violência simbólica as ajudou a compreender essa ligação, conclui o estudo. (BIANCO; MARINO, 2010)

Ainda com a finalidade de esboçar um quadro atual das epidemias HIV e violência contra as mulheres no Brasil, em 2011 se realizou novo esforço na coleta de informações ${ }^{12}$ sobre as duas epidemias, seu perfil, impactos e legislação; programas e serviços, políticas integradas em programas e serviços que abordem efetivamente as necessidades das mulheres e meninas no contexto das epidemias; e redes, grupos e organizações de mulheres que atuam nas duas agendas, com o objetivo de promover o empoderamento e a liderança das mulheres e meninas para desenvolver uma res-

$\infty<\infty<\infty<\infty<\infty<\infty<\infty<\infty<\infty<\infty<\infty<\infty<\infty<\infty<\infty<\infty<\infty<\infty<\infty<\infty<\infty<\infty<\infty<\infty<\infty<\infty<\infty<\infty<\infty<\infty<\infty<\infty$

12 Monitoramento da Inclusão da Violência Contra Mulheres na Resposta à Aids no Âmbito Nacional e a Implementação da Agenda do UNAIDS para Mulheres e Meninas, 2011. Projeto coordenado por Alessandra Nilo (Gestos) e Telia Negrão (Coletivo Feminino Plural), com a seguinte equipe de pesquisa: Fernanda PivatoTussi, Juliana Cesar, Lea Epping, Neusa Heinzelmann, com insumos coletados em 10 regionais da Rede Feminista e organizações contatadas pela Gestos. 
posta ao HIV apropriada e efetiva, ou seja, numa perspectiva de gênero e direitos humanos.

Segundo os dados desse estudo, desde a identificação do primeiro caso de Aids no Brasil, em 1980, até junho de 2009, foram notificados 544.846 casos de AIDS no país, dos quais, 65,4\% entre homens e 34,6\% em mulheres. A taxa de prevalência (casos existentes) da infecção na população geral de 15 a 49 anos é de 0,61\%, sendo $0,41 \%$ entre as mulheres e $0,82 \%$ entre os homens. As investigações mostram que as prevalências de infecção pelo HIV no Brasil se apresentam da seguinte maneira: $0,6 \%$ na população de 15 a 49 anos de idade $(0,4 \%$ nas mulheres e $0,8 \%$ nos homens); $0,12 \%$ nos jovens do sexo masculino de 17 a 20 anos de idade; e $0,28 \%$ em mulheres jovens de 15 a 24 anos. Nas populações vulneráveis, as prevalências são mais elevadas e destacam-se aquelas entre usuários de drogas ilícitas $(5,9 \%)$, homens que fazem sexo com homens $(10,5 \%)$ e mulheres profissionais do sexo $(5,1 \%)$, inexistindo dados sobre população transexual.

A incidência dos casos (frequência de casos novos) de AIDS apresentou uma pequena oscilação nos últimos oito anos da pesquisa, tendo sido identificados, em média, 35 mil casos por ano. Essa oscilação justifica-se pelas diferenças regionais na forma como a AIDS se distribui, configurando, no país, diversos perfis da epidemia. Do total de casos notificados até junho de 2009, 65,4\% foram do sexo masculino (356.427 casos) e $34,6 \%$ do feminino (188.396 casos) e em 2007, a taxa de incidência foi de 22 por 100 mil habitantes entre homens e 13,9 por 100 mil habitantes entre mulheres. Entre jovens do sexo masculino, dos 13 aos 19 anos, a incidência no ano de 2005 é de 1,4; dos 20 aos 24 anos, 13,3\%. (BOLETIM..., 2009) 
Quanto às estimativas de orfandade, dados discrepantes e metodologias diversas não têm dado segurança às políticas públicas. ${ }^{13}$ Ainda que essas estimativas tenham sido calculadas com metodologias e em momentos distintos, haveria no Brasil, no início da década passada, entre 30 mil (1999), 34 mil (2001) e 27 mil (2002) órfãos maternos. (FRANÇA JUNIOR; DORING; STELLA, 2006)

Quanto à violência contra as mulheres, o levantamento encontrou muitos dados gerados ao longo dos anos, fruto de pesquisas de opinião e estimativas, inexistindo um sistema nacional oficial para registrar e unificar os casos, o que contribui para a persistência de uma grave lacuna a ser resolvida e que, apesar de perseguida pelos organismos de políticas para as mulheres, ainda não foi solucionada. Desta forma, estatísticas obtidas em serviços continuam sendo a principal fonte de informações, como a Central de Atendimento à Mulher - Ligue 180, que, em 2010, recebeu 108.546 relatos e é o principal indicador do governo para estimar a magnitude do problema.

Mas os dados do próprio governo demonstram o grau de dificuldade na construção de um sistema de informações e de indicadores, pois o Anuário Brasileiro de Segurança Pública de 2011, produzido pelo Fórum Brasileiro de Segurança Pública e Ministério da Justiça, enumera informações gerais sobre registros policiais, mas não desagrega as ocorrências por sexo, dando números absolutos e taxas, deixando a definição do sexo da vítima ao encargo da leitura de gênero.

Sendo ainda relevante a informação sobre violência sexual e sua relação com a saúde, a pesquisa constatou também que não existem dados sobre o acesso das mulheres vítimas de violência a serviços de saúde e que tenham recebido Profilaxia após Exposição

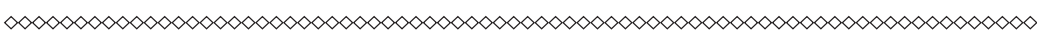

13 Na segunda edição do Dossiê Children on the Brink (Crianças no Limite) (2004), a Unaids, o Fundo das Nações Unidas para Infância (Unicef) e a United States Agency for International Development (Usaid) anunciaram que não fariam mais estimativas de órfãos por Aids para o Brasil, entre outros países. (ONU, 2004) 
Sexual (PEP) ou contracepção de emergência ou daquelas que receberam assessoramento legal ou atendimento psicológico. Embora os casos de violência contra a mulher sejam de notificação compulsória por lei, não foram encontrados registros nacionais.

A despeito das dificuldades para a obtenção de dados dentro dos sistemas públicos que possam demonstrar a relação entre as duas epidemias, é impressionante o número de pesquisas sobre o tema identificado pelo estudo. ${ }^{14}$ Sendo um dos mais relevantes o trabalho de Nilo (2008), que ladeia com cerca de 1340 artigos, teses, dissertações e pesquisas sobre violência e sobre HIV, segundo o levantamento realizado. No entanto, apesar de abundantes, menos de $10 \%$, estabelecem o nexo quando se trata de relacionar violência de gênero e HIV, de acordo com a busca realizada pela pesquisa em bancos nacionais, permanecendo o desafio de identificar essas vulnerabilidades e torná-las parte das preocupações das políticas públicas, das agendas sociais e da própria pesquisa.

Quanto às políticas e normas de saúde relativas à violência, o trabalho mapeou ainda os principais documentos, destacando a Norma Técnica de Prevenção e Tratamento dos Agravos Resultantes da Violência Sexual Contra Mulheres, Crianças e Adolescentes, a Política Nacional de Atenção Integral à Saúde da Mulher, Aspectos Jurídicos do Atendimento às Vítimas de Violência Sexual - Perguntas e Respostas para Profissionais de Saúde, Normas Técnicas para Padronização das Delegacias Especializadas de Atendimento à Mulher (DEAMs), Atenção Integral para Mulheres e Adolescentes em Situação de Violência Doméstica e Sexual - Matriz Pedagógica para a formação de redes, Protocolo Nacional para Atenção a Mulheres em Situação

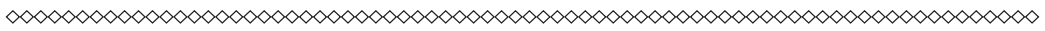

14 Foram buscados artigos acadêmicos/científicos brasileiros, escritos em português, publicados em Scielo (http://scielo.br). Dissertações de mestrado e teses de doutorado foram buscadas no Banco de Teses da Capes (http://capesdw.gov.br/capesdw). 
de Aborto e Pós Aborto, Atenção Humanizada ao Abortamento. (BRASIL, 2004a, b, 2009, 2010, 2011a, b, 2012)

Quanto aos documentos destinados às mulheres vivendo com HIV, não foi identificada a existência deste protocolo nacional, embora anunciada a intenção de realizá-lo até dezembro de 2011. Em relação à PEP, há um consenso destinado a profissionais de saúde com recomendações, um manual pós-exposição laboral ao HIV do Ministério da Saúde (2006) com recomendações para anticoncepção, no entanto, não se atrela à violência de gênero. Sobre as recomendações para o uso de Anticoncepção de Emergência, há clara menção à violência sexual. Nenhum documento destina-se a estabelecer especificamente a interseção entre violência de gênero e HIV e Aids, o que poderia significar, se existisse, uma ferramenta de orientação para o trabalho na área da saúde e também na área da violência contra as mulheres. Nesse sentido, destaca-se a importância do Plano Nacional de Enfrentamento à Feminização da Epidemia do HIV e outras DSTs, por identificar a violência como uma vulnerabilidade ao HIV e à Aids, instrumento de política que, apesar de seu aspecto inovador ao ser lançado, perdeu a potência ao longo dos anos, hoje invisível nos debates sobre as políticas públicas para a saúde e violência. Tem-se, pois, uma agenda em aberto para o trabalho a ser feito pelo movimento de mulheres e outros segmentos que atuam no controle social das políticas públicas no Brasil, que, vista de perto, aponta para o conceito de integralidade, uma bandeira das feministas da área da saúde e diretriz do Programa de Assistência Integral à Saúde da Mulher (PAISM) (1983) e reafirmado pela Política Nacional de Atenção Integral à Saúde da Mulher (PNAISM) (2004a, b), em vigor. 


\section{Agenda em aberto}

No Brasil, foi a Constituição Federal de 1988 que reconheceu a existência da violência contra as mulheres ao estabelecer a necessidade de proteção às vítimas de violência intrafamiliar; previu também a assistência à saúde pelo Estado através do $S U S,{ }^{15}$ o qual deve se submeter ao "controle social". Esse sistema de atenção à saúde, por sua vez, é concebido pelos princípios da universalidade, equidade e integralidade e sua implementação tem como base as diretrizes da hierarquização, descentralização, com direção única em cada esfera de governo e participação da comunidade. Dos princípios, a equidade é o elemento que ancora o enfrentamento de desigualdades, dentre as quais de gênero, entrecruzada com raça e etnia, orientação sexual, idade e deficiência, significando que grupos desiguais merecem tratamento diferenciado, pois têm necessidades diversas (REDE FEMINISTA DE SAÚDE, 2002), ao lado do princípio da integralidade, que orienta no sentido de que as pessoas sejam o centro da atenção e devam ser tratadas pelos serviços como um todo e não de forma fragmentada. Isso significa, em outras palavras, que todas as necessidades da população e dos indivíduos devem ser atendidas, nos aspectos da promoção, prevenção, tratamento e reabilitação. Pressupõe, ainda, a articulação da saúde com outras políticas públicas geradoras de qualidade de vida e melhoria dos níveis de saúde. (REDE FEMINISTA DE SAÚDE, 2002)

Segundo Clair Castilhos (2003, p. 52), “[...] dos três pilares do SUS - o controle social, a descentralização e a integralidade da atenção [...] - a integralidade é o princípio que não se cumpre”, pois, em sua avaliação, os profissionais de saúde em geral desconhecem

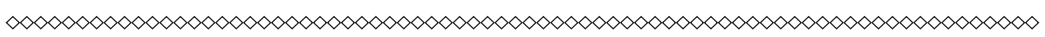

15 As leis n. 8.080/1990 e a n. 8.142/1990 são conhecidas como Leis Orgânicas da Saúde, pois institucionalizam SUS. A sua implantação dessas leis e a consolidação de seus princípios requerem um papel atuante de todos os envolvidos: gestores, profissionais e usuários. (BRASIL, 1990) 
o seu verdadeiro significado, situação que se mantém e continua desafiando a centralidade da atenção integral à saúde da mulher.

No entanto, para Castilhos (2008, p. 59), apesar da não implementação efetiva da política de saúde integral,

[...] o discurso sobre a saúde da mulher no interior das instituições de saúde começou a mudar e a ser entendido sob novas abordagens. É possível reconhecer que, mais que um programa, o PAISM foi uma filosofia política, um comportamento ideológico de valorização da mulher, um conjunto de estratégias políticas e programáticas.

A lei do SUS também estabelece o controle social das políticas e da atenção à saúde, da sua concepção, definição, financiamento e qualidade da assistência, tendo como locus principal os conselhos de saúde em cada nível de gestão, segundo a descentralização municipal, estadual e federal. O movimento de mulheres participa disputando o seu espaço, em parceria com o segmento de usuários e em diálogo com gestores e prestadores, buscando sinergia para afirmar a agenda de saúde e direitos sexuais e reprodutivos das mulheres. Em particular no campo da saúde sexual e reprodutiva, a Rede Feminista é uma das organizações que desde 1996, logo após a aprovação do Programa de Ação do Cairo (1994), passou a integrar uma estratégia internacional com o objetivo de visibilizar os efeitos positivos ou adversos na aplicação das legislações normativas, além de gerar políticas com perspectiva de gênero. (RED DE SALUD DE LAS MUJERES LATINOAMERICANAS Y DEL CARIBE, 2004) De 1996 a 2004, a Rede participou do Monitoramento do Programa de Ação de Cairo, que foi retomado de 2008 em diante. Um dos temas do seguimento de Cairo foi a violência sexual contra as meninas, avaliada por 33 indicadores. Destes, seis se direcionaram à área da saúde para verificar se a legislação previa a capacidade legal de profissionais de saúde para formularem a denúncia de violação, a existência de serviços de 
saúde, serviços gratuitos de assistência, normas técnicas de saúde, serviços de atenção primária, urgências e emergências capacitados, serviços implantados e a existência de normas e protocolos com perspectiva de gênero. (REDE FEMINISTA DE SAÚDE, 2004, p. 5) Essa experiência subsidiou campanhas e ações de advocacy no Brasil, estimulando o ativismo e o trabalho de controle social, cujos espaços principais são o Conselho Nacional de Saúde (CSN) e Conselho Nacional dos Direitos da Mulher (CNDM), nos níveis estadual e municipal.

Foi acreditando nessa metodologia de ação política que, na aprovação da Lei Maria da Penha, a Rede Feminista de Saúde propôs, ${ }^{16}$ antes mesmo de sua vigência, a criação de um observatório nacional que tivesse, entre outros indicadores de avaliação, a interface com a saúde das mulheres, sob a condução da sociedade civil, sugestão que acabou sendo acolhida pela Secretaria Especial de Políticas para a Mulher (SPM) e pelo CNDM. Passando a integrar o Observatório da Lei Maria da Penha (Observe), a entidade passou a elaborar argumentos para que, entre os indicadores do monitoramento, pudesse ser incluída a relação entre violência de gênero e a saúde das mulheres, dessa forma, criando as evidências para basear a ação do controle social.

O monitoramento da Lei Maria da Penha, em curso desde 2008, articulado com outras normas sobre violência e sobre saúde, em particular saúde sexual e reprodutiva, HIV e Aids, pode permitir a obtenção de uma visão integral da aplicação da legislação existente, assim como os impactos da violência na saúde de mulheres. Numa leitura sobre as causas de morbimortalidade de mulheres e especialmente de mortes evitáveis, como as maternas, nas quais a violência constitui uma das principais causas, obter-

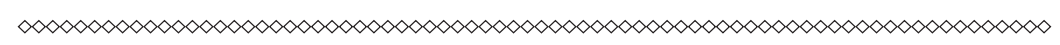

16 No período de 30 dias em que a Lei sancionada pelo presidente da República submeteu-se ao processo de possível arguição de constitucionalidade, a SPM/PR percorreu vários estados brasileiros para debates, inclusive com a Rede Feminista, em Porto Alegre, tendo recebido da Secretaria Executiva a proposta de criação do observatório. 
-se-ão referências indissociáveis para a vinculação de estratégias de prevenção à violência, como as de saúde, da mesma forma que estudos recentes demonstram a presença da violência na infecção de mulheres pelo HIV. Os dados abordam dois aspectos para a garantia da vida e da qualidade de vida das mulheres, que não se separam na vida real.

Nessa perspectiva, ampliam-se as possibilidades de inserir o tema da violência de gênero nas demais agendas da sociedade, como os conselhos de saúde, conselhos de direitos humanos, comitês de morte materna, fóruns, observatórios, assim como de reunir forças para a elaboração de informes, dossiês, capacitações, permitindo o advocacy qualificado e a incidência social e política. Ao caracterizar aqui a violência contra as mulheres como uma questão de saúde publica, de justiça e de direitos humanos, se ingressa também numa disputa de espaço na agenda do controle social e também na ação do monitoramento realizado pelo movimento de mulheres, em parceria com universidades e com outros movimentos, como o movimento de luta contra a AIDS.

Em seus primeiros anos de existência, o projeto Observe enfatizou a avaliação da implementação da Lei Maria da Penha no tocante à segurança e justiça, dois aspectos mais visíveis no amplo espectro da impunidade à violência contra as mulheres no Brasil. A impunidade que, ao persistir, mais naturaliza e banaliza as relações marcadas pela desigualdade de poder, rebaixa a cidadania e a autoestima das pessoas afetadas. Foi analisando as DEAMS, pelo papel estratégico que jogam na rede de atendimento, e os Juizados Especiais de Violência Doméstica, dois mecanismos para interromper o curso das violências e alguns elementos da rede de atendimento, que se produziram importantes argumentos para a luta do movimento de mulheres por políticas públicas.

Os resultados da coleta de dados e estudos de caso desse observatório revelam resistências culturais e políticas, dificuldades 
de disputa de recursos, baixa prioridade para o tema das relações de gênero no estado brasileiro, conservador, patriarcal e retrógrado em muitos aspectos. Indicam a existência de poucas redes de atendimento, serviços isolados e baixa compreensão do problema como obstáculos à sua eficácia. Há enormes desafios a serem superados quando menos de $10 \%$ dos municípios brasileiros dispõem de políticas especializadas.

Tendo em vista que das diversas experiências nacionais de monitoramento o Observe é a primeira no contexto da nova legislação; e considerando que uma das inovações da Lei Maria da Penha é a interface com a saúde-lei (art. $9^{\circ}$ ), alguns caminhos podem ser traçados em direção ao monitoramento dessa interseção e em específico, a contaminação por HIV. (BRASIL, 2006) Um deles pode ser a articulação dessa lei com as ações previstas na Política Nacional de Atenção Integral à Saúde da Mulher, com os eixos prioritários estabelecidos no atual Plano Nacional de Políticas para as Mulheres (BRASIL, 2011), a rearticulação do Plano de Enfrentamento da Feminização da Epidemia de DSTs, HIV e AIDS, hoje abandonado com as Normas Técnicas para a Prevenção dos Agravos da Violência Sexual Contra a Mulher e de Atenção Humanizada às Mulheres em Situação de Abortamento e com a Notificação Compulsória nos serviços de saúde (Lei n. 10.778). (BRASIL, 2003) Assim, seria possível a potencialização dessas ações: se políticas para a violência agregassem uma investigação sobre as relações com a saúde, inclusive com a Aids, se a atenção na linha de cuidados da saúde observasse as relações com situações de violência vividas, se a atenção à violência sexual de fato fizesse a investigação de de uma infecção e reinfecção pelo HIV e se a atenção à saúde das mulheres adotasse visão integral (inclusive de saúde mental) e de gênero na abordagem das causas de adoecimento das mulheres. 
Como a adoção desse enfoque de integralidade e de gênero resulta de um processo de aprendizado, torna-se pertinente ao controle social da saúde e das políticas para as mulheres o monitoramento quanto à capacitação da saúde, se vem sendo preparada e dotada de meios para acolher, atender e encaminhar mulheres em situação de violência; a existência de ações de qualificação de profissionais para a utilização de protocolos; a implementação da Norma Técnica de Prevenção aos Agravos da Violência Sexual Contra Adolescentes e Mulheres, realizando os procedimentos e insumos previstos; o cumprimento da Notificação Compulsória nos serviços de saúde (BRASIL, 2003); a articulação de serviços para a atenção à mulher em situação de violência com ações de prevenção das DSTs, HIV e AIDS; a atenção especializada na rede de atendimento, com articulação intra e intersetorial, com escuta qualificada, informação, orientação, apoio psicológico individual e em grupo e encaminhamento com referência e contrarreferência; a existência de ações de saúde em equipamentos das redes, como centros de referência, casas-abrigo e unidades sanitárias destinadas à abordagem integral do problema; e, por fim, se há medidas para informar às mulheres sobre seus direitos e à sociedade sobre seu papel como agentes de transformação.

\section{Algumas conclusões}

Estudo provocado pela Organização Mundial da Saúde desde 2002 alerta para as implicações da violência de gênero na saúde pública, apontando a necessidade de medidas preventivas e de atenção às vítimas, de forma a reduzir os impactos negativos na vida e na qualidade de vida das mulheres de todas as idades. No entanto, esse aspecto ainda é pouco reconhecido no Brasil, pois na maioria das vezes não se realizam encaminhamentos das instâncias jurídico-legais e de segurança para a área da saúde, com 
exceção dos casos de estupro, em que se procede ao exame de corpo de delito. Essa omissão resulta em revitimização das mulheres pela violação ao seu direito à saúde e aos direitos sexuais e reprodutivos. Por sua vez, serviços de saúde, especializados ou não, têm resistências em abordar a questão da violência, por desconhecimento e pelas implicações decorrentes.

As políticas de saúde para as mulheres, em especial as normas técnicas que articulam violência e saúde, não têm sido monitoradas e o controle social sobre elas é ainda insignificante na agenda dessas instâncias. Onde são aplicadas, as políticas enfrentam limitações de toda ordem, entre as quais o desconhecimento, a alegação de objeção de consciência por parte de médicos, quando se omitem na prescrição de anticoncepção de emergência ou para realizar a interrupção da gestação nos casos previstos em lei. Há pressões políticas para impedir a oferta de todos os recursos disponíveis. O tema da violência suscita o desejo por parcela da sociedade de impedir que exerçam seus direitos sexuais e reprodutivos com autonomia. Antes mesmo de acessarem as redes, as mulheres não encontram acolhimento no sistema de saúde para apresentar situações de desconforto, ficando invisíveis aos olhos das redes, que deveriam estar bem abertos. E os sistemas de exclusão e marginalização, sejam de gênero, sociais, étnico-raciais, etários, ou das escolhas sexuais, mais impõem suas perversidades àquelas com menor voz. Na prática, negam o direito à saúde como parte dos direitos humanos, violam-se os direitos sexuais e os direitos reprodutivos das mulheres, negligencia-se a saúde mental, promove-se a estigmatização. Acrescente-se a isso a condição de soropositividade ao HIV e o desenvolvimento da Aids, quando mais se fragilizam e vulnerabilizam as mulheres.

O monitoramento da Lei Maria da Penha tem sido uma importante motivação para o controle social das políticas contra a violência, no entanto, deve ser ampliado com novos olhares para 
que se obtenha a real dimensão das lacunas na atenção às mulheres e se possa oferecer argumentos para sensibilizar novos setores quanto à prevenção, punição e eliminação da violência de gênero. Mas, sobretudo, é preciso abordar a dimensão de saúde na violência contra as mulheres, inseri-la entre os direitos humanos, assegurando a vida e a qualidade de vida, sem estigmas e discriminações. A visão integral da violência é o reconhecimento das mulheres como seres integrais, autônomos e com direitos.

\section{Referências}

ABRAZINSKAS, L.; LOPES GÓMES, A. (Coord.). Aborto em debate: dilemas y desafios del Uruguay democrático. Montevidéu: Mysu, 2007.

ARAUJO, M. J. Ou fazer uso de misoprostol mulheres casca. In: REDE FEMINISTA SAÚDE. Direitos não Reprodutivos Brasil. Porto Alegre, 2010. (Trilhas de Saúde das Mulheres dois Direitos Sexuais e Reprodutivos Direitos; 1)

ARILHA, M.; LAPA, T. S.; PISANESCHI, T. C. Contracepção de emergência no Brasil e América Latina: dinâmicas políticas e direitos sexuais e reprodutivos. São Paulo: Oficina Editorial, 2010.

BIANCARELLI, A. Assassinatos de mulheres em Pernambuco. São Paulo: Publisher Brasil/ IPG, 2006.

BIANCO, M.; MARINO, A. Dos caras de una misma realidad: violência hacialas mujeres $y$ VIH/SIDA en Argentina, Brasil, Chile y Uruguay, evidencias y propuestas para lareorientación de las políticas públicas. Buenos Aires: Fundación para El Estudio e Investigación de La Mujer, 2010.

BOLETIM Epidemiológico, Brasília, DF: Ministério da Saúde, v. 4, n. 1, 2008-2009. Disponível em: <http://www.aids.gov.br/sites/default/ files/Boletim2010.pdf $>$. Acesso em: 2015.

BRAGA, K.; NASCIMENTO, E.; DINIZ, D. (Org.). Bibliografia Maria da Penha: violência contra a mulher no Brasil. Brasília: Letras Livres, Anis/ SPM, 2009.

BRASIL. Aspectos jurídicos do atendimento às vítimas de violência sexual: perguntas e respostas para profissionais de saúde. 2. ed. Brasília: 
Ministério da Saúde, 2011a. Disponível em: <http://bvsms.saude. gov.br/bvs/publicacoes/aspectos_juridicos_atendimento_vitimas_ violencia_2ed.pdf >. Acesso em: 2015.

BRASIL. Atenção integral para mulheres e adolescentes em situação de violência doméstica e sexual: matriz pedagógica para formação de redes. Brasília, DF: Ministério da Saúde, 2009. Disponível em: <http:// bvsms.saude.gov.br/bvs/publicacoes/atencao_mulheres_adolescentes_ matriz_pedagogica.pdf>. Acesso em: 2015.

BRASIL. Atenção humanizada ao abortamento: norma técnica. 2.ed. Brasília, DF: Ministério da Saúde, 2011b. Disponível em: <http://bvsms. saude.gov.br/bvs/publicacoes/atencao_humanizada_abortamento_ norma_tecnica_2ed.pdf>. Acesso em: 2015.

BRASIL. Código Penal. Brasília, DF: Senado Federal, 1940. Disponível em: <http://www.planalto.gov.br/ccivil_03/decreto-lei/Del2848. htm $>$. Acesso em: 2015.

BRASIL. Estudo da mortalidade materna de mulheres de 10 a 49 anos. Brasília, DF: Ministério da Saúde; OPAS, 2002. Mimeo.

BRASIL. Lei n. 8.080, de 19 de setembro de 1990. Dispõe sobre as condições para a promoção, proteção e recuperação da saúde, a organização e o funcionamento dos serviços correspondentes e dá outras providências. Disponível em: <http://www.planalto.gov.br/ ccivil_03/leis/L8080.htm>. Acesso em: 2015.

BRASIL. Lei $n$. 8.142, de 28 de dezembro de 1990. Dispõe sobre a participação da comunidade na gestão do Sistema Único de Saúde (SUS) e sobre as transferências intergovernamentais de recursos financeiros na área da saúde e dá outras providências. Disponível em: <http://www. planalto.gov.br/ccivil_03/leis/L8142.htm>. Acesso em: 2015.

BRASIL. Lei n. 10.778 de 24 de novembro de 2003. Notificação Compulsória da Violência nos serviços de saúde. Disponível em: <http:// www.planalto.gov.br/ccivil_03/leis/2003/L10.778.htm>. Acesso em: 2015.

BRASIL. Lei n. 11.340, de 7 de agosto de 2006. Cria mecanismos para coibir a violência doméstica e familiar contra a mulher. Disponível em: <http://www.planalto.gov.br/ccivil_03/_ato2004-2006/2006/lei/ 111340.htm>. Acesso em: 19 abr. 2015.

$\neg$ BRASIL. Lei n. 12.845, de 1 de agosto de 2013. Dispõe sobre o atendimento obrigatório e integral de pessoas em situação de violência 
sexual. Disponível em: <http://www.planalto.gov.br/ccivil_03/_ ato2011-2014/2013/lei/112845.htm>. Acesso em: 19 abr. 2015.

BRASIL. Norma técnica para padronização das Delegacias Especializadas de Atendimento à Mulher (DEAMs). Brasília, DF: Ministério da Justiça, 2010. Disponível em: <http://www.spm.gov. br/lei-maria-da-penha/lei-maria-da-penha/norma-tecnica-depadronizacao-das-deams-.pdf>. Acesso em: 2015.

BRASIL. Pacto nacional de enfrentamento à violência contra a mulher. Brasília, DF: Secretaria Especial de Políticas para as Mulheres, 2007.

BRASIL. Perfil organizacional das Delegacias Especiais de Atendimento à Mulher. Brasília, DF: Ministério da Justiça, 2004c. Disponível em: <http://www.agende.org.br/docs/File/dados_ pesquisas/violencia/Pesquisa $\% 20$ Perfil $\%$ 20DEAMs $\% 20-\% 20$ SENASP\% 202004.pdf >. Acesso em: 2015.

BRASIL. Pesquisa Nacional de Demografia e Saúde da Criança e da Mulher (PNDS). Brasília, DF: Ministério da Saúde, 2008.

BRASIL. Plano nacional de políticas para as mulheres. Brasília, DF: SPM, 2011c. Disponível em: <http://www.spm.gov.br/assuntos/pnpm>. Acesso em: 2015.

BRASIL. Prevenção e tratamento dos agravos resultantes da violência sexual contra mulheres e adolescentes: norma técnica. 3.ed. atual. e ampl. Brasília, DF: Ministério da Saúde, 2012. Disponível em: <http:// bvsms.saude.gov.br/bvs/publicacoes/prevencao_agravo_violencia_ sexual_mulheres_3ed.pdf >. Acesso em: 2015.

BRASIL. Programa de Assistência Integral à Saúde da Mulher (PAISM). Brasília, DF: Ministério da Saúde, 1983.

BRASIL. Política nacional de atenção integral à saúde da mulher: princípios e diretrizes. Brasília, DF: Ministério da Saúde, 2004a.

BRASIL. Política nacional de atenção integral à saúde da mulher: Plano de Ação 2004- 2007. Brasília, DF: Ministério da Saúde, 2004b.

BRASIL. Política nacional de atenção integral à saúde da mulher: princípios e diretrizes. Brasília, DF: Ministério da Saúde, 2011d. Disponível em: <http://bvsms.saude.gov.br/bvs/publicacoes/politica nacional_mulher_principios_diretrizes.pdf >. Acesso em: 2015.

CAMPOS, C. H. de. Maria da Penha: lei protege as mulheres na medida necessária. Boletim de notícias Conjur, 22 ago. 2008. Disponível em: 
<http://www.conjur.com.br/2008-ago-22/lei_protege_mulheres_ medida_necessaria $>$. Acesso em: 19 abr. 2015.

CAMPOS, C. H. (Coord.) Da guerra à paz: os direitos humanos das mulheres: instrumentos internacionais de proteção. Porto Alegre: Themis, 1997. p. 183-192.

CALligARIS, C. A turba da Uniban. Agência Patrícia Galvão, nov. 2009. Disponível em: <http: / /agenciapatriciagalvao.org.br/wp-content/ uploads/2009/11/folhasp051109.pdf >. Acesso em: 2015.

CASTILHOS, C. A presença da mulher no controle social das políticas de saúde. In: REDE FEMINISTA DE SAÚDE. Anais da capacitação de multiplicadoras em controle social das politicas de saúde. Belo Horizonte: Mazza, 2003. p. 33-51.

CASTILHOS, C. C. Saúde da mulher e o controle social no Brasil em tempos de neoliberalismo. R. Saúde públ. Santa Cat., Florianópolis, v. 1, n. 1, jan./jun. 2008.

COLAS, O. et al. Aborto legal por estupro - primeiro programa público do país. Revista Bioética, Brasília, DF, v. 2, n. 1, 1994. Disponível em: <http://revistabioetica.cfm.org.br/index.php/revista_bioetica/article/ view/447/330 >. Acesso em: 2015.

FLEISCHER, S. (Org.). Vozes latino-americanas pela legalização do aborto. Brasília, DF: CFEMEA, 2009.

DIDES, C.; BENAVENTE, M. C.; SAEZ, I. (Org.). Dinâmicas politicas sobre aborto em latinoamerica: estudio de casos. Santiago, Chile: Flacso, 2011.

DURAND, J.; SCHRAIBER, L.Violência na gestação entre usuárias de serviços públicos de saúde de São Paulo - prevalência e fatores associados. Rev. bras. epidemiol., São Paulo, v. 10, n. 3, set., 2007.

FAÚNDES, A. Avaliação da aplicação das normas sobre violência sexual nos serviços de saúde do Brasil. In: FÓRUM INTERPROFISSIONAL DE VIOLÊNCIA SEXUAL E ABORTO LEGAL. São Luis, 2008. Anais....São Luis: CEMICAMP; FEBRASGO, 2008.

FAÚNDES, A. et al. O risco para queixas ginecológicas e disfunções sexuais segundo história de violência sexual. Rev. Bras. Ginecol. Obstet., Rio de Janeiro, v. 22, n. 3, p. 153-157, abr. 2000.

FRANÇA JUNIOR, I.; DORING, M.; STELLA, I. Crianças órfãs e vulneráveis pelo HIV no Brasil: onde estamos e para onde vamos? Rev. 
Saúde Pública, n. 40, p. 23-30, 2006. Disponível em: <http://www. scielo.br/pdf/rsp/v40s0/05.pdf >. Acesso em: 21 abr. 2015.

FUNDACIÓN PARA ESTUDIO E INVESTIGACIÓN DE LA MUJER (FEIM); BIANCO, M. (Coord.). Violencia contra las mujeres $y$ VHI/Sida en quatro países del Mercosur: estadísticas, políticas públicas, legislación y estado del arte. Buenos Aires, 2009.

HEISE, L.; PITANGUY, J.; GERMAIN, A. (Org.). Violence against women: the hidden health burden. Washington: Banco Mundial, 1994.

HERMANN, J. A violência contra a mulher em números: dificuldades e desafios. In: LIBARDONI, M.; LEOCÁDIO, E. (Org.). O desafio de construir redes de atenção as mulheres em situação de violência. Brasília: Agende, 2006. p. 91-112.

LOURO, G. L. Gênero, sexualidade e educação: uma perspectiva pósestruturalista. 6.ed. Petrópolis: Vozes, 1997. p. 14-36.

MARIA MULHER. Mulheres em situação de violência doméstica e a incidência do HIV/Aids. Porto Alegre, 2004. Mimeo.

MENEGHEL, S. N. et al. Rotas críticas de mulheres em situação de violência: depoimentos de mulheres e operadores em Porto Alegre, Rio Grande do Sul, Brasil. Cad. Saúde Pública, São Paulo, Rio de Janeiro, v. 27, n. 4, p. 743-752, abr., 2011.

NEGRÃO, T. Aborto no Brasil: luzes e sombras nas vozes de atores e atrizes. In: DIDES, C.; BENAVENTE, M. C.; SAEZ, I. (Org.). Dinâmicas politicas sobre aborto em latinoamerica: estudio de casos. Santiago, Chile: Flacso, 2011a.

NEGRÃO, T. Diagnóstico das políticas públicas para mulheres, crianças, adolescentes e idosos no município de Porto Alegre. Porto Alegre, 2011b. Mimeo.

NEGRÃO, T. La violéncia de género es un indicador de muerte materna. Revista Mujer e Salud, Santiago, n. 2-3, p. 8-14, 2008.

NEGRÃO, T. Nós e rupturas da rede de apoio à mulher. In: STREY, M.; AZAMBUJA, M.; JAEGER, F. (Org.). Violência, gênero e políticas públicas. Porto Alegre: EDIPUCRS, 2004. p. 215-258.

NEGRÃO, T.; PRÁ, J. Conexões, rupturas e capital social de gênero. Revista Debates, Porto Alegre, v. 1, n. 1, dez., 2005. 
NILO, A. (Org.). Mulher, violência e AIDS: explorando interfaces. Recife: Gestos, 2008. p. 107-126.

ORGANIZAÇÃO DOS ESTADOS AMERICANOS (OEA). Convenção de Belém do Pará. Pará, 1994. Disponível em: <http://www.cidh.org/ Basicos/Portugues/m.Belem.do.Para.htm>. Acesso em: 20 abr. 2015. ORGANIZAÇÃO DOS ESTADOS AMERICANOS (OEA). Declaração de Direitos Humanos de Viena. Viena, 1993. Disponível em: <http://www. pge.sp.gov.br/centrodeestudos/bibliotecavirtual/instrumentos/viena. htm>. Acesso em: 2015.

ORGANIZAÇÃO DAS NAÇÕES UNIDAS (ONU). Convenção sobre a eliminação de todas as formas de discriminação contra a mulher. In: PIOVESAN, F.; PIMENTEL, S. (Org.). Direitos humanos e o direito constitucional internacional. São Paulo: Saraiva, [20--].

ORGANIZAÇÃO NAÇÕES UNIDAS (ONU). Convenção sobre a eliminação de todas as formas de discriminação contra a mulher. [S.l.]: ONU Mulheres, 1979. Disponível em: <http://www.pge.sp.gov. $\mathrm{br} /$ centrodeestudos/bibliotecavirtual/instrumentos/discrimulher. htm>. Acesso em: 2015.

ORGANIZAÇÃO DAS NAÇÕES UNIDAS (ONU). Plano básico para proteção, cuidado e apoio a órfãos e crianças vulneráveis vivendo em um mundo com HIV e AIDS. Unicef, 2004. Disponível em: <http:// www.unicef.org/aids/files/Framework_Portu.pdf >. Acesso em: 2015. ORGANIZAÇÃO DAS NAÇÕES UNIDAS (ONU). Poner fin a la violência contra mujer: de las palabras a los hechos. Hamburgo: World Future Council, 2014.

ORGANIZAÇÃO MUNDIAL DA SAÚDE (OMS). Relatório mundial sobre violência e saúde. Genebra: OMS, 2002.

PORTO ALEGRE (Prefeitura). Comitê Municipal de estudos e prevenção da mortalidade materna de Porto Alegre: relatório de mortalidade materna de 2009. Porto Alegre, 2009. Disponível em: <http:// lproweb.procempa.com.br/pmpa/prefpoa/sms/usu_doc/relatorio_ mortalidade_materna_em_porto_alegre_em_2009.pdf >. Acesso em: 2015 . 
RED DE SALUD DE LAS MUJERES LATINOAMERICANAS Y DEL CARIBE (RSMLAC). Atenea: el monitoreo como práctica ciudadana de las mujeres. Santiago: UNFPA, 2004.

RED DE SALUD DE LAS MUJERES LATINOAMERICANAS Y DEL CARIBE (RSMLAC). Basta de Impunidad. Observatório de Feminicídio em México. Entrevista com Maria de la Luz Estrada. Revista Mujer Salud, Santiago, n. 1, 2008.

REDE DE SAÚDE DAS MULHERES LATINOAMERICANAS E DO CARIBE (RSMLAC). Campanha Ponto final na violência contra mulheres e meninas: análise situacional. Porto Alegre, 2009.

REDE FEMINISTA DE SAÚDE. Controle social, uma questão de cidadania: saúde é assunto para mulheres. Florianópolis: Fundação Ford, 2002.

REDE FEMINISTA DE SAÚDE. Dossiê violência contra a mulher: um problema que afeta toda a sociedade. Recife, 2001. Disponível em: <http://monitoramentocedaw.com.br/wp-content/ uploads/2013/08/231895012-Dossie-Violencia-Contra-a-Mulher.pdf > . Acesso em: 2015.

REDE FEMINISTA DE SAÚDE. Dossiê: violência contra mulheres e meninas. Porto Alegre, 2005. Disponível em: <http://www. campanhapontofinal.com.br/download/new_23.pdf>. Acesso em: 2015. REDE FEMINISTA DE SAÚDE. Igualdade de gênero e HIV/Aids: uma política por construir. Florianópolis: UNIFEM, 2003.

REDE FEMINISTA DE SAÚDE. O monitoramento da Plataforma de Ação da Conferencia sobre População e Desenvolvimento no Brasil. [Florianópolis], 2004.

REDE FEMINISTA DE SAÚDE. Marcos de saúde da mulher dos direitos sexuais e direitos reprodutivos. In: REDE FEMINISTA DE SAÚDE.

Ferramentas para ação politica das mulheres: Projeto Trilhas de Saúde das Mulheres. Porto Alegre, 2008.

SAFFIOTI, H. I. Gênero, patriarcado e violência. São Paulo: Fundação Perseu Abramo, 2004.

SIMONETTI, C; SOUZA, L; ARAÚJO, M. J. de O. Dossiê A Realidade do aborto inseguro na Bahia: a ilegalidade da prática e seus efeitos na saúde das mulheres em Salvador e Feira de Santana. Salvador: IMAS, 
2010. Disponível em: <http://www.clacaidigital.info:8080/xmlui/ handle/123456789/51>. Acesso em: 2015

TALIB, R.; CITELI, M. Serviços de aborto legal em hospitais públicos brasileiros (1989-2004): dossiê. São Paulo: Católicas pelos Direitos de Decidir, 2005.

STREY, M. Violência de gênero: uma questão complexa e interminável. In: STREY, M.; AZAMBUJA, M.; JAEGER, F. P. (Org.). Violência, gênero e políticas públicas. Porto Alegre: EDIPUCRS, 2004. p. 13-44.

VALONGUEIRO, S.; LUDEMIR, A.; BARRETO, T. (Org.). Violência na gravidez: determinantes e conseqüências para a saúde reprodutiva, saúde mental e resultados perinatais. Pernambuco: Universidade Federal de Pernambuco, [200-].

VENTURE, G.; RECAMÁN, M.; OLIVEIRA, S. (Org.). A mulher brasileira nos espaços públicos e privados. São Paulo: Fundação Perseu Abramo, 2004.

UNAIDS. A Onu e a resposta à Aids no Brasil. 2010. Disponível em: $<$ http://www.unaids.org.br/〉. Disponível em: 22 ago. 2015. 


\title{
A SEGURANÇA PÚBLICA NO ATENDIMENTO ÀS MULHERES uma análise a partir do Ligue $180^{1}$
}

\author{
Alinne de Lima Bonetti \\ Luana Pinheiro \\ Pedro Ferreira
}

\section{Introdução}

Foi na década de 1980, sob o mote “quem ama não mata”, que o movimento feminista conseguiu finalmente reconhecer que a violência contra as mulheres, em especial a de caráter doméstico e conjugal, constituía-se em grave problema social e que necessitava, portanto, de intervenção do Estado, extrapolando as fronteiras militantes. (HEILBORN; SORJ, 1999) Em meio às inúmeras ações, análises e estudos sobre o tema, em 1985 foi criada a primeira experiência de política de segurança pública voltada para o combate à violência doméstica (PASINATO; SANTOS, 2008): a Delegacia 
de Defesa da Mulher, em São Paulo. (DEBERT; GREGORI, 2002; VIEIRA, 2007; PASINATO; SANTOS, 2005) Criada com o objetivo de "oferecer atendimento às mulheres em situações de violação de direitos, quaisquer que fossem" (IPEA, 2009a, p. 17), a experiência de criação desse tipo de instituição representou, naquele momento, praticamente um sinônimo de política pública de segurança para as mulheres.

Ao longo das últimas décadas, as Delegacias Especializadas de Atendimento à Mulher (DEAMs) se multiplicaram por todo o país e passaram por diferentes transformações, sendo foco de atenção de inúmeros estudos acadêmicos que objetivavam compreender os meandros do seu funcionamento. (SOARES, 1999; MUNIZ, 1996; CARRARA; VIANNA; ENNE, 2002; MACHADO, 2002; RIFIOTIS, 2004) Da mesma maneira, as políticas públicas de segurança voltadas para o enfrentamento da violência contra as mulheres foram passando por transformações nesse período. Desde a década de 1980 e até meados dos anos 2000, as políticas enfocaram a dimensão do combate, cujo eixo estava na "preocupação em possibilitar um atendimento emergencial às mulheres vítimas de violência e [na] realização de campanhas para alterar as percepções sobre esse fenômeno." (IPEA, 2007, p. 248) Naquele momento, os investimentos eram direcionados à criação e manutenção de DEAMs e Casas Abrigo, bem como à capacitação dos agentes de segurança. (IPEA, 2007, 2008a, 2009a, b) A partir de 2004, ${ }^{2}$ percebe-se a incorporação de forma mais efetiva da noção de prevenção e de assistência às mulheres, deslocando a ênfase do combate e promovendo uma ampliação conceitual da política, bem como do escopo das ações que passaram a transcender o restrito foco das políticas de segurança pública. Neste contexto, ganha espaço a proposta de construção de redes compostas por todos os serviços

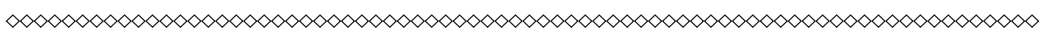

2 Com a criação da Secretaria Especial de Políticas para as Mulheres, da Presidência da República (SPM/PR). 
que atendem as mulheres, cujo objetivo é oferecer-lhes um atendimento integral - e não mais apenas emergencial - que considere todas as dimensões que envolvam o aprimoramento dos mecanismos de prevenção e enfrentamento da violência, como a saúde, a justiça, a segurança pública, a assistência social, o trabalho, a educação e a cultura.

O que se pode perceber, porém, é que, a despeito da ampliação conceitual do escopo das políticas, o aparato estatal da segurança pública - principalmente as DEAMs, as Delegacias de Polícia (DPs) e o serviço de emergência 190, da Polícia Militar - continua a ser porta de entrada privilegiada das mulheres ao universo do Estado em sua busca por proteção e reparação de direitos, seja pela sua maior disponibilidade no espaço nacional, seja pela relação direta que se estabelece entre violência e "polícia”.

Neste contexto, cada vez mais se tem falado sobre a necessidade de se desenhar uma política de segurança pública numa perspectiva feminista, muito embora não se apresente mais elaboradamente o seu desenho. (BIANCARELLI, 2006) Parte-se da identificação de uma nova forma de manifestação de violência que incide sobre as mulheres de forma particular. Para além da violência doméstica e familiar, as mulheres têm também sofrido mais intensamente as consequências da violência urbana e do crime, sobretudo nas áreas conflagradas. (ANISTIA INTERNACIONAL, 2008)

Uma recente e importante fonte de informações a esse respeito é a Central de Atendimento à Mulher - Ligue 180, criada pelo Governo Federal em 2005, com o objetivo de atender e orientar as mulheres em situação de violência. Além de ser uma fundamental porta de entrada para a rede de serviços ofertados pelo Estado, a Central tem produzido um relevante banco de dados com informações para o estudo e análise do fenômeno da violência contra as mulheres no Brasil e, assim, subsidiar o aprimoramento e formulação das políticas públicas na área. 
Muito embora as reclamações sejam, na sua maioria, referentes a situações de violência doméstica e familiar, os dados coletados a partir dos atendimentos realizados na Central trazem elementos para se pensar a relação entre instituições de segurança pública e o atendimento às mulheres em situação de violência. Oferecem-se, assim, novos subsídios para fomentar a reflexão sobre uma política de segurança pública numa perspectiva feminista.

Neste texto, nos propomos a empreender uma análise dos dados oriundos da Central de Atendimento no que se refere às reclamações registradas acerca dos serviços de segurança pública no atendimento a mulheres em situação de violência doméstica e familiar. ${ }^{3} \mathrm{O}$ objetivo é, portanto, identificar as principais falhas, abusos e situações de despreparo enfrentadas pelas mulheres na busca por apoio do Estado, em particular naqueles serviços que aparecem de forma mais recorrente nos registros e, por coincidência, aqueles de maior importância nas situações de violência enfrentadas, como o são as delegacias de polícias, especializadas ou não, e o serviço de emergência da Policia Militar.

Para dar conta dessas questões, este texto é composto por quatro seções além desta introdução. Logo em seguida, são apresentadas algumas considerações metodológicas sobre esta análise, seguidas de um breve histórico descritivo da Central de Atendimento à Mulher. Na seção seguinte, será apresentado o retrato das reclamações recebidas a partir dos dados quantitativos e, logo após, a análise dos relatos das reclamações. Por fim, são apresentadas considerações finais que apontam para as novas questões encontradas sobre a relação entre políticas de segurança pública e violência contra as mulheres.

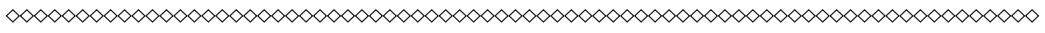

3 A Central recebe reclamações não relacionadas a situações de violência doméstica e familiar, porém em quantidade bastante restrita. Para este estudo, optou-se por trabalhar somente o foco da violência doméstica e familiar, por ser este o objeto da Lei Maria da Penha. 


\section{Sobre esta análise}

Esta análise se inscreve no marco teórico da epistemologia feminista, que nas últimas décadas vem se consolidando como uma importante vertente crítica da produção de conhecimento nas Ciências Sociais em geral. Tal crítica tem sido especialmente produtiva, sobretudo no questionamento das categorias de análise e dos modelos explicativos tradicionais. Ou seja, tem apontado os "pontos cegos" do pensamento social, tais como "a construção do objeto da Sociologia e da constituição do sujeito do conhecimento sociológico.” (MARIANO, 2008, p. 9)

Nesta viragem crítica, se coloca em suspeição a pretensa neutralidade e objetividade da Ciência, demonstrando-se que o sujeito do conhecimento, tido como abstrato e não marcado, corresponde ao modelo masculino da humanidade. Em substituição a essa "objetividade masculinista" (HARAWAY, 1995), opta-se por uma "objetividade feminista e corporificada", assentada no posicionamento dos saberes e dos sujeitos produtores de conhecimento, tal como propõe Donna Haraway (1995). Para essa autora, todo conhecimento é político, parcial e responsável, porque, em função da explicitação do seu posicionamento, é capaz de responder pelas condições da sua produção por meio de uma constante vigilância crítica sobre elas.

Partindo-se dessas premissas, cabe situar as condições de produção desta análise. Ela guarda um duplo objetivo na sua origem: por um lado, pretende-se uma análise técnica crítica da própria Central, com vistas a subsidiar melhorias na oferta do serviço e no seu desenho - deste primeiro objetivo, resultou um pequeno relatório técnico voltado à gestão da política pública. Por outro lado, também almeja-se produzir conhecimento sobre o fenômeno contemporâneo da violação dos direitos das mulheres no país. 
Para tanto, dividimos a análise em duas etapas: i) quantitativa: com informações sociodemográficas de quem liga e dados específicos sobre a demanda; e ii) qualitativa: a partir dos registros produzidos pelas atendentes da Central, com base no que escutam durante $o$ atendimento realizado. Tratam-se, portanto, de relatos de segunda ordem. Sendo assim, conta-se com diferentes filtros subjetivos, os quais, contudo, não impõem grandes limitações à análise.

Todos os relatos das reclamações registradas ao longo de 2008 foram lidos, analisados e reagrupados. Como o "Ligue 180" é um serviço relativamente novo, há, ainda, algumas arestas no seu desenho que análises como esta contribuem para identificar e sugerir modificações. Nos dados sobre as reclamações, mais especificamente, encontramos certa imprecisão nas categorias utilizadas para a sua classificação, o que permite grande margem de discricionariedade e subjetividade na categorização efetuada pelas atendentes do serviço a cada atendimento realizado, possibilitando distintas interpretações de fenômenos idênticos e, assim, distorções nas análises estatísticas. Para fins deste estudo, portanto, construímos outras categorias analíticas a partir das recorrências apresentadas nos registros, reveladoras da relação entre as demandantes e os agentes dos serviços de segurança pública.

\section{A Central de Atendimento à Mulher}

A Central de Atendimento à Mulher - Ligue 180 é uma central de atendimento telefônico da Secretaria Especial de Políticas para as Mulheres (SPM), que tem por objetivo receber denúncias/ relatos de violência e reclamações sobre os serviços da rede, além de orientar as mulheres sobre seus direitos, encaminhando-as para os serviços da Rede de Atendimento à Mulher em Situação 
de Violência ${ }^{4}$ quando necessário. A Central funciona por meio do número 180, caracterizado como número de utilidade pública, podendo ser acessado gratuitamente de qualquer terminal telefônico (móvel ou fixo, particular ou público) todos os dias da semana, inclusive domingos e feriados, em qualquer horário. ${ }^{5}$

O número 180 surgiu a partir de uma demanda da Lei n. 10.714, de 13 de agosto de 2003, que autoriza o Poder Executivo a disponibilizar, em âmbito nacional, número telefônico destinado a atender denúncias de violência contra a mulher. (BRASIL, 2003) De acordo com a lei, seria de responsabilidade das Delegacias Especializadas de Atendimento à Mulher o atendimento às ligações, devendo o número ser composto por três dígitos e de acesso gratuito. Por meio de ato específico, a Agência Nacional de Telecomunicações (Anatel) atribuiu o número 180 para o atendimento descrito na legislação referida, caracterizando esse como serviço de utilidade pública de emergência. Em novembro de 2005, a SPM centralizou o atendimento e constituiu a Central de Atendimento à Mulher.

Por conta do disposto nas legislações específicas, as listas de números de utilidade de emergência, bem como as teclas de emergência disponíveis nos telefones públicos, trazem o número 180 como número de acesso às Delegacias Especializadas e, por isso, grande parte das ligações que chegam na Central vem em busca de supostos atendimentos pelas DEAMs.

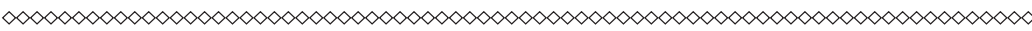

40 conceito de Rede de Atendimento refere-se à atuação articulada entre as instituições/ serviços governamentais, não governamentais e a comunidade, visando à ampliação e melhoria da qualidade do atendimento, à identificação e ao encaminhamento adequado das mulheres em situação de violência, e ao desenvolvimento de estratégias efetivas de prevenção. Integram a Rede não apenas os serviços especializados de atendimento às mulheres (casas-abrigo, centros de referência, DEAMs, Juizados Especiais, etc.), mas também os serviços não especializados que as atendem, como as delegacias comuns da polícia civil, os serviços de saúde, o número 190 da Polícia Militar, entre outros.

5 Todas as atendentes trabalham a partir de um sistema informatizado composto por: i) um módulo de informações permanentemente atualizado sobre tipos de violência contra as mulheres, sobre a Lei Maria da Penha e outras legislações relacionadas à garantia aos direitos da mulher e sobre a SPM; ii) um módulo com endereços e telefones de serviços que compõem a rede de atenção à mulher; e iii) um módulo de registros que permite a classificação dos relatos de violência e das reclamações sobre os serviços da rede. 
A Central começou a funcionar, em caráter experimental, em novembro de 2005, de segunda a sexta-feira, apenas em horário comercial, a partir de um acordo de cooperação técnica entre a SPM e o Ministério da Saúde, que viabilizou a infraestrutura, os recursos tecnológicos e humanos até abril de 2006. A partir de então, a Central passou a funcionar em instalações próprias, com nova infraestrutura e maiores recursos. O horário de atendimento foi expandido, o serviço passou a funcionar 24 horas por dia, ininterruptamente, e o número de posições de atendimento aumentou de quatro para $20 .^{6}$

Desde a sua criação, a Central tem apresentado um aumento significativo no volume de ligações recebidas e de atendimentos efetuados. Entre 2005 e 2008, houve um crescimento de mais de $1.700 \%$ no total de atendimentos realizados, que passou de quase 15 mil, no primeiro ano de funcionamento do serviço, para cerca de 271 mil, em 2008. Essa evolução, aparentemente, deve-se não só às melhorias metodológicas e tecnológicas implementadas ao longo dos três primeiros anos de funcionamento da Central, mas também à sanção da Lei Maria da Penha e à divulgação do serviço. ${ }^{7}$

A Central coleta dados cadastrais das mulheres que procuram o serviço (faixa etária, escolaridade, estado civil, cor/raça, entre outros), bem como registra detalhada e padronizadamente todos os atendimentos prestados. Os atendimentos podem ser classificados como: i) informação: é o repasse de informações técnicas relacionadas à temática do serviço e que são respondidas com base na consulta ao banco de dados; ii) denúncia/relato de violência:

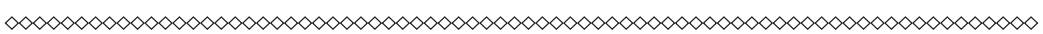

6 Posições de Atendimento (PA) são as cabines disponíveis para as atendentes desenvolverem suas atividades. 0 número de PAs corresponde à capacidade de atendimento do serviço.

7 Considerando que a atual capacidade instalada não suporta o crescimento da demanda apresentado no último ano, será dobrado o número de postos de atendimento e implementados novos mecanismos tecnológicos que facilitarão o fluxo e acompanhamento das demandas recebidas na Central junto aos órgãos/instituições de competência nos estados e municípios, em especial a Ouvidoria da SPM, o Ministério Público, as corregedorias de polícia, os organismos governamentais de políticas para as mulheres e os conselhos de direitos. 
é todo registro de informações relacionadas aos atos de violência relatados pelas pessoas que procuram a Central; iii) reclamação: é o registro de críticas ao funcionamento inadequado dos serviços que compõem a rede de atendimento às mulheres; iv) elogio: é o registro da manifestação de satisfação das (os) usuárias (os) referente aos serviços que compõem a rede em todo o país; v) sugestão: é o registro das propostas recebidas de melhoria ou de ações no âmbito do combate à violência contra as mulheres; e vi) serviços: é o encaminhamento das (os) usuárias (os) aos serviços que compõem a rede de atenção às mulheres.

Outra peculiaridade que deve ser ressaltada diz respeito à metodologia de encaminhamento dos registros de reclamações recebidas. A cada atendimento realizado pela Central, em especial a cada encaminhamento para serviços da Rede, as atendentes orientam as mulheres para que, em caso de não receberem o atendimento adequado nos serviços procurados - sejam eles especializados ou não -, procurem novamente a Central, informando o tipo de dificuldade encontrada. Ainda não é possível identificar quantos dos registros de reclamação recebidos são decorrentes de encaminhamentos realizados pelo Ligue 180, mas estimamos, com base na leitura dos relatos, que a maioria das reclamantes são usuárias reincidentes da Central. Importante destacar, ainda, que todos os registros de reclamação são encaminhados à Ouvidoria da SPM, que recebe os registros realizados no atendimento e encaminha e/ou apura de acordo com o caso.

Especificamente em relação ao mau atendimento recebido nos serviços da Rede, foi realizado, em julho de 2008, um trabalho de capacitação/sensibilização junto às atendentes da Central para melhor percepção dos relatos de reclamações no discurso das usuárias do serviço. Isso porque muitas vezes as reclamações não correspondem à principal demanda das mulheres que procuram o serviço, mas é importante que a atendente perceba e informe a 
recorrência destas situações. Com isso, houve um aumento significativo no número de registros de reclamações, que passaram de uma média mensal de 76 atendimentos, entre janeiro e junho de 2008, para 250, entre julho e agosto, um aumento de $227 \%$ na média mensal.

$\mathrm{O}$ aumento no número de registros de reclamações também evidenciou a necessidade de rever as classificações adotadas e a necessidade de um trabalho, junto às atendentes, acerca da organização, das atribuições e competências de cada um dos serviços que compõem o aparato da segurança pública.

\section{Retrato das reclamações recebidas}

A criação da Central de Atendimento à Mulher, em 2005, representou a instauração de um novo elo da Rede de Atendimento às Mulheres em Situação de Violência, ao lado de serviços como casas-abrigo, centros de referência e delegacias de polícia. No entanto, além de ser um serviço ofertado às mulheres, a Central funciona como uma porta de entrada para outros serviços integrantes da Rede, realizando encaminhamentos e fornecendo orientações, e também como um instrumento que monitora a atuação de cada uma dessas instituições do Estado. Cabe ao Ligue 180, portanto, ouvir a sociedade a respeito do atendimento recebido em cada serviço que integra a Rede e, a partir desse acompanhamento junto às/aos usuárias/os, estabelecer um fluxo para que as eventuais reclamações alcancem os órgãos competentes e possam ser, se não solucionadas, ao menos discutidas no âmbito de cada instituição com o intuito de aprimorar os atendimentos prestados.

É a partir desse eixo de ação da Central, como um mecanismo de monitoramento e avaliação da Rede, que se desenvolve a análise sobre as reclamações recebidas no Ligue 180. É importante contextualizar, antes, o tamanho da rede de serviços de enfrentamen- 
to da violência contra as mulheres disponível hoje no país, pois é essa a estrutura do Estado ofertada às mulheres na realidade local e sobre a qual se constroem as queixas que aqui serão relatadas.

Desde 2004, com as modificações no escopo da política de enfrentamento à violência contra as mulheres, o número de serviços, bem como a natureza dos mesmos, vem se ampliando significativamente. Atualmente, estão à disposição da sociedade 681 serviços especializados de atendimento às mulheres em situação de violência, dentre os quais: 418 delegacias ou postos especializados; 132 centros de referência; 68 casas-abrigo; e 63 juizados ou varas especiais de violência doméstica e familiar. ${ }^{8}$ Ainda que tenha crescido substancialmente ao longo dos anos, a Rede hoje existente ainda é limitada para responder a todas as demandas existentes, tanto em termos de quantidade de serviços disponíveis, quanto em relação à sua concentração territorial (ver Tabela 1 do Anexo). Para além dos serviços especializados, outros serviços, mesmo que não específicos, atendem um grande número de mulheres em situação de violência, a exemplo das delegacias comuns da polícia civil, ${ }^{9}$ do número emergencial da polícia militar (190), das defensorias públicas etc. É sobre esse conjunto de instituições, especializadas ou não, que as reclamações recebidas pela Central discorrem.

Em 2008, a Central realizou cerca de 271 mil atendimentos, número quase $33 \%$ superior ao verificado para o ano de 2007 (ver Tabela 2 do Anexo). Isso não significa, porém, que foram atendidas 271 mil mulheres, pois uma única ligação pode conter uma ou mais demandas. A maioria dos atendimentos realizados no ano consistiu no encaminhamento de mulheres em situação de violência para os serviços da Rede $(37,7 \%)$ e na prestação de in-

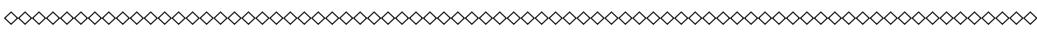

8 Criados a partir da Lei Maria da Penha.

9 Em 2006, havia no país pouco mais de 5 mil Unidades Operacionais da Polícia Civil (não especializadas), segundo dados do Ministério da Justiça. 
formações $(52 \%) .{ }^{10}$ As denúncias ou relatos de violência responderam por cerca de $9 \%$ e as reclamações por menos de $1 \%$ do total de atendimentos realizados. Esses percentuais confirmam que, mais do que captar denúncias ou acompanhar o desempenho dos serviços, o foco da Central é orientar e oferecer ajuda às mulheres em situação de violência, motivo pelo qual foi criada em 2005.

\section{Perfil das/os reclamantes}

Comparativamente aos outros atendimentos prestados pela Central, portanto, são poucas as mulheres (ou homens) que procuram o Ligue 180 para realizar reclamações sobre instituições da Rede de Atendimento às Mulheres em Situação de Violência. Ainda que seja um público mais restrito, o perfil das/os reclamantes em nada difere daquele identificado para as demais pessoas que procuram a Central para outro tipo de atendimento, ou seja, não é possível identificar, pelos dados disponíveis, características específicas para aqueles/as que optam por denunciar um mau atendimento recebido nos serviços ofertados pelo Estado.

Faz-se necessário ressaltar um importante aspecto metodológico que se refere à alta taxa de não resposta à demanda por informações, como estado civil, idade, entre outras. Se, por um lado, esse fato está diretamente relacionado à juventude do serviço e à permanente necessidade de se trabalhar junto às atendentes para que se possa coletar os dados da melhor maneira possível, por outro, não há como desconsiderar a natureza do fenômeno da violência contra as mulheres que envolve sentimentos como ver-

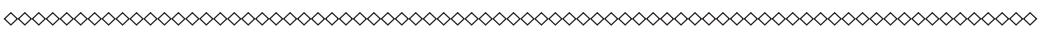

10 Dois movimentos importantes merecem ser mencionados entre os anos de 2007 e 2008: a) o aumento expressivo na quantidade de informações fornecidas pela Central, em função basicamente de uma maior divulgação do serviço e da Lei Maria da Penha, tema mais demandado pelas mulheres/homens que procuram o serviço; e b) redução de 20 pontos percentuais no encaminhamento de mulheres para serviços: neste caso, a maior e melhor capacitação das operadoras para o atendimento produziu um resultado, que foi a redução do encaminhamento para diversos serviços na cidade da demandante e um maior foco com o encaminhamento apenas para o serviço mais adequado. 
gonha e medo e que, portanto, pode desestimular a identificação daquelas em situação de violência. Optou-se, aqui, por apresentar as distribuições da população pelas diversas categorias descontando-se a taxa de não informados. Os dados completos, porém, estão disponíveis nas tabelas dispostas no anexo deste texto.

Inicialmente, pode-se perceber que são de fato as mulheres as que mais reclamam do atendimento recebido nos serviços, sejam elas as próprias "vítimas" da situação de violência, sejam elas amigas ou familiares que constroem um círculo de solidariedade e denunciam comportamentos entendidos como não aceitáveis para agentes públicos (ver Quadro 1 no Anexo).

A grande maioria das mulheres reclamantes encontra-se na faixa de 20 a 40 anos de idade ( $67 \%$ delas) e são casadas ou estão em uniões estáveis $(59,8 \%)$. Há, no entanto, uma sobrerrepresentação desses grupos de mulheres, uma vez que aquelas de 20 a 40 anos de idade representam apenas $32 \%$ da população feminina brasileira ${ }^{11}$ e as casadas ou em união estável não somam mais do que $36 \%$ das mulheres do país. ${ }^{12}$ Nessa faixa etária, as mulheres já se encontram sexualmente ativas e no auge da sua fase reprodutiva, sendo comum a recorrência de casamentos e recasamentos, seguidos de conflitos conjugais, o que amplia a probabilidade de que enfrentem situações de violência e, consequentemente, de que procurem os serviços ofertados pelas instituições públicas e venham a fazer reclamações quanto ao atendimento ali recebido. Ademais, esse dado

[...] também permite levantar a hipótese de que, por se tratar de uma geração que vive numa conjuntura histórica em que a luta contra a violência é pervasiva a toda a sociedade, essas mulheres se sentem legitimadas a denunciar as relações violentas em que

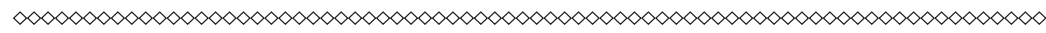

11 Segundo dados da Pesquisa Nacional por Amostra de Domicílios de 2007 (PNAD) do Instituto Brasileiro de Geografia e Estatística (IBGE, 2007).

12 Segundo dados do Censo Demográfico de 2000 do IBGE. 
se encontram, procurando ajuda. (BONETTI; PINHEIRO; FERREIRA, 2008, p. 5)

No caso dos dados relativos à escolaridade, a Central coleta informações sobre o último nível de ensino que a pessoa cursou ou está cursando. Quase $90 \%$ das mulheres que efetuam reclamações junto ao Ligue 180 possuíam até nível médio completo, sendo que a proporção de analfabetas entre as que procuram o serviço é insignificante $(0,9 \%)$, tanto na comparação com aquelas que são alfabetizadas, quanto com a distribuição da população feminina no país (10\% das mulheres brasileiras eram analfabetas, em 2007). Levanta-se a hipótese, portanto, de que o serviço telefônico não chega àquelas mulheres que não têm inserção na cultura das letras, sendo um serviço mais acessível às mulheres educadas, e que estas tendem a reclamar com menor frequência dos serviços do Estado.

Já em relação às informações sobre raça/cor, importa considerar que esse é o quesito que apresenta maior taxa de não resposta (quase $17 \%$ ), o que evidencia as dificuldades ainda existentes - e recorrentes nos mais diversos registros administrativos ou pesquisas domiciliares - na construção e afirmação de uma identidade que foi, durante séculos, escamoteada pelo mito da democracia racial e da miscigenação cordial. Assim, há que se considerar uma prevalência maior das populações preta e parda na distribuição dos atendimentos do Ligue 180 quando comparadas à distribuição da população feminina no país: $56,6 \%$ das reclamantes que informaram sua cor/raça eram negras, enquanto esse percentual é de inferiores $48 \%$ para as mulheres brasileiras. Em sentido oposto, $41 \%$ das atendidas pela Central eram brancas, frente a uma população feminina total que concentra 50,6\% de mulheres nessa condição de raça/cor. Como principal hipótese para explicar tal discrepância, recorre-se ao conceito de racismo institucional, entendido como aquele que 
[...] não se expressa por atos manifestos, explícitos ou declarados de discriminação orientados por motivos raciais. Ao contrário, o racismo institucional atua de forma difusa no funcionamento cotidiano de instituições e organizações, que passam a operar de forma diferenciada na distribuição de serviços, benefícios e oportunidades a diferentes grupos raciais. (IPEA, 2007, p. 10)

Muitos são os relatos de mulheres violentadas pelas instituições do Estado, especialmente em função da reprodução de estereótipos e preconceitos que banalizam a violência doméstica e familiar. A essas situações, soma-se o racismo institucional, que torna ainda mais difícil para as mulheres negras o acesso qualificado aos serviços e, consequentemente, o rompimento do ciclo da violência.

Finalmente, no tocante à distribuição regional dessa população, os dados apontam que $56 \%$ das reclamantes residem em unidades da federação da região Sudeste. Há, novamente, uma sobrerrepresentação das mulheres dessa região na comparação com a distribuição da população feminina no Brasil de modo geral, que chega somente a $41 \%$. Nesse caso, a explicação encontra-se tanto na maior densidade populacional desses estados, quanto na maior oferta de serviços, especialmente no estado de São Paulo, que, junto ao Rio de Janeiro e Minas Gerais, concentra 44\% dos serviços especializados disponíveis no país.

\section{Perfil das reclamações}

Durante todo o ano de 2008, foram recebidas 1.959 reclamações sobre os serviços especializados ou não de atendimento às mulheres, o que equivale a apenas $0,7 \%$ do total de atendimentos efetuados pela Central. Isso não significa, obviamente, que não haja um número maior de críticas e denúncias a respeito dos atendimentos recebidos, ou que o conjunto de serviços que atende às mulheres em situação de violência esteja funcionando da maneira 
mais adequada, segundo as normas técnicas produzidas pela SPM e pela Secretaria Nacional de Segurança Pública, do Ministério da Justiça. De fato, há que se destacar a prevalência de uma cultura que não associa o bom atendimento nos equipamentos públicos a uma questão de acesso a direitos e, portanto, não estimula a denúncia e a reclamação aos órgãos competentes. Há, muitas vezes, uma noção de que o agente público, ao efetuar um bom atendimento, está "prestando um favor" à mulher e não garantindo o seu direito a um serviço de qualidade e eficiência. Configura-se, assim, um quadro de violência que se soma à agressão doméstica e familiar (ou pública) e àquela praticada pelo Estado e que pode ser denominada violência institucional.

Ademais, as condições de fragilidade e instabilidade vivenciadas pelas mulheres não evidenciam o mau atendimento como a questão mais importante a ser resolvida no momento. Quando se analisam os relatos registrados nos mais diversos tipos de denúncias de violência recebidas na Central (como tentativa de homicídio, agressão física ou cárcere privado, por exemplo), é bastante recorrente a narrativa de que essas mulheres já procuraram os serviços existentes na cidade, em especial DEAMs ou delegacias comuns, e de que foram mal atendidas. A reclamação nem sempre se constitui em objeto da ligação ao Ligue 180, podendo não ser assim percebida pela mulher que procura a Central ou pela operadora que a atendeu.

No entanto, é importante destacar o expressivo aumento na quantidade de reclamações recebidas no serviço, que passou de 904 para 1.959 entre 2007 e 2008, um crescimento de $116 \%$ (ver Tabela 2 do anexo). Não há um único fator para explicar esse fenômeno, mas certamente, entre as causas, é possível destacar: i) a ampliação da Rede Especializada de Atendimento: incremento de $12 \%$ no período na oferta de serviços; ii) maior divulgação 
e conhecimento da Central; e iii) capacitação das atendentes da Central sobre o tema de reclamações.

Ainda que os números sejam de pequena monta, importantes aspectos podem ser apreendidos da análise das informações produzidas, especialmente dos relatos, tal como se verá na seção seguinte. Inicialmente, cabe destacar que os serviços que mais apresentam registros de reclamação na Central são as Delegacias de Polícia, especializadas ou não no atendimento à mulher, seguidas do número 190, de atendimento telefônico da polícia militar: juntos, respondem por quase $90 \%$ do total de reclamações registradas (ver Tabela 3 do Anexo). ${ }^{13}$

Segundo a Constituição Federal (CF), às polícias militares cabem a polícia ostensiva e a preservação da ordem pública, estando subordinadas aos governadores dos estados e do Distrito Federal. O número 190 é o número de utilidade pública de emergência da polícia militar, devendo ser acionado para casos de delitos que necessitem de atendimento de urgência, incluindo aqueles relacionados à violência doméstica e familiar contra as mulheres. (BRASIL, 1988)

A CF, em seu artigo $144, \S 4^{\circ}$, determina que às polícias civis, dirigidas por delegados de polícia de carreira, incumbem as funções de polícia judiciária e a apuração de infrações penais. Esses serviços - especializados ou não - devem estar preparados para o atendimento de mulheres que vivenciem qualquer tipo de violência. Em caso de violência doméstica e familiar, a Lei n. 11.340/06 (Lei Maria da Penha) dispõe sobre os procedimentos a serem adotados pela autoridade policial. (BRASIL, 1988, 2006)

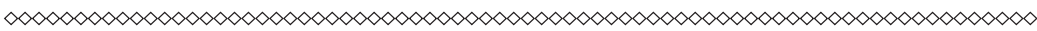

13 Em 2007, esse percentual alcançava "apenas" 70\%, não porque os serviços de segurança eram menos reclamados, mas porque grande parte das reclamações sobre essas instituições estava agregada na categoria "outros", que somou $26 \%$ do total de reclamações daquele ano, em função de mudanças na base de dados que impossibilitaram a identificação dos serviços-alvo das reclamações entre janeiro e abril de 2007. 
O grande foco das reclamações encontra-se, portanto, no aparato da segurança pública, espaço mais procurado pelas mulheres quando é tomada a decisão, ainda que impulsiva ou temporária, de denúncia e de rompimento do ciclo da violência. Por serem em grande parte dos casos as portas de entrada ao aparato estatal, amplia-se a importância de um bom atendimento, acolhedor e humanizado, e da prestação de um serviço de qualidade, em obediência ao disposto nas leis e normas vigentes. É exatamente em cima desses dois pontos que se concentram as reclamações recebidas pela Central em relação às DEAMs, às delegacias comuns da polícia civil e ao número 190 da Polícia Militar. De modo geral, as queixas estão relacionadas: i) ao despreparo e à falta de comprometimento na aplicação da legislação vigente; e ii) ao atendimento inadequado em função de comportamentos que reproduzem estereótipos e preconceitos no atendimento. Os dados apontam, assim, para a necessidade contínua de capacitação e qualificação dos profissionais e de divulgação da nova lei de forma ainda mais intensa.

\section{Relatos sobre as reclamações}

Cada uma das reclamações recebidas na Central é classificada tanto em relação ao serviço ao qual se refere, quanto em relação ao seu conteúdo. Nesse caso, os relatos são classificados em diferentes categorias, tais como: omissão, despreparo, atendimento inadequado, dificuldade de acesso, falta de providência sobre o boletim de ocorrência, recusa em registrar o boletim de ocorrência, entre outras. Na análise dos registros, porém, foi possível perceber que as classificações sobre as quais se agrupam os registros hoje na Central guardam certa imprecisão, conforme já relatado. Assim, optamos por não trabalhar as informações quantitativas sobre o conteúdo das reclamações armazenadas no banco de dados, mas 
apenas os registros qualitativos informados pelas atendentes e que permitem conhecer de forma mais fidedigna esse conteúdo.

Para este estudo, criamos, então, outra forma de organização dos relatos, a partir de três grandes grupos de reclamações, comuns aos três serviços em análise. Tais reclamações aparecem tanto em casos de atendimento efetivado quanto naqueles em que houve recusa de atendimento às reclamantes pelos agentes de segurança pública.

\section{Problemas infraestruturais}

Neste grupo, enquadram-se as reclamações que denunciam a precariedade dos serviços oferecidos relativas à ausência de infraestrutura adequada para o seu pleno funcionamento. Dentre elas, encontram-se: a falta de viatura, telefone sem resposta, demanda fora da jurisdição do serviço, delegacias fechadas e falta de recursos humanos.

Na sequência, citamos partes de alguns desses relatos que evidenciam a precariedade no diz respeito à infraestrutura:

1. Cidadã relata que ligou para o 190 solicitando uma viatura no local. Os agentes policiais disseram que não poderiam fazer absolutamente nada, pois não tinha viatura. Além de informar que não podem fazer nada, pois não é de sua competência.

2. Cidadã reclama do 190 por não ter comparecido no local solicitado numa situação de emergência (violência doméstica e familiar) após ter ligado por três vezes. A atendente informou que talvez não comparecessem devido a muitos chamados urgente na sua frente.

3. Cidadão relata que compareceu à delegacia comum para pedir socorro para sua vizinha que é mantida em cárcere 
privado. Foi atendido por um agente que falou que não era da competência daquela delegacia e que se eles não estavam dando conta dos problemas da sua jurisdição, imagine da outra jurisdição.

4. Cidadã reclama que esteve na delegacia de mulher e a atendente se recusou a fazer o boletim de ocorrência, alegando que o sistema estava fora do ar. A atendente pediu para a cidadã retornar no dia seguinte porque a DEAM fechava às 19 h e só havia um escrivão atendendo.

5. Cidadã foi à delegacia comum e foi atendida por um guarda que disse que as delegacias estavam em greve e ela não poderia registrar o boletim de ocorrência.

6. Cidadã compareceu à delegacia comum para registrar um boletim de ocorrência por ter sofrido violência, porém a pessoa que estava na recepção informou que naquela delegacia não fazia boletim de ocorrência no período da manhã, somente à tarde.

7. Cidadã relata que foi à DEAM para registrar um BO. Depois de registrada a denúncia, a delegada a encaminhou para fazer o exame de corpo delito e informou à vítima que não tinha nenhuma viatura e, se ela quisesse, que arrumasse carona ou desse algum jeito, pois precisava do exame ainda hoje.

8. Cidadã reclama que na DEAM não tem nenhuma delegada. Há um delegado titular da $99^{\mathrm{a}}$ DP que está respondendo pela DEAM nos expedientes, mas as moradoras da cidade querem uma delegada na DEAM. As cidadãs se sentem constrangidas em falar com um homem na delegacia.

9. Cidadã está revoltada com as propagandas enganosas que vê ou escuta na televisão. Precisou do atendimento na DEAM e quando chegou ao local estava fechada. Infelizmente, não 
pode contar com o atendimento da DEAM, até porque não funciona nos finais de semana e feriados, que são os dias que as mulheres mais precisam.

10. Cidadã Renata, 28 anos, relata que na cidade de Quajaru/BA não tem delegado durante a semana. Só uma vez por semana (na segunda feira) que a delegada vem da cidade vizinha para realizar atendimento.

Reunidos pelo elo comum dos problemas infraestruturais como entraves para o pleno funcionamento dos serviços de segurança pública, os relatos deste grupo nos apontam mais diretamente para a ausência e falha do Estado no cumprimento do seu dever constitucional de garantidor da segurança de todos e todas. Além da falta material objetiva, tais como a falta de viaturas disponíveis ou mesmo situações de falta de recursos humanos, observa-se também que, em se tratando de demandas relativas ao tema da violência doméstica e familiar, parece haver, subliminarmente, um consenso tácito sobre a gravidade menor desse tipo de crime, que se revela no entendimento de haver outros casos mais urgentes a serem tratados, pouca disponibilidade para o atendimento desses casos, como na situação da delegacia de polícia comum, que só registra tais ocorrências no período da tarde. Esses elementos, que figuram nessas situações como pano de fundo dos não menos graves problemas infraestruturais, revelam valores de uma visão de mundo própria do universo da segurança pública, que não entende a violência contra as mulheres, na sua faceta doméstica/familiar, como um crime.

\section{Despreparo dos agentes de segurança pública}

Sob esta categoria foram reunidas aquelas reclamações que versam sobre os procedimentos equivocados adotados pelos agentes de segurança, em especial no tratamento de demandas 
de violência doméstica e familiar. Deparamo-nos com relatos de tentativas de mediação/conciliação em situações de violência, o entendimento de que o serviço não tem competência ou não está habilitado para tratar do tema da violência doméstica e familiar, desconhecimento dos procedimentos da Lei n. 11.340/06, demanda de autorização para prisões em flagrante, entre outros. Nos relatos aqui reunidos, a noção de que violência doméstica e familiar não é um crime, ou, no melhor dos casos, um crime menor, vai se tornando mais evidente.

Uma das características marcantes desses relatos é o discurso do "conflito de competências", por meio do qual as mulheres deixam de receber atendimento em função de um entendimento equivocado por parte dos agentes dos serviços, que têm lidar com casos de violência doméstica e familiar, não se configurando em sua competência institucional. É possível perceber que parte desse discurso se dá mesmo em função do despreparo das agentes que acreditam não ser de sua responsabilidade esses temas. No entanto, um outro conjunto de relatos reflete mais o uso do conflito de competências como uma "desculpa" para que os serviços possam não atuar em casos considerados não importantes. Espanta, ainda, o fato de terem sido identificados registros de agentes de DEAMs justificando o não atendimento pela falta de competência das delegacias especializadas para lidar com esses casos. Seguem alguns relatos:

1. Cidadã relata que na delegacia de polícia foi informada que, em casos de violência doméstica, o BO só pode ser registrado em uma DEAM, para que a vítima tenha direito à Lei Maria da Penha.

2. Senhora esteve na DEAM para fazer o BO contra o companheiro que a agride com frequência, e os policiais se negaram a registrá-lo dizendo que $\mathrm{BO}$ relacionado à violência 
domestica e familiar não era com eles, sendo ela orientada a procurar a delegacia civil.

3. Cidadã informa que procurou a DEAM e foi mal atendida pelo funcionário, que informou que lá não era o lugar adequado e que ela deveria procurar uma DP próxima a sua residência.

4. Cidadã relata que sofre violência física por parte do marido e não consegue atendimento pelo 190 no momento da agressão. A cidadã foi orientada a entrar em contato com o Ligue 180, que é a central que trata sobre a violência doméstica e familiar.

5. Cidadã compareceu à $50^{\mathrm{a}}$ delegacia de polícia para registrar um BO por ter sofrido violência doméstica e familiar, e o delegado que a atendeu recusou-se a fazê-lo, alegando que tinha muita coisa para resolver e que a mesma procurasse a DEAM.

No campo do não atendimento por despreparo, cabe chamar a atenção para dois padrões verificados. O primeiro deles refere-se à falta de conhecimento dos procedimentos introduzidos pela Lei Maria da Penha (n. 11.340/2006), que inova no que diz respeito à descrição dos procedimentos a serem adotados pela autoridade policial em casos de violência doméstica e familiar contra a mulher. De fato, as autoridades policiais passaram, com a Lei Maria da Penha, a contar com uma série de novos procedimentos para os casos de violência doméstica e familiar contra as mulheres, em especial: i) a permissão da autoridade policial para prender o agressor em flagrante sempre que houver qualquer forma de violência doméstica contra a mulher; ii) o registro do boletim de ocorrência e a instauração do inquérito policial (composto pelos depoimentos da vítima, do agressor, das testemunhas (se houver) e de provas documentais e periciais); iii) a necessidade de remeter 
o inquérito policial ao Ministério Público; iv) a possibilidade de requerer ao juiz, em $48 \mathrm{~h}$, que sejam concedidas diversas medidas protetivas de urgência para a mulheres em situação de violência; e v) a solicitação ao juiz da decretação da prisão preventiva com base na nova lei que altera o código de processo penal.

A aplicação incorreta da Lei não é de todo surpreendente por se tratar de uma norma com relativo pouco tempo de vigência, que altera substancialmente o cotidiano de trabalho das delegacias, provocando, assim, resistência à sua adequada e completa aplicação. (BONETTI; PINHEIRO, 2007) No entanto, é preocupante a quantidade de relatos de despreparo sobre os/as agentes de delegacias especializadas, que, em função da natureza dos serviços e dos investimentos públicos, deveriam estar bem mais preparados para lidar com as novidades introduzidas pela nova legislação do que o verificado na prática. Alguns relatos exemplificam essa situação.

1. Cidadã ligou no 190 e o policial que a atendeu relatou que não poderia ir até o local, pois não tinha ordem judicial para levar o agressor preso em flagrante;

2. Cidadã compareceu à DP para registrar um boletim de ocorrência. No atendimento, o boletim de ocorrência não foi registrado porque foi informada de que precisaria de, no mínimo, duas testemunhas;

3. A escrivã afirmou que não seria registrado o BO nos termos da Lei n. 11.340, porque ela não mora mais junto com ele e essa lei só atende quem mora junto. No dia seguinte, voltou para refazer a ocorrência, sendo atendida por outra escrivã, que afirmou poder registrar o $\mathrm{BO}$ nos termos da Lei n. 11.340, porém, no fórum da cidade, alguns juízes não aceitam a lei porque ela desfavorece o homem; 
4. Cidadã foi agredida por seu cunhado. A vítima foi atendida pelo 190 e orientada a procurar a DEAM. Quando chegou na delegacia, não conseguiu fazer o boletim de ocorrência, pois foi informada que a Lei n. 11.340 só assiste violência praticada pelo marido;

5. Cidadã compareceu à DEAM e foi informada pela escrivã que eles não têm obrigação de encaminhar as medidas protetivas de urgência ao juiz, pois quem tem a obrigação de encaminhar é a defensoria pública;

6. Cidadã relata que procurou a DEAM para registrar um boletim de ocorrência contra o seu agressor, mas não foi informada da Lei n. 11.340. A cidadã é que disse à delegada que, de acordo com a Lei Maria da Penha, tinha o direito de solicitar as medidas protetivas de urgência contra o agressor, porém a delegada afirmou que a lei citada não apresentava nada de novo e que era igual à lei anterior. A delegada ainda disse que a cidadã teria de se encaminhar ao fórum da cidade para pedir ao juiz a saída do acusado de casa;

7. Cidadã reclama que compareceu à DEAM para registrar BO de violência doméstica e solicitar as medidas protetivas de urgência. Durante o atendimento, a escrivã disse que somente um advogado poderia solicitar tais medidas;

8. Cidadã compareceu na delegacia comum, porém o agente recusou-se a registrar $\mathrm{BO}$,alegando que o esposo da vítima já tinha ido naquela delegacia e feito o boletim de ocorrência e que não podia ter dois boletins pelo mesmo acontecido, e também que a vítima não tinha hematomas e nem ferimentos, mas o agressor tinha;

9. Cidadã sofreu agressão física e solicitou uma viatura no 190. Os policiais compareceram no local e a vítima foi orientada pelo delegado a sair de casa porque ele iria ser solto às $8 \mathrm{~h}$, 
pois não tinha motivo para que ele ficasse preso, e se ela estivesse em casa nesse horário, ele a mataria. Ela só poderia solicitar as medidas de proteção na DEAM.

A segunda recorrência nas reclamações sobre os serviços de segurança pública refere-se ao padrão "quantidade de sangue necessária” para se registrar um boletim de ocorrência. À primeira vista, essa necessidade, um tanto perversa da prova material para justificar o registro de ocorrência, parece-nos estar diretamente associada ao não reconhecimento da violência doméstica e familiar como um crime, ou, no caso, um crime menor, já que não houve derramamento de sangue. O ponto máximo dessa percepção se dá no grupo seguinte, marcado pela recusa dos agentes. Importante ter em consideração que a Lei Maria da Penha define como violência contra as mulheres não apenas a violência física, mas também psicológica, moral, sexual e patrimonial, definindo desde então a não necessidade de marcas físicas aparentes para configuração do crime, como encontramos em um grande número de registros de reclamação.

1. Cidadã relata que, ao tentar registrar $\mathrm{BO}$ contra seu marido na DP, o delegado que a atendeu disse que só poderia ajudá-la se ela estivesse muito machucada e ensanguentada. Caso contrário, ele não poderia fazer nada, e que a mesma teria que procurar uma assistente social antes de realizar a denuncia, porque depois seria tarde demais para desistir;

2. Cidadã procurou a DEAM e foi atendida pela delegada, que disse à ofendida que como o agressor não falou em matá-la, não era motivo para o registro do BO, e encaminhou a agredida para outro local;

3. Cidadã informa que esteve na DEAM, onde solicitou medidas protetivas de urgência, sendo que a escrivã se recusou a dar entrada, alegando que somente eram solicitadas às 
mulheres que apresentavam hematomas, perguntando ainda se a ofendida queria realmente dar entrada no processo contra seu companheiro, pois o processo era demorado e trabalhoso, pedindo que a mesma fosse para casa e refletisse a respeito da sua decisão;

4. Cidadã reclama que ligou para a DEAM para ter informações sobre se poderia fazer um $\mathrm{BO}$ de violência psicológica que estava sofrendo do ex-companheiro. A atendente recusou registrar seu $\mathrm{BO}$, alegando não precisar fazer nenhum registro porque a violência psicológica não é agressão.

5. Cidadã informa que compareceu à $71^{\text {a }}$ delegacia comum e não teve o seu $\mathrm{BO}$ registrado. O escrivão disse que só poderia fazer algo se o companheiro a matasse.

\section{Recusas dos agentes de segurança pública}

Nessa categoria se enquadra toda a sorte de recusas feitas pelos agentes de segurança pública às demandas das reclamantes em casos de não atendimento, ou mesmo de atendimento. Tais recusas estão embasadas num entendimento de que a violência doméstica e familiar não seria um crime, antes uma situação cujo fórum de resolução não seria o aparato do Estado, e menos ainda o da segurança pública.

O conjunto dos relatos analisados permite identificar que, diferentemente da categoria "despreparo", a recusa feita à demanda das reclamantes se dá num contexto explícito e valorativamente carregado de avaliação moral, a qual recai, na esmagadora maioria das vezes, negativamente sobre a mulher em situação de violação de seus direitos. São recorrentes os relatos de dificuldades enfrentadas pelas demandantes quando os agentes de segurança pública suspeitam ou questionam: i) a sua palavra, buscando a prova material da violência; ii) o seu comportamento, indagando o que uma 
mãe de família fazia à noite fora de casa, que não estava a cuidar dos seus filhos, ou afirmando que a mulher apanha porque gosta ou porque provoca, pois, caso contrário, já teria saído de casa. ${ }^{14}$

Verifica-se, nesses casos, a operação de um processo de banalização da violência doméstica e, sobretudo, da conjugal, a partir do qual se percebe a agência de convenções tradicionais de gênero na constituição e reprodução de modelos de feminilidades e masculinidades que informam estereótipos de gênero desqualificadores do feminino e enaltecedores de um tipo específico de masculino, aquele que se significa a partir da virilidade agressiva. Assim, nesse grupo marcado pela recusa, explicita-se um nível máximo da negação da violência doméstica e conjugal como um crime digno de ser investigado. Essa banalização é a responsável pela incidência de homicídios que poderiam ser evitados, como um dos casos encontrados dentre os relatos de recusas.

1. A cidadã relata que ligou para o serviço 190 , pois sua vizinha estava sofrendo violência por parte do companheiro. A pessoa que atendeu a ligação recusou o serviço dizendo que em briga de marido e mulher eles não se envolvem;

2. A cidadã relata que aconteceu um homicídio devido ao descaso da delegacia e o não funcionamento da Lei $n$. 11.340/2006. Uma mulher foi à delegacia da cidade fazer uma denúncia da violência física e ameaças de morte que estava sofrendo pelo ex-marido. Mesmo havendo hematomas, o funcionário da DP se negou a formalizar a denúncia e

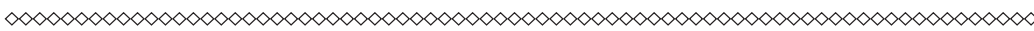

14 É importante destacar que relatos de mesmo conteúdo podem encobrir motivações diferenciadas dos agentes. Assim, a exigência de marcas para registro do Boletim de Ocorrência pode ocorrer em função do despreparo do agente em relação ao arcabouço normativo vigente ou porque o agente age motivado por valores estereotipados e preconceituosos que banalizam a violência doméstica e familiar contra as mulheres. Nesta seção, o foco está na segunda "justificativa" de ação, ainda que na seção anterior tenham sido destacados alguns relatos que também remetem a esses valores (em especial no caso de conflito de competências e violência sem marcas). 
enquadrá-la na Lei Maria da penha. Além de o agressor ter tirado a vida da ex-esposa, também se matou;

3. Cidadã foi à DEAM para registrar um boletim de ocorrência pela agressão que sofreu. Sua pressão subiu muito e por isso sofreu um início de derrame. Ficou na DEAM mais de duas horas esperando para ser atendida e, quando conseguiu, o detetive que a atendeu a incentivou a não registrar o boletim e procurar o Fórum. O mesmo disse que ela resolveria isso no Fórum, que ele também tinha problemas conjugais e, por fim, a cidadã não conseguiu registrar o BO;

4. Senhora relata que foi ameaçada pelo seu companheiro com uma arma e expulsa de casa com os dois filhos. Relata que ao procurar a DEAM às $4 \mathrm{~h} 30 \mathrm{~min}$ da manhã, a delegada negou-se a registrar seu $\mathrm{BO}$ e falou para agredida que não havia motivo para denunciá-lo;

5. Cidadã relata estava sendo agredida pelo seu marido quando ligou para o número 190 da polícia relatando, pedindo ajuda. Segundo a cidadã, o policial que a atendeu não deu nenhuma importância ao que ela dizia e alegou não poder fazer nada por ela. A mesma, irritada com a situação, teria perguntado ao policial se ele estava naquela delegacia de enfeite. O policial, então, teria dito que ela seria presa por desacato. Ofendida, desistiu de pedir a ajuda da polícia;

6. Cidadã relata que foi a delegacia da mulher para registrar um BO, mas foi orientada a esperar que se agressor voltasse a agredi-la, ela poderia chamar o serviço emergencial 190.

7. Cidadã relata que registrou $\mathrm{BO}$ por violência doméstica na DEAM. Há duas semanas ela foi chamada à DEAM e foi the apresentada uma declaração sugerindo que ela desistisse do processo. 
Um outro conjunto de reclamações também nos remete à ideia da banalização da violência e de sua desqualificação enquanto crime ao trazerem como objeto central o descaso dos agentes públicos na realização de suas obrigações enquanto servidores do Estado. Neste caso, não há explicitamente uma manifestação de valores preconceituosos a respeito das convenções de gênero, mas um escamoteamento das reais intenções da recusa de atendimento, que parece sem qualquer justificativa cabível. Vejamos:

1. Cidadã está agora na porta da DEAM, onde já foi pela terceira vez registrar um BO baseado na Lei Maria da Penha, mas o escrivão disse-lhe que a delegada não iria registrar o boletim, alegando ter atendimentos mais urgentes para realizar;

2. Cidadã esteve na DEAM para registrar BO e a delegada se negou a registrá-lo, dizendo que acabara seu expediente e mandou a cidadã procurar outra delegacia;

3. A vítima foi até a delegacia (comum da polícia civil), e o cidadão que a atendeu se recusou a fazer o seu BO por motivo de dor no braço, que era pra cidadã esperar o próximo escrivão chegar. Quando o plantão trocou, o outro atendente disse que era apenas uma briga de casal e que a Lei Maria da Penha não funcionava naquela cidade como estava escrito no papel.

Chama a atenção, ainda, os relatos que tematizam a recusa dos atendimentos em casos de corporativismo policial, ou seja, casos em que o agressor é um policial militar ou civil e nos quais os boletins de ocorrência não são registrados e as mulheres em situação de risco continuam sem a sua segurança garantida. Além desses, há outros mais explicitamente caracterizáveis como de corrupção policial, em que os serviços de segurança são cobrados ou há suborno para não apenar os agressores e que demandam uma ação imediata junto às corregedorias de polícia para apuração e responsabilização dos agentes. 
1. Cidadã ligou para o 190. Estiveram no local três viaturas, porém se recusaram a prender o agressor devido ao mesmo ser policial. Alegaram que não colocariam as mãos em um colega de serviço;

2. Cidadã compareceu à delegacia comum para registrar um boletim de ocorrência por ter sofrido violência, e o delegado que estava de plantão se recusou a fazê-lo pelo fato do agressor ser policial civil;

3. Cidadã relata que sua irmã estava sendo agredida pelo marido. Quando solicitou a presença da polícia, um policial da DP informou que a delegacia estava superlotada e para levar o agressor eles teriam que pagar $\mathrm{R} \$ 30,00$ a diária;

4. Cidadão relata que o delegado recebeu propina do agressor de sua sobrinha para que não desse continuidade ao boletim de ocorrência e encaminhasse o processo ao Fórum. O mesmo já procurou junto ao Fórum o andamento e lá não consta processo.

\section{Considerações finais}

A necessidade de se constituir uma política de segurança pública que incorpore as especificidades das demandas das mulheres em toda a sua amplitude, para além das relativas à violência doméstica e familiar, é inconteste. Muito já se avançou, contudo, há ainda nesse campo muitas arestas a serem aparadas, sobretudo quando se leva em consideração os meandros das interações entre demandantes dos serviços de segurança pública e seus agentes. A análise ora apresentada objetivou fazer um primeiro esforço nessa direção ao lançar luzes sobre as sombras dessas situações retratadas pelas reclamações que chegam à Central Ligue 180 . 
Cabe ainda mencionar que, dentre o universo de relatos analisados, encontramos uma série deles que não teve espaço aqui por se tratar de reclamações que revelam o desconhecimento das reclamantes sobre o sistema de segurança e justiça. Elas refletem a insatisfação e frustração das reclamantes sobre a demora do andamento do processo de registro da ocorrência e os seus desdobramentos do que propriamente um mau atendimento nos serviços.

De forma geral, os agrupamentos das reclamações seguiram a maior ou menor ênfase dada à noção de que a violência doméstica e familiar contra as mulheres não é reconhecida como um crime, ou, no melhor dos casos, um crime de menor gravidade. Não podemos deixar de reiterar o nosso espanto por termos encontrado tais concepções mesmo entre as delegacias especializadas. Além dessa, há outras reiterações, só que agora nas práticas dos serviços sob análise aqui: o continuado não cumprimento da Lei Maria da Penha e a insistência de, face à existência dos serviços especializados, uma desobrigação dos demais a efetuarem bom atendimento. Esperamos, assim, que este texto venha a contribuir para transformar essa realidade.

\section{Referências}

ANISTIA INTERNACIONAL. Por trás do silêncio: experiências de mulheres com a violência urbana no Brasil. Porto Alegre, 2008. Disponível em: <http://www.amnesty.org/en/library/asset/ AMR19/001/2008/en/784c4e58-62f1-11dd-9756-f55e3ec0a600/ amr190012008por.pdf>. Acesso em: 1 maio 2015.

ARTICULAÇÃO DE MULHERES BRASILEIRAS (AMB). AMB e a Conferência de Segurança Pública. Articulando eletronicamente, n. 191, 8 maio 2009, anexo da seção Contextos. Disponível em: <http://www. articulacaodemulheres.org.br $>$. Acesso em: maio 2009.

BIANCARELLI, A. Assassinatos de mulheres em Pernambuco: violência e resistência em um contexto de desigualdade, injustiça e machismo. São Paulo: Publisher Brasil, Instituto Patrícia Galvão, 2006. 
BONETTI, A.; PINHEIRO, L. Primeiro ano da Lei Maria da Penha: algumas análises possíveis. [Brasília, DF], 2007. mimeo.

BONETTI, A.; PINHEIRO, L.; FERREIRA, P. Violência contra as mulheres e direitos humanos no Brasil: uma abordagem a partir do Ligue 180. In: ENCONTRO NACIONAL DE ESTUDOS POPULACIONAIS, 16., 2008. Anais... Caxambú: ABEP 2008.

BRASIL. Constituição Da República Federativa Do Brasil. Brasília: Senado Federal, 1988. Disponível em: <http: / www.planalto.gov.br/ ccivil_03/Constituicao/ConstituicaoCompilado.htm>. Acesso em: 2015.

BRASIL. Lei n. 10.714, de 13 de agosto de 2003. Autoriza o Poder Executivo a disponibilizar, em âmbito nacional, número telefônico destinado a atender denúncias de violência contra a mulher. Disponível em: <http://www.planalto.gov.br/ccivil_03/leis/2003/L10.714.htm>. Acesso em: 2015.

BRASIL. Lei 11.340 de 7 de agosto de 2006. Cria mecanismos para coibir a violência doméstica e familiar contra a mulher, nos termos do $§ 8^{\circ}$ do art. 226 da Constituição Federal, da Convenção sobre a Eliminação de Todas as Formas de Discriminação contra as Mulheres. Brasília, DF, 2006. Disponível em: <http://www.planalto.gov.br/ccivil_03/_ ato2004-2006/2006/lei/111340.htm>. Acesso em: 25 set. 2010.

BRASIL. Rede de Enfrentamento à Violência contra a Mulher. Brasília: Secretária de políticas para as mulheres, [20--]. Disponível em: <https://sistema3.planalto.gov.br//spmu/atendimento/atendimento mulher.php? uf=BA >. Acesso em: 2015.

CARRARA, S.; VIANNA, A.; ENNE, A. L.. 'Crimes de bagatela': a violência contra a mulher na justiça do Rio de Janeiro. In: CORRÊA, M. (Org.). Gênero e cidadania. Campinas: Núcleo de Estudos de Gênero Pagu, 2002. p. 71-112. (Coleção Encontros)

DEBERT, G.; GREGORI, M. F. As delegacias especiais de polícia e o projeto gênero e cidadania. In: CORRÊA, M. (Org.). Gênero e cidadania. Campinas: Núcleo de Estudos de Gênero Pagu, 2002. p. 9-19. (Coleção Encontros)

HARAWAY, D. Saberes localizados: a questão da ciência para o feminismo e o privilégio da perspectiva parcial. Cadernos Pagu, Campinas, n. 5, p. 7-41, 1995. 
HEILBORN, M. L.; SORJ, B. Estudos de gênero no Brasil. In: MICELI, S. (Org.). O que ler na ciência social brasileira (1970-1995) São Paulo: Sumaré; Capes; Anpocs, 1999. p. 183-223. v. 2.

INSTITUTO BRASILEIRO DE GEOGRAFIA E ESTATÍSTICA (IBGE). Censo demográfico. Rio de Janeiro, 2000.

INSTITUTO BRASILEIRO DE GEOGRAFIA E ESTATÍSTICA (IBGE). Pesquisa Nacional por Amostra de Domicílio (PNAD). Rio de Janeiro, 2007.

INSTITUTO DE PESQUISA ECONÔMICA APLICADA (IPEA). Direitos humanos, justiça e cidadania. Políticas sociais: acompanhamento e análise, Brasília, DF, ed. esp., n. 13, p. 229-279, 2006.

INSTITUTO DE PESQUISA ECONÔMICA APLICADA (IPEA). Igualdade de gênero. Políticas sociais: acompanhamento e análise, Brasília, n. 14, p. 227-250, 2007.

INSTITUTO DE PESQUISA ECONÔMICA APLICADA (IPEA). Igualdade de gênero. Políticas sociais: acompanhamento e análise, Brasília, n. 15, mar. p. 233-254, 2008a.

INSTITUTO DE PESQUISA ECONÔMICA APLICADA (IPEA). Igualdade de gênero. Políticas sociais: acompanhamento e análise, Brasília, n. 16, p. 283-306, 2008b.

INSTITUTO DE PESQUISA ECONÔMICA APLICADA (IPEA). Igualdade de gênero. Políticas sociais: acompanhamento e análise, Brasília, n. 17, v. 3, p. 201-246, 2009a. Disponível em: <http://www.ipea.gov. br/portal/images/stories/PDFs/politicas_sociais/bps_17_vol003_ completo.pdf $>$. Acesso em: 2015.

INSTITUTO DE PESQUISA ECONÔMICA APLICADA (IPEA). Situação atual e perspectivas do Pacto Nacional pelo Enfrentamento da Violência contra a Mulher. In: INSTITUTO DE PESQUISA ECONÔMICA APLICADA (IPEA). Brasil em desenvolvimento: estado, planejamento e políticas públicas. Brasília, DF, 2009b.

MACHADO, L. Z. Atender vítimas, criminalizar violências: dilemas das delegacias da mulher. Brasília, DF: UnB, 2002. (Série antropologia)

MARIANO, S. Feminismo, estado e proteção social: a cidadania das mulheres pobres. 293f. 2008. Tese (Doutorado em Sociologia) - Instituto de Filosofia e Ciências Humanas, Universidade Estadual de Campinas, 2008. 
MUNIZ, J. Os direitos dos outros e outros direitos: um estudo sobre a negociação de conflitos nas DEAMs. In: SOARES, L. (Org.). Violência e política no Rio de Janeiro. Rio de Janeiro: ISER/Relume Dumará, 1996.

PASINATO, W.; SANTOS, C. M. Mapeamento das delegacias da Mulher no Brasil. Campinas: Pagu/UniCamp, 2008. Disponível em: $<$ http:// www.observatorioseguranca.org/pdf/MAPEO_Brasil $\% 5 \mathrm{B1} \% 5 \mathrm{D} . \mathrm{pdf}>$ Acesso em: 20 nov. 2008.

PASINATO, W. P.; SANTOS, C. M. Violência contra as mulheres e violência de gênero: notas sobre estudos feministas no Brasil. São Paulo: [s.n., 2005]. Disponível em: <http://www.nevusp.org/ downloads/down083.pdf >. Acesso em: 2015.

RIFIOTIS, T. As delegacias especiais de proteção à mulher no Brasil e a judiciarização dos conflitos conjugais. Soc. estado, Brasília, DF, v. 19, n. 1, p. 85-119, jan./jun., 2004.

SOARES, B. Mulheres invisíveis: violência conjugal e novas políticas de segurança. Rio de Janeiro: Civilização Brasileira, 1999.

VIEIRA, M. S. Universo legal em ato: a construção de categorias jurídicas em torno da violência sexual. 191 f. 2007. Tese (Doutorado em Antropologia Social) - Instituto de Filosofia e Ciências Humanas, Universidade Federal do Rio Grande do Sul, Porto Alegre, 2007. 


\section{ANEXO - Tabelas e Quadro}

Tabela 1 - Distribuição dos serviços especializados de atendimento às mulheres em situação de violência, segundo tipo de serviço, por unidade da federação, 2009.

\begin{tabular}{|c|c|c|c|c|c|}
\hline & $\begin{array}{l}\text { CENTRO DE } \\
\text { REFERÊNCIA }\end{array}$ & $\begin{array}{l}\text { CASA } \\
\text { ABRIGO }\end{array}$ & $\begin{array}{l}\text { DEAM'S/ } \\
\text { PAM'S }\end{array}$ & $\begin{array}{c}\text { JUIZADOS E VARAS } \\
\text { ESPECIAIS }\end{array}$ & $\begin{array}{l}\text { TOTAL DE } \\
\text { SERVIÇOS }\end{array}$ \\
\hline SP & 31 & 14 & 129 & 18 & 192 \\
\hline MG & 9 & 5 & 47 & 0 & 65 \\
\hline RS & 9 & 4 & 39 & 1 & 53 \\
\hline RJ & 24 & 4 & 14 & 5 & 48 \\
\hline PR & 8 & 5 & 18 & 1 & 32 \\
\hline MA & 2 & 2 & 18 & 2 & 24 \\
\hline ES & 6 & 2 & 12 & 2 & 22 \\
\hline SC & 2 & 3 & 14 & 3 & 22 \\
\hline BA & 5 & 1 & 14 & 1 & 21 \\
\hline MS & 4 & 2 & 12 & 1 & 21 \\
\hline $\mathrm{CE}$ & 5 & 2 & 7 & 3 & 18 \\
\hline PA & 3 & 2 & 10 & 2 & 17 \\
\hline DF & 0 & 1 & 13 & 3 & 17 \\
\hline MT & 2 & 3 & 8 & 4 & 17 \\
\hline TO & 1 & 1 & 10 & 1 & 15 \\
\hline PE & 3 & 4 & 4 & 1 & 13 \\
\hline RO & 3 & 1 & 7 & 1 & 12 \\
\hline GO & 1 & 1 & 9 & 1 & 12 \\
\hline PB & 3 & 1 & 6 & 0 & 11 \\
\hline$A C$ & 4 & 2 & 2 & 1 & 9 \\
\hline $\mathrm{AM}$ & 0 & 1 & 6 & 2 & 9 \\
\hline $\mathrm{PI}$ & 1 & 2 & 5 & 0 & 9 \\
\hline RN & 2 & 1 & 5 & 1 & 9 \\
\hline $\mathrm{RR}$ & 0 & 1 & 1 & 6 & 8 \\
\hline SE & 1 & 1 & 4 & 1 & 7 \\
\hline AP & 1 & 1 & 2 & 1 & 6 \\
\hline $\mathrm{AL}$ & 2 & 1 & 2 & 1 & 6 \\
\hline TOTAL & 132 & 68 & 418 & 63 & 681 \\
\hline
\end{tabular}

Fonte: Brasil (2008). 
Quadro 1 - Perfil dos indivíduos que procuram a Central de Atendimento à Mulher para realizar reclamações, 2008.*

Mulheres: $98,42 \%$

Casadas ou em união estável: $59,8 \%$

Até nível médio completo: $89,1 \%$

De 21 a 40 anos: $67,2 \%$

Negras: $56,6 \%$

Da região Sudeste: $56,0 \%$

Fonte: Brasil (2008).

Nota: " Para o cálculo das distribuições, não foram contabilizados os registros de "não informados".

Tabela 2 - Distribuição dos atendimentos realizados pela Central de Atendimento à Mulher, por tipo, 2008.

\begin{tabular}{ccccc}
\hline \multirow{2}{*}{ TIPO DE ATENDIMENTO } & \multicolumn{2}{c}{2007} & \multicolumn{2}{c}{2008} \\
\cline { 2 - 5 } & $\mathrm{N}^{\circ} \mathrm{ABS}$. & $\%$ & $\mathrm{~N}^{\circ} \mathrm{ABS}$. & $\%$ \\
\hline Informação & 66.176 & 32,3 & 141.704 & 52,2 \\
Relato de Violência & 20.050 & 9,8 & 24.759 & 9,1 \\
Encaminhamento para Serviços & 117.436 & 57,3 & 102.146 & 37,7 \\
Reclamação & 904 & 0,4 & 1.959 & 0,7 \\
Sugestão & 138 & 0,1 & 165 & 0,1 \\
Elogio & 274 & 0,1 & 479 & 0,2 \\
Total & 204.978 & 100,0 & 271.212 & 100,0 \\
\hline
\end{tabular}

Fonte: Brasil (2008). 
Tabela 3 - Distribuição das reclamações recebidas pela Central de Atendimento à Mulher, por serviço, 2007 e 2008.

\begin{tabular}{ccccc}
\hline \multirow{2}{*}{ SERVIÇO } & \multicolumn{2}{c}{2007} & \multicolumn{2}{c}{2008} \\
\cline { 2 - 5 } & $\mathrm{N}^{\circ} \mathrm{ABS}$ & $\%$ & $\mathrm{~N}^{0} \mathrm{ABS}$. & $\%$ \\
\hline Departamento/Delegacia de Polícia & 307 & 34,0 & 908 & 46,4 \\
Delegacia Especializada de Atendimento à & 225 & 24,9 & 487 & 24,9 \\
Mulher & 94 & 10,4 & 353 & 18,0 \\
190 & 17 & 1,9 & 41 & 2,1 \\
Fórum & 16 & 1,8 & 22 & 1,1 \\
Serviços Especializados & 9 & 1,0 & 21 & 1,1 \\
Defensoria Pública & 1 & 0,1 & 5 & 0,3 \\
Organismos promoção e defesa dos direitos & 235 & $26,0^{*}$ & 122 & 6,2 \\
Outros & 904 & 100,0 & 1.959 & 100,0 \\
Total & & & & \\
\hline
\end{tabular}

Fonte: Brasil (2008).

Nota: *0 alto percentual da categoria "Outros" justifica-se pelo fato de que, até abril de 2007,0 registro era feito apenas como um atendimento de reclamação, mas não se registrava o serviço ao qual se referia, nem o seu conteúdo.

Tabela 4 - Distribuição dos indivíduos que realizaram reclamações na Central de Atendimento à Mulher, por sexo, 2008

\begin{tabular}{cccc}
\hline SEXO & $\mathrm{N}^{\circ}$ ABS & $\%$ & $\%$ SEM NI* \\
\hline Feminino & 1.928 & $98,42 \%$ & $98,62 \%$ \\
Masculino & 27 & $1,38 \%$ & $1,38 \%$ \\
Não Informada & 4 & $0,20 \%$ & \\
Total & 1.959 & $100,00 \%$ & $100,00 \%$ \\
\hline
\end{tabular}

Fonte: Brasil (2008).

Nota: *Distribuição calculada excluindo-se os casos não informados. 
Tabela 5 - Distribuição dos indivíduos que realizaram reclamações na Central de Atendimento à Mulher, por estado civil, 2008

\begin{tabular}{cccc}
\hline ESTADO CIVIL & N $^{\circ}$ ABS & $\%$ & $\%$ SEM NI* \\
\hline Casada/União estável & 1.046 & $53,39 \%$ & $59,81 \%$ \\
Solteira & 387 & $19,75 \%$ & $22,13 \%$ \\
Separada/divorciada & 259 & $13,22 \%$ & $14,81 \%$ \\
Viúva & 45 & $2,30 \%$ & $2,57 \%$ \\
Outros & 12 & $0,61 \%$ & $0,69 \%$ \\
Não Informada & 210 & $10,72 \%$ & \\
Total & 1.959 & $100,00 \%$ & $100,00 \%$ \\
\hline
\end{tabular}

Fonte: Brasil (2008).

Nota: *Distribuição calculada excluindo-se os casos não informados.

Tabela 6 - Distribuição dos indivíduos que realizaram reclamações na Central de Atendimento à Mulher, por cor/raça, 2008

\begin{tabular}{cccc}
\hline COR/RAÇA & $\mathrm{N}^{\circ}$ ABS. & $\%$ & $\%$ SEM NI* \\
\hline Negra & 923 & $47,12 \%$ & $56,56 \%$ \\
Parda & 747 & $38,13 \%$ & $45,77 \%$ \\
Preta & 176 & $8,98 \%$ & $10,78 \%$ \\
Branca & 677 & $34,56 \%$ & $41,48 \%$ \\
Amarela & 17 & $0,87 \%$ & $1,04 \%$ \\
Indígena & 15 & $0,77 \%$ & $0,92 \%$ \\
Não Informada & 327 & $16,69 \%$ & \\
Total & 1.959 & $100,00 \%$ & $100,00 \%$ \\
\hline
\end{tabular}

Fonte: Brasil (2008).

Nota: *Distribuição calculada excluindo-se os casos não informados. 
Tabela 7 - Distribuição dos indivíduos que realizaram reclamações na Central de Atendimento à Mulher, por faixa etária, 2008

\begin{tabular}{cccc}
\hline FAIXA ETÁRIA & $\mathrm{N}^{\circ}$ ABS. & $\%$ & $\% \mathrm{SEM} \mathrm{NI}^{*}$ \\
\hline Até 21 anos & 59 & $3,01 \%$ & $3,22 \%$ \\
21 a 30 & 612 & $31,24 \%$ & $33,41 \%$ \\
31 a 40 & 620 & $31,65 \%$ & $33,84 \%$ \\
41 a 50 & 353 & $18,02 \%$ & $19,27 \%$ \\
51 a 60 & 163 & $8,32 \%$ & $8,90 \%$ \\
Mais de 60 & 25 & $1,28 \%$ & $1,36 \%$ \\
Não Informada & 127 & $6,48 \%$ & \\
Total & 1.959 & $100,00 \%$ & $100,00 \%$ \\
\hline
\end{tabular}

Fonte: Brasil (2008).

Nota: *Distribuição calculada excluindo-se os casos não informados.

Tabela 8 - Distribuição dos indivíduos que realizaram reclamações na Central de Atendimento à Mulher, por nível de escolaridade, 2008

\begin{tabular}{cccc}
\hline ESCOLARIDADE & $\mathrm{N}^{\circ}$ ABS & $\%$ & $\%$ SEM NI* \\
\hline Ensino fundamental & 809 & $41,30 \%$ & $47,48 \%$ \\
Ensino médio & 694 & $35,43 \%$ & $40,73 \%$ \\
Ensino superior & 186 & $9,49 \%$ & $10,92 \%$ \\
Analfabeta & 15 & $0,77 \%$ & $0,88 \%$ \\
Não Informada & 255 & $13,02 \%$ & \\
Total & 1.959 & $100,00 \%$ & $100,00 \%$ \\
\hline
\end{tabular}

Fonte: Brasil (2008).

Nota: *Distribuição calculada excluindo-se os casos não informados. 
Tabela 9 - Distribuição dos indivíduos que realizaram reclamações na Central de Atendimento à Mulher, por unidade da federação. Brasil, 2008

\begin{tabular}{|c|c|c|c|}
\hline UF & $\mathrm{N}^{\circ}$ ABS. & $\%$ & $\%$ SEM NI* \\
\hline SP & 684 & $34,92 \%$ & $35,28 \%$ \\
\hline RJ & 236 & $12,05 \%$ & $12,17 \%$ \\
\hline MG & 165 & $8,42 \%$ & $8,51 \%$ \\
\hline RS & 121 & $6,18 \%$ & $6,24 \%$ \\
\hline $\mathrm{BA}$ & 117 & $5,97 \%$ & $6,03 \%$ \\
\hline DF & 87 & $4,44 \%$ & $4,49 \%$ \\
\hline PR & 85 & $4,34 \%$ & $4,38 \%$ \\
\hline GO & 72 & $3,68 \%$ & $3,71 \%$ \\
\hline PA & 66 & $3,37 \%$ & $3,40 \%$ \\
\hline PE & 43 & $2,19 \%$ & $2,22 \%$ \\
\hline ES & 35 & $1,79 \%$ & $1,81 \%$ \\
\hline SC & 35 & $1,79 \%$ & $1,81 \%$ \\
\hline CE & 29 & $1,48 \%$ & $1,50 \%$ \\
\hline MA & 25 & $1,28 \%$ & $1,29 \%$ \\
\hline PB & 21 & $1,07 \%$ & $1,08 \%$ \\
\hline $\mathrm{AL}$ & 19 & $0,97 \%$ & $0,98 \%$ \\
\hline RN & 19 & $0,97 \%$ & $0,98 \%$ \\
\hline MT & 17 & $0,87 \%$ & $0,88 \%$ \\
\hline SE & 16 & $0,82 \%$ & $0,83 \%$ \\
\hline TO & 12 & $0,61 \%$ & $0,62 \%$ \\
\hline MS & 10 & $0,51 \%$ & $0,52 \%$ \\
\hline RO & 8 & $0,41 \%$ & $0,41 \%$ \\
\hline$A M$ & 6 & $0,31 \%$ & $0,31 \%$ \\
\hline PI & 5 & $0,26 \%$ & $0,26 \%$ \\
\hline AP & 4 & $0,20 \%$ & $0,21 \%$ \\
\hline$A C$ & 1 & $0,05 \%$ & $0,05 \%$ \\
\hline $\mathrm{RR}$ & 1 & $0,05 \%$ & $0,05 \%$ \\
\hline $\mathrm{NI}$ & 20 & $1,02 \%$ & \\
\hline Total & 1.959 & $100,00 \%$ & $100,00 \%$ \\
\hline
\end{tabular}

Fonte: Brasil (2008).

Nota: *Distribuição calculada excluindo-se os casos não informados. 


\title{
A LEI MARIA DA PENHA E SUA APLICAÇÃO NAS DEAMs DE SALVADOR reflexões sobre o que pensam e dizem as mulheres em situação de violência
}

\author{
Ermildes Lima da Silva \\ Simone Oliveira de Lacerda \\ Márcia Santana Tavares
}

\section{Introdução}

A violência contra as mulheres configura-se como uma violação dos direitos humanos, uma ameaça a seus direitos à vida, à saúde, à integridade física e à liberdade. É um fenômeno que se manifesta através de diferentes modalidades: psicológica, moral, simbólica, sexual, patrimonial e física. No entanto, não ocorre de forma isolada ou aleatória, atinge as mulheres em diversas partes do mundo; isso porque encontra sustentáculo na organização social dos sexos, sendo praticada contra as mulheres em relações de poder historicamente desiguais. Para melhor compreendermos 
esse fenômeno, é fundamental a discussão da construção socio-histórica de gênero.

Tanto a violência quanto o gênero são construções histórico-sociais e culturais em que o poder entre mulheres e homens é distribuído de forma assimétrica. As relações de gênero são relações sociais e de poder que um sexo exerce sobre outro. (SCOTT, 1995) Além de englobarem as relações entre homem-mulher, envolvem também relações sociais entre um mesmo sexo (homem-homem, mulher-mulher). No entanto, a violência masculina contra mulheres, histórica e numericamente, se sobressai, revelando-se não apenas como fenômeno estruturado, "mas também como fator estruturante da organização social de gênero nas sociedades contemporâneas." (SAFFIOTI; ALMEIDA, 1995)

A violência de gênero, inclusive em suas modalidades familiar e doméstica, extrapola fronteiras geográficas, ignorando as fronteiras de classe social, raça/etnia, graus de instrução, idade/geração e orientação sexual, compondo uma realidade global que tem tomado proporções cada vez mais alarmantes.

A naturalização, por parte da sociedade, de agressões cometidas pelos homens contra mulheres, especialmente quando se trata de um relacionamento afetivo, e das mulheres contra seus filhos, compondo uma hierarquia familiar, gerou durante muitos anos a ideia de que o espaço privado era invulnerável e inviolável por parte do setor público (SAFFIOTI, 1999), sendo mantida pela clássica frase: "Em briga de marido e mulher, ninguém mete a colher.” (SILVA; LACERDA; TAVARES, 2012, p. 2)

Durante a década de 1970 e 1980, os movimentos de mulheres e feministas, articulados com o movimento em defesa dos direitos humanos, levaram para o cenário público as suas reinvindicações. Dentre as pautas, cobrava-se o reconhecimento do Estado e da sociedade do direito a uma vida sem violência, a punição dos agressores e o reconhecimento da equidade de gênero, ou 
seja, "houve uma politização da violência doméstica e familiar." (SARDENBERG; TAVARES, 2012, p. 2)

A década de 1980 traz mudanças de ordem social e jurídica, o movimento junta-se aos movimentos internacionais e, devido à pressão exercida pelas mulheres, em 1985, foi implantada a primeira Delegacia Especializada de Atendimento à Mulher (DEAM), em São Paulo. Em 1988, a Constituição Federal, no inciso I do artigo $5^{\circ}$, proclamou que "homens e mulheres são iguais em direitos e obrigações”, ao mesmo tempo em que assegurou no $§ 8^{\circ} \mathrm{o}$ direito à assistência do Estado aos membros do grupo familiar, através da criação de mecanismos capazes de impedir a violência na esfera de suas relações.

No tocante à criação de legislações específicas, em 1995, com a Lei n. 9.099, foram fundados os Juizados Especiais Criminais (JECRIMs), responsáveis por processar e julgar crimes, como delitos de lesões corporais leves e ameaças, com menor potencial ofensivo, cujos agressores não eram presos, apenas pagavam multas, no geral, cestas básicas. (BRASIL, 1995) Essa lei foi alvo de várias críticas, as organizações feministas debateram e produziram conhecimentos a respeito, chegando à conclusão de que a forma proposta pela lei representava um retrocesso no enfrentamento da violência contra a mulher. ${ }^{1}$

Nesse sentido, os movimentos de luta feministas e de mulheres elaboraram um projeto de lei que incluía a proposta de revogar a competência dos JECRIMs para julgar os casos de violência doméstica e familiar contra a mulher. O projeto de lei foi encaminhado ao Executivo Federal em 2004, e a Lei de Enfrentamento à Violência Doméstica e Familiar contra a Mulher - Lei n. 11.340, conhecida como Lei Maria da Penha, foi sancionada em 2006, entrando em vigor no mesmo ano. (TAVARES, 2010)

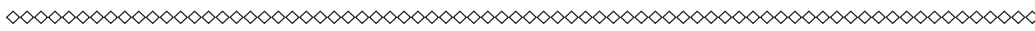
1 Para saber mais sobre os JECRIMs, sugere-se a consulta de Barsted (2007). 
A referida lei inova ao objetivar a criação de "mecanismos para coibir e prevenir a violência doméstica e familiar contra a mulher" no artigo $1^{\circ}$, configurando, assim, "uma nova realidade jurídica para o enfrentamento da violência contra as mulheres." (PASINATO, 2009, p. 6) Ao criar uma lei específica para prevenir, combater e punir a violência doméstica e familiar contra as mulheres, tanto o Estado quanto a sociedade atribuíram visibilidade social e política a essa questão. (SILVA; LACERDA; TAVARES, 2012)

Todavia, apesar dos avanços, ainda há muitos desafios a serem superados para a efetivação dessa lei. Diante disso, a Secretaria Especial de Políticas para Mulheres (SPM), com o propósito de cooperar para a efetivação da Lei Maria da Penha, tem criado projetos que visam monitorar a aplicação da lei. Um desses projetos resultou na criação de um observatório, o Observatório da Lei Maria da Penha (Observe). Instalado em 2007, o Observe é um consórcio de entidades não governamentais e núcleos de pesquisa de universidades, liderado pelo Núcleo de Estudos Interdisciplinares sobre a Mulher da Universidade Federal da Bahia (NEIM/UFBA), e tem como finalidade principal acompanhar, a partir da coleta, análise e publicação de informações, o processo de efetivação da Lei Maria da Penha.

Na sequência, apresentamos os resultados de uma das atividades de monitoramento do Observe: uma pesquisa desenvolvida nos serviços considerados como "porta de entrada" para aplicação da lei, as Delegacias Especializadas de Atendimento à Mulher de Salvador/BA, buscando refletir sobre os procedimentos e encaminhamentos no âmbito institucional e a compreensão dessas mulheres sobre a violência contra a mulher e sobre a Lei Maria da Penha.

\section{Metodologia}

Esta pesquisa, realizada por alunas do Curso de Serviço Social da UFBA, consiste em uma atividade do Programa Institucional de 
Bolsas de Iniciação Cientifica (PIBIC), iniciada em agosto de 2011, e compõe uma das etapas da pesquisa intitulada "A implementação da Lei Maria da Penha e o acesso das mulheres à justiça em SalvadorBahia", financiada pelo Conselho Nacional Desenvolvimento Científico e Tecnológico (CNPq). Tal pesquisa visa avaliar como a referida lei vem sendo aplicada sob o ponto de vista das mulheres em situação de violência, que buscam os serviços de proteção e apoio e dos executores da política de enfrentamento.

A pesquisa compreendeu dois momentos que se complementam: o primeiro é referente ao levantamento bibliográfico e documental sobre a temática de gênero e violência, que reuniu o aporte necessário para compreensão da violência contra as mulheres. O segundo momento, iniciado em março de 2012 e finalizado em agosto do mesmo ano, constitui a pesquisa empírica realizada através da aplicação de entrevistas semiestruturadas com 26 mulheres, logo após serem atendidas nas DEAMs de Salvador, de forma a identificar os procedimentos e encaminhamentos no âmbito institucional e a compreensão dessas mulheres sobre a violência contra a mulher e sobre a Lei Maria da Penha. Foram aplicadas também entrevistas com profissionais que trabalham no atendimento a essas mulheres, assim como observação do atendimento institucional.

Cabe mencionar que, antes das entrevistas, esclarecemos para as possíveis informantes o objetivo da pesquisa, solicitando que assinassem um termo de consentimento, conforme recomenda a Resolução n. 196 (BRASIL, 1996), apesar de algumas acharem desnecessário, por entenderem que a própria gravação de perguntas e respostas já indicava sua anuência. Na ocasião, comprometemo-nos também com a garantia do anonimato, desde a troca de nomes e a omissão de quaisquer dados que pudessem identificá-las até a transcrição das entrevistas, pelas quais seríamos responsáveis, de forma a evitar que outras pessoas tivessem acesso às informações. 
Com relação aos funcionários das DEAMs, encaminhamos um ofício às delegadas informando sobre o objetivo da pesquisa e solicitando autorização para que pudéssemos colher informações com os funcionários, bem como acompanhar o atendimento e observar a rotina institucional. Foram muitas as idas e vindas até conseguirmos iniciar a coleta de dados em virtude de diversos fatores, dentre os quais a dificuldade de obtermos a referida autorização: a delegada não estava disponível ou tinha saído, questionava nossa pretensão de entrevistarmos os funcionários e excluí-la, já que seria a pessoa mais qualificada para prestar informações sobre o serviço. Inclusive, no período da pesquisa, houve algumas substituições, o que implicou uma retomada de explicações e negociações para obter uma nova autorização.

Outra questão que contribuiu para retardar o início da pesquisa de campo é relativa à resistência de uma das delegadas quanto à coleta de informações com as mulheres, pois entendia que não poderíamos fazê-la sem que conhecesse e aprovasse o roteiro de entrevista. Seu pedido se mostrava inoportuno, pois elas seriam abordadas após saírem da DEAM, mas compreensível, uma vez que, na ocasião, as DEAMs estavam sendo visitadas por membros da Comissão Parlamentar Mista de Inquérito (CPMI) da Violência, que elaborava um dossiê sobre o atendimento à violência contra as mulheres em Salvador e região metropolitana da capital, o que gerou certo desconforto, mas nada que nos impedisse de manter um relacionamento ético e cordial, prometendo-lhe um retorno acerca dos resultados da pesquisa, sobre os quais refletiremos no próximo tópico.

\section{Socializando resultados}

Salvador, capital baiana, caracteriza-se como a terceira cidade mais populosa do Brasil, no entanto, conta apenas com duas 
DEAMs, uma localizada no bairro de Engenho Velho de Brotas e a outra em Periperi, no Subúrbio Ferroviário de Salvador. A primeira Delegacia foi instalada em 1986, no bairro de Brotas e, somente em 2008, foi instalada a segunda DEAM, em Periperi. Durante o processo de coleta de dados, pudemos perceber o quanto duas DEAMs são insuficientes para atender a vasta demanda das mulheres que para lá se dirigem em busca de proteção.

Apenas no ano de 2011, a Delegacia de Brotas² registrou 2404 ocorrências de lesão corporal; 309 casos de calúnia, injúria e/ou difamação; 32 estupros e 3018 ameaças. Nos primeiros meses do ano de 2012, de janeiro a março, foram registradas 959 ocorrências de lesão corporal; 142 casos de calúnia, injúria e/ou difamação; 6 estupros e 1068 ameaças. Os dados ilustram uma realidade complexa, marcada pela densidade da problemática da violência contra a mulher na capital, bem como revelam a alta demanda pelo serviço, que associada ao quadro insuficiente de funcionários, resulta, entre outros fatores, na morosidade do atendimento e na insatisfação daquelas mulheres que recorrem ao serviço.

No tocante à infraestrutura das Delegacias, identificamos precariedades. Na DEAM de Periperi, as salas são pequenas e o número de cadeiras da sala de espera é insuficiente, não havendo um espaço físico específico para a Delegacia, isto é, ela fica situada em um Complexo Policial que agrega em um mesmo prédio unidades da Polícia Civil, Polícia Militar, o Corpo de Bombeiros e o Serviço de Atenção a Pessoas em Situação de Violência (VIVER). Durante as visitas a essa DEAM, deparamo-nos com situações diferenciadas, desde policiais conduzindo presos algemados, pessoas bêbadas deitadas no corredor da Delegacia Militar e até repórteres da imprensa baiana, o que deixava as mulheres intimidadas e pouco à vontade.

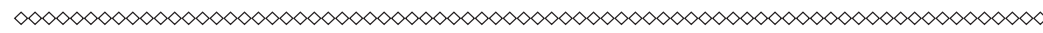
2 A Delegacia de Periperi não disponibilizou dados estatísticos. 
A Delegacia de Brotas dispõe de melhor infraestrutura, as salas são amplas e climatizadas, possui espaço lúdico para as crianças; há o setor de triagem na sala de espera, possui televisão e murais informativos, tanto sobre a Lei Maria da Penha, como relativos aos procedimentos da Delegacia e da Rede de Serviço, além de possuir uma caixa designada para que as usuárias depositem sugestões de atendimento.

Uma característica percebida em ambas as delegacias referente à infraestrutura é a falta de privacidade no atendimento. A sala de espera é próxima ao local de registro da ocorrência, há livre acesso de todos que chegam às DEAMs e constante movimentação de funcionários, que frequentemente interrompem os depoimentos. ${ }^{3}$

O acesso a ambas as delegacias é difícil, uma vez que ficam localizadas em regiões em que o transporte público é limitado, em áreas residenciais, distante de outros Serviços da Rede, e faltam sinalizações que permitam às pessoas saberem a localização exata das DEAMs.

Dentre as dificuldades encontradas para a coleta de dados, a maior delas foi o excesso de burocracia e hierarquia do serviço. Para obter informações básicas, passamos por vários setores e fomos encaminhadas a diferentes pessoas nas Delegacias, pois há uma definição muito rígida das atividades que devem ser desempenhadas por cada setor interno: cartório, delegada, sala de ocorrência, setor psicossocial; ${ }^{4}$ cada um tem seus próprios afazeres e funções, o trabalho não é realizado de forma articulada, o que gera a concentração de informações e provoca a morosidade no atendimento. (SILVA; LACERDA; TAVARES, 2012) Outra ressalva é

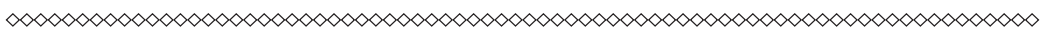

3 A falta de privacidade é um dos problemas comuns às DEAMs no Nordeste. (TAVARES; SARDENBERG; GOMES, 2011)

4 Apenas a DEAM de Brotas possui o setor psicossocial, com psicólogas e assistentes sociais. A Delegacia de Periperi possui apenas assistente social. 
referente a sucessivas trocas de Delegadas no período de março a agosto de 2012 na Delegacia de Brotas.

Em relação ao quadro funcional, as entrevistas realizadas com as mulheres e com os próprios profissionais, assim como as observações assistemáticas do atendimento, nos revelaram o despreparo da equipe técnica para atuar na área da violência contra a mulher. A falta de capacitação e de envolvimento com a temática ${ }^{5}$ é evidente, uma vez que o corpo profissional é composto por policiais civis que trabalharam anteriormente na Delegacia de Furtos e Roubos, Penitenciárias, entre outras categorias, que demonstram pouco ou nenhum conhecimento sobre a questão de gênero e a violência doméstica e familiar contra a mulher, tendo suas orientações baseadas no senso comum.

Todos esses fatores contribuem para atendimentos muitas vezes preconceituosos e desumanizados, como é o caso de Jandira, ${ }^{6}$ que depois de ter ido à Delegacia uma primeira vez, retorna para fazer outra queixa do mesmo agressor, conforme revelou na ocasião:

Eu não considerei um bom atendimento porque parecia que eu não era a vítima. Eu fiquei muito nervosa porque quando eu cheguei aqui é muita pressão em cima da mulher, eu acho que não deveria ser desse jeito. Eles perguntam: porque você 'tá' com ele? Porque não tem onde ficar? Porque não sai de casa? Porque não sei o que lá [...]. A mulher 'tá' ali não é porque quer, passando por certas naquele local.

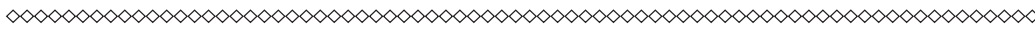

5 Pesquisa desenvolvida pelo Observe (SARDENBERG; GOMES; TAVARES, 2011) nas capitais brasileiras e no Distrito Federal constatou que, apesar do investimento em cursos de capacitação, principalmente acerca das questões de gênero, raça/etnia e violência contra as mulheres, são poucos os funcionários que participam desses cursos. Ademais, as DEAMs não valorizam a capacitação e, por isso, não mantêm registros referentes a quem participa e quais os cursos mais procurados.

6 Os nomes das mulheres citadas são fictícios, de forma a garantir seu anonimato. 
De fato, durante nossas idas a campo, pudemos observar cenas em uma mesma delegacia que nos chamaram a atenção. De maneira especial, uma na qual a queixosa Carina se mostrava indecisa quanto ao registro da denúncia, pelo fato de os policiais orientarem que, com a Lei Maria da Penha, a queixa não poderá ser retirada. No entanto, o tom incisivo e mecânico utilizado pelos profissionais para prestar orientação soa intimidador. Depois de ouvir a explicação, Carina afirmou que não iria registrar a queixa. Então, a policial que a atendia, de forma impaciente, verbalizou que se ela "preferia ficar nessa situação", ela se eximia de qualquer responsabilidade, pois não podia fazer nada - o que evidencia a inexistência de uma escuta qualificada.

Outra situação aconteceu com Gilda, que havia dormido na Delegacia e estava aguardando para falar com a delegada há mais de 15 horas, sem ter recebido qualquer orientação sobre medidas protetivas e sobre seus direitos assegurados em lei, conforme explica:

Eu 'tou' aqui esperando, eu cheguei aqui ontem umas 10 e pouca da noite. Chegou aqui, dei a queixa, assinei tudo e aí: 'ah e agora, a senhora vai pra onde?' Eu vou dormir aqui porque se eu voltar pra casa dele, ele vai me matar, vai ser pior e eu num tenho outro lugar pra ir aí. Então, ele disse: 'fica naquela cadeira ali, sentada.' E eu fiquei no corredor, com minha filha no colo, a noite toda, com fome, com frio, suja. Nós tomamos banho ontem meio dia e estamos aqui até hoje, com fome. Um diz uma coisa, outro diz outra, eu continuo aqui.

Em outra ocasião, presenciamos a aflição de Jorge, cuja mãe, Marinalva, estava presa dentro de casa e o agressor ameaçava matá-la. Jorge solicitava que fossem policiais até o local para flagrar o agressor e garantir proteção policial a Marinalva, conforme preceitua a Lei Maria da Penha. No entanto, a Delegacia estava 
sem viaturas e, embora sua residência fosse localizada no mesmo bairro, os agentes se recusaram a acompanhá-lo. Percebemos que uma funcionária ligou para a Delegada e expôs a situação, mas, em seguida, informou a Jorge que a Delegada estava ocupada, não tinha mais policiais no serviço, orientando apenas que ligasse para o 190, o que claramente demonstra descaso e omissão.

No tocante à morosidade do atendimento, o tempo de espera entre o registro da ocorrência e da audiência chega a mais de seis meses. Na última ida à Delegacia, presenciamos situações diversas relatadas pelas mulheres: "eu vim aqui em janeiro, só que foi 'marcado' a audiência pra agora [agosto]"; Neide questiona: "se você está sendo ameaçada, se você vem procurar uma instituição dessa, é porque você precisa de uma solução rápida. Eu não posso ficar esperando porque tudo pode acontecer." Mas, em outro momento, observamos que Dora também havia registrado queixa e, diferentemente de Antonieta e Neide, sua audiência fora marcada na mesma semana. Procuramos saber dos profissionais quais os critérios para a marcação das audiências. No entanto, as respostas que nos deram foram insatisfatórias e diferem das observações feitas em campo; justificaram dizendo que a morosidade era um problema enfrentado pela gestão passada e, com a mudança recente para a nova gestão, havia mais agilidade nos processos. ${ }^{7}$

As mulheres entrevistadas, no geral, mostraram-se dispostas a colaborar para a concretização da pesquisa. Observou-se que, para algumas delas, o período da entrevista significava o momento em que alguém lhes dava atenção, escutava atentamente suas

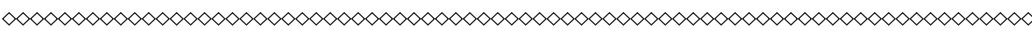

7 É importante frisar que, durante as visitas realizadas pela Comissão Parlamentar Mista de Inquérito, a morosidade do atendimento foi algo fortemente criticado. A entrevista que aponta agilidade do serviço foi realizada depois da visita da comissão. Além disso, coincidentemente ou não, após a visita da CPMI, a delegada titular foi exonerada, levando o Grupo de Trabalho (GT) da Rede de Atenção às Mulheres em Situação de Violência a enviar uma carta à Diretora de Enfrentamento à Violência contra as Mulheres da Secretaria de Políticas para as Mulheres da Presidência da República, expondo a situação encontrada na DEAM e seu estranhamento quanto à referida exoneração. 
histórias de vida e dificuldades em romper com o ciclo de violência. Era o momento em que se sentiam à vontade para desabafar sobre a morosidade e desatenção do atendimento policial.

Quanto ao perfil dessas mulheres, há diversidade, uma vez que a violência contra a mulher ignora graus de instrução, classe social, raça/etnia e idade/geração. Nesse sentido, devemos caracterizar a amostra obtida nas entrevistas para melhor compreensão de seus resultados. Referente à faixa etária, encontramos o seguinte resultado:

Quadro 1 - Idade das Mulheres

\begin{tabular}{|ccc|}
\hline FAIXA ETÁRIA & FREQUÊNCIA & $\%$ \\
\hline 18 a 29 & 19 & 46,2 \\
30 a 49 & 09 & 34,6 \\
40 a 50 & 05 & 19,2 \\
TOTAL & 26 & 100 \\
\hline
\end{tabular}

Fonte: Pesquisas diretas nas Delegacias Especiais de Atendimento à Mulher de Salvador (2011-2012).

Conforme apresentado na tabela, as agressões acontecem em todas as faixas etárias exibidas, registrando-se maior incidência na faixa de 18 a 29 anos, seguida de mulheres entre 30 a 49 anos. Ao interpretar esses dados, é importante considerar que a faixa etária que registrou maior procura às Delegacias de Salvador coincide com pesquisas anteriores desenvolvidas pelo Observe ${ }^{8}$ na capital, mais precisamente aquela que corresponde à fase reprodutiva e de maior inserção feminina no mercado de trabalho, com maior acesso a espaços de sociabilidade e à informação veiculada pelas campanhas midiáticas.

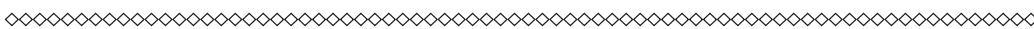

8 Ver, por exemplo, Soares (2011) e Leão (2011). Nas capitais brasileiras, de acordo com outra pesquisa do OBSERVE (TAVARES; GOMES; SARDENBERG, 2011), a faixa etária predominante está concentrada entre 30 e 39 anos e 18 a 29 anos. Essa situação só se inverte na região Norte, onde $52 \%$ das mulheres entrevistadas se encontram na faixa de 18 a 29 anos, especialmente em Manaus $(68 \%)$. 
No que se refere à raça/etnia, verificou-se uma maior incidência de mulheres que se definem negras, conforme o quadro a seguir: Quadro 2 - Raça/Etnia das Mulheres

\begin{tabular}{|ccc|}
\hline RAÇA/ETNIA & FREQUÊNCIA & $\%$ \\
\hline Branca & 03 & 11,5 \\
Parda & 07 & 26,9 \\
Negra & 14 & 53,8 \\
Morena $^{9}$ & 02 & 7,7 \\
TOTAL & 26 & 100 \\
\hline
\end{tabular}

Fonte: Pesquisas diretas nas Delegacias Especiais de Atendimento à Mulher de Salvador (2011-2012).

Durante a pesquisa, muitas mulheres se mostravam confusas quanto à raça/cor. É sabido que Salvador possui uma vasta miscigenação e a presença de negros é relevante, entre outros fatores, o que pode explicar a recorrência a maior incidência de mulheres negras. As pesquisas desenvolvidas nas DEAMs por Soares (2011) revelam que $56 \%$ se autodeclaram pardas e $40 \%$ negras, enquanto para Leão (2011), as mulheres entrevistadas se autorrepresentam de forma inversa, isto é, $56 \%$ como pardas e $40 \%$ negras. Contudo, se atentarmos para a adoção do Instituto Brasileiro de Geografia e Estatística (IBGE) da forma classificatória do movimento negro, para o qual pretos e pardos são considerados, podemos afirmar que a população investigada, em quase sua totalidade $(96 \%)$, declarou-se como negra.

No tocante à escolaridade, identificou-se um maior percentual de mulheres com o ensino médio completo, principalmente referente à faixa etária de 18 a 29 anos:

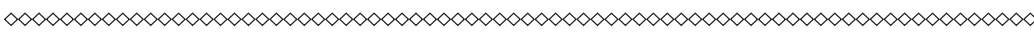
9 As questões eram abertas, as mulheres diziam a cor com a qual se identificavam livremente. 
Quadro 3 - Escolaridade das Mulheres

\begin{tabular}{|ccc|}
\hline ESCOLARIDADE DA VítIMA & FREQUÊNCIA & $\%$ \\
\hline Fundamental incompleto & 2 & 7,7 \\
Fundamental completo & 2 & 7,7 \\
Médio incompleto & 4 & 15,4 \\
Médio completo & 1 & 3,8 \\
$2^{\circ}$ grau incompleto & 5 & 19,3 \\
$2^{\circ}$ grau completo & 8 & 30,8 \\
Nível técnico & 2 & 7,7 \\
Graduação & 1 & 3,8 \\
Pós-graduação & 1 & 3,8 \\
TOTAL & 26 & 100 \\
\hline
\end{tabular}

Fonte: Pesquisas diretas nas Delegacias Especiais de Atendimento à Mulher de Salvador (2011-2012).

Conforme apresentado no quadro, podemos observar que o grau de instrução das mulheres que recorrem ao serviço é relativamente baixo, apesar de o maior índice corresponder ao $2^{\circ}$ grau completo, ao contrário dos dados levantados por Soares (2011) e Leão (2011), cujo índice mais representativo, $46 \%$, corresponde ao ensino médio. No entanto, os dados ressaltam, também, que a violência doméstica e familiar contra a mulher ocorre independente dos níveis de escolaridade.

Em relação ao conhecimento das mulheres sobre a Lei Maria da Penha, para a grande maioria, é baseado no que ouviram falar pela televisão e por outdoors espalhados pela cidade, daí nos depararmos numa das DEAMs com uma mulher à procura de "D. Maria da Penha”, associando a lei à figura física de uma mulher que estaria ali e a quem poderia se dirigir. Outro fator ocasionado pelo desconhecimento é a associação da violência apenas à agressão física, conforme evidencia o seguinte depoimento: “Eu não sofro violência! Foi xingamento! Só pequenas palavras que agridem, principalmente a mulher, né? Que os nomes que ele me xingou, foi horrivel." 
Os xingamentos e as palavras magoam e humilham, evidenciam desrespeito e desprezo, mas mesmo assim, a violência não é considerada como tal, pois é intangível. Isso está relacionado à ideia de que a violência só se configura como tal quando as marcas são visíveis. Essa interpretação equivocada também é feita pelos agentes policiais, o que indica desconhecimento sobre a Lei Maria da Penha e a tipologia da violência perpetrada contra as mulheres. Conforme revela Luana:

Fui encaminhada para o IML, mas eu mesma desisti, porque eu conversando com o policial, ele disse que eu não 'tava' com manchas no corpo, entendeu?! Só porque ele tinha me batido e tal, mas aí eu mesmo desisti.

Ainda em relação ao conhecimento dessas mulheres, a maioria afirmou desconhecer outros serviços que atendessem mulheres em situação de violência, o que nos leva a perceber que o foco na denúncia, principalmente promovido pelas campanhas midiáticas, evidencia apenas os aspectos legais da violência contra a mulher. O desconhecimento acerca de outros serviços também pode ser verificado nos encaminhamentos realizados pelos profissionais das Delegacias, pois as mulheres são orientadas apenas para realização de exame no Instituto Médico Legal (IML), o que não deixa de ser um órgão policial.

No que se refere à efetividade do atendimento, é nítida a ausência de intersetorialidade e articulação da rede de proteção às mulheres, pois, entre as entrevistadas, apenas uma foi encaminhada para um serviço externo, a Defensoria Pública. Não registramos orientações e informações dadas pelas/os agentes policiais quanto à existência de trabalhos desenvolvidos pelas Instituições que compõem a Rede. Diante da falta de articulação entre os serviços, percebemos que a rede de proteção não tem efetividade, já 
que os órgãos funcionam isoladamente, o que denota um equívoco: tratar a violência apenas como uma questão policial e jurídica. (SILVA; LACERDA; TAVARES, 2012)

\section{Observações finais}

Embora a lei represente uma conquista e um avanço no combate à violência contra a mulher, não podemos ocultar os desafios para a sua efetivação, dentre os quais se destacam: a carência na infraestrutura dos serviços que a executam; a deficiência na capacitação dos profissionais que trabalham em espaços que atendem mulheres em situação de violência; a insuficiência de articulação entre as redes de serviço e apoio; a morosidade dos atendimentos; e a forma como a lei é divulgada, focando apenas na questão da denúncia.

Todavia, não podemos deixar de salientar que um dos fatores que também contribui para o descumprimento da Lei Maria da Penha é o desconhecimento das mulheres sobre seus direitos e sobre a própria lei. (SARDENBERG; TAVARES, 2012, p. 12) Nas entrevistas, pudemos notar que elas até sabem da existência da lei, divulgada através de campanhas televisivas e/ou programas de rádio, nos quais ouvem falar que é para "defender e proteger a mulher”, mas desconhecem que direitos lhes são assegurados.

Diante da realidade apresentada, observamos que as mulheres que procuraram essa "defesa e proteção" nas DEAMs de Salvador sentem-se desprotegidas e decepcionadas com o atendimento recebido, uma vez que elas veem as delegacias como um lugar de apoio e ruptura com o ciclo de violência, porém, após o atendimento, seu sentimento é de descrença e desilusão, conforme anuncia Elza: “o que eu ouvir falar não é nada que eu 'tou' vendo aqui, não." 
Por essa razão, entendemos que as atividades de monitoramento são imprescindíveis, pois podem suscitar questionamentos e reflexões acerca dos desafios a serem enfrentados para a efetiva aplicação da Lei Maria da Penha, além de subsidiarem a formulação e implementação de políticas públicas de enfrentamento à violência. Finalmente, consideramos que ainda há muito a observar e socializar entre pesquisadores, gestores, formuladores e executores de políticas públicas, mas principalmente entre as usuárias dessas políticas.

\section{Referências}

BARSTED, L. L. A resposta legislativa à violência contra as mulheres. In: ALMEIDA, S. (Org.). Violência de gênero e políticas públicas. Rio de Janeiro: Ed. UFRJ, 2007. (Didáticos)

BRASIL. Constituição da República Federativa do Brasil. Brasília: Senado Federal, 1988. Disponível em: <http://www.planalto.gov.br/ ccivil_03/Constituicao/Constituicao.htm>. Acesso em: 25 maio 2015.

BRASIL. Lei n. 9.099 de 26 de janeiro de 1995. Dispõe sobre os Juizados Especiais Cíveis e Criminais e dá outras providências. Brasília, DF, 1995. Disponível em: <https://www.planalto.gov.br/ccivil_03/LEIS/L9099. $\mathrm{htm}>$. Acesso em: maio 2015.

BRASIL. Resolução $n .196$ de 10 de outubro de 1996. Dispõe sobre as diretrizes e normas regulamentadoras de pesquisas envolvendo seres humanos. Conselho Nacional de Saúde, Brasília, DF, 10 de out. de 1996. Disponível em: <http://conselho.saude.gov.br/web_comissoes/conep/ aquivos/resolucoes/23_out_versao_final_196_ENCEP2012.pdf >. Acesso em: 15 maio 2015.

BRASIL. Lei n. 11.340 de 7 de agosto de 2006. Cria mecanismos para coibir a violência doméstica e familiar contra a mulher, nos termos do $\S$ $8^{\circ}$ do art. 226 da Constituição Federal, da Convenção sobre a Eliminação de Todas as Formas de Discriminação contra as Mulheres. Disponível em: <http://www.planalto.gov.br/ccivil_03/_ato2004-2006/2006/lei/ 111340.htm>. Acesso em: 5 maio 2014. 
INSTITUTO BRASILEIRO DE GEOGRAFIA E ESTATÍSTICA (IBGE). Características Étnico-Raciais da População: um estudo das categorias de classificação de cor ou raça 2008. Rio de Janeiro, 2011. Disponível em: <http://www.letraviva.net/arquivos/brasil-africa/Caracteristicas _ Etnico-raciais_da_Populacao_IBGE.pdf >. Acesso em: 26 maio 2015.

LEÃO, M. R. Relatório final do programa institucional de bolsistas de iniciação científica 2010-2011. Salvador, 2011. Mimeo.

PASINATO, W. Estudo de caso: sobre os juizados de violência doméstica e familiar contra a mulher e a rede de serviços para atendimento de mulheres em situação de violência em Cuiabá, Mato Grosso: relatório final. São Paulo, 2009. Disponível em: <http://www.observe.ufba.br/ ARQ/estudodecaso.pdf>. Acesso em: 26 de maio 2015.

SAFFIOTI, H. I. B. Já se mete a colher em briga de marido e mulher. São Paulo Perspec., São Paulo, v.13, n. 4, p. 82-91, abr., 1999.

SAFFIOTI, H. I. B.; ALMEIDA, S. S. de. Violência de gênero: poder e impotência. Rio de Janeiro: Revinter, 1995.

SARDENBERG, C.; GOMES, M.; TAVARES, M. A aplicação da Lei Maria da Penha em foco. Salvador: NEIM/UFBA, 2010.

SCOTT, J. Gênero: uma categoria útil de análise histórica. Educação \& Realidade, v. 20, n. 2, jul./dez., p. 71-99, 1995.

SOARES, J. E. Relatório final do programa institucional de bolsistas de iniciação científica 2010-2011. Salvador, 2011.

SILVA, E. L. da; LACERDA, S. O. de; TAVARES, M. S.. Denunciei, e agora? Fragmentos de conversas com mulheres em situação de violência. In: ENCONTRO DE PESQUISADORES EM SERVIÇO SOCIAL, 13. Juiz de Fora, 2012. Anais... Juiz de Fora, MG, 2012.

TAVARES, M. Para o monitoramento da Lei Maria da Penha. In: CONGRESSO BRASILEIRO DE ASSISTENTES SOCIAIS, 12., 2010, Brasília. Anais eletrônicos... Brasília, DF: CFESS: Observe, 2010. CD-ROM.

TAVARES, M.; SARDENBERG, C. Monitorando a aplicação da Lei Maria da Penha em Delegacias Especializadas de Atendimento à Mulher em Salvador/BA. In: QUADROS, M. T.; ALBERNAZ, L. S. F. (Org.). Gênero e violência no Nordeste e no meio rural. Recife: UFPE, [20--]. (Família e Gênero; $\mathrm{n}^{\circ}$ 16) (no prelo).

TAVARES, M.; SARDENBERG, C.; GOMES, M. O acesso à justiça no Brasil das mulheres em situação de violência. In: CONGRESSO BRASILEIRO DE SOCIOLOGIA, 15., Curitiba, 2011. Anais... Curitiba: 2011. 


\title{
SISTEMATIZAÇÃO DE DADOS DA PRODUÇÃO DE SERVIÇOS DE ATENÇÃO À MULHERES EM SITUAÇÃO DE VIOLENNCIA proposta de um grupo de trabalho
}

\author{
Cândida Ribeiro Santos \\ Maria Eunice Kalil \\ Suely Maria Costa Lôbo
}

\section{Introdução}

Cada vez mais, a informação vem sendo reconhecida como ferramenta fundamental para o planejamento e execução de políticas públicas. Seu uso pode orientar a definição de intervenções e investimentos e permitir acompanhar o desenvolvimento e resultado de ações.

Ao caracterizar a "informação como poder", a Agência Nacional de Vigilância Sanitária (Anvisa) (ANVISA, 2008) ${ }^{1}$ men- 
ciona que informar é reduzir as incertezas sobre fatos e coisas. Os gestores se afastam dessas incertezas através da avaliação, processo técnico-administrativo destinado à tomada de decisão, no qual estão envolvidos os momentos de medir, comparar e emitir juízo de valor. Nesse exercício, são pensadas questões como: o que fazer? Como fazer? Quanto fazer? Quando fazer? Com o que fazer? Como fazer acontecer? (ANVISA, 2008)

Produto do tratamento, do processamento, da análise ou da interpretação posterior dos dados, ${ }^{2}$ a informação é utilizada mais usualmente em forma de indicadores. O indicador é uma variável, característica ou atributo que é capaz de sintetizar, representar ou dar maior significado ao que se quer avaliar. (ANVISA, 2008)

Para a construção de indicadores, é ideal a existência de sistemas de informação, definidos como conjuntos de procedimentos utilizados que, quando executados, oferecem informação de suporte à organização. (ANVISA, 2008) Nesses sistemas, os bancos de dados apresentam-se como as ferramentas mais utilizadas.

No caso específico da violência contra a mulher, as autoridades políticas e gestores/as, de um modo geral, que lidam com esse problema no Brasil encontram grande dificuldade para utilizar a informação como subsídio para o planejamento e execução de políticas públicas direcionadas ao seu enfrentamento. A inexistência de sistemas de informações destinados à criação de indicadores capazes de mensurar o fenômeno e monitorar as políticas apresenta-se como uma das barreiras para o avanço no combate ao fenômeno, especialmente considerando que as próprias características da violência de gênero, com as dificuldades de explicitação, exposição e publicação que lhes são peculiares, já tornam complicada sua mensuração.

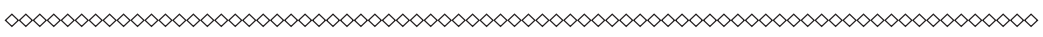
2 Elementos em estado bruto. (ANVISA, 2008) 
É verdade que parte da violência contra mulheres, aquela que se traduz em morte, aparece no Sistema de Informação de Mortalidade (SIM) do Departamento de Informática do Sistema Único de Saúde (Datasus/Ministério da Saúde). Esse sistema, cujo instrumento de coleta de dados é a Declaração de Óbito (DO), permite construir indicadores que dão ideia do risco de morrer por determinada situação, doença ou agravo, o que inclui o risco de mulheres morrerem de causas violentas. É verdade também que o Sistema de Informações sobre Internações Hospitalares (SIH), do Ministério da Saúde, permite saber das internações por tipo de causa, o que possibilita conhecer outro aspecto parcial da situação da violência contra mulheres.

Nos últimos anos, a violência doméstica, sexual e/ou outras violências passaram a fazer parte da lista de agravos de notificação compulsória do Ministério da Saúde - Sistema de Informação de Agravos de Notificação (Sinan) -, constituindo-se em outra fonte de informação sobre o atendimento, no setor saúde, de mulheres em situação de violência. Esses sistemas permitem conhecer partes do mosaico que é a situação da violência contra mulheres.

No estado da Bahia, como no restante do país, não há um sistema de informação geral sobre o problema. Da mesma maneira, grande parte dos serviços de atendimento a mulheres em situação de violência que funciona em seu território não possui banco que organize, disponibilize e sistematize os dados registrados em seu processo cotidiano de trabalho. Além disso, não há uniformidade na coleta da informação, já que cada serviço categoriza e trabalha os dados de acordo com a sua necessidade, inexistindo uma linha pré-determinada para ser seguida. Essa situação está documentada no "Cadernos do Observe Número 1", resultado de pesquisa realizada pelo Observatório pela Aplicação da Lei Maria da Penha (Observe/2010). Um dos mais importantes desafios para se realizar um acompanhamento acerca da aplicabilidade da Lei 
Maria da Penha, a partir dos serviços pesquisados em Salvador/ BA - Delegacias Especializadas de Atendimento à Mulher (DEAMs) e Vara de Violência Doméstica e Familiar -, é a ausência de um banco de dados sistematizado e unificado nesses equipamentos.

Todavia, é fato a existência de registros dos atendimentos nas instituições que recebem essas mulheres. No preenchimento dos formulários de atendimento dos serviços são registrados dados relativos às características do perfil socioeconômico das usuárias, do fato ocorrido, tipificação da violência, entre outras questões.

A existência desses registros motivou a criação de um Grupo de Trabalho Informação, com a tarefa de compartilhar, consolidar, analisar e construir informações a partir desses dados existentes, de modo que permita identificar variáveis comuns e caminhos para a consolidação regular de dados de violência contra a mulher em Salvador e Região Metropolitana de Salvador (RMS), dando visibilidade a outras partes do mosaico local do fenômeno.

Nessa perspectiva, o presente artigo tem a finalidade de apresentar e discutir a proposta desse grupo de trabalho, discorrendo, inicialmente, sobre sua constituição, objetivos, atividades realizadas e primeiros passos em direção à construção de indicadores sobre o problema. Em seguida, são discutidos os limites e desafios encontrados pelo referido grupo para a sistematização de dados de violência contra a mulher nos serviços de atendimento.

\section{O Grupo de Trabalho Informação}

O Grupo de Trabalho Informação é parte da estratégia de funcionamento do Grupo de Trabalho para Articulação da Rede de Atenção a Mulheres em Situação de Violência de Salvador e RMS - GT da Rede ${ }^{3}$ e instrumento de fortalecimento da própria rede de

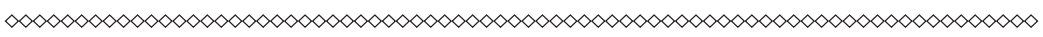

3 Formado por organizações da sociedade civil, organismos governamentais e serviços de atendimento, o GT da Rede tem quase 14 anos de atuação no objetivo de fortalecer a articulação 
atenção. Um dos subgrupos ${ }^{4}$ dessa articulação maior, o grupo de trabalho aqui em foco, foi planejado e concebido desde 2007, mas só tornado realidade no ano de 2010.

\section{Proposta}

A função básica do GT Informação é trabalhar os dados gerados nos serviços da rede de atendimento a mulheres em situação de violência em Salvador/Bahia e região metropolitana, de modo a contribuir para a visibilidade e compreensão da violência sofrida pelas mulheres e para o planejamento de ações de enfrentamento do problema, tanto por parte dos governos e serviços como por parte da população. As informações e indicadores produzidos devem possibilitar o melhor conhecimento do perfil das mulheres que buscam serviços e o acompanhamento da atenção oferecida a essas usuárias, além da composição do mosaico que é o retrato da situação do fenômeno da violência em Salvador e região metropolitana.

Enquanto objetivos específicos, o grupo se propõe a fazer o mapeamento estatístico dos diversos tipos de atendimento dos serviços que compõem a rede de atenção a mulheres em situação de violência em Salvador e RMS; organizar e analisar os dados produzidos pelos serviços, gerando informações que contribuam para o acompanhamento das ações de atenção a essas mulheres; compartilhar e discutir as informações consolidadas no e com o GT da Rede. da atenção integral) a mulheres em situação de violência, contribuindo para o enfrentamento desse problema na cidade de Salvador e sua região metropolitana.

4 Em 2007, quando se desenhou essa estratégia de funcionamento, o GT da Rede constituiu oito subgrupos que, com focos específicos, trabalham articuladamente, sendo eles: Formalização da Rede, Lei Maria da Penha, Monitoramento, Educação continuada para a Rede, Fluxos e Procedimentos, Saúde mental, Articulação da Sociedade Civil e Informação. Atualmente, mantém-se o subgrupo Informação, busca-se reorganizar o subgrupo Lei Maria da Penha e há o propósito de constituir um subgrupo de comunicação. 
Além desses objetivos, pretende-se estimular a utilização das informações produzidas pelos serviços para planejamento e monitoramento da atenção a mulheres nessa situação; organizar e analisar a participação da violência contra mulheres no panorama geral das violências e acidentes do estado da Bahia, integrando o grupo de trabalho de violência contra a mulher do Observatório de Violências e Acidentes do Estado da Bahia; ${ }^{5}$ e propor, montar e monitorar o desempenho de indicadores de acompanhamento da atenção às mulheres em situação de violência.

O SubGT Informação é formado por 11 serviços de atendimento à mulher em situação de violência que funcionam na capital e fazem parte do GT da Rede, sendo eles: as duas DEAMs - que funcionam nos bairros de Brotas e Periperi -; o Instituto de Perinatologia da Bahia (Iperba); as duas sedes do Projeto Viver Serviço de Atenção a Pessoas em Situação de Violência Sexual, que funcionam no prédio do Instituto Médico Legal da Bahia e no prédio da DEAM de Periperi; o Centro de Referência Loreta Valadares; a Casa de Acolhimento; o Centro de Referência Maria Felipa; ${ }^{6}$ a $1^{\text {a }}$ Vara de Violência Doméstica e Familiar contra a Mulher; o Grupo de Atuação Especial em Defesa da Mulher (Gedem); e o Núcleo Especializado na Defesa da Mulher da Defensoria Pública (Nudem).

As pessoas indicadas pelos serviços são aquelas que já lidam com a estatística de atendimento e passariam a participar do processo de compartilhamento e consolidação de dados e difusão de informações. Participam ainda outras pessoas do GT da Rede que se ocupam e/ou se interessam pela questão da informação no sen-

$\infty<\infty<\infty<\infty<\infty<\infty<\infty<\infty<\infty<\infty<\infty<\infty<\infty<\infty<\infty<\infty<\infty<\infty<\infty<\infty<\infty<\infty<\infty<\infty<\infty<\infty<\infty<\infty<$

5 Criado pelo Governo do Estado da Bahia em dezembro de 2009 (Decreto n. 11.897/2009), com a finalidade de registrar, sistematizar e disponibilizar dados estatísticos acerca das violências e acidentes ocorridos no estado. (BRAHIA, 2009, 2011)

6 Serviço especializado no atendimento de mulheres militares e esposas/companheiras/ familiares de militares em diversas circunstâncias, inclusive aquelas relacionadas com a vivência de violência por parte de policiais militares. 
tido estatístico e, no caso, no sentido da produção e uso de estatísticas de serviços de atenção.

Na dinâmica do grupo, o conteúdo e os produtos do seu trabalho são definidos coletivamente, em reuniões periódicas regulares. Além disso, tais produtos são discutidos e validados no GT da Rede antes de maior difusão.

\section{Caminho percorrido: pensando em indicadores de violência contra a mulher}

O Grupo Dinamizador ${ }^{7}$ do GT da Rede, antes mesmo do GT Informação constituir-se, propôs aos serviços, no final do ano de 2009, que preenchessem quadros, elaborados por componentes desse mesmo grupo, buscando ver que dados e informações eram possíveis de se obter a partir dos registros existentes. Nesses quadros, pretendia-se trabalhar: dados relativos ao número de atendimentos realizados e de mulheres atendidas por idade, por cor e por tipo de violência sofrida; sua relação com o/a agressor/a; o número de encaminhamentos feitos entre os serviços; entre outros dados. ${ }^{8}$

Apenas três serviços responderam ao desafio, que, naquela ocasião, ainda se começava a discutir, sem prosseguimento. Com a constituição do grupo, pensou-se que a primeira coisa a fazer seria o levantamento sistematizado dos procedimentos para registro de atendimentos e o uso que se faz desses registros em cada serviço, com uma atualização do preenchimento dos quadros propostos, em 2009.

A partir daí foi solicitado aos serviços os dados existentes do ano de 2009, para identificar as variáveis possíveis de serem tra-

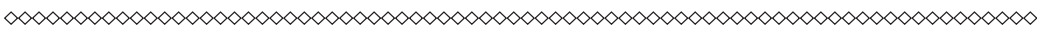

7 Pequeno grupo de pessoas responsáveis pela mobilização do GT.

8 Relativos às especificidades dos atendimentos de alguns serviços, como as DEAMs, Vara de Violência Doméstica e Familiar contra a Mulher e o Iperba. 
balhadas pelo grupo. Alguns serviços disponibilizaram seus dados do período solicitado, enquanto outros serviços forneceram também os dados existentes até julho de 2010.

A análise dos tipos de dados existentes nessas instituições mostrou que era possível construir e usar, como indicadores, pelo menos o número de mulheres atendidas (total e por faixa etária) e o número de atendimentos realizados. Contudo, percebeu-se que as diferentes formas de registro de cada serviço, em consonância com a especificidade de sua atividade, impossibilitavam a unidade do indicador. Esse momento também coincidiu com o desmonte da equipe psicossocial da $1^{\text {a }}$ Vara de Violência Doméstica e Familiar do Estado da Bahia, que possuía um banco de dados próprio, separado das informações necessárias para alimentar o sistema do Tribunal de Justiça.

As dificuldades e as diferenças e peculiaridades de cada serviço contribuíram para que o grupo do GT Informação avançasse e repensasse quais indicadores poderiam ser construídos. A partir do início de 2012, o GT definiu cinco linhas de trabalho:

1. Acompanhamento da morbimortalidade de mulheres por violências e acidentes nos grandes sistemas de informação da saúde:

1.1 Acompanhamento da mortalidade de mulheres residentes em Salvador e sua região metropolitana ${ }^{9}$ por violências e acidentes, com base dos registros do Sistema de Informações de Mortalidade (SIS), acessado através das páginas eletrônicas da Diretoria de Informações de Saúde (DIS), da Secretaria de Saúde do Estado da Bahia (Sesab). ${ }^{10}$ Nessa linha, em que o GT é parte

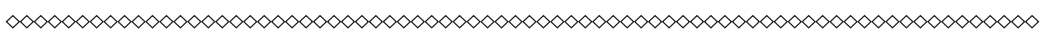

90 grupo de trabalho faz parte do GT da Rede de Atenção a Mulheres em Situação de Violência de Salvador e Região Metropolitana. Embora a participação de serviços dos outros municípios da RMS ainda não esteja consolidada, esse é um esforço a ser desenvolvido.

10 acesso através das páginas da DIS/SESAB permite trabalhar com dados mais atualizados que aqueles publicados nas páginas do Datasus/Ministério da Saúde. 
também do Subgrupo de Violência contra Mulheres do Observatório de Violência do Estado da Bahia, pretende-se elaborar e desenvolver um projeto de investigação das mortes de mulheres por homicídio, ${ }^{11}$ no sentido de melhorar o conhecimento sobre as circunstâncias relacionadas a esses homicídios, especialmente no que tange à autoria da agressão;

1.2 Acompanhamento da internação de mulheres residentes em Salvador e sua região metropolitana por acidentes e violências com base nos registros do SIH, acessado através das páginas eletrônicas da DIS, da Sesab;

1.3 Acompanhamento da notificação de violência doméstica e familiar e outras violências pelo Sinan, para mulheres residentes em Salvador e RMS, também acessado através das páginas da DIS/Sesab;

2. Consolidação e análise dos registros de produção mensal dos serviços de atenção a mulheres em situação de violência em Salvador.

3. Monitoramento da violência contra mulheres publicado nos jornais diários de Salvador e nos resultados de demanda ao Alerta Google para "violência contra a mulher". ${ }^{12}$

110 termo "investigação" aqui utilizado tem o sentido de investigação epidemiológica, como se investigam o óbito materno ou o óbito de menores de 1 ano, e não o sentido de investigação policial. Nessa investigação epidemiológica, é possível que sejam necessárias visitas às casas das vítimas para obtenção de informações sobre circunstâncias dos óbitos, mas, geralmente, a análise de laudos e prontuários do Instituto Médico Legal Nina Rodrigues (IMLNR) e dos hospitais é suficiente.

12 Este é um projeto desenvolvido pela Secretaria Executiva do Observatório de Violências e Acidentes em conjunto com a Diretoria de Vigilância e Atenção à Saúde do Trabalhador (Divast), da Sesab, que tem como um de seus resultados a possibilidade de indicar correções/ complementações para o Sistema de Informações de Mortalidade a partir de identificação de circunstâncias relacionadas a mortes violentas e, porventura, não constantes ainda naquele sistema. 
4. Proposição, elaboração e acompanhamento de indicadores da situação e da atenção (incluindo acesso à justiça) a mulheres em situação de violência:

4.1 Mortalidade de mulheres por homicídios, suicídios, acidentes de transporte e outros acidentes;

4.2 Internação de mulheres por agressões e tentativas de suicídio;

4.3 Notificação de violência contra mulheres no Sinan;

4.4 Número de mulheres (novas) atendidas pelos serviços/ número de atendimentos realizados pelos serviços;

4.5 Número de mulheres (novas) atendidas/número estimado de mulheres em situação de violência. Este deve ser um indicador da distância entre a oferta e a necessidade de serviços de atenção, entendendo como necessidade a existência de mulheres em situação de violência. Essa é a maior novidade - e risco - da proposição atual do GT, porque pretende incorporar a informação produzida por pesquisas de base populacional que trazem indicações e projeções sobre a incidência de violência contra mulheres. Será preciso levantar essas pesquisas e eleger ou construir uma estimativa da violência contra mulheres na população e no tempo e, ainda, construir a fórmula que permitirá encontrar o indicador.

4.6 Número de processos enquadrados na Lei Maria da Penha/número de mulheres (novas) atendidas;

4.7 Número de processos julgados/número de processos instaurados;

4.8 Número de medidas protetivas solicitadas/número de mulheres que prestaram queixa;

4.9 Outros indicadores a serem definidos oportunamente. 
5. Difusão e estímulo ao uso da informação:

5.1 Organização e publicação de tabelas e gráficos sobre a situação da violência nas páginas eletrônicas dos organismos de políticas para mulheres, de cada um dos serviços e do Observatório de Violências e Acidentes do Estado da Bahia;

5.2 Elaboração e difusão de informes semestrais de situação e de atendimento;

5.3 Elaboração e difusão de boletim anual sobre a situação da violência e sobre a atenção na rede;

5.4 Proposição de parâmetros para avaliação da política estadual e municipais de atenção a mulheres em situação de violência.

\section{Sistematização dos dados de violência contra a mulher: limites e desafios}

O GT Informação identifica algumas dificuldades para a organização dos dados produzidos nos serviços e a sua possível articulação à dinâmica de atendimento que acontece entre essas instituições. $\mathrm{O}$ primeiro deles se constitui na ausência de uma estrutura humana e física nos serviços que proporcionam condições aos/às seus/as funcionários/as para trabalhar na sistematização de dados.

A constatação do Grupo confirma o achado de um estudo realizado na área. Em trabalho intitulado "Passando a limpo: notas sobre um trabalho de campo do Observe nas DEAMs e na Vara de Violência Doméstica e Familiar contra a Mulher de Salvador/Ba”, Cândida Ribeiro Santos (2010, p. 2-4), em pesquisa realizada pelo Observe, ${ }^{13}$ verificou que:

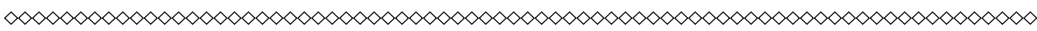

13 Projeto com o objetivo de monitorar e acompanhar o processo de implementação e aplicação

da Lei Maria da Penha no território brasileiro. Constitui-se em Consórcio formado por núcleos 
[...] havia, pelo menos, dois entraves para a realização de sistematização de dados nesses serviços, - o número pequeno de funcionárias (os) e desconhecimento da importância da pesquisa do Observe, que traduz a falta de capacitação do pessoal.

O Relatório Preliminar do Observatório, Monitoramento da Lei Maria da Penha, resultado de etapa anterior da citada pesquisa, já havia constatado que o número insuficiente de funcionários e a falta de capacitação ainda podem estar interferindo na forma como os dados vêm sendo coletados e sistematizados. (GOMES, 2009) Dados relevantes não vêm sendo coletados, ou em virtude da grande demanda a ser atendida, ou, talvez, por não serem considerados importantes. Tal realidade está de acordo com resultados encontrados em estudos realizados em Delegacias da Mulher, que verificaram a inadequação de espaço, equipamento e pessoal à demanda existente, além de pessoal não capacitado, sobretudo para prestar atendimentos que envolvem questões referentes à violência com base no gênero. (PASINATO; SANTOS, 2008)

Outra questão que se impõe como obstáculo à organização e sistematização dos dados de violência contra a mulher nos serviços é a dificuldade de contratar pessoas especializadas em criação e manejo de banco de dados com sensibilidade de gênero para atender às demandas dessas instituições. Depoimentos nesse sentido foram dados em reunião do GT Informação. ${ }^{14}$

A ausência de bancos de dados nos serviços também funciona como limite para a sistematização dos seus registros de atendimentos, que, muitas vezes, nem se encontram informatizados. As representantes dos serviços sempre ressaltam a existência de

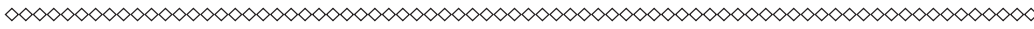
de pesquisa e organizações não governamentais de todo o país. A referida pesquisa tinha como objetivo aplicar formulários em todas as DEAMs e Juizados que funcionassem nas capitais dos 27 estados brasileiros. Para isso, foram selecionadas pesquisadoras locais, em cada uma das capitais, quando Cândida Ribeiro assumiu essa tarefa em Salvador, Bahia. Para maiores informações sobre o Projeto, essa e outras pesquisa do Observe, ver em <www.observe.ufba.br>.

Realizada na sede do Viver, no bairro do Garcia/Salvador, no dia 3 de novembro de 2010. 
dados valiosos, mas que se perdem porque a forma de registro não é informatizada. Ainda no que se refere a essa questão, relatou Santos (2010, p. 3):

Ao perguntar sobre a existência de sistematização dos dados, verifiquei a ausência de bancos ou até mesmo de planilhas e/ou arquivos disponíveis para a coleta. Apenas algumas iniciativas individuais e tímidas, como tabelas com as informações mais gerais do atendimento dos serviços.

$\mathrm{Na}$ realidade, os dados de alguns serviços constam em sistemas informatizados dos órgãos estaduais a que pertencem, como, por exemplo, os da Secretaria de Segurança Pública e Tribunal de Justiça, nos casos das DEAMs e Juizados Especiais de Violência Doméstica e Familiar, respectivamente. Todavia, nesses sistemas, os dados não se encontram organizados de forma que possam ser disponibilizados agilmente, além de, quase sempre, não serem coletados abarcando as características socioeconômicas e culturais que envolvem as mulheres em situação de violência e o problema de maneira geral.

Há ainda grande rigidez na estrutura e funcionamento dos sistemas de informação e bancos de dados existentes (Ministério Público e Tribunal de Justiça, por exemplo) que produzem relatórios pré-definidos, impossibilitando cruzamentos e análises mais livres de seus dados. Sem mencionar que esses sistemas são desenhados na lógica de produção e acompanhamento dos processos instaurados, visando à responsabilização e à reparação nas situações de violação de direitos e violência, e não o conhecimento do perfil das pessoas envolvidas nessas situações, que tem sido o foco predominante expresso nas discussões e demandas do GT Informações. O relato da representação do Gedem/MP no GT expressa bem os dois tipos de dificuldade: essa instituição tem problemas para sistematizar seus dados, de acordo com a demanda do GT Informação, por conta da formatação e maneira de funcio- 
namento do sistema do Tribunal de Justiça do Estado da Bahia. É explicitado que há possibilidade da ocorrência de repetição de dados, uma vez que as mulheres que são contabilizadas pelo Gedem podem estar fazendo parte dos dados da Vara de Violência, constante no mesmo sistema. Além disso, mencionou-se a rigidez desse sistema, que se expressa, sobretudo, pela impossibilidade de cruzamento dos seus dados.

Ainda no que se refere à repetição de dados, outra dificuldade encontrada para a construção de indicadores é o fato de que uma mulher é, com grande frequência, atendida em mais de um serviço, pertencente ou não à mesma Secretaria, que possui determinado sistema de informação. Isso acarreta duplicidade de registro dos atendimentos das usuárias que transitam pelos serviços, sobretudo na ocasião dos encaminhamentos realizados.

No que diz respeito à utilização do número de atendimentos como indicador da atenção prestada a mulheres em situação de violência, há ainda outro problema a ser enfrentado, que é o tipo de atividade que é contado como atendimento. Várias atividades realizadas pelos/as funcionários/as, como reuniões e palestras, além de ações de prevenção, não são consideradas e contabilizadas nos relatórios e sistemas de informação dos serviços, o que também é visto como uma limitação para a organização dos dados nessas instituições.

Para exemplificar, destaca-se a experiência da Casa de Acolhimento. Na citada reunião do grupo, sua funcionária mencionou sobre o diálogo que o serviço tem com a política de assistência, além da realização de atividades socioeducativas e adoção de cadernos que as mulheres acolhidas utilizam para falar sobre seu processo dentro da casa. Apesar da constatação de que todas essas atividades resultam na produção de dados, não há qualquer aproveitamento desse material no sentido de uma sistematização. 
Incluir esses tipos de atividades como atendimentos realizados representa um desafio especial, pois impõe uma discussão mais aprofundada sobre o que é e o que pode (ou precisa) ser a atenção a mulheres em situação de violência. Essa reflexão sobre modelos de atenção ultrapassa o escopo das tarefas do GT Informação, mas caberia a esse grupo provocar o GT da Rede nessa direção.

Outro aspecto identificado como dificuldade para o tratamento dos dados foi o amadurecimento e mudança nos registros de cada serviço. No Centro de Referência Loreta Valadares, por exemplo, na inauguração do serviço, havia uma dificuldade na tipificação da violência psicológica, e só dois anos depois, com a capacitação e experiência da equipe, passou-se a registrar esse dado de forma mais fidedigna. Ponderou-se também sobre as mudanças das informações registradas, já que o Centro, entre os anos de 2005 e 2010, trabalhou com um tipo de prontuário e, a partir de 2011, mudou o modelo e, consequentemente, a informação coletada.

Os descompassos nos níveis de organização de sistemas e formas de registros nos diferentes serviços também se apresentam como empecilhos para o trabalho proposto pelo GT Informação, na medida em que dificultam uma coleta e consequente sistematização mais uniforme entre essas instituições. Durante o trabalho inicial de coleta de dados nos serviços realizado pelo grupo, foi possível perceber que, enquanto alguns apresentavam seus dados em relatórios de papel, outros já estavam mais adiantados nesse sentido, possuindo até iniciativas de montagem de bancos de dados; enquanto um serviço explicita e separa o atendimento a casos novos, outro considera apenas os casos que foram atendidos em um ano específico. Tal realidade é consequência, principalmente, do fato de que os sistemas e formas de registro foram desenvolvidos individualmente por cada serviço, considerando suas especificidades, sem troca de experiência ou discussão com os demais serviços. 
De maneira geral, percebe-se uma lacuna no que se refere à sistematização de dados encontrada nos serviços de atendimento às mulheres em situação de violência que funcionam em Salvador e região metropolitana. Diante dessa realidade, o GT Informação se defronta com alguns desafios que precisam ser enfrentados como parte do trabalho para alcançar os objetivos propostos.

O primeiro deles é a necessidade de estimular a melhoria dos registros feitos nos serviços, através da elaboração de fichas de atendimento e relatórios que criem campos voltados para questões como características das mulheres, fatos ocorridos, entre outros. É preciso também encontrar meios de contribuir para que se viabilize a informatização dos processos de registro de atendimentos, com a consequente construção e manutenção de bancos de dados. Propõe-se que tais sistemas atendam prontamente às demandas externa de informação e conhecimento por parte de estudantes, pesquisadores/as e profissionais, como também àquelas relacionadas ao planejamento e administração de serviços e ao acompanhamento da situação de violência contra mulheres e do desenvolvimento de políticas de enfrentamento dessa situação.

Outro desafio é encontrar formas de identificar possíveis efeitos das políticas de enfrentamento da violência de gênero. Nesse processo, evitar a duplicidade de registro nas situações de mulheres encaminhadas de um serviço para outro tem sido um ponto fundamental nas discussões do GT por se constituir em tarefa complexa, porém imprescindível.

\section{Considerações finais}

A violência contra mulheres faz parte da estrutura da sociedade, e a luta pelo reconhecimento social desse fenômeno, como também pela sua eliminação, se incluiu no esforço para construção de realidades sociais mais justas e igualitárias. Aumentar a vi- 
sibilidade e a compreensão sobre as manifestações desse tipo de violência é uma forma de contribuir para a mobilização do Estado e da sociedade no sentido de avançar no seu processo de enfrentamento e, assim, progredir para uma mudança onde a diversidade entre os seres possa existir e se desenvolver em ambiente de respeito e igualdade de direitos.

O silêncio e a dissimulação, elementos geralmente presentes nas situações de violência contra mulheres, tornam particularmente difícil sua apreensão com base em sistemas de informação e de registros do cotidiano dos serviços de saúde, assistência social e educação, nos quais essa violência se expressa sob outros nomes e, escondida, grita por atenção todos os dias. Encontrar e propor formas de utilização consistente e coerente dos registros desses serviços para compor o quadro de compreensão do fenômeno e da intervenção sobre ele é o desafio e o risco a que se propõe o GT Informação.

A possibilidade de criar um indicador para o mapeamento da violência contra a mulher, mesmo deparando-se com registros tão diferenciados, não tem a pretensão de abarcar em números absolutos toda essa variedade. Saber os limites desses registros e poder focalizar essas diferenças é ter o objetivo de ampliar o olhar sobre essa temática, incluindo novas categorias de registro; é a ampliação do foco que modifica o modo de abordar esses índices. São várias perspectivas do mesmo problema: é a possibilidade de trazer outra perspectiva, iluminando outro aspecto do problema.

\section{Referências}

AGÊNCIA NACIONAL DE VIGILÂNCIA SANITÁRIA (ANVISA). Conceitos básicos para a construção de indicadores, capacitação no elenco norteador e indicadores do Sinavisa. Brasília, DF, 2008. Disponível em: $<\mathrm{http}$ ///portal.anvisa.gov.br/wps/wcm/connect/a6f4550047457a6b86 e4d63fbc4c6735/Conceitos+Basicos+para+Elaboracao+dos+Indicadores. ppt?MOD=AJPERES $>$. Acesso em: 2015. 
BAHIA. Decreto n. 11.897 de 17 de dezembro de 2009. Fica criado o Observatório de Violências e Acidentes do Estado da Bahia. Disponível em: <http://www1.saude.ba.gov.br/observatorio/admin/db/userfiles/ file/Legislacao/Portaria_627_Regimento_Interno_Observatorio.pdf>. Acesso em: 2015.

BAHIA. Observatório de violências e acidentes do Estado da Bahia. Salvador, [2011]. Disponível em: <http://www1.saude.ba.gov.br/ observatorio $/$ Pagina .aspx ?ms=9E2DFC56F0FF5768DFCEFF68E2 BE2429>. Acesso em: 2015.

GOMES, M. Q. C. Monitoramento da Lei Maria da Penha, 2009: relatório preliminar de pesquisa do Projeto Construção e Implementação do Observatório da Lei 11.340/2006 - Lei Maria da Penha. Salvador: [s.n.], 2009.

PASINATO, W.; SANTOS, C. M. Mapeamento das Delegacias da Mulher no Brasil. Campinas: Núcleo de Estudos de Gênero Pagu; UNICAMP, 2008.

SANTOS, C. Passando a limpo: notas sobre um trabalho de campo do OBSERVE nas DEAMs e na Vara de Violência Doméstica e Familiar contra a Mulher de Salvador / Ba. In: SEMINÁRIO INTERNACIONAL FAZENDO GÊNERO: DIÁSPORAS, DIVERSIDADES, DESLOCAMENTOS, 9., 2010, Florianópolis. Anais eletrônicos... Florianópolis: Universidade Federal de Santa Catarina, 2010.

SARDENBERG, C. M. B; TAVARES, M.; GOMES, M. A aplicação da Lei Maria da Penha em foco. Salvador: NEIM / UFBA, 2010. (Cadernos do Observe, 1).

SEMINÁRIO INTERNACIONAL FAZENDO GÊNERO: DIÁSPORAS, DIVERSIDADES, DESLOCAMENTOS, 9., 2010, Florianópolis. Anais eletrônicos... Florianópolis: Universidade Federal de Santa Catarina, 2010. Disponível em: $\langle$ http://www.fazendogenero.ufsc.br/9〉. Acesso em: 19 mar. 2012. 


\section{REDE DE ATENÇÃO À MULHER E À ADOLESCENTE EM SITUAÇÃO DE VIOLÊNCIA NO MUNICÍPIO DE JUAZEIRO/BA (RAMA/JUA) implantação, limites e desafios}

Jayce Layana Lopes Callou

Juliana Sampaio

\section{Introdução}

O presente artigo é referente a uma pesquisa realizada como Trabalho de Conclusão de Curso (TCC) sobre o processo de implantação de uma rede de serviços para a assistência à mulher em situação de violência no município de Juazeiro/BA, denominada Rede de Atenção à Mulher e Adolescente (Rama/Jua). Nesse intento, objetiva-se analisar o processo de implantação da Rama/Jua, elencando as principais dificuldades enfrentadas nesse processo, partindo de considerações teóricas acerca da proposta do trabalho em redes. (KISS; SCHRAIBER; D'OLIVEIRA, 2007) Tenta-se problematizar, assim, como se deu o processo de construção da rede; 
quais as principais dificuldades enfrentadas pelos atores envolvidos; quais os principais avanços que foram possíveis na constituição da Rama/Jua; e, por fim, quais articulações realmente existem entre os serviços que compõe a rede atualmente.

A relevância deste estudo se configura pela possibilidade de colocar em debate a formação de redes de serviços para o apoio e a assistência à mulher em situação de violência. A grande maioria das experiências publicadas encontra-se nas regiões Sul e Sudeste (NJAINE et al., 2006), sendo escassos estudos dessa natureza na região Nordeste, especificamente no contexto da Bahia, no qual a investigação foi realizada.

\section{A perspectiva do trabalho em redes de serviços na atenção à mulher em situação de violência}

Até meados da década de 1980, as iniciativas do governo brasileiro quanto à temática da violência contra mulheres se restringiam a encaminhamentos jurídicos, que nem sempre tinham fins satisfatórios para a mulher agredida. (CAMARGO; AQUINO, 2003) Nas décadas subsequentes até os dias atuais, muitos avanços em relação à temática da violência contra mulheres ocorreram com a implantação de políticas públicas e de conselhos de controle social; realizações de conferências nacionais e internacionais; e criação de novos serviços e instituições direcionados às mulheres em situação de violência. (D'OLIVEIRA; SCHRAIBER, 2006)

No que diz respeito aos novos serviços, destacaram-se: a criação de diferenciados serviços de saúde especializados na assistência de mulheres vítimas de violência sexual, a criação das Delegacias Especializadas de Atendimento à Mulher (DEAMs); Casas Abrigo; Instituto Médico Legal (IML); Serviços Sociais; Centros de Referências Multiprofissionais, dentre outros. (GROSSI; TAVARES; OLIVEIRA, 2008) Vale destacar, no entan- 
to, que a construção e consolidação desses serviços ocorreram de maneiras individualizadas, sem que se estabelecesse nenhuma relação entre eles.

Todo o debate público acerca dos direitos da mulher e do enfrentamento da violência de gênero vem desde a década de 1960, como consequência da luta do movimento feminista. Até então, todos os percalços da subordinação da mulher ao homem era remetido, exclusivamente, à esfera íntima das relações, não sendo alvo de discussões públicas. (SENA, 2004; VILLELA; LAGO, 2007) Aos poucos, o fenômeno da violência contra mulheres vem sendo abordado sob a perspectiva de gênero, propondo uma discussão mais ampla no âmbito da prevenção da violência e da assistência à mulher. (MARINHEIRO; VIEIRA; SOUZA, 2006)

Araújo (2002) destaca que a utilização da categoria gênero conjuntamente com a temática da violência contra a mulher não é arbitrária. Pelo contrário, ela está centrada nas relações de poder que são construídas e estabelecidas entre homens e mulheres. A categoria gênero é compreendida como uma construção sociocultural sobre o binômio: masculino e feminino, não sendo o sexo biológico o definidor central para a construção dos limites identitários entre homens e mulheres. (LAMAS, 2000)

Quanto ao Estado brasileiro, um grande avanço foi a criação da Secretaria Especial de Políticas para as mulheres SPM) em 2003, atrelada ao gabinete da Presidência da República, que atua com base na Política Nacional de Enfretamento da Violência contra as Mulheres, a qual foi estruturada pelo Plano Nacional de Políticas para as Mulheres (PNPM), que atualmente está em vigor na sua segunda versão. (PASINATO; SANTOS, 2008; SPM, 2007) Sabe-se que um dos eixos das políticas defendidas por parte da SPM consiste justamente no estabelecimento de diretrizes para a ampliação e sistematização da rede de assistência à mulher, reconhecendo a complexidade desse fenômeno. 
Nesse sentido, D’Oliveira e Schraiber (2006) destacam que diferentes estudos vêm sendo realizados, evidenciando que, para que o Estado e a sociedade civil atinjam seus objetivos quanto à erradicação da violência contra as mulheres, tornam-se necessárias ações integradas e articuladas com diferentes serviços. A construção de uma rede de assistência é defendida, uma vez que a demanda dessas mulheres vai além da denúncia da violência, sendo requisitados: assistência à moradia; creche/escola; direito civil; trabalho; assistência à saúde (incluindo atenção psicológica, ao uso abusivo de drogas/álcool e à saúde mental); dentre outras.

Nesse cenário, surge como prioridade a criação de redes integradas com vistas a apoiar mulheres em situação de violência, articulando serviços, instituições e ações municipais, estaduais e federais. (CARREIRA; PANDJIARJIAN, 2003)

Martins e Fontes (2004, p. 109), ao discutirem o conceito de redes, as compreendem como um "sistema complexo formado pela articulação institucional de ações envolvendo ao mesmo tempo governo, comunidades, organizações civis e instituições científicas." O conceito de redes, neste estudo, é compreendido como a integração dos diferentes serviços que dão suporte ao municípioEstado, no que diz respeito às mulheres em situação de violência, focando a "interconexão e interdependência de fluxo dos diferentes trabalhos.” (KISS; SCHRAIBER; D’OLIVEIRA, 2007, p. 486)

Aposta-se, assim, na perspectiva da gestão em redes que possuem como características centrais: a presença de um trabalho não hierarquizado, prevalecendo a noção de corresponsabilidade entre todos os atores envolvidos; a necessidade de mobilização permanente entre os membros, provocando um protagonismo constante; a realização de planejamentos, com definições de metas especificadas para cada serviço e ator envolvidos; e, por fim, é orientado por uma equipe interdisciplinar e pelo conceito teórico 
de integralidade da atenção. (CARREIRA; PANDJIARJIAN, 2003; SCHLITHLER, 2006)

A partir de tais compreensões e evidenciando que a construção de redes de serviços para atenção à mulher em situação de violência é um desafio em várias regiões do Brasil, o presente estudo pretendeu, ao analisar o processo de implantação e articulação da rede de proteção à mulher em situação de violência - Rama/Jua, contribuir com as produções teóricas acerca do trabalho em redes de serviços de enfrentamento da violência de gênero.

\section{Considerações teórico-metodológicas}

O estudo caracterizou-se como uma Pesquisa Qualitativa em Saúde, buscando a valorização dos sentidos e significados atribuídos pelos atores sociais envolvidos na pesquisa. (GIL; LICHT; SANTOS, 2006) Trata-se, ainda, de uma pesquisa de natureza exploratória, com a finalidade de conhecer o objeto de estudo quanto aos seus contextos e significados, tais quais se apresentam. (MINAYO, 2007)

Para efetivação do estudo, foi adotada a triangulação metodológica a partir da adoção de duas estratégias de coleta de dados, obtendo maior riqueza de informações. (MINAYO, 2007) A primeira técnica empregada foi a análise documental, sendo considerados documentos válidos: termo de pactuação entre as instituições, proposto pela Secretária de Saúde; apresentações de PowerPoint cedidas pelo Centro de Referência da Mulher do município acerca da Rama/Jua; fluxogramas, panfletos e cartilha informativa produzidos pelos serviços nas reuniões da rede, objetivando uma maior divulgação da Rama/Jua; e, por fim, fichas de notificação de violência cedidas pela Estratégia Saúde da Família (ESF).

A segunda técnica adotada foi a realização de entrevistas semidirigidas, objetivando uma maior flexibilidade por parte da 
pesquisadora em questionar os sujeitos envolvidos e, consequentemente, dos atores em expor seus sentidos e significados acerca da temática vigente. (MINAYO, 2007) Ao todo, foram realizadas 20 entrevistas semidirigidas com três grupos de atores. O primeiro foi formado por sujeitos que participaram do processo de implantação da Rama/Jua, representando alguns serviços e secretarias municipais que direta e indiretamente ofereciam ações direcionadas às mulheres em situação de violência - Secretaria de Educação; Secretaria de Saúde; Centro de Doenças Sexualmente Transmissíveis (DST/Aids); Pastoral da Mulher; Centro Integrado de Atendimento à Mulher (Ciam); Sentinela; casas abrigo para crianças; Conselho Tutelar; Complexo Policial Civil; Universidade Federal do Vale do São Francisco (Univasf). Para definição desses representantes, foram utilizadas as análises documentais, especificamente a cartilha informativa produzida por esses atores ao longo do processo de implantação. Contudo, nem todos os atores puderam ser contatados, por não estarem mais no município de Juazeiro/BA ou por se recusarem a participar da pesquisa, sendo possível realizar nove entrevistas, das 13 previstas.

O segundo grupo foi formado de coordenadores de instituições que devem compor a Rama/Jua: Secretaria de Saúde - através de hospital do município; da ESF; do Centro de DST/Aids -; Secretaria de Desenvolvimento e Igualdade Social (Sedis) - através do Centro Integrado de Atendimento à Mulher (Ciam), do Conselho Municipal de Defesa e Direito da Mulher (CMDDM), do Centro de Referência de Assistência Social (CRAS) e da Casa Abrigo -; Secretaria de Segurança Pública - através da DEAM, do Instituto Médico Legal (Polícia Técnica/IML), do Ministério Público, do $3^{\circ}$ Batalhão de Polícia Militar ( $\left.3^{\circ} \mathrm{BPMJ}\right)$ e do Complexo Policial Civil -; e instituições não governamentais, como a Pastoral da Mulher e clubes de mães. 
Salienta-se que não existiam documentos, até a elaboração da presente investigação, que delimitassem especificamente que serviços compõem a Rama/Jua. Nesse intento, buscou-se a delimitação, via a análise documental (especificamente de folhas de frequência, fluxograma, folhetos informativos e apresentação de PowerPoint), de circulação interna da secretaria que fazem referência à Rama/Jua, possuindo como critérios de delimitação da amostra a recusa dos sujeitos em participar do estudo ou aqueles pelos quais a pesquisadora não conseguiu contatar, sendo, então, realizadas oito entrevistas, das 14 previstas. As seis entrevistas não efetivadas justificam-se pela impossibilidade da pesquisadora contatar a pessoa responsável pela instituição e pela recusa do profissional responsável pelo serviço em participar do estudo.

O terceiro grupo foi formado por gestores municipais que estavam diretamente ligados às ações de assistência à mulher em situação de violência, dentre eles: um representante da Sedis, outro da Coordenação de Proteção e Cidadania e o coordenador de Prevenção à Violência e Cultura de Paz do Núcleo de Prevenção à violência e de Promoção à Saúde, sendo possível realizar as três entrevistas previstas.

A análise dos dados coletados, tanto nos documentos quanto nas entrevistas, foi realizada por meio da Análise de Conteúdo Temática (BARDIN, 1994), visando descobrir os núcleos de sentido presentes nos discursos dos atores envolvidos. Tais núcleos resultaram em três categorias de análises, que foram interpretadas de acordo com as considerações teórico-metodológicas vigentes nessa investigação.

Para atender às exigências éticas do Conselho Nacional de Saúde, previstas na Resolução 196/96 sobre pesquisas com seres humanos, foi solicitado aos serviços que compõem a Rama/Jua uma Carta de Anuência, e aos atores o Termo de Consentimento Livre Esclarecido (TCLE), no qual declararam estarem cientes dos 
objetivos e delineamentos da pesquisa. Foi garantido aos atores o sigilo das informações coletadas, com a utilização de nomes fictícios nas citações aqui presentes. Por fim, o projeto foi aprovado pelo comitê de ética do Hospital Universitário Lauro Wanderley (HULW), da Universidade Federal da Paraíba (UFPB).

\section{Resultados e discussões}

A partir da análise dos dados, foi possível observar que no município de Juazeiro/BA não há uma rede de atenção à mulher vítima de violência institucionalizada. Tal realidade é decorrente de muitas dificuldades, como a falta de compromisso dos atores envolvidos e de apoio institucional e político. Observa-se, ainda, o desconhecimento, por parte de alguns profissionais de serviços que desenvolvem ações junto a mulheres vítimas de violência no município e, consequentemente, da Rama/Jua e da própria política municipal, de assistência à mulher em situação de violência. Contudo, na prática existem serviços que mantêm certas articulações, mas sem uma comunicação efetiva, buscando individualmente prestar serviços nesse campo.

Para demonstrar tal realidade, os dados coletados neste estudo serão apresentados em três linhas argumentativas (seções): a primeira, "O processo de implantação: principais dificuldades e a não institucionalização da rede”, apresenta o processo de proposição da rede, assim como as dificuldades mais destacadas pelos profissionais e a consequente não institucionalização do processo. Em seguida, será apresentada "A falta de comunicação e a impossibilidade de uma atenção integral”, demonstrando a desarticulação existente entre os serviços, que, na realidade, é uma consequência do processo de não institucionalização, impossibilitando, assim, a atuação de uma rede de cuidado integral à mulher. E por fim, “Articulações existentes: uma possibilidade em potencial?”, na 
qual se evidencia que, apesar de todas as dificuldades, existe certa comunicação entre alguns serviços, que chamaremos de rede informal, já que até então não existem a institucionalização e formalização da rede.

\section{O processo de implantação: principais dificuldades e a não institucionalização da rede}

O município de Juazeiro/BA caracteriza-se como uma das principais cidades da região do sub-médio São Francisco, possuindo cerca de 243.896 habitantes. (IBGE, 2009) A região vem desenvolvendo políticas de apoio às mulheres em situação de violência por meio da criação de serviços na articulação entre setores governamentais e não governamentais.

A Rede de Atenção à Mulher em Situação de Violência do município de Juazeiro/BA vem sendo implantada desde 2006, por iniciativa da Secretaria Municipal de Saúde e movimento de mulheres na elaboração de um projeto financiado pelo Governo Federal. Dentre as ações propostas pelo município para a implantação da rede, os atores que participaram desse processo identificaram quatro: Ação 1 - sensibilização dos atores envolvidos,

principalmente quanto ao fenômeno da violência e à perspectiva do trabalho em redes; Ação 2 - capacitação das ESF acerca das fichas de notificação de violência preconizadas e regulamentadas pelo Ministério da Saúde na forma da Lei n. 10.778 (BRASIL, 2003); Ação 3 - elaboração de documentos para facilitar a comunicação na rede: cartilha informativa e fluxogramas do percurso das mulheres nos serviços; Ação 4 - tentativa de pactuação da gestão municipal de saúde com os serviços por meio de um documento oficial, contendo cláusulas que acordavam o comprometimento dos serviços com a rede. No entanto, essa última ação não pôde ser efetivada devido ao processo das eleições municipais paralisa- 
rem a articulação da rede em outubro de 2008, só sendo retomada no segundo semestre de 2009 , durante o procedimento de coleta de dados do presente estudo.

Nós fizemos um trabalho de sensibilização junto ao pessoal da ESF [...] fizemos trabalho de sensibilização também junto à Secretaria de Educação, com os gestores [...] fizemos mais uma reunião pra discutir a questão da notificação compulsória com o pessoal da área de saúde [...] Existia, parece, uma programação, um momento de sensibilização, depois um momento de pactuação, para efetivamente começar a rede. (Marcelo)

A partir da investigação do processo de implantação, observou-se que não existiram a institucionalização e consequente formalização da rede. Na verdade, as parcerias firmadas foram realizadas, exclusivamente, por pessoas consideradas, até então, comprometidas com o enfrentamento da violência contra a mulher na região.

Institucionalização é um conceito que vem sendo desenvolvido desde o século XIX pelas ciências política, sociológica e econômica. Para fins de aproximação com o trabalho em redes, utiliza-se a perspectiva sociológica justamente por considerar não apenas o caráter normativo e sistemático, mas o valorativo dos sujeitos envolvidos nos contextos institucionais. (VENTURA, 2005)

Assim, institucionalizar é normatizar, sistematizar e regular procedimentos em ambientes institucionais. Nessa direção, compreende-se neste artigo que a institucionalização de redes se opera na regulação dos serviços, na medida em que se torna comum a todos o modo de como exercitar esse "fazer em redes" que se materializa na normatização de instrumentos de referenciamento e na instrumentalização dos processos de avaliação e monitoramento. 
Com base nesses argumentos, compreende-se que a Rama/ Jua não foi institucionalizada, o que a tornou vulnerável a "n" dificuldades que impossibilitaram a sua real efetivação.

Como sustentação para essa afirmativa, alguns elementos podem ser evidenciados. O primeiro refere-se à própria inexistência da formalização da rede, tanto por parte da Secretaria de Saúde como dos serviços. A relevância dessa formalização se expressa na sua priorização no planejamento das ações para a implantação da rede, chegando até mesmo a ser iniciada, por meio de um termo de adesão dos serviços, a Rama/Jua. "Como eu 'tô' te falando, essa coisa desse documento [...] a ideia era exatamente que os gestores se comprometessem." (Juliana)

A formalização/institucionalização da rede permitiria, assim, que os coordenadores dos serviços e os gestores da Secretaria de Saúde se comprometessem oficialmente com a realização de atividades para consolidação da rede, garantindo recursos mínimos de trabalho e dando a legitimidade político/institucional que viabilizasse a sustentabilidade das ações da Rama/Jua.

Como consequência, a falta desse apoio institucional dos serviços se configurou, na fala dos/as entrevistados/as, como um grande entrave para o encaminhamento das ações da rede, pois não viabilizou os recursos necessários como transporte e telefone. "[Falta] o apoio institucional mesmo, uma politica efetiva, eu acho que não existiu. Por várias vezes eu vi J. reclamando que tinha que ligar do celular dela para as pessoas, pra confirmarem se iam ou não a reunião." (Marcelo)

Ainda no discurso dos/as entrevistados/as, foi possível identificar que a falta do apoio institucional foi percebida como ausência de priorização da política de atenção à mulher vítima de violência na agenda política do município. Esse cenário, por sua vez, causou desmobilização dos atores, que se sentiam sem legitimidade política para o encaminhamento do processo. 
Assim, a rede ficou dependente da iniciativa e do comprometimento individual dos atores, que, sem o referido apoio institucional, aos poucos foram se desmobilizando e se afastando do processo. "As pessoas não têm compromisso de continuar [...] 'inicia', mas depois vão abandonando, vão deixando." (Bárbara)

Como já pontuado, a formalização da rede, apesar de iniciada, não teve continuidade devido ao período eleitoral do município. Franco (2006) destaca os atravessamentos políticos/partidários como um dos grandes desafios atuais para o trabalho em redes. Nesse sentido, para os/as nove entrevistados/as que participaram do processo de implantação, como também para um dos três gestores, o principal entrave para a institucionalização da Rama/Jua foi a política partidária: "primeiro vem o cunho político [...] porque, assim, é a principal dificuldade hoje, porque as pessoas não fazem até porque sabem que amanhã elas vão estar fora." (João)

Nessa mesma direção, evidenciando a descontinuidade dos processos de trabalho ocasionada pelas mudanças de gestores, Machado e Porto (2003, p. 129) afirmam:

Uma dificuldade adicional para esse processo refere-se às disputas de poder nos diferentes níveis de governo, que, em função de mudanças na sua condução, vulnerabilizam as instituições pela descontinuidade das políticas setoriais/institucionais em curso e tendem a traçar ações identificadas com o gestor de plantão.

No caso da Rama/Jua, a mudança de gestores (prefeito e secretário de Saúde) acarretou um período de paralisação das articulações da rede, as quais só foram retomadas oito meses após o processo eleitoral.

Retomando os argumentos para a sustentação da afirmativa sobre a não institucionalização da Rama/Jua, como segundo fator que a evidencia, pode ser apontada a inexistência de instrumentos 
únicos de encaminhamentos. Dos oito serviços contatados, apenas dois afirmaram ter instrumentalização escrita para possíveis encaminhamentos às mulheres aos serviços da rede. Os outros seis afirmaram "encaminhar" verbalmente.

Evidencia-se, com isso, tanto a fragilidade da referência quanto da contrarreferência, que, por sua vez, trazem algumas consequências. A primeira refere-se à falta de proteção da mulher, que finda por peregrinar pelos serviços em busca de acolhimento. A segunda refere-se à dificuldade do acompanhamento longitudinal do caso, que impossibilita a responsabilização pelo mesmo. E a terceira consequência refere-se à impossibilidade de articulação das ações desenvolvidas pelos serviços que possam promover a integralidade e resolutividade da atenção.

Assim, evidencia-se a carência de uma das principais características da institucionalização, que é a normatização dos processos institucionais. (VENTURA, 2005)

Por fim, como terceiro fator que demonstra a não institucionalização da rede de atenção à mulher em situação de violência em Juazeiro/BA, foi possível evidenciar a inexistência de processos sistemáticos de monitoramento e avaliação das ações previstas no projeto de implantação da Rama/Jua. Destaca-se que oito dos/as nove entrevistados/as que participaram da implantação afirmaram existir "avaliações" pontuais ao término de cada ação realizada.

A avaliação era dos momentos, no final de cada reunião. E havia uma avaliação assim, quando terminava os momentos, que a gente ia planejar os momentos seguintes, que eu sentava com $G$. [...] E aí a gente sentava e discutia. Discutia um pouco do que tinha acontecido, do que poderia ser melhorado. (Maria) 
Contudo, apesar dos/as entrevistados/as declararem a existência de avaliações, estas não se configuram como a institucionalização de um processo de monitoramento e avaliação, fundamental para a viabilização dos trabalhos em redes. Compreende-se que um processo de monitoramento e avaliação se diferencia de avaliações verbais pontuais em reuniões, pois, enquanto o segundo é apenas uma estratégia para o levantamento de opiniões não sistematizadas dos atores envolvidos - que pode ser, inclusive, uma fonte de dados para o monitoramento e a avaliação -, o primeiro requer instrumentos e técnicas específicas, como o estabelecimento de metas e de indicadores. Os processos de monitoramento e avaliação devem ter um caráter estratégico para a tomada de decisão, ocorrendo de forma interdisciplinar, contínua e multifacetada, com a coparticipação de todos os envolvidos no processo (HARTZ; CONTANDRIOPOULOS, 2004; SANTOS FILHO, 2007), o que não pode ser evidenciado no caso da Rama/Jua.

\section{A falta de comunicação e a impossibilidade de uma atenção integral}

Como consequência última da não institucionalização da Rama/Jua, foi possível observar, na totalidade dos discursos dos/ as profissionais entrevistados/as, uma desarticulação dos serviços que a compõem. E, nesse ponto, instala-se um paradoxo: afinal, como trabalhar na perspectiva de redes se na Rama/Jua inexiste uma comunicação efetiva intra e intersetorial, a qual promove o desconhecimento, por parte de alguns profissionais, sobre os serviços do município que prestam apoio à mulher vítima de violência, sobre a estrutura, objetivos e ações da Rama/Jua e a política de assistência à mulher em situação de violência no município?

Por isso, um dos principais elementos para a atuação em redes é justamente a comunicação. (FARAH, 2004) A fragilidade na co- 
municação entre os setores promove o desconhecimento de alguns profissionais sobre os serviços e ações disponíveis na rede que permitiriam a construção de um projeto de intervenção para o caso.

Se eu me deparasse com uma situação dessa, eu mandaria errado. Eu não sei, eu não sei como é que é a assistência. Se ela for, por exemplo, procurar a delegacia da mulher, eu não sei como é que está sendo, eu não sei como é que ela é tratada lá, eu não sei se ela é acolhida lá, eu não sei mesmo. (Íris)

Esse desconhecimento reflete na efetivação da rede de cuidado à mulher justamente porque os dispositivos de cuidados (serviços) não são operados pelos profissionais, tornando inviável a garantia da atenção integral à mulher em situação de violência.

A integralidade pressupõe uma rede complexa de serviços, com uma abordagem e intervenção interdisciplinar, intersetorial e interinstitucional, focando as diferentes dimensões do sujeito. (ANDRADE; FONSECA, 2008) O conceito em questão é recente no Brasil e seu uso ganhou destaque a partir da luta da Reforma Sanitária, sendo considerado, atualmente, como um dos grandes desafios da saúde pública.

A integralidade é percebida como um dos eixos norteadores das ações no enfrentamento da violência contra a mulher, na medida em que se configura como um sistema de cuidados com múltiplas dimensões, requerendo o reconhecimento dos serviços por parte dos atores envolvidos para a real efetivação desses sistemas de cuidados. (MANDÚ et al., 1999)

No caso do município de Juazeiro/BA não se trata meramente de um desconhecimento dos profissionais acerca dos serviços que dão assistência à mulher em situação de violência e, consequentemente, da Rama Jua, mas do desconhecimento da própria política de assis- 
tência à mulher, que explicita as garantias que devem ser asseguradas no atendimento à mulher em situação de violência de gênero.

Com isso, os profissionais não percebem o impacto de suas ações na rede de cuidados. "Quanto menos a gente vê, quanto menos a gente diagnosticar que ela sofre violência, melhor para a gente [...] [pois] como é que eu vou intervir?" (Íris). Eles também não percebem a diferença de qualidade que poderia ser alcançada se trabalhassem coletivamente por meio da "adoção de ações em diferentes áreas, de forma sistemática e continuada, garantindo acesso e qualificando a intervenção." (CAMARGO; AQUINO, 2003, p. 39)

Como consequência, de acordo com os/as profissionais entrevistados/as, as ações do município são pontuais. Com exceção da tentativa da implantação da Rama/Jua, a temática só é colocada em pauta em datas estratégicas e em campanhas do Governo Federal, como o dia 8 de março (Dia Internacional da Mulher) e a campanha dos 16 dias de ativismo pelo fim da violência contra as mulheres no Brasil, que ocorre em meados de novembro e dezembro.

Segundo os/as entrevistados/as, apenas nesses momentos,é colocada em pauta uma agenda de debates acerca da violência contra a mulher sob o viés da perspectiva da igualdade de gênero: "você vê que só quando chega o Dia Internacional da Mulher, alguma data que tem alguma relação com a violência contra mulher, é que reata alguma coisa, mas no dia a dia você não ouve falar." (Bárbara) Esse dado remarca a falta de priorização na agenda do município quanto à política de enfrentamento da violência de gênero anteriormente apontada.

Contudo, os esforços dispensados para a efetivação da Rama/ Jua geraram frutos no sentido de mobilizar alguns atores frente à causa. Salienta-se que o desconhecimento dos serviços da Rama/ Jua, assim como da política municipal de assistência à mulher em situação de violência, foi mais expressivo nos discursos dos re- 
presentantes dos serviços que não participaram diretamente do processo de implantação e das ações propostas pela Rama/Jua.

\section{Articulações existentes: uma possibilidade em potencial?}

Diante das reflexões tecidas quanto à falta de institucionalização da Rama/Jua, pode-se compreender que, mesmo diante dessa realidade, tem sido possível constituir certas articulações entre alguns serviços e atores estratégicos.

Essas articulações caracterizam-se por seu caráter informal justamente pela carência de legitimação político/institucional, que se reflete, inclusive, no não reconhecimento, por parte dos próprios atores, do pertencimento à Rama/Jua. Em nenhuma das entrevistas foi possível identificar algum relato de pertencimento à rede, nem mesmo nas entrevistas dos representantes das instituições mais ativas no processo de sua implantação. Esse dado tem repercussões na construção da identidade do grupo, que inviabiliza seu autorreconhecimento e legitimação, mesmo que interna.

De acordo com Caldas e Wood Junior (1997), o conceito de identidade vem sendo utilizado em contextos organizacionais/ institucionais, desde meados das décadas de 1980/1990, por meio de conceitos advindos da Psicologia social. Assim, entende-se que identidade institucional poderia ser a forma como a instituição percebe a si mesma, permitindo que as relações estabelecidas entre os atores tenham um real sentido para os mesmos e estejam integradas por objetivos comuns. A constituição de uma identidade permite ainda que os valores e posturas dos atores estejam coerentes com os contextos em que estejam inseridos.

Vale ainda destacar que as articulações tecidas nessa rede informal evidenciam a dificuldade do trabalho intersetorial, compreendido como fruto de inter-relações entre os serviços em um 
sistema "sem muros", como afirma Hartz e Contandriopoulos (2004). Foi possível observar que as parcerias e encaminhamentos que foram plausíveis de serem realizados aconteciam, na maioria das vezes, entre os serviços de uma mesma secretaria de governo; ou seja, entre os serviços da Secretaria de Saúde, ou entre os serviços da Secretária de Segurança Pública, ou entre os serviços da Secretaria de Desenvolvimento e Igualdade Social.

Contudo, algumas parcerias foram possíveis, assim como a realização de certas ações conjuntas. Em alguns casos, principalmente entre instituições que não foram tão afetadas com a troca de profissionais pelo processo eleitoral e que participaram mais ativamente do processo de implantação da Rama/Jua, determinadas articulações intersetoriais foram viabilizadas.

Nós temos parcerias na área da saúde com o Posto de Saúde aqui vizinho, então a gente procura 'vê' se tem preventivo, algum exame... Tem o Centro de DST/Aids que tem muito a questão das Doenças Sexualmente Transmissíveis [...] No reconhecimento de paternidade, pensão alimentícia, com a Universidade do Estado da Bahia, a gente tem uma parceria lá com o setor de práticas jurídicas [...] e temos uma parceria com o SENAC [Serviço Nacional de Aprendizagem Comercial] pra 'tá' desenvolvendo os cursos profissionalizantes. (Rose)

Assim, apesar das problemáticas elencadas, é possível perceber o início de um processo de articulação em redes de serviços no município de Juazeiro/BA, colocando em pauta uma problemática até então não emergente na região do submédio São Francisco.

Na verdade, a rede, ela [a Rama/Jua] foi sendo formada por aproximação. Uma coisa é você desenhar uma rede ideal, outra coisa é você construir uma rede possivel [...] De fato, a rede está em estruturação [...] Elas surgem des- 
sas aproximações possíveis [...] Então eu acho que como resultado final, você não deve dizer que não existe Rama/ Jua, mas que ela está em estruturação, e que o ideal não é agora o possível, devido às dificuldades. (Marcelo)

\section{Considerações finais}

Para a consolidação da Rama/Jua, há ainda um longo caminho a ser seguido. O resgate histórico de seu processo de implantação permite identificar seus entraves e potencialidades, sendo um importante instrumento de avaliação de processo para a tomada de decisão de gestores que se fizerem de fato comprometidos pelo enfrentamento à violência de gênero em Juazeiro/BA.

O presente estudo permite evidenciar a relevância do processo de institucionalização da Rama/Jua, demonstrando que, na medida em que existe o apoio institucional, as redes tornam-se mais sustentáveis e menos vulneráveis a possíveis dissociações, ocasionadas por diferentes acontecimentos e dificuldades ao longo do seu processo de consolidação.

Assim, aponta-se caminhos para a estruturação de uma efetiva rede de cuidados, o desenvolvimento de trabalhos voltados para a sensibilização acerca do trabalho em redes, tanto com os profissionais dos serviços, como com os gestores municipais. Essas sensibilizações poderão viabilizar uma maior apropriação dos atores da proposta da Rama/Jua, incentivando, assim, maior comprometimento dos serviços e das secretarias municipais com a atenção à mulher em situação de violência.

Defende-se, ainda, a necessidade de novos estudos, devido à escassez de produções teóricas sobre o tema no contexto da Bahia. Estudos que enfoquem o alcance das ações de atenção à mulher vítima de violência na região, tendo em vista que, apesar de não 
ter sido objetivo do presente estudo, foi possível constatar o desconhecimento da rede também por parte da comunidade local. A aposta em tais investimentos deve-se ao reconhecimento da complexidade e gravidade do fenômeno da violência contra a mulher, que tem impacto direto na qualidade de vida da população, sendo imprescindível seu enfrentamento para a construção de uma cidade mais saudável para todas e todos.

\section{Referências}

ANDRADE, C. J. M.; FONSECA, R. M. G. S. Considerações sobre violência doméstica, gênero e o trabalho das equipes de saúde da família. Rev. esc. enferm. USP, São Paulo, v. 42, n. 3, p. 591-595, 2008.

ARAÚJO, M. F. Violência e abuso sexual na família. Psicol. estud., Maringá, v. 7, n. 2, p. 3-11, 2002.

BARDIN, L. Análise de conteúdo. Lisboa: Edição 70, 1994.

BRASIL. Lei n. 10.778, de 24 de novembro de 2003. Estabelece a notificação compulsória, no território nacional, do caso de violência contra a mulher que for atendida em serviços de saúde públicos ou privados. Diário Oficial [da] República Federativa do Brasil, Brasília, DF, 25 nov. 2003.

BRASIL. Pacto nacional de enfrentamento à violência contra a mulher. Brasília: Secretaria Especial de Políticas para Mulheres, 2007.

CALDAS, M. P.; WOOD JUNIOR, T. Identidade Organizacional. Revista de administração de empresas, São Paulo, v. 37, n. 1, p 6-17, jan./mar., 1997.

CAMARGO, M.; AQUINO, S. Redes de Cidadania e parcerias enfrentamento a rota crítica. In: BRASIL. Programa de prevenção, assistência e combate à violência contra a mulher - plano nacional: diálogos sobre violência doméstica e de gênero: construindo políticas públicas. Brasília, DF: Secretaria Especial de Políticas para as Mulheres, 2003. p. 39-46.

CAMPOS, C. E. A. O desafio da integralidade segundo as perspectivas da vigilância da saúde e da saúde da família. Ciênc. saúde coletiva, Rio de Janeiro, v. 8, n. 2, p. 569-584, 2003. 
D'OLIVEIRA, A. F. P. L; SHRAIBER, L. B. (Coord.). Identificando possibilidades e limites do trabalho em rede para a redução da violência contra a mulher: estudo entre três capitais brasileiras. São Paulo: Ministério da Justiça, 2006.

CARREIRA, D.; PANDJIARJIAN, V. Vem pra roda! Vem pra rede! guia de apoio à construção de rede de serviços pra o enfrentamento da violência contra a mulher. São Paulo: Rede Mulher de Educação, 2003.

FARAH, M. F. S. Gênero e políticas públicas. Rev. Estudos feministas, Florianópolis, v. 12, n. 1, p.47-71, 2004.

FRANCO, T. B. As Redes na micropolítica do processo de trabalho em saúde. In: PINHEIRO, R.; MATTOS, R. A. de (Org.). Gestão em Redes: práticas de avaliação, formação e participação na saúde. Rio de Janeiro: CEPESC, 2006.

GIL, A. C.; LICHT, R. H. G.; SANTOS, B. R. M. Porque fazer pesquisa qualitativa em saúde. Cad. Saúde Pub., São Caetano do Sul, v. 1, n. 2, p. 5-19, 2006.

GROSSI, P. K.; TAVARES, F. A.; OLIVEIRA, S. B. de. A rede de proteção à mulher em situação de violência doméstica: avanços e desafios. Athenea Digitall, Barcelona, n. 14, p. 267-280, outono, 2008.

HARTZ, Z. M. A.; CONTANDRIOPOULOS, A. P. Integralidade da atenção e integração de serviços de saúde: desafios para avaliar a implantação de um "sistema sem muros”. Cad. Saúde Pública, Rio de Janeiro, v. 20, n. 2, p. 5331-5336, jan., 2004.

INSTITUTO BRASILEIRO DE GEOGRAFIA E ESTATÍSTICA (IBGE). Estimativas das populações residentes, em $1^{\circ}$ de julho de 2009, segundo os municípios. Rio de Janeiro, 2009. Disponível em: <http:// www.ibge.gov.br/home/estatistica/populacao/estimativa2009/ POP2009_DOU.pdf>. Acesso em: 16 out. 2009.

KISS, L. B.; SCHRAIBER, L. B.; D'OLIVEIRA, A. F. P. L. Possibilidades de uma rede intersetorial de atendimento a mulheres em situação de violência. Interface, Botucatu, v. 11, n. 23, p. 485-501, set./dez., 2007.

LAMAS, M. Gênero: os conflitos e desafios do novo paradigma. Proposta, n. 84/85, p. 12-25, 2000. 
MACHADO, J. M. H.; PORTO, M. F. S. P. Promoção da saúde e intersetorialidade: a experiência da vigilância em saúde do trabalhador na construção de redes. Epidemiol. Serv. Saúde, Brasília, DF, v. 12, n. 3, p. 121-130, set., 2003.

MANDÚ, E. N. T. et al. Atenção integral à saúde feminina: significados e implicações. Rev. Esc. Enf. USP, São Paulo, v. 33, n. 1, p. 31-8, mar., 1999.

MARINHEIRO, A. L. V.; VIEIRA, E. M.; SOUZA, L. Prevalência da violência contra mulher usuária de serviço de saúde. Rev. Saúde Pública, São Paulo, v. 40, n. 4, p. 604-10, ago., 2006.

MARTINS, P. H.; FONTES, B. Construindo o conceito de redes de vigilância em saúde. In: MARTINS, P. H.; FONTES, B. (Org.). Redes sociais e saúde: novas possibilidades teóricas. Recife: Editora Universitária da UFPE, 2004. p. 103-119.

MINAYO, M. C. S. O desafio do conhecimento: pesquisa qualitativa em saúde. 11.ed. São Paulo: Hucitec, 2007.

NJAINE, K.; et al. Redes de prevenção à violência: da utopia à ação. Ciênc. saúde coletiva, Rio de Janeiro, v. 11, n. 2, p. 429-438, 2006.

PASINATO, W. SANTOS, C. M. Acesso à justiça para mulheres em situação de violência: estudo comparativo das delegacias da mulher na América Latina (Brasil, Equador, Nicarágua, Peru). São Paulo: PAGU/ UNICAMP Núcleo de Estudos de Gênero Pagu, 2008.

SANTOS FILHO, S. B. Perspectivas da avaliação na Política Nacional de Humanização em Saúde: aspectos conceituais e metodológicos. Ciênc. saúde coletiva, Rio de Janeiro, v. 12, n. 4, p. 999-1010, jul./ago., 2007.

SENA, F. M. R. Mulheres em movimento: construção de relações de gênero na militância política das mulheres. 2004. 174f. Dissertação (Mestrado em Políticas Públicas e Sociedade) - Núcleo de Estudos e Pesquisas Sociais, Universidade Estadual do Ceará, Fortaleza, 2004.

SCHRAIBER, L. B. et al. Violência contra mulheres entre usuárias de serviços públicos de saúde da Grande São Paulo. Rev. Saúde Pública, São Paulo, v. 41, n. 3, p. 359-67, jul., 2007.

SCHLITHLER, C. Redes Intersetoriais de Desenvolvimento Comunitário. Artigos e Notas Técnicas - Instituto para o desenvolvimento do Investimento Social, São Paulo, 26 abr. p. 1-6, 2006. 
VENTURA, E. C. F. Dinâmica de institucionalização de práticas sociais: estudo da responsabilidade social no campo das organizações bancárias. 2005. 351 f. Tese (Doutorado em Administração) - Centro de Formação Acadêmica e Pesquisa, Fundação Getulio Vargas, São Paulo, 2005.

VILLELA, W. V.; LAGO, T. Conquistas e desafios no atendimento das mulheres que sofreram violência sexual. Cad. Saúde Pública, Rio de Janeiro, v. 23, n. 2, p. 471-475, fev., 2007. 


\title{
A VIOLENNCIA CONTRA A MULHER EM MACEIÓ o perfil dos agressores ${ }^{1}$
}

\author{
Andréa Pacheco de Mesquita
}

\section{Introdução}

A violência contra a mulher é um fenômeno, como diz Sardenberg (2011), ${ }^{2}$ extremamente "democrático", porque acontece em todas as classes sociais, em todas as gerações, em todas as raças e etnias, em todos os lugares. Ou seja, é um fenômeno que parte de uma lógica patriarcal e machista, colocando de um lado a mulher na condição de dominada e submissa, e de outro, o homem na condição de dominador e opressor. É um processo de disciplinamento de gênero, o qual ensina tanto para os homens quanto para as mulheres que a mulher é propriedade do homem

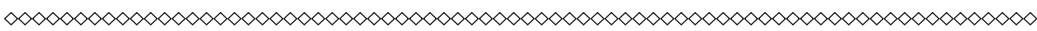

1 Texto apresentado no XVI Simpósio Baiano de Pesquisadoras/es sobre Mulheres e Relações de Gênero, que aconteceu em 2010, na cidade de Salvador/BA.

2 Texto baseado numa primeira versão apresentada como contribuição aos debates sobre o Projeto de Lei n. 19.137/2011, na Comissão da Mulher da Assembléia Legislativa da Bahia, em 24 de agosto de 2011. 
e tem de se submeter às suas vontades e aos seus processos disciplinadores (violência simbólica, física e sexual). Essa relação, até a criação da Lei Maria da Penha, ${ }^{3}$ era vista como uma questão do espaço doméstico e que não poderia receber nenhuma intervenção do Estado. No dito popular, reforçava a lógica de que "em briga de marido e mulher ninguém mete a colher”. A Lei n. 11.340, de 7 de agosto de 2006, foi fruto ${ }^{4}$ de várias lutas dos movimentos de mulheres que denunciavam o problema da violência contra a mulher, sob a bandeira de que o "pessoal é político", e ressaltavam a necessidade da formulação de políticas públicas e de uma intervenção por parte do Estado de forma direta, através de leis e políticas públicas que erradicassem esse tipo de violência baseada numa lógica patriarcal de poder e dominação masculina de um lado e na subordinação e opressão da mulher de outro. A lei propõe romper a ideia historicamente disseminada na sociedade de que o homem é o "dono"/ "chefe" da casa, dos filhos/as, da esposa e dos patrimônios. Assim, essa lei:

[...] cria mecanismos para coibir e prevenir a violência doméstica e familiar contra a mulher, nos termos do $\$ 8^{\circ}$ do art. 226 da Constituição Federal, da Convenção sobre a Eliminação de Todas as Formas de Violência contra a Mulher, da Convenção Interamericana para Prevenir, Punir e Erradicar a Violência contra a Mulher e de outros tratados internacionais ratificados pela República Federativa do Brasil; dispõe sobre a criação dos Juizados de Violência Doméstica e Familiar contra a Mulher; e estabelece

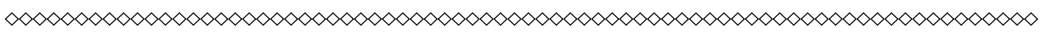

3 Essa lei teve o nome da farmacêutica cearense Maria da Penha, que sofreu dois atentados por seu marido e passou 20 anos lutando para que ele fosse condenado. Sem êxito, ela (junto a vários movimentos feministas e de mulheres de todo o país) recorre à Comissão Interamericana de Direitos Humanos da Organização dos Estados Americanos (OEA). Assim, o Brasil também foi condenado por neg'ligência e omissão à violência doméstica. Como punição, foi recomendado ao Brasil que criasse legislações para enfrentar esse tipo de violência. Diante desse fato de repercussão internacional, os movimentos e os parlamentares reuniram-se e elaboraram um anteprojeto para coibir a violência doméstica e familiar, que foi aprovado em 2006.

4 Apesar de compreender a importância dos movimentos de mulheres e feministas para a lei, é importante falar do próprio movimento do Estado, que vivenciou o processo de globalização que participava de conferências mundiais e pactos internacionais que reconheciam a violência contra a mulher como violação dos direitos humanos. Assim, não poderia cruzar os braços diante dos alarmantes índices de violência contra a mulher. 
medidas de assistência e proteção às mulheres em situação de violência doméstica e familiar (Art. $1^{\circ}$ ). (BRASIL, 2006)

A lei define o conceito de violência doméstica e familiar contra a mulher, de forma clara e objetiva, como "[...] qualquer ação ou omissão baseada no gênero que lhe cause morte, lesão, sofrimento físico, sexual ou psicológico e dano moral ou patrimonial." (BRASIL, 2006, art. 5)

Assim, ao passo que a lei propõe um conjunto de aparatos legais, jurídicos, políticos e educativos para coibir a violência doméstica, se faz necessário conhecer quem são as mulheres vítimas da violência e também quem são os agressores para que possa, a partir desses dados, conhecer e intervir de forma direta nessa realidade através de políticas públicas com um viés de gênero, ou seja, criar políticas públicas que interfiram diretamente na desigualdade entre homens e mulheres, rompendo assim a "ordem patriarcal de gênero" historicamente presente em nossa sociedade.

Falar sobre a violência requer entender a história da sociedade como uma história androcêntrica marcada fortemente pelo vetor do "arquétipo viril", como bem ensina Sarda (1987). Uma história dos homens e que tem como sujeito o homem branco, ocidental, rico e heterossexual, colocando à margem da história qualquer um que não se enquadre nesse modelo universal. A violência contra a mulher se configura como uma das formas mais agressivas do patriarcado (expressa no machismo), que é apoiada e consentida cotidianamente pela mídia (através das músicas, novelas, filmes, propagandas etc.), pela escola, pelas instituições religiosas, pelos partidos políticos, pela família, enfim, pelos aparelhos ideológicos que reproduzem a lógica patriarcal dominante que inferioriza a mulher e supervaloriza o homem.

Este trabalho tem como base a pesquisa realizada em parceria com a Polícia Civil do Estado de Alagoas, intitulada "As Marias que não calam: perfil das mulheres vítimas de violência após a imple- 
mentação da Lei Maria da Penha em Maceió/AL”, que teve como objetivo conhecer o perfil das mulheres que denunciaram seus agressores a partir do período de vigência da Lei Maria da Penha (de setembro de 2006 a setembro de 2009), bem como conhecer quem são esses agressores, o que fazem, onde moram etc.

O intuito é identificar, a partir dos Boletins de Ocorrências (BOs) e das informações contidas neles, quem são esses homens agressores que violentam cotidianamente as mulheres, traçar um perfil que possibilite ao poder público identificar e adotar políticas públicas para o enfrentamento da violência sofrida pelas mulheres, e que em sua grande maioria é realizada por pessoas que nutrem uma relação de afeto e/ou que compartilham o mesmo espaço doméstico. Este texto faz um recorte dos dados sobre os agressores denunciados no ano de 2008. Para tanto, foram analisados 2.388 BOs.

\section{Conhecendo o agressor}

Talvez já tenha se tornado possível para um homem fazer a autocrítica dos 6 mil anos de ordem masculina, da dominação exercida pelos homens sobre o conjunto da sociedade. (Roger Garaudy, filósofo francês)

Traçar um perfil dos homens agressores a partir dos BOs das mulheres que denunciaram seus agressores no ano de 2008 foi, ao mesmo tempo, uma tarefa científica e política, porquanto a violência contra a mulher é um fato que acontece historicamente e que se perpetua através da presente ideia da dominação de um sexo forte (masculino) sobre um sexo frágil (feminino). Assim, 61 anos depois de Simone de Beauvoir denunciar em seu livro $O$ segundo sexo essa relação de dominação e opressão das mulheres, ainda é possível encontrar tal realidade no seio da sociedade, o que pode se observar nos dados analisados neste trabalho. Mais do 
que produzir um trabalho acadêmico, este texto é uma denúncia da situação de milhares de "Marias" que sofrem as mais diversas formas de violência, seja por meio da força física, psicológica ou intelectual, para tolher sua liberdade.

A primeira forma de violência e a mais frequente é a ameaça que o namorado, noivo, marido ou ex-marido realiza de forma muitas vezes velada e dissimulada em nome de um amor, ciúme, de problemas no trabalho, com a família, do uso de álcool e outras drogas etc. Contudo, diversos estudos apontam a ameaça como a porta de entrada para outros tipos de violência.

É necessária a compreensão de que a violência não se resume ao uso da força física, mas também a qualquer ameaça de usá-la. Ou seja, a violência está diretamente relacionada à imposição do poder, quando um obriga o outro a se submeter a sua vontade e/ou desejo através da força ou do medo. Ao analisar os dados, a ameaça representa $45 \%$ das denúncias, ou seja, 1.033 dos BOs, sendo seguida por 962 casos de lesão corporal $(40 \%), 114$ denúncias de difamação $(5 \%)$, 54 queixas de injúria $(2 \%)$ e 20 casos de calúnia $(1 \%)$. Vale a pena chamar a atenção ao percentual de $7 \%$ em que se coloca a opção de "outros”, o que leva a indagar quais são esses outros tipos de violência que a mulher sofre no seu cotidiano.

A Lei Maria da Penha é clara quando define as formas de violência contra a mulher:

I - a violência física, entendida como qualquer conduta que ofenda sua integridade ou saúde corporal; II - a violência psicológica, entendida como qualquer conduta que lhe cause dano emocional e diminuição da auto-estima ou que lhe prejudique e perturbe o pleno desenvolvimento ou que vise degradar ou controlar suas ações, comportamentos, crenças e decisões, mediante ameaça, constrangimento, humilhação, manipulação, isolamento, vigilância constante, perseguição contumaz, insulto, chantagem, ridicularização, exploração e limitação do direito de ir e vir ou qualquer outro meio que lhe cause prejuízo à saúde psicológica e à autodeterminação; III - a violência sexual, en- 
tendida como qualquer conduta que a constranja a presenciar, a manter ou a participar de relação sexual não desejada, mediante intimidação, ameaça, coação ou uso da força; que a induza a comercializar ou a utilizar, de qualquer modo, a sua sexualidade, que a impeça de usar qualquer método contraceptivo ou que a force ao matrimônio, à gravidez, ao aborto ou à prostituição, mediante coação, chantagem, suborno ou manipulação; ou que limite ou anule o exercício de seus direitos sexuais e reprodutivos; IV - a violência patrimonial, entendida como qualquer conduta que configure retenção, subtração, destruição parcial ou total de seus objetos, instrumentos de trabalho, documentos pessoais, bens, valores e direitos ou recursos econômicos, incluindo os destinados a satisfazer suas necessidades; V - a violência moral, entendida como qualquer conduta que configure calúnia, difamação ou injúria. (BRASIL, 2006, grifo nosso)

Assim, esta pesquisa demonstra que as mulheres alagoanas sofrem as diversas formas de violência e que os agressores utilizaram diversos instrumentos, entre eles: 663 dos agressores utilizaram chute/soco, perfazendo um total de $28 \% ; 26 \%$ utilizaram faca/canivete (89); $2 \%$ dos casos utilizaram pedra/pau (51); e $1 \%$ das denúncias tiveram arma de fogo como instrumento utilizado na agressão (19). Também, os dados revelam que 228 mulheres que afirmaram que os agressores não utilizaram nenhum tipo de instrumento $(9 \%), 722$ mulheres que não responderam e 616 denunciantes que colocaram a opção "outros", perfazendo um total de $56 \%$ do total das denúncias e dificultando uma análise mais detalhada do perfil da agressão dessas mulheres. Isso dificulta não só a análise, mas também a proposição de políticas públicas que erradiquem a violência contra a mulher.

Os dias da semana em que mais acontece a violência são domingo (503 casos ou $21 \%$ ) e sábado (357 casos ou $15 \%$ ); seguidos pela segunda-feira (338 casos ou $14 \%$ ), quinta-feira (316 casos ou $13 \%$ ), sexta-feira (299 casos ou 13\%), quarta-feira (285 casos ou $12 \%$ ) e terça-feira (277 casos ou $12 \%$ ). Contudo, mesmo diante da 
constatação de que a violência contra a mulher acontece mais nos finais de semana, as Delegacias da Mulher só funcionam durante os dias úteis da semana, o que demonstra uma demanda urgente, mas não cumprida pelo Estado, dificultando o acesso das mulheres a fazer a denúncia. Muitas delas acabam indo fazer as denúncias, quando de urgência, em delegacias comuns, que não estão preparadas pra receber a mulher violentada. Ou em outros casos, que são mais comuns, a denúncia só é encaminhada na segunda-feira, quando a delegacia reabre.

Quanto ao local do fato, 1.657 dos BOs apontam que a violência acontece na própria casa da vítima $(70 \%), 223$ mulheres foram violentadas em via pública, representando $9 \%, 107$ casos de agressão aconteceram na casa da família da vítima (5\%), e 57 das denúncias foram realizadas no trabalho $(2 \%)$. Um dado representativo é o fato de que $14 \%$ das denunciantes não informaram o local da ocorrência, perfazendo um número de 344 BOs sem identificação do local da violência. Esse dado revela a permissão social implícita e explícita ao não reconhecimento da violência contra a mulher como uma violação dos direitos humanos.

O fato de a violência acontecer dentro do espaço doméstico e por pessoas da família ratifica a velha dicotomia público e privado que o movimento feminista e de mulheres dos anos 70 e 80 tanto enfrentou com o lema “o pessoal é político”. Buscava-se a afirmação de que o Estado deveria intervir na questão da violência doméstica (naturalizada historicamente) e afirmava-se categoricamente que em briga de marido e mulher, o Estado deve sim "meter a colher", porque essa briga não significava um problema doméstico, periférico, mas violava os direitos das mulheres enquanto cidadãs. Nesse período é que as Delegacias de Mulheres foram instaladas em diversas capitais. Contudo, romper essa lógica machista e preconceituosa que assegura ao homem o poder de vida e de morte sobre a mulher ainda é um desafio da contem- 
poraneidade, expresso nos dados aqui informados e nas notícias diárias publicadas pelos meios de comunicação.

A pesquisa, ao revelar que a violência contra a mulher ocorre em sua maioria no ambiente familiar, demonstra o caráter perverso e cruel daquela, uma vez que o lar geralmente é visto como um local acolhedor, de conforto, de amor e segurança. Assim, esse lar idealizado como o lugar do amor revela outra perspectiva, em que ele aparece como o espaço do conflito e da violência.

Gráfico 1 - Local onde acontece a violência

\section{Local do Fato}

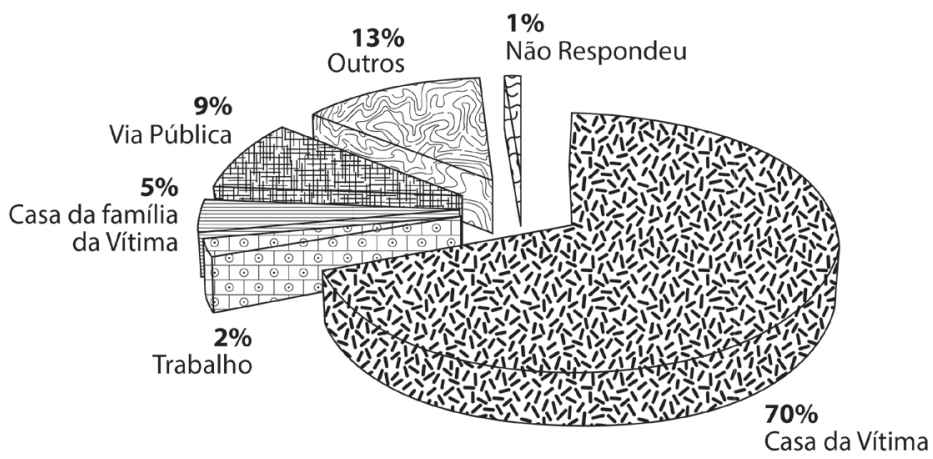

Fonte: Mesquita (2010).

Ao analisar a afinidade da vítima com o autor da violência, 83\% são pessoas que têm ou tiveram uma relação afetiva amorosa com a mulher (companheiro, ex-companheiro, namorado, ex-namorado, noivo, ex-noivo, pai de filho/a): $42 \%$ são casados ou moram juntos (1.004); 39\%, ex-namorado ou ex-companheiro (944); $1 \%$, namorado ou noivo (32); $1 \%$ pai de seu filho/a (34); $6 \%$ tio ou cunhado ou sobrinho ou sogro ou genro (129); $5 \%$ pai ou padrasto ou irmão (122); $2 \%$ filho (50); $3 \%$ outros (62); e 1\% não respondeu (13). Isso revela uma tarefa que muitas feministas, entre elas, Kate Millett, Betty Friedan, Juliet Mitchell e Shulamith Firestone, tentaram realizar: "dessantificar a família e desmistificar a mater- 
nidade.” (DIETZ, 1999, p. 48) É essa santificação da família e do lar que produz e reproduz a cultura do silêncio e, consequentemente, a perpetuação da violência. É a manutenção de um "amor romântico" idealizado e inculcado nas cabeças das mulheres e homens que reforça a tese do "ruim com ele, pior sem ele" e autoriza socialmente o silêncio que encobre a violência contra a mulher.

Gráfico 2 - Afinidade da vítima com o agressor

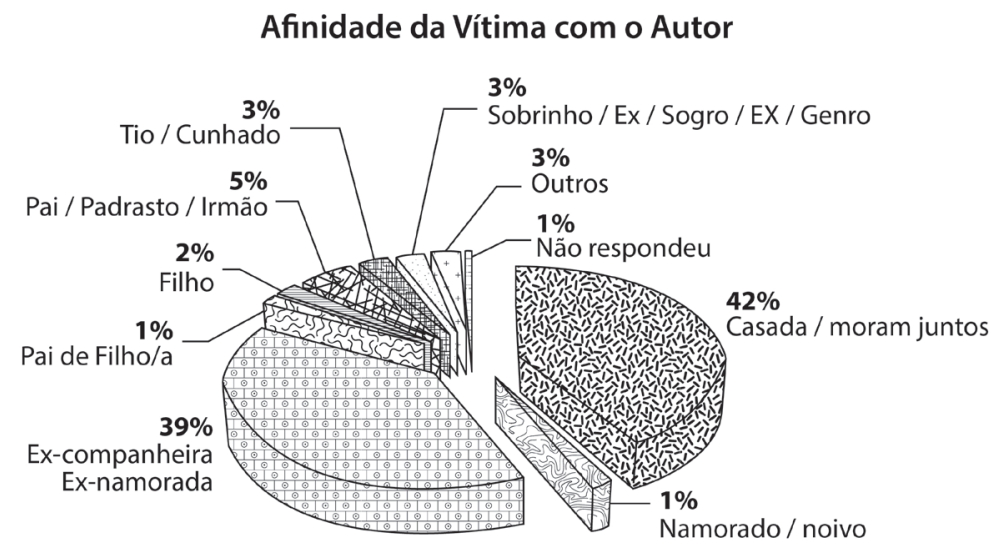

Fonte: Mesquita (2010).

Ao analisar os Boletins de Ocorrências (BOs), é revelado um perfil dos agressores, que são, em sua maioria, pertencentes à faixa etária de 26 a 40 anos (910 ou 38\%), seguidos de 15 a 25 anos (325 ou 14\%); os que têm entre 41 a 55 anos são 325 ou $14 \%$ e os que têm mais de 56 anos são 58 , o que corresponde a $2 \%$. Houve ainda 741 BOs que não responderam a esse item. 
Gráfico 3 - Faixa etária dos agressores

\section{Autor da violência segundo a Idade}
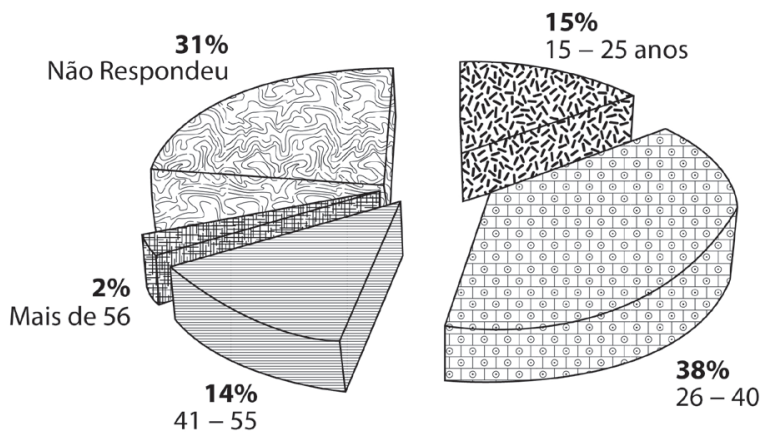

Fonte: Mesquita (2010).

Quanto ao processo educacional, os agressores são: 578 alfabetizados, 383 com ensino fundamental, 288 com nível médio, 135 analfabetos e 77 com nível superior. Já 927 dos BOs estavam sem resposta.

Gráfico 4 - Grau de Instrução dos agressores

\section{Autor segundo o Grau de Instrução}

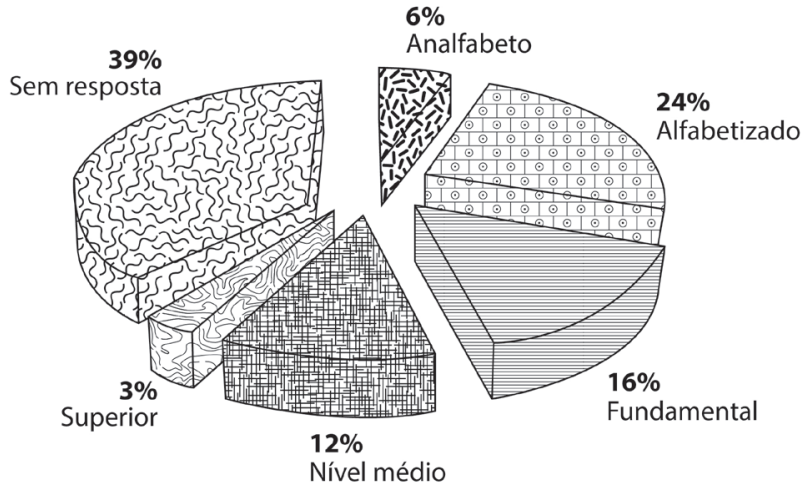

Fonte: Mesquita (2010). 
Quando se analisa a profissão dos autores da violência, os homens/agressores estão distribuídos segundo a tabela abaixo:

Tabela 1 - Autor segundo a profissão

\begin{tabular}{ccc}
\hline PROFISSÕES & QUANTIDADE & PERCENTUAL \\
\hline Autônomo & 154 & $6 \%$ \\
Aposentado & 43 & $2 \%$ \\
Estudante & 35 & $1 \%$ \\
Comerciante & 65 & $3 \%$ \\
Pedreiro & 136 & $6 \%$ \\
Motorista & 83 & $3 \%$ \\
Professor & 8 & $0 \%$ \\
Servidor público & 42 & $6 \%$ \\
Vendedor & 39 & $1 \%$ \\
Desempregado & 214 & $9 \%$ \\
Outros & 771 & $32 \%$ \\
Não respondeu & 252 & $11 \%$ \\
Autor desconhecido & 546 & $23 \%$ \\
Total & 2388 & $100 \%$ \\
\hline
\end{tabular}

Fonte: Mesquita (2010).

Os homens autores da infração moram, em sua maioria (26\%), na área do Grande Tabuleiro (áreas periféricas em que a população é totalmente desassistida pelo poder público) e estão assim distribuidos: $8 \%$ no Tabuleiro (187), $9 \%$ no Jacintinho (211), 5\% no Benedito Bentes (129), 5\% no Vergel do Lago (110), 3\% no Farol (62), 3\% no Trapiche (72), 4\% na Ponta Grossa (91), 2\% no Clima Bom (52), 2\% na Jatiúca (54), 1\% no Prado (32), 0\% no Santos Dumont (14), $1 \%$ no Centro (30), $26 \%$ não responderam (613) e $31 \%$ em outros bairros (731). 


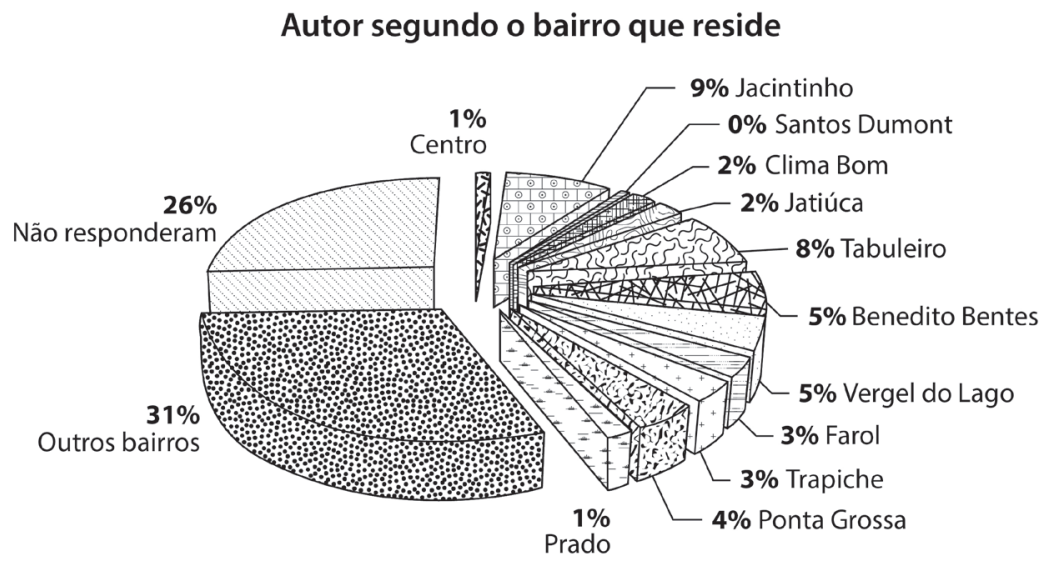

Fonte: Mesquita (2010).

$\mathrm{O}$ vetor raça/etnia demonstra a fragilidade dos BOs por não serem realizados de forma séria como um instrumento não só burocrático, mas que possibilite a análise real do perfil. Nesse ponto, temos $73 \%$ das respostas como "não respondeu", ou seja, 1.736 homens não podem ser identificados quanto à sua raça/etnia. Dos BOs respondidos, o item "raça" fica assim definido pelas mulheres que denunciaram: $17 \%$ parda $(412), 8 \%$ branca $(186), 2 \%$ preta (48), 5 amarela e 1 sarará, o que não significa nem $1 \%$.

A Lei Maria da Penha tem o papel de punir os agressores e consequentemente erradicar a violência doméstica, o que significou uma vitória para o movimento feminista e de mulheres que lutaram pela desnaturalização da violência contra a mulher. Assim, ela parte da concepção de que a violência doméstica significa toda ação ou omissão que prejudique o bem estar da mulher, podendo ocorrer de diversas formas: integridade física, psicológica ou a liberdade e o direito total ao desenvolvimento de um membro familiar. No entanto, é notório, através desses dados, que, apesar 
de a lei estar em vigor desde setembro de 2006, a violência ainda é um fato concreto presente na vida da mulher alagoana.

\section{Violência contra a mulher e o patriarcado moderno}

Resgatar como as relações entre homens e mulheres estão engendradas, ou seja, buscar compreender a historicidade das relações de poder e de dominação que alimentam a violência cometida contra a mulher por pessoas que elas nutrem ou nutriram algum tipo de afeto, não é um exercício simplista da busca de origens que normatizam verdades essencialistas ${ }^{5}$ e universais, e tampouco aceitar explicações evolucionistas.

A lei rompe com os preceitos patriarcais, quando estes reforçam o pertencimento das mulheres aos homens, o binômio dominação-submissão instituído na sociedade e referendado na história, nas leis e no processo de conhecimento. É o que Bourdieu (1999) chama de "ordem natural das coisas", a qual transforma as diferenças em desigualdades, polarizando o mundo em masculino e feminino. Essa construção é baseada numa superioridade masculina que, de forma "invisível", ${ }^{6}$ é imposta à ciência, à história, às leis e às relações sociais.

Arbitrária em estado isolado, a divisão das coisas e das atividades (sexuais e outras) segundo a oposição entre o masculino e o feminino [...] num sistema de oposições homólogas, alto/baixo, e cima/embaixo [...] fora/dentro, público/privado, etc que, para alguns, correspondem a movimentos do corpo [...]. Esses esquemas de pensamento, de aplicação universal, registram como que diferenças de natureza [...]. a divisão dos sexos parece

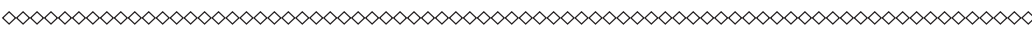

5 Sobre essa discussão, ver Rosaldo (1995).

6 As aspas ressaltam que essa dominação masculina não é invisível. Ao contrário, ela se manifesta seja por meio do "consentimento" (produzido e repassado nas práticas sociais), seja por meio da violência (as pesquisas apontam que a cada 15 segundos uma mulher é vítima de violência). 
estar 'na ordem das coisas' [...] como se também as coisas fossem sexuadas. (BOURDIEU, 1999, p. 16-17)

As normas patriarcais presentes em nossa sociedade constituem e são constituídas pela violência de gênero cometida contra a mulher em sua maioria por pessoas que mantêm ou mantiveram relações afetivas. Ou seja, o patriarcado estabelece as relações hierárquicas entre homens - o patriarca (garantindo o poder de dominar, explorar e oprimir) e as mulheres (impondo a subserviência e a obediência). Para Koller e Narvaz (2006, p. 50), “[...] O patriarca tinha sobre seu poder a mulher, os filhos, os escravos e os vassalos, além do direito de vida e de morte sobre todos eles.”

Como diz Pateman (1993, p. 167), "O poder natural dos homens como indivíduos (sobre as mulheres) abarca todos os aspectos da vida civil. A sociedade civil como um todo é patriarcal. As mulheres estão submetidas aos homens tanto na esfera privada como pública." Esse poder foi perpetuado mediante várias legislações ${ }^{7}$ que asseguravam aos homens tal direito.

Desta forma, ao passo que se produz e reproduz cotidianamente "o direito natural conjugal dos homens sobre as mulheres, como se cada homem tivesse o direito natural de poder sobre a esposa, há um patriarcado moderno.” (KOLLER; NARVAZ, 2006, p. 50) Essa perspectiva fica bem clara nos BOs, quando as mulheres relatam a violência vivenciada e as ameaças: "se você não for minha, não vai ser de ninguém", "se você me deixar, eu mato você", "você é minha mulher e tem que ficar comigo pra sempre", "você não pode me deixar porque você é minha", "eu que decido quando vai acabar". Também esse "patriarcado moderno" baseado no direito natural do homem sobre a mulher fica explícito quando o agressor diz à delegada: “doutora, porque eu tô

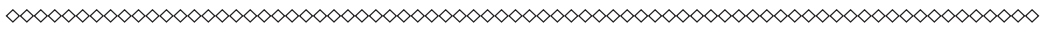

7 É somente em 1827 que surge a primeira lei sobre educação das mulheres, permitindo que frequentassem as escolas elementares. As instituições de ensino mais adiantado eram proibidas a elas e o direito ao voto feminino só aconteceu em 1932. 
preso? Eu bati foi na minha mulher!"' É esse "direito natural” dos homens sobre as mulheres que permite e fabrica socialmente a violência doméstica.

À ordem simbólica do patriarcado se remetem instituições como os parlamentos, os estados, a idéia da lei igual para todos, os tribunais, os exércitos, as instituições consideradas modernas e que continuam considerando-se indispensáveis, se bem que algumas de elas vislumbrem já a crise no seu horizonte. (MULHERES DE MILÃO, 1998, p. 49)

Cabe destacar que pensar o patriarcado como conceito de análise das relações sociais implica historicizá-lo, ou seja, compreendê-lo como um conceito não fixo, histórico e mutável. É pensá-lo em suas variações históricas, temporais, geográficas e sociais.

\section{Considerações finais}

O que significa amar? Amar é escolher. Para amar, é preciso ser livre. ${ }^{9}$

(Flora Tristan)

Para analisar o perfil da violência, a interseccionalidade é fundamental nesse processo, uma vez que aponta para uma perspectiva teórico-metodológica de pensar as diversas formas de discriminação, opressão e subordinação das mulheres, ou seja, perceber como as categorias de gênero, raça/etnia, classe social e até geracional se entrecruzam, construindo esse espaço de violência em que as mulheres alagoanas estão imersas. Como bem ensina Crenshaw (2002, p. 177), a interseccionalidade "[...] trata

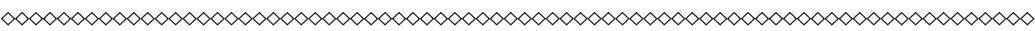

8 Depoimento da delegada Lucimônica.

9 Flora Tristan, avó de Paul Gauguin, já no século XIX, expressava o pensamento de que "Amar é escolher e para amar é preciso ser livre", ao argumentar sobre a importância das contribuições das mulheres para a construção e evolução da cultura, que ela não chegou efetivamente a presenciar, morta aos 41 anos em Bordeaux. 
da forma pela qual o racismo, o patriarcalismo, a opressão de classe e outros sistemas discriminatórios criam desigualdades básicas que estruturam as posições relativas de mulheres, raças, etnias, classe e outras."

No processo de leitura e análise dos BOs ficam nítidas as suas fragilidades, seja no preenchimento, pois são feitos de forma aleatória, sem uma preocupação de retratar a realidade para possibilitar uma melhor compreensão dos fatos acontecidos, seja no próprio instrumental, que tem inúmeras lacunas na identificação da agressão. Os BOs poderiam representar um complexo de informação sistematizada para a identificação da violência, bem como o lócus privilegiado de pesquisas sobre seu perfil, mostrando os aspectos de gênero, raça, etnia, classe etc. Contudo, devido às respostas serem parciais, incompletas e muitas vezes não preenchidas, não permitem uma análise mais aprofundada das mulheres e tampouco dos agressores a partir da proposta da interseccionalidade. Os dados que deveriam ser preenchidos no $\mathrm{BO}$ são fundamentais para traçar o perfil da violência e, assim, criar políticas públicas com uma perspectiva de gênero, no intuito de possibilitar a efetivação de direitos e empoderamento das mulheres através de uma ação mais eficaz por parte do Estado no enfrentamento da violência contra a mulher.

É importante ressaltar a importância das denúncias como momento de desnaturalização e subversão dos costumes, da lógica de dominação e opressão das mulheres. Essa atitude significa a possibilidade de essas mulheres romperem, ou pelo menos desestabilizarem, a lógica patriarcal de gênero que banaliza a violência do homem contra a mulher e saírem desse lugar de subalternidade onde foram colocadas historicamente. A Lei Maria da Penha é fundamental nesse processo, contudo, ela sozinha não é capaz de dar conta desse universo. Por isso, é importante a elaboração e a implementação de políticas públicas, com recorte de raça, etnia, 
classe social e geração, para dar conta dessas múltiplas expressões da questão social.

Nesse sentido, é imprescindível lembrar a importância das Conferências municipais, estaduais e federais, do Pacto Nacional pelo Enfrentamento à Violência, do Plano Nacional de Políticas para as Mulheres, do Atendimento à Mulher (Ligue 180), dos Programas Pró-Equidade de Gênero, Mulheres Donas da Própria Vida e outros programas e projetos nacionais e locais como espaços de fortalecimento das lutas das mulheres em defesa de uma sociedade mais justa, democrática e plural, em que mulheres e homens possam viver relações igualitárias de direitos políticos, sociais e econômicos em sua plenitude.

Por fim, para falar sobre a violência é imprescindível entender a história da sociedade, uma história androcêntrica marcada fortemente pelo vetor do "arquétipo viril", como bem nos menciona Amparo Moreno. Esse arquétipo viril é o modelo de todas as coisas existentes que se fundamentam na soberania masculina. E a violência contra a mulher, enquanto uma das formas mais agressivas que perpetua esse arquétipo viril, é apoiada e consentida cotidianamente pela mídia (através das músicas, novelas, filmes, propagandas etc.), pela escola, pelas instituições religiosas, pelos partidos políticos, pelas famílias, enfim, por todos os aparelhos ideológicos que reproduzem a lógica patriarcal dominante. É essa ordem de cunho preconceituoso, machista, classista, racista, que foi produzida/reproduzida historicamente e mantida até os dias atuais, que justifica as desigualdades de gênero e, consequentemente, a violência contra a mulher. Isso remete ao entendimento de que a violência tolhe a liberdade, um princípio fundamental dos direitos humanos, e que a liberdade é condição sinequa non para o amor. Assim, é necessário desmistificar os atos e ações violentas justificadas em nome do amor. Amor e liberdade representam a face da mesma moeda e, como canta Flávia Wensceslau (2005), “a 
liberdade é um abraço lilás”, e foi almejando esse abraço lilás, essa liberdade, que inúmeras mulheres foram desprezadas, apedrejadas, queimadas e mortas ao longo da história em sua luta cotidiana por direitos sociais, políticos, econômicos e culturais.

\section{Referências}

BOURDIEU, P. A dominação masculina. Rio de Janeiro: Bertrand Brasil, 1999.

BRASIL. Lei $n$. 11.340, de 7 de agosto de 2006. Cria mecanismos para coibir a violência doméstica e familiar contra a mulher, nos termos do $\$$ $8^{\circ}$ do art. 226 da Constituição Federal, da Convenção sobre a Eliminação de Todas as Formas de Discriminação contra as Mulheres e da Convenção Interamericana para Prevenir, Punir e Erradicar a Violência contra a Disponível em: <http://www.planalto.gov.br/ccivil_03/_ato20042006/2006/lei/l11340.htm>. Acesso em: 17 maio 2015.

CRENSHAW, K. Documento para o encontro de especialistas em aspectos da discriminação racial relativos ao gênero. Revista Estudos Feministas, Santa Catarina, v.10, n.1, jan., p.171-188, 2002.

DIETZ, M. G. Cidadania com cara feminista: o problema com o pensamento maternal. In: LAMAS, M.(Org.). Cidadania e feminismo. São Paulo: Melhoramentos, 1999. p. 48-69.

MESQUITA, A. P. de. A violência contra a mulher em Maceió: o perfil dos agressores. In: SIMPÓSIO BAIANO DE PESQUISADORAS/ES SOBRE MULHERES E RELAÇÕES DE GÊNERO, 16., Salvador. Anais...Salvador: PPGNeim, 2006.

MESQUITA, A. P. de. As Marias que não calam: perfil das mulheres vítimas de violência após a implementação da Lei Maria da Penha em Maceió/AL. In: SEMINÁRIO INTERNACIONAL FAZENDO GÊNERO. Florianópolis, 2010. Anais eletrônicos... Florianópolis: Instituto de Estudos do Gênero, 2010. Disponível em: <http://www.fazendogenero. ufsc.br/9/resources/anais/1278269236_ARQUIVO_Texto_Competo_ asmariasFG9.pdf $>$. Acesso em: 2015.

MUJERES DE MILAN. "El final del Patriarcado". El Viejo Topo, Madrid, fev. 1997. 
NARVAZ, M. G.; KOLLER, S. H. Famílias e patriarcado: da prescrição normativa à subversão criativa. Rev. Psicol. Soc., Porto Alegre, v. 18, n. 1, jan./abr., 2006. Disponível em: <http://hdl.handle. net/10183/20260>. Acesso em: 17 maio 2015.

ORGANIZAÇÃO DOS ESTADOS AMERICANOS (OEA). Convenção De Belém Do Pará. Pará, 1994. Disponível em: <http://www.cidh.org/ Basicos/Portugues/m.Belem.do.Para.htm>. Acesso em: 20 abr. 2015. PATEMAN, C. O contrato sexual. Rio: Paz e Terra, 1993.

QUEIROZ, F. M. Não se rima amor e dor: cenas cotidianas de violência contra a mulher. Mossoró, RN: UERN, 2008.

ROSALDO, M. O uso e o abuso da antropologia: reflexões sobre o feminismo e o entendimento intercultural. Revista Horizontes Antropológicos, Porto Alegre, v. 1, n.1, p. 11-36, 1995.

SAFFIOTI, H. I. B. A ontogênese do gênero. In: STEVENS, C. M. T.; SWAIN, T. N. A construção dos corpos: perspectivas feministas. Florianópolis: Ed. Mulheres, 2008.

SAFFIOTI, H. I. B. Gênero, patriarcado, violência. São Paulo: Perseu Abramo, 2004. (Coleção Brasil Urgente).

SARDA, A. M. En torno alandrocentrismoenla história. CUADERNOS inacabados: el arquétipo viril protagonista de la história: ejercicios de lecturas no androcentricas. 2.ed. Barcelona: La Sal, 1987. p. 17-52.

SARDENBERG, C. M. B. A violência simbólica de gênero e a lei “antibaixaria” na Bahia. Salvador, 2011. Mimeo.

SARDENBERG, C. M. B. A violência simbólica de gênero e a lei "antibaixaria" na Bahia. Observatório de Monitoramento da Lei Maria da Penha - OBSERVE-, NEIM/UFBA, 30 ago. 2011. Disponível em: 〈http://www.observe.ufba.br/noticias/exibir/344〉. Acesso em: 17 maio 2015.

SARDENBERG, C. M. B. Da crítica feminista à ciência a uma ciência feminista? In: COSTA, A. A.; SARDENBERG, C. M. B. (Org.). Feminismo, ciência e tecnologia. Salvador: UFBA: NEIM: REDOR, 2002.

WENCESLAU, Flávia. Toda bela cor. Intérprete: Flávia Wenceslau. In: WENCESLAU, Flávia. Agora. [S.l.: s.n.], 2005. Faixa 7. Disponível em: 〈http://som13.com.br/flavia-wenceslau/toda-bela-cor >. Acesso em: 2015 . 


\title{
VIOLÊNCIA DE GÊNERO NA TRAMA GERACIONAL ${ }^{1}$
}

\author{
Eulália Lima Azevedo
}

\section{Introdução}

Neste trabalho, busco lançar um pouco de luz sobre a discussão relacionada à dimensão geracional da violência de gênero. Busco ampliar, por conseguinte, o pouco tratamento dado a essa questão, tanto do ponto de vista da ação política quanto da atenção teórica, especialmente a sua ausência nas análises feministas. Vejo como problemática tal situação, na medida em que as pesquisas sobre a violência contra a pessoa idosa demonstram o maior número de vítimas desse tipo de violência entre as mulheres e o maior número de agressores entre os homens. (PASINATO; CAMARANO; MACHADO, 2006; SOUZA et al., 2004) Eu pude confirmar esses resultados numa pesquisa recente que realizei na

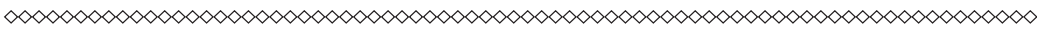

1 Este trabalho é uma versão modificada de parte de um dos capítulos da minha tese de doutoramento, intitulada: Um palco de múltiplas vozes: a nova invenção dos/as idosos/as em luta pela cidadania. (AZEVEDO, 2010) 
Delegacia Especial de Atendimento ao Idoso da Bahia (Deati/BA), cujo resultado apresento neste trabalho.

Os dados objetos deste estudo foram construídos, de um lado, com base na observação direta de conferências, seminários e outras atividades organizadas diretamente pelo Fórum Permanente em Defesa do Idoso $^{2}$ ou resultado da articulação entre este e as Secretarias da Justiça e da Segurança Pública, nas quais as/os idosas/os figuram como público alvo. De outro, pela organização das informações constantes dos dados sistematizados pela Deati/BA, além do levantamento de registros diretamente dos Boletins de Ocorrência (BOs) da mesma, gentilmente disponibilizados por sua coordenação. Para levantar esses registros, levei em conta três tipos de maus-tratos dentre as mais frequentes ocorrências nos registros da Deati/BA - maus-tratos físicos (lesão corporal), exploração financeira (apropriação indébita) e maus-tratos diversos (abusos em geral), considerando que as agressões psicológicas tendem a permear todas as demais. Tomei para cada um desses tipos de violência o período de funcionamento da Deati em Salvador, desde sua instalação, em 31 de Julho de 2006, a agosto de 2008, um registro do início, outro do meado e outro do final de cada mês, e constituí uma amostra com um total de 218 ocorrências. Trata-se de uma amostra aleatória para fins de análise qualitativa de formas de violência, que contou ainda com o depoimento da delegada titular da Deati/BA, colhido em entrevista no dia 24 de setembro de 2008.

Ao pensar essa problemática, faz-se necessário inseri-la no contexto das profundas mudanças no campo demográfico mundial que anunciam uma revolução em todos os domínios da vida humana - econômicos, políticos, sociais, culturais e psicológicos.

$\infty<\infty<\infty<\infty<\infty<\infty<\infty<\infty<\infty<\infty<\infty<\infty<\infty<\infty<\infty<\infty<\infty<\infty<\infty<\infty<\infty<\infty<\infty<\infty<\infty<\infty<\infty<\infty$

2 O Fórum de Defesa da Pessoa Idosa, fundado em 27 de janeiro de 2004, com o objetivo de implementar o Estatuto do Idoso e sensibilizar as mulheres idosas para participarem do movimento político, constituiu-se como campo empírico desta pesquisa. 
Merece destaque compreender a ressignificação cultural da idade cronológica como princípio norteador de novos direitos e deveres. Em diferentes sociedades e tempos históricos, o sentido político e organizador do sistema social define-se na ritualização das fronteiras etárias, mediante a apropriação e elaboração simbólica do processo biológico do curso da vida. Demarca-se, assim, etapas, fases ou ciclos diferentemente significados em cada cultura. No bojo dos poderes diferenciados atribuídos socialmente a cada ciclo da vida ocorre uma desautorização política e social em relação à pessoa idosa.

Busco dimensionar o fenômeno da ocorrência da violência contra a/o idosa/o na Região Metropolitana de Salvador (RMS), visando reunir elementos para avaliar o resultado do empenho do Fórum já referido quanto à implementação das definições do Estatuto do Idoso, traçando um perfil preliminar das vítimas e dos agressores, bem como a frequência e tipos de maus-tratos, para situar as condições de efetivação da política no que concerne a essa questão. Compreendendo também que o levantamento preliminar desses elementos seja um dos primeiros passos para o estudo do mesmo, visando contribuir para que a sociedade perceba essa questão como um problema social a ser enfrentado.

No processo de construção desses dados surgiu uma dificuldade em relação à ausência de padronização entre a tipologia da Deati/BA e a encontrada na literatura sobre o tema, o que dificultou o estudo comparativo relacionado aos tipos de maus-tratos. Para tornar possível uma análise comparativa entre os registros de Salvador/BA e dados de outras pesquisas disponíveis na literatura nacional, frente ao grande elenco de tipos de abusos registrados nos BOs pesquisados, reagrupei a tipologia dos maus-tratos arrolados nesses boletins em seis grandes grupos, conforme sistematizado na Tabela 1 a seguir, fazendo uso da classificação de Minayo (2004) e da própria Deati/BA. 
Tabela 1 - Número de queixas por tipos de Violência Contra o/a Idoso/a.

\begin{tabular}{|c|c|c|c|c|c|c|c|c|}
\hline \multicolumn{2}{|c|}{$\begin{array}{l}\text { SEMESTRES/ANOS } \\
\text { TIPO DE VIOLÊNCIA }\end{array}$} & $\begin{array}{l}2^{0} \\
\text { SEM. } \\
2006\end{array}$ & $\begin{array}{l}1^{0} \\
\text { SEM. } \\
2007\end{array}$ & $\begin{array}{l}2^{0} \\
\text { SEM. } \\
2007\end{array}$ & $\begin{array}{l}1^{0} \\
\text { SEM. } \\
2008\end{array}$ & $\mathrm{~T}$ & T.GE & $\%$ \\
\hline \multirow[t]{2}{*}{ Abandono } & & 05 & 03 & 03 & 00 & 11 & 11 & 0,2 \\
\hline & Agressão física & 05 & 00 & 00 & 00 & 05 & & \\
\hline \multirow[t]{6}{*}{ Maus-tratos Físicos } & Lesão corporal & 69 & 89 & 98 & 122 & 378 & 384 & 8,5 \\
\hline & Homicídio & 00 & 00 & 00 & 01 & 01 & \multirow{13}{*}{477} & \multirow{13}{*}{10,5} \\
\hline & Apropriação indébita & 30 & 19 & 12 & 07 & 68 & & \\
\hline & Estelionato & 28 & 48 & 36 & 36 & 148 & & \\
\hline & Furto simples & 31 & 38 & 69 & 60 & 198 & & \\
\hline & Furto qualificado & 05 & 02 & 02 & 05 & 13 & & \\
\hline \multirow{8}{*}{ Abuso financeiro } & Roubo qualificado & 00 & 00 & 00 & 02 & 02 & & \\
\hline & Roubo simples & 07 & 08 & 06 & 11 & 32 & & \\
\hline & Invasão domiciliar & 02 & 01 & 02 & 04 & 09 & & \\
\hline & Esbulho possessório sob dano & 01 & 03 & 01 & 00 & 05 & & \\
\hline & Extorsão & 01 & 00 & 00 & 00 & 01 & & \\
\hline & Fraude & 01 & 00 & 00 & 00 & 01 & & \\
\hline & Ameaça & 300 & 276 & 316 & 300 & 1192 & & \\
\hline & Calúnia & 07 & 13 & 12 & 13 & 45 & & \\
\hline \multirow{4}{*}{$\begin{array}{l}\text { Maus-tratos } \\
\text { psicológicos }\end{array}$} & Constrangimento & 65 & 29 & 40 & 20 & 154 & \multirow{4}{*}{2.110} & \multirow{4}{*}{46,} \\
\hline & Difamação & 09 & 05 & 10 & 17 & 41 & & \\
\hline & Injúria & 82 & 162 & 164 & 99 & 507 & & \\
\hline & Perturbação tranquilidade & 44 & 31 & 58 & 38 & 171 & & \\
\hline Abuso sexual & Estupro & 00 & 00 & 02 & 00 & 02 & 02 & 0.0 \\
\hline
\end{tabular}




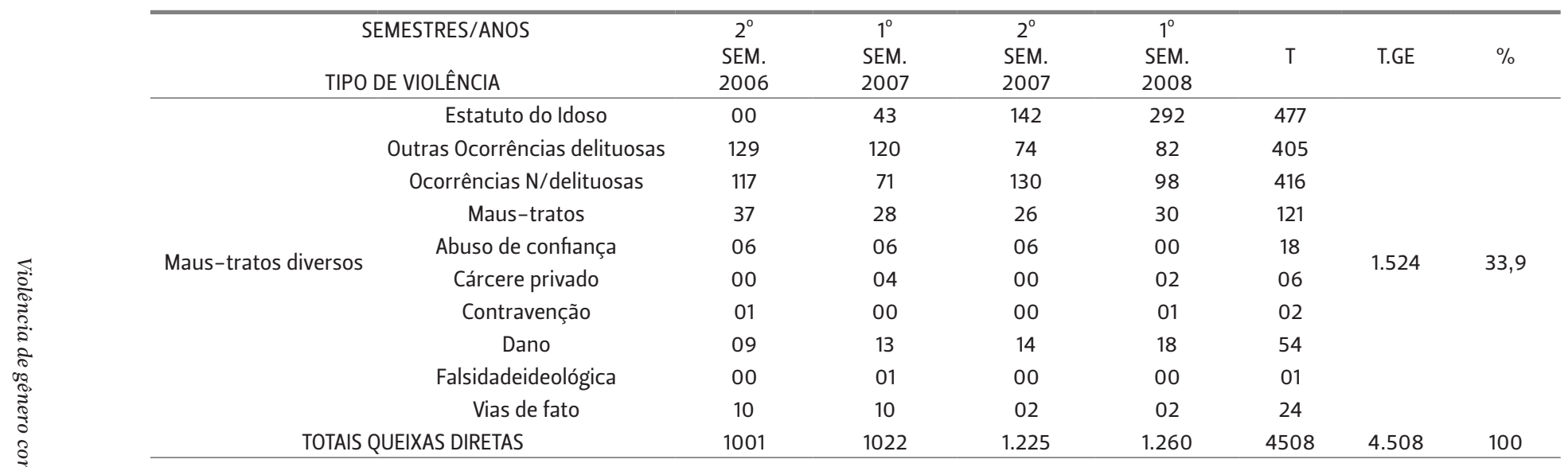

Fonte: Sistematização da autora a partir dos dados primários. (BAHIA, 2006-2008) 
Nessa tabela, a dimensão dessa realidade está desdobrada quanto ao tipo e à frequência dos maus-tratos que sofrem os idosos/as da RMS.

A lesão corporal aparece com o maior número de ocorrências dentre os maus-tratos agrupados como agressão física. O abuso financeiro tem no furto simples a maior incidência, do mesmo modo que a ameaça figura com o maior número de ocorrências entre as agressões psicológicas. Já as agressões tipificadas como crime no Estatuto do Idoso que não se enquadram como agressão financeira ou abandono lideram as agressões agrupadas como maus-tratos diversos. No âmbito das agressões tipificadas como psicológicas (ameaças, calúnias, ofensas verbais, constrangimentos etc.) está, de longe, a maior incidência, vindo em segundo lugar os maus tratos diversos, aqueles casos de difícil enquadramento nas demais categorias classificatórias (certos crimes previstos no Estatuto do Idoso, como perturbação da tranquilidade etc.). O abandono e o abuso sexual aparecem como os maus-tratos de menor incidência.

\section{A análise na dinâmica do contexto}

O cenário mundial de envelhecimento populacional, em que a expectativa média de vida, desde 1950, aumentou em 20 anos, com uma previsão de mais 10 anos até 2050, tem sido marcado por sua especificidade nos países em desenvolvimento, pela espantosa velocidade com que vem ocorrendo. Nessas populações prevê-se um aumento de $8 \%$ para $15 \%$ das pessoas com mais de 60 anos entre 1998 e 2025. Vale ressaltar que no Brasil,como de resto em toda a América Latina, prevê-se que o grupo etário definido como idoso deverá se quadruplicar até 2050, e o mundo, nessa mesma década, deverá alcançar quase 2 bilhões de pessoas, contrastando em muito com os aproximadamente 600 milhões 
de idosas/os que viviam no ano 2000. (BRASIL, 2003) Esses dados demográficos mundiais em permanente transformação anunciam uma revolução em todos os domínios da vida humana - econômicos, políticos, sociais, culturais e psicológicos. Essa transformação nos países em expansão (economia em transição), como o Brasil, que ganha inesperada velocidade como visto acima, configura uma situação única observada no mundo atual, visto que, segundo Minayo (2002), os países europeus levaram cerca de 140 anos para envelhecer. O rápido envelhecimento da população nesses países de economia em transição afeta seriamente as mais diversas dimensões da vida individual e social, tornando mais problemático lidar com suas consequências no âmbito nacional e internacional, visto que ainda lutam pelo desenvolvimento. Nesse contexto, tem sido quase impossível desconhecer os problemas que afetam o contingente da população classificada como idosa. Sua maior visibilidade, bem como a expressão de suas necessidades específicas, vem suscitando discussões polêmicas quanto ao impacto desse fenômeno nas políticas públicas de Proteção Social e se transformando em recente objeto de interesse das Ciências Sociais, embora não lhe seja ainda dada a devida importância.

Uma dessas políticas relacionadas à especificidade da problemática dessa população diz respeito à proteção requerida contra as várias formas de violência que têm as/os idosas/os como alvo, destacando, sobretudo, aquela sofrida no âmbito das relações intergeracionais na família e numa dimensão de gênero. É importante ressaltar, no entanto, que os maus-tratos domésticos que atingem as/os idosas/os não devem ser pensados fora do contexto da violência social/estrutural em que os indivíduos e as comunidades estão inseridos. Muitas vezes, o convívio entre várias gerações num mesmo domicílio, que, via de regra, contribui para facilitar a violência contra as/os mais velhas/os, é imposto pelo empobrecimento da população, em especial nos grandes centros 
urbanos, como os dados empíricos de pesquisa por mim realizada e por muitas outras pessoas evidenciam.O estudo de campo realizado na cidade de Jequié,na Bahia, por exemplo, possibilitou a Souza e colaboradores (2004) observarem que 94\% dos familiares cuidadores dependiam da renda da/o idosa/o. Além disso, a sobrecarga de tarefas impostas às mulheres, tradicionais cuidadoras, afetando seu equilíbrio emocional, bem como a ausência de políticas públicas que auxiliem e atuem como facilitadoras das relações domésticas, se constituem em outros tantos fatores que favorecem relações de violência. (PASINATO; CAMARANO; MACHADO, 2006)

As análises neste capítulo se ancoram no pressuposto teórico de que as relações de poder ocupam lugar central na organização das sociedades. O poder aqui entendido no sentido de uma rede que permeia todo o corpo social, mediado por técnicas e táticas de dominação, segundo expõe Foucault (1979, p. 184):

[...] o poder [...] não é algo que se possa dividir entre aqueles que o possuem e o detêm exclusivamente e aqueles que não o possuem e lhe são submetidos. O poder deve ser analisado como algo que circula, ou melhor, como algo que só funciona em cadeia. Nunca está localizado aqui ou ali, nunca está nas mãos de alguns, nunca é apropriado como uma riqueza ou um bem. O poder funciona e se exerce em rede. Em suas malhas os indivíduos não só circulam, mas estão sempre em posição de exercer este poder e de sofrer sua ação, nunca são o alvo inerte ou consentido do poder, são sempre centros de transmissão [...]

Ainda que o exercício do poder implique muitas vezes a posse de certos bens ou recursos, tomá-lo como tais, isto é, confundi- lo com tais recursos, ou com atributos que os indivíduos possuem, significa negar seu caráter relacional, como interpretado por Young (2000, p. 57): "O poder consiste em uma relação entre quem o exerce e outras pessoas, pela qual ela ou ele comunica intenções e obtém seu consentimento.” Trata-se, de acordo com 
Foucault (1979), de uma relação de forças que se exerce na ação. Esta, como critério de sua existência, expõe a natureza dinâmica das relações de poder como um processo.

É no marco das relações de poder que as sociedades historicamente utilizam como princípio político organizador as idades/ gerações, o sexo, as classes sociais e as raças/etnias. Com exceção das classes sociais, que, como diz Motta (1999), não surgiram da percepção da biologia humana, embora também se expressem no corpo, as demais categorias são socialmente construídas com base na interpretação e elaboração simbólica de aspectos biológicos. As formas como esses princípios são manipulados é que se diferenciam no tempo e nas diferentes sociedades. Com esse entendimento é que várias/os autoras/es ${ }^{3}$ asseguram que o processo biológico do curso da vida foi apropriado simbolicamente para definir a idade cronológica, que historicamente vem sendo utilizada para demarcar, de forma ritualizada, as fronteiras que limitam suas diferentes etapas, fases ou ciclos culturalmente significados, estabelecendo permissões e interdições para cada uma delas. Especificidades biológicas, de acordo com Lenoir (1998), servem de critérios que informam princípios de classificação dos indivíduos no espaço social. Tais princípios geralmente fundamentam as atividades de certas instituições e agentes especializados que os elaboraram e neles ancoram a justificativa da importância de seu surgimento e manutenção. Sob diversos argumentos, o autor vai mostrando como o social trabalha para a produção da noção de idade e dos grupos de idade diferenciados a depender dos condicionantes (sociais, econômicos, políticos, culturais) da realidade. A diversidade desses condicionantes demarca grupos de indivíduos ocupantes de uma posição comum no processo histórico-social definidores de diferentes gerações, de cuja luta emergem os

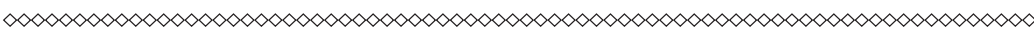
3 Ver trabalhos de Motta (2009, 1999, 2000), Bourdieu (1983), Featherstone (1994), Foracchi (1972), Lenoir (1998) e Rifiotis (2000). 
atributos das diferentes idades, resultado da correlação de forças posta em ação nesse embate geracional. Tal processo não se realiza sem conflito, como de resto qualquer relação perpassada pelo poder. Desse modo, a amplitude e fundamento do poder atribuído a cada momento do ciclo da vida é definido pela natureza das implicações da luta entre as gerações. (LENOIR, 1998). E é nesse sentido que também Bourdieu (1983, p. 112) vai afirmar que a estrutura que define a classificação das idades, bem como a de sexo e de classe, são estruturas de poder que "acabam sempre por impor limites e produzir uma ordem em relação à qual cada um deve se manter em seu lugar.” Assim, as diferentes gerações estabelecem relações que conformam campos de força em disputa, do mesmo modo como as relações em outras dimensões do social como as de gênero, raça e classe social. As relações intergeracionais, como bem disse Motta (2009, p. 8), "[...] por aí devem ser também identificadas, e não apenas pela requerida e alternativa solidariedade.”

Com relação aos idosos, é particularmente intensa sua desautorização, do modo como entende Bourdieu (1983, p. 118-120), "[...] a velhice é um declínio social, uma perda de poder social”, porque, no contexto atual, a concretude dos interesses dos velhos "em remeter os jovens à sua juventude" não tem conseguido alongar o tempo suficiente para fazer face ao novo fenômeno do alongamento do tempo de vida e em razão disso mantém-se quase inalterada a maneira tradicional de efetivar o interesse dos jovens em “remeter os velhos à sua velhice.” Essa desautorização já chegou em certas culturas a um ponto tal de radicalização que Rifiotis (2000), estudando diferentes etnias africanas, assegura que uma rígida divisão de funções etárias que marca a organização dessas tribos leva ao abandono das/os velhas/os em cavernas distantes de suas comunidades para lá morrerem. Essa é a forma encontrada, nessas tribos, para resolver o conflito pela sucessão do poder entre as gerações. Segundo Minayo (2003), nos diversos contextos 
históricos e culturais ocorrem diferentes expressões desse desejo real ou simbólico de morte das pessoas que envelhecem. E que em nossa sociedade, os conflitos intergeracionais, maus-tratos e negligências que tipificam mais frequentemente a violência contra as/os mais velhas/os são expressões desse desejo de morte real e social dessa população. Discutindo essa questão da distribuição social dos poderes e bens, sempre escassos, entre as gerações, Motta (2009, p. 11) assegura:

[...] afinal, entre o descarte, real ou simbólico, dos velhos no passado (RIFIOTIS, 1998; SEEGER, 1980) e o apossamento atual das suas aposentadorias e pensões por filhos e outros parentes, e por empréstimos consignados fraudulentos, deixando-os (ações públicas e privadas) à míngua, há diferença apenas de tempo social e geografia.

O que parece configurar a atualidade do conflito entre as gerações é sua nova intensificação devido ao entrecruzamento das trajetórias das/os mais velhas/os e dos/as mais jovens, não porque estes/as, como entende Bourdieu (1983), estão aspirando assumir "cedo demais" os espaços sociais de poder, mas porque as/os mais velhas/as, com o fenômeno do alongamento do tempo de vida, se sentem, e estão de fato, com vigor suficiente para também estenderem seu tempo nesses espaços. Pensar e criar condições para a convivência adequada das jovens e velhas gerações nos espaços de decisão da organização social se impõe cada vez mais na contemporaneidade. São os valores dessa nova ordem de organização social etária que os velhos em movimento insistem em consolidar em todas as instâncias da sociedade brasileira, mediante estratégias de empoderamento, com especial atenção para o empoderamento das mulheres idosas. 


\section{O segredo que a família quer guardar}

Com a sanção do Estatuto do Idoso, os direitos das/os que envelhecem passaram a contar com um instrumento jurídico que traz como novidade em relação aos já existentes a previsão de pena por seu descumprimento. E mais, toda a sociedade brasileira passa a ter o dever de prevenir, bem como a obrigação de denunciar aos órgãos competentes (autoridades policiais, Ministérios Públicos, Conselhos do Idoso etc.), a ameaça ou a violação desses direitos.

Assim, além de outras questões, o combate à violência contra a idosa/o, uma das principais demandas das/os que envelhecem no Brasil, bem como na Bahia, vem assumindo um lugar de destaque na agenda do Fórum Permanente em Defesa do Idoso. Nesse sentido, um seminário foi promovido pelo Fórum e pela Casa do Aposentado no dia 25 de setembro de 2006. As mulheres figuravam como maioria dos presentes nesse seminário, no qual uma relação de diversas formas de agressão contra esse contingente populacional foi organizada em um folder, que foi distribuído aos participantes do evento. As deliberações da I Conferência Nacional dos Direitos da Pessoa Idosa, no que concerne à violência, foram tomadas como tema na exposição de Maria da Penha, coordenadora do Fórum. As resoluções dessa I Conferência enfocaram principalmente a demanda por campanhas educativas sobre a violência contra a idosa/o, no que diz respeito à segregação, à infantilização e à estigmatização, estimulando as/os idosas/os e a comunidade a denunciarem aos órgãos competentes as diversas formas de violência sofrida. Destacaram a criação, ampliação e implementação em todos os estados e municípios, com garantia de eficiência e eficácia de serviços de proteção a pessoas idosas vitimas de violência no que concerne a delegacias de polícia para atendimento especializado e residências temporárias de acolhimento a idosas/os vítimas de violência doméstica/familiar. Ademais, enfatizam a urgência de 
capacitação dos/as profissionais de todas as especialidades que lidam com idosos/as no âmbito da operação do direito, da proteção, defesa social, saúde, com vistas a habilitá-los para identificar com facilidade e encaminhar o atendimento imediato, qualificado e humanizado. (BRASIL, 2006) Nessa oportunidade, a coordenadora do Fórum Permanente em Defesa do Idoso, ${ }^{4}$ Maria da Penha, conclamou as/os idosas/os presentes a levarem essa discussão a suas entidades, afirmando "porque é preciso reunir todos para irmos às ruas exigir o devido cumprimento dessas resoluções."

A delegada titular da Delegacia de Atendimento ao Idoso em Salvador, Márcia Telma Bittencourt, reafirmou que a luta do movimento dos aposentados/as, pensionistas e idosos foi decisiva para criar e instalar a referida Instituição. A fala do Sr. Gilson Costa, em entrevista no dia 25 de setembro de 2008, reforça essa afirmação: "Foi aqui dentro [do Fórum/Casa do Aposentado] que nasceu a Delegacia do Idoso [...] Os funcionários da delegacia até tomaram curso aqui com a gente, foram dois dias discutindo sobre o Estatuto do Idoso, sobre todos os direitos, para eles se prepararem para assumir bem a função.” E o discurso da delegada vai nessa mesma direção, quando saúda sua equipe como a mais bem preparada da Secretaria de Segurança do Estado em atendimento ao público, salientando que "É nosso dever tratar bem essa população que tanto sofre”. Em entrevista no dia 24 de setembro de 2008, ela continua reafirmando a competência de sua equipe:

A equipe toda, toda a equipe é bastante preparada, os policiais, como eu disse, são especializados, eles fizeram cursos, inclusive, e foram escolhidos a dedo. É uma equipe totalmente coesa, integrada, comprometida com um único objetivo, o de atender bem nossa clientela, que são

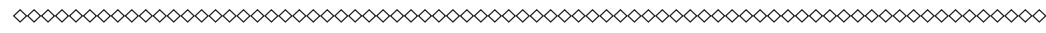

4 Fórum criado pelo movimento dos aposentados e pensionistas da Bahia, em 27 de janeiro de 2004, para articular esse movimento com outras entidades e grupos que trabalham e lidam com a problemática do envelhecimento. 
os idosos. Foi-nos ofertado um curso muito bom, a nós todos, a toda a equipe, eu e às demais delegadas e demais policiais e agentes. Mas todo ele dado, não pela Secretária de Segurança, dado pela sociedade civil. Esse curso foi oferecido pela Casa do Aposentado, foi muito proveitoso.

Ainda no seminário mencionado acima, ela se coloca chocada com a situação de abandono e descaso em que vivem as/os que envelhecem em nossa cidade. Segundo seu depoimento, 679 ocorrências foram registradas em apenas 53 dias, uma média de quase 13 ocorrências diárias.

Esse depoimento revela que a dimensão da violência contra a população idosa na RMS exposta, em parte pelo número de registros jamais imaginado, tomou de surpresa as autoridades públicas e a sociedade de um modo geral. A tendência do alto índice dessas denúncias mantém-se constante nos anos seguintes à implantação da delegacia, como já ilustrada na Tabela 1 acima.

A delegada informou, ainda, que naqueles primeiros dias de funcionamento da Deati/BA, o maior número de vítimas encontrava-se entre as mulheres e o maior número de agressores ficava por conta dos homens, tendência que se manteve por todo o período analisado, como mostra a sistematização da amostra levantada nesta pesquisa, nos BOs da Deati/BA, conforme as Tabelas $2 \mathrm{e}$ 3. Chama a atenção um não esperado índice tão alto de mulheres como agressoras $(40 \%)$, expressão exemplar da intersecção entre dois eixos da opressão que permeiam as relações sociais, a de idade/geração e a de sexo/gênero. 
Tabela 2 - Número de idosas/os vítimas de violência.

\begin{tabular}{ccccc}
\hline \multirow{2}{*}{ ANOS/ SEMESTRE } & \multicolumn{2}{c}{ MULHERES } & \multicolumn{2}{c}{ HOMENS } \\
\cline { 2 - 5 } & $\mathrm{N}^{\circ}$ & $\%$ & $\mathrm{~N}^{\circ}$ & $\%$ \\
\hline $2^{\circ}$ Sem.2006 & 33 & 53 & 30 & 47 \\
$1^{\circ} / 2^{\circ}$ Sem.2007 & 46 & 55 & 38 & 45 \\
$1^{\circ}$ Sem.2008 & 38 & 62 & 23 & 38 \\
TOTAL & 117 & 57 & 91 & 43 \\
\hline
\end{tabular}

Fonte: Sistematização da autora com base em uma amostra dos dados primários registrados nos BOs. (BAHIA, 2006-2008)

Tabela 3 - Número de Agressores/as de idosas/os

\begin{tabular}{ccccc}
\hline \multirow{2}{*}{ ANOS/SEMESTRE } & \multicolumn{2}{c}{ MULHERES } & \multicolumn{2}{c}{ HOMENS } \\
\cline { 2 - 5 } & $\mathrm{N}^{\circ}$ & $\%$ & $\mathrm{~N}^{\circ}$ & $\%$ \\
\hline $2^{\circ}$. Sem. 2006 & 31 & 45 & 38 & 55 \\
$1^{\circ} / 2^{\circ}$. Sem. 2007 & 31 & 34 & 60 & 66 \\
$2^{\circ}$ Sem. 2008 & 30 & 44 & 37 & 56 \\
TOTAL & 92 & 40 & 135 & 60 \\
\hline
\end{tabular}

Fonte: Sistematização da autora com base em uma amostra dos dados primários registrados nos BOs. (BAHIA, 2006-2008)

Prossegue-se a exposição mostrando o alto índice de violência praticada no âmbito domiciliar, cuja continuidade da situação nos anos que se seguiram à implantação da Delegacia, no dia 31 de julho de 2006, está ilustrada na Tabela 4, a seguir. Os filhos aparecem com o mais alto percentual entre os agressores $(26,3 \%)$, seguidos pelas filhas $(16,1 \%)$, que se equiparam ao percentual dos agressores que não se incluem entre aqueles com relações de parentesco ou de proximidade tipificados como "outros" $(16,6 \%)$. A violência contra a pessoa idosa configura-se tipicamente como familiar/doméstica, visto que os familiares são os que mais agridem e o domicílio é o lócus de maior ocorrência da agressão. 


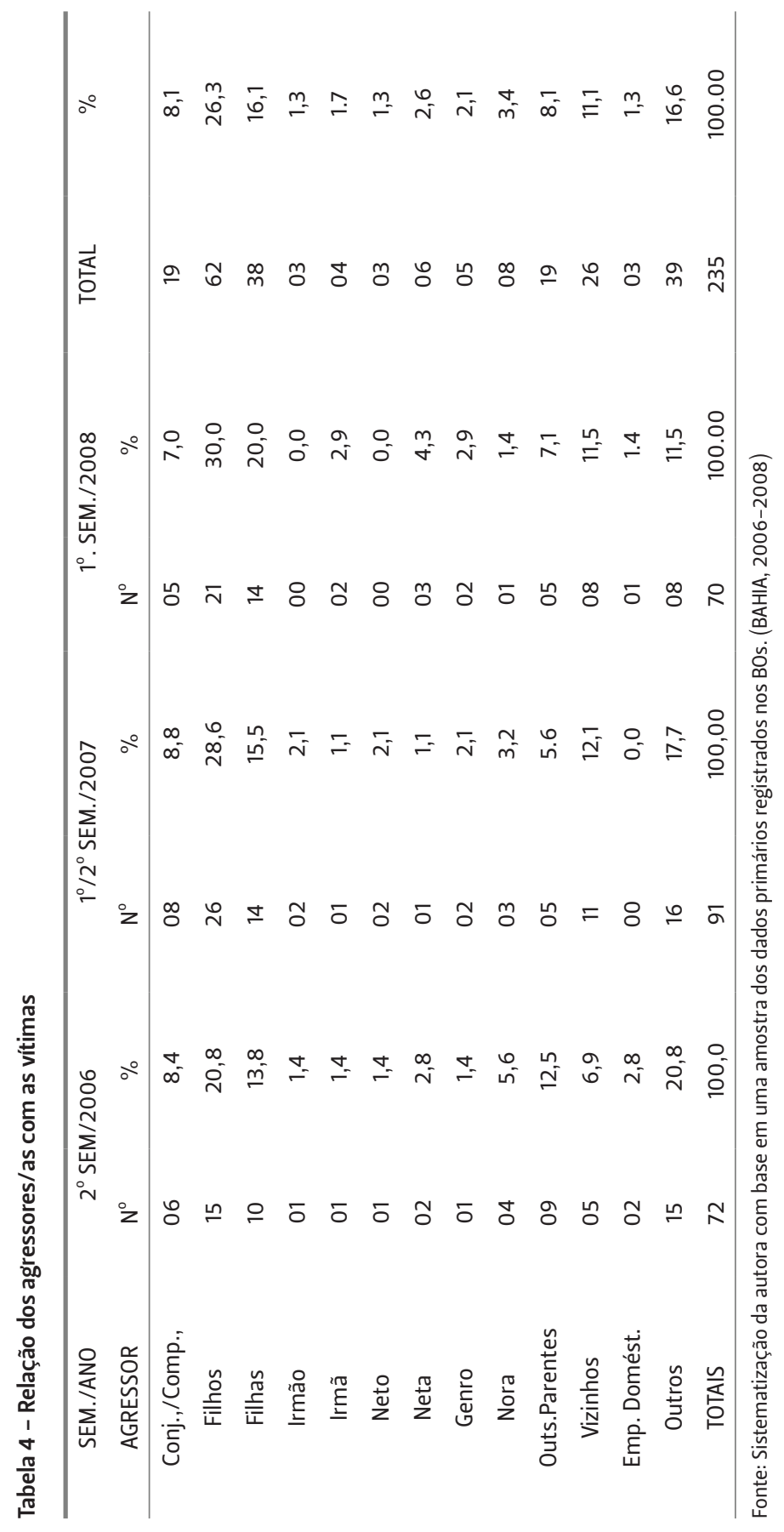


Realizado o cruzamento do número de filhos/as agressores/as com o número de pais agredidos, desdobrado, ambos, por sexo, é reforçada a tendência revelada em outros estudos do maior número de mulheres entre os agredidos. Mães vitimadas (65\%), para um total significativamente menor de pais na condição de vítimas $(35 \%)$. Reafirma-se também a tendência de que os homens compõem o maior contingente de agressores, agora na figura dos filhos $(65 \%)$ que têm suas mães como alvo principal, o que revela a dimensão de gênero entrecruzando a de geração. Vale ressaltar que, enquanto um menor número de mães são agredidas por filhas $(35 \%)$, esse percentual sobe quando se trata dos pais $(43 \%)$, o que revela que, proporcionalmente, as filhas agridem mais aos pais, explicitando a dimensão geracional desse tipo de violência.

Tabela 5 - Pais agredidos. Salvador

\begin{tabular}{ccccc}
\hline AGRESSOR & MÃE & $\%$ & PAl & $\%$ \\
\hline Filho & 42 & 65 & 20 & 57 \\
Filha & 23 & 35 & 15 & 43 \\
TOTAL & 65 & 100 & 35 & 100 \\
\hline
\end{tabular}

Fonte: Sistematização da autora com base em uma amostra dos dados primários registrados nos BOs. (BAHIA, 2006-2008)

Esses dados evidenciam que a realidade da violência contra a/o idosa/o na Região Metropolitana de Salvador, com relação às vitimas e aos agressores mais frequentes, não é diferente da de outros centros urbanos, revelada em pesquisas realizadas sob outras bases de informações e apresentadas na literatura sobre o tema. (PASINATO; CAMARANO; MACHADO, 2006; SOUZA et al., 2004) Os filhos e filhas juntos constituem o maior número entre os agressores, ademais vêm reafirmar o retrato que a literatura traz da família como um espaço de relações sociais contraditórias, lugar marcado por trocas afetivas e de solidariedade, mas também de opressão e violência, especialmente contra as mulhe- 
res e idosas/os. Sobre esse tema, Motta (1998) reafirma a posição tradicionalmente subalterna de um dos sexos e de uma das gerações na família tramada nas relações de poder, que se formatam na dominação/exploração de gênero e geração. Segue a discussão analisando essas relações na família contemporânea sob o impacto da maior longevidade, do retorno dos filhos/as descasados, desempregados ou ocupados com trabalho precarizado, não raro, trazendo companheiros/as e filhos/as para a casa dos pais, quase sempre mães velhas. Na análise dessa nova reconfiguração da família contemporânea, na qual enfoca a vida do idoso e da idosa, em número sempre crescente e, até por isso, cada vez mais coexistindo com outras gerações, a autora expõe a velha e sempre renovada contradição:

A família é também o lugar dos afetos radicais - onde as relações são quase simbióticas, as afeições mais doces e os embates entre os sexos/gêneros e as gerações podem ser mais dolorosos. Onde se encontram os modelos de sentimentos em estado mais depurado: os amores, as aceitações ilimitadas, as mais fundas solidariedades; ou as rejeições mais chocantes, os conflitos cotidianizados, ressentimentos 'inexplicáveis' e ódios. Explícitos ou recalcados. (MOTTA, 1998, p. 71)

Não é tarefa fácil combater esse tipo de crime, depara-se com muitas dificuldades. Por um lado, as vítimas, notadamente as mulheres mães, frequentemente solicitam a retirada da queixa ou não comparecem às audiências, conforme exposição da delegada: "Os violentados vão à Delegacia na hora da dor e depois não aparecem mais. Sequer aceitam ser interrogados. Não querem a continuidade do processo." A delegada também informa na entrevista citada que essas mulheres idosas vêm à delegacia em busca de um aconselhamento para os filhos/as agressores/as.

Há todo um trabalho de convencimento, visto que a vítima não permite a queixa, não permite a execução do 
trabalho destinado a protegê-las. Elas, muito mais as mulheres idosas, retiram, desistem da continuidade do processo. Vêm na hora da emoção, geralmente com um outro filho/a, como ela está sofrida, está doída, registra a queixa. Depois, passa uma noite, ela retorna, muitas vezes telefona, vem aqui fora do horário, dizendo 'oh! doutora, fui forçada a vim, mas não é bem assim'. Ou então, não fazem o exame de lesão de corpo de delito, porque a prova material desaparece.

Ademais, elas vêm em busca de uma instituição socioeducativa, mas não querem a instauração do processo para incriminá-los. Além do depoimento da delegada Márcia Telma, observei, nos BOs pesquisados, a desistência, por parte das vítimas majoritariamente mulheres, em dar prosseguimento à queixa para a instauração de inquérito. E quando as vítimas são questionadas sobre as motivações para não levarem o processo adiante, justificam que

[...] ele fez, mas é porque ele 'tava' bebendo, porque ele não é uma pessoa ruim não, doutora, é só de vez em quando, só [...]. A senhora faz isso mesmo, doutora, dá uma 'bronca' nele? Diga pra ele, doutora, que fui eu[a mãe] que pedi pra não fazer o processo, que eu 'tô' pedindo pra não fazer o processo, mas se ele voltar a me agredir, que a senhora vai fazer, vai processar ele. É como se a gente fosse os educadores, entendeu?(Márcia Telma Bithencourt, entrevista 24 de setembro de 2008)

Esse quadro, não incomum quando se trata de mulheres vítimas de violência, é descrito por Saffioti (2004) numa investigação sobre a violência de gênero, na qual assegura que a mulher procura uma Delegacia dos Direitos da Mulher (DDM) só para que fosse dado uma "prensa" em seu marido agressor, na expectativa de que a relação se estabeleça de forma diferente, sob as bases da 
harmonia. Concordo com a interpretação da autora e a tomo de empréstimo para explicar o comportamento ambíguo das mães idosas vítimas de violência, cuja relação com seus filhos/as, tanto quanto a de outras mulheres com seus maridos, está marcada pela afetividade e, por via de consequência, por múltiplas e recíprocas dependências, visto que "[...] as pessoas, sobretudo vinculadas por laços afetivos, dependem umas das outras. Não há, pois, para ninguém, total independência." (SAFFIOTI, 2004, p. 87) Não bastasse a ideologia de defesa da sagrada família a pressionar sua "guardiã" a segredar seus conflitos e não publicizar "sua culpa" pelo insucesso do grupo familiar sob sua responsabilidade.

Por outro lado, em Salvador, de acordo com os relatos da delegada titular Márcia Telma Bithencourt, desde o primeiro seminário já mencionado, ocasião em que a Delegacia de Atendimento ao Idoso estava com apenas 53 dias de funcionamento, vem-se insistindo na necessidade de criação de outras delegacias nos subúrbios para atendimento à pessoa idosa, visto que uma só delegacia para toda a RMS é incapaz de oferecer atendimento eficiente e eficaz. E mais, a delegacia não dispõe de uma estrutura para um atendimento adequado, considerando o grande volume de ocorrências.

Ela informa também, na mesma entrevista, que a Deati/BA tem todas as carências, como todas as outras delegacias. Não tem policiais em número suficiente, a única viatura, por exemplo, não tem serviço de rádio, nem armamento pesado, o que, segundo ela, é um tremendo risco. Não obstante todas essas dificuldades, inclusive quanto ao espaço físico, a Deati/BA priorizou dispor de um espaço que serve para a permanência da/o idosa/o agredido até que se viabilize a volta dela para casa em segurança, mediante o contato com outros familiares e/ou retirando o agressor da residência da vítima.

Ainda que convivendo com profundas carências a desafiar a criatividade da enxuta, mas aguerrida equipe de policiais, a Deati/ 
BA parecia caminhar pouco a pouco, em ritmo de consolidação, não fosse pela denúncia da delegada Márcia Telma no dia 17 de junho de 2009, por ocasião de outro Seminário sobre a violência contra o/a idoso/a, realizado pelo Fórum/Casa do Aposentado. Nesse evento, a delegada apelou ao movimento dos idosos/as, por intermédio do Fórum, para intervir, visando manter o atendimento diferenciado que os idosos/as recebem, retomando a luta em defesa da delegacia existente e pela instalação de outros serviços, visto que opiniões contrárias à manutenção da Delegacia Especializada do Idoso têm-se veiculado nos meios políticos. Em função disso, a Delegacia está sendo esvaziada, a equipe, que já era reduzida, apesar de muito comprometida, está sendo cada vez mais desfalcada com a retirada de policiais, sem sua imediata reposição.

Informa ainda, a delegada, que o acúmulo de trabalho para uma equipe que está minguando cada vez mais tem levado ao grande retardo nas marcações das audiências entre as partes, chegando a dois meses de atraso, contribuindo, muitas vezes, para a desistência do processo por parte da vítima e denuncia: "os idosos estão sendo disputados entre os filhos por causa da aposentadoria e não para serem bem cuidados, por amor a eles" (Delegada). A pobreza e o desemprego, consequência da violência social/estrutural, são definidores dessa situação de conflito intrafamiliar, visto que muitas vezes a aposentadoria da/o idosa/o é a única renda com a qual a família pode contar.

\section{Pontuando elementos a título de conclusão}

Já podemos aqui levantar alguns elementos, buscando concluir minha discussão neste trabalho. Há uma inexplicável dificuldade da proposta teórica-política feminista para perceber que também as idades/gerações constituem um dos eixos estruturantes da vida social. Ao manter-se fixada na sustentação categó- 
rica, como o faz Saffioti (1999, p. 142), "há três eixos principais que estruturam a sociedade brasileira; o gênero, a raça/etnia e a classe social", a teoria feminista vem estreitando o alcance da realidade vivida pelas mulheres em sua diversidade. A ausência dessa análise empobrece a luta política do feminismo, especialmente quando se omite de uma discussão cada vez mais acesa no atualíssimo contexto da reestruturação etária da sociedade, qual seja, a dimensão das políticas de proteção social. A discussão dessas políticas coloca as mulheres, comparadas aos homens, numa situação mais vulnerável, obrigadas a trabalhar muito mais tempo e arcar com um maior achatamento no valor de seus benefícios de aposentadoria. Tal discussão ganha novos significados na contemporaneidade marcada pelo crescente processo de envelhecimento da população, já mencionado acima, em que os circuitos entre as gerações assumem novas configurações. Nesses circuitos, as mulheres velhas são as principais figurantes, até porque são a maioria entre os mais velhos. Configura-se nessa situação uma profunda desvantagem para as mulheres quanto aos "pontos de chegada" (MOTTA, 2000) à idade avançada, em função das discriminações sofridas na trajetória de trabalho estruturada segundo o gênero. Essa discussão passa ao largo da teoria-política feminista, na medida em que as teóricas desse campo deixam escapar de suas agendas um dos elementos básicos da organização social em todas as sociedades conhecidas: a dimensão geracional.

A ausência da dimensão geracional na teoria e na ação empobrece a luta política feminista, na medida em que obstaculiza a análise de parte da realidade diversa vivida por elas, incluindo a da violência de gênero. A omissão desse fenômeno na análise feminista decorre da dificuldade que sua proposta teórico-política vem apresentando para perceber que as idades/gerações também constituem eixos estruturantes da vida social. 
Parece-me injustificável a total ausência nos estudos feministas dessa problemática da violência contra as pessoas de mais idade, que recai, sobretudo, sobre a mulher idosa. Nesse sentido, me alinho às observações de Motta (2009) quanto à não percepção do feminismo de que as mulheres idosas, tanto quanto as jovens e adultas plenas, são alvos privilegiados das mais diversas e concomitantes formas de violência, e que os agressores/as, geralmente mais jovens, são, sobretudo, homens - filhos, não raro netos -, mas também mulheres - filhas e noras, isto é, configurando-se no âmbito da família -, como vêm demonstrando os dados desta pesquisa, que reforçam informações de outros estudos sobre o tema: as relações geracionais podem dar conta de grande parte desse fenômeno, mas não o explica em sua integralidade. Do mesmo modo, enfocar a análise da violência contra as idosas no âmbito exclusivo das relações de gênero

[...] perde eficácia interpretativa e explicativa [...] A violência praticada [...] contra essas mulheres (maioria entre os idosos agredidos) [...] é expressão e consequência de vivências ou conflitos que se armam, basicamente, na esfera das relações intergeracionais. [...] uma violência que se dá em âmbito geracional, que ganha maior visibilidade por conta da situação de gênero: exerce-se em maioria sobre as mulheres, devido, primordialmente, à esperada 'fragilidade' feminina - física, afetiva e social. Ou analisada ao reverso: uma violência de gênero que se realiza majoritariamente no âmbito geracional. Por isso, é infugível a análise dos acontecimentos no contexto articulado dessas duas dimensões, de gênero e de gerações. (MOTTA, 2009, p. 8-9)

As teóricas feministas não conseguiram ainda perceber o imbricamento das dimensões de gênero e geração, significando diferencialmente a experiência de vida de indivíduos de diversas classes sociais e raças/etnias, como alcançado em Motta (2000, p. 10): “[...] há uma especificidade de gênero na situação de velhice, tanto quanto de idade e estágio geracional na condição de gêne- 
ro.” Tal postura exclui da análise teórica-feminista, e consequente ação política, as situações de vida de um contingente significativo de mulheres - as que conquistaram viver acima dos 60 .

\section{Referências}

AZEVEDO, E. Um palco de múltiplas vozes: a nova invenção dos/ as idosos/as em luta pela cidadania. 2010. $281 \mathrm{f}$. Tese (Doutorado em Ciências Sociais) - Faculdade de Filosofia e Ciências Humanas, Universidade Federal da Bahia, Salvador, 2010

BAHIA. [Boletins de Ocorrência]. Salvador: Delegacia Especial de Atendimento ao Idoso da Bahia, 2006-2008.

BOURDIEU, P. Questões de sociologia. Rio de Janeiro: Marco Zero. 1983. p. 112-121.

BRASIL. Construindo a Rede Nacional de Proteção e Defesa da Pessoa Idosa - RENADI. In: CONFERÊNCIA NACIONAL DOS DIREITOS DA PESSOA IDOSA, 1., Brasília Anais eletrônicos... Brasília, DF: Conselho Nacional dos Direitos do Idoso, 2006. Disponível em: $<$ http:// www.ipea.gov.br/participacao/images/pdfs/conferencias/Idosos/ regulamento_relatorio_1_conferencia_direitos_pessoa_idosa.pdf $>$. Acesso em: 13 ago. 2009.

BRASIL. Plano de ação internacional para o envelhecimento, Organização das Nações Unidas, 2002. Brasília, DF: Conselho Nacional dos Direitos do Idoso, 2003.

FEATHERSTONE, M. O curso da vida: corpo, cultura e o imaginário no processo de envelhecimento. Textos Didáticos, São Paulo, v. 1, n. 13, p. 49-71, 1994.

FORACCHI, M. M. A juventude na sociedade moderna. São Paulo: Pioneira, 1972.

FOUCAULT, M. Microfísica do poder. Rio de Janeiro: Graal, 1979.

LENOIR, R. Objeto sociológico e problema social. In: CHAMPAGNE, P. (Org.). Iniciação à prática sociológica. Petrópolis, RJ: Vozes, 1998. p. 59-106.

MINAYO, M. C. de S.; COIMBRA JUNIOR, Carlos E. A. Entre a liberdade e a dependência: reflexões sobre o fenômeno social do envelhecimento In: 
MINAYO, M. C. de S.; COIMBRA JUNIOR, C. E. A (Org.). Antropologia, saúde e envelhecimento. Rio de Janeiro: FIOCRUZ, 2002. p. 11-24.

MINAYO, M. C. de S. Violência contra idosos: relevância para um velho problema. Cad. Saúde Pública, Rio de Janeiro, v. 19, n. 3, p. 783-791, mar./jun. 2003.

MINAYO, M. C. de S. Violência contra idosos: o avesso do respeito à experiência e à sabedoria. 2.ed. Brasília: Secretaria Especial dos Direitos Humanos, 2005.

MOTTA, A. B. As dimensões de gênero e classe social na análise do envelhecimento. In: DEBERT, G. (Org.). Gênero em gerações. Campinas, SP: Núcleo de Estudos de Gênero Pagu, 1999.

MOTTA, A. B. Reinventando fases: a família do idoso. Caderno CRH/ UFBA, Salvador, v. 11, n. 29, p. 69-87, jul./dez. 1998.

MOTTA, A. B. Geração, a "diferença” do feminismo. Simpósio Internacional: o desafio da diferença: articulando gênero, raça e classe, 1., 2000, Salvador. Anais eletrônicos... Salvador: NEIM/UFBA, 2000. Disponível em: <http://www.desafio.ufba.br/gt7-001.html >. Acesso em: 18 maio 2015.

MOTTA, A. B. Violência contra as mulheres idosas - questão feminista ou questão de gênero? In: CONGRESSO DA ASSOCIAÇÃO DE ESTUDOS LATINO-AMERICANOS, Rio de Janeiro, 2009. Anais... Rio de Janeiro: LASA, 2009.

PASINATO, M. T.; CAMARANO, A. A.; MACHADO, L. Idosos vítimas de maus-tratos domésticos: estudo exploratório das informações dos serviços de denúncia. Texto para discussão, Rio de Janeiro n. 1200, 2006. Disponível em: < http://www.ipea.gov.br/portal/images/stories/ PDFs/TDs/td_1200.pdf >. Acesso em: 18 maio 2015.

RIFIOTIS, T. O ciclo completado: a dinâmica dos sistemas etários em sociedades negro-africanas. In: BARROS, M. M.(Org.). Velhice ou terceira idade? estudos antropológicos sobre identidade, memória e política. Rio de Janeiro: FGV, 2000. p. 85-111.

SAFFIOTI, H. I. B. Gênero e patriarcado: violência contra mulheres. In: VENTURI, G. et al. (Org.). A mulher brasileira nos espaços público e privado. São Paulo: Fundação Perseu Abramo, 2004. p. 43-59. 
SAFFIOTI, H. I. B. O estatuto teórico da violência de gênero. In: SANTOS, J. V. T. dos (Org.).Violência no tempo da globalização. São Paulo: Hucitec, 1999. p. 142-163.

SOUZA, A. S. et al. Fatores de risco de maus-tratos ao idoso na relação idoso/ cuidador em convivência intra-familiar. Textos sobre Envelhecimento, Rio de Janeiro, v. 7, n. 2, p. 57-76, 2004.

YOUNG, M. I. La justicia y la política de la diferencia. Madrid: Ed. Cátedra, 2000. 


\section{MÚSICA E VIOLÊNCIA narrativas do divino e feminicídio}

Laila Andressa Rosa

Este artigo nasce de algumas questões percebidas no contexto religioso da jurema sagrada, tema da minha tese de doutorado (ROSA, 2009a), que se debruçou sobre as narrativas humanas e divinas de mulheres negras e de suas entidades espirituais femininas, bem como dos repertórios musicais sagrados. Em relação a algumas entidades em particular, a violência consiste numa tônica de suas trajetórias e narrativas musicais. Para as entidades masculinas, tais quais exus e mestres, a violência policial e das ruas está em grande parte presente. Para as entidades femininas, a violência de gênero e o feminicídio são experiências constantemente narradas.

Considero esta também uma retomada sobre a importante articulação entre música e violência, como proposta por Ana Maria Ochoa Gaultier (2006), sobretudo na perspectiva da etnomusicologia, que, aqui no Brasil, quando abordada, tem se centrado, majoritariamente, na questão da classe social, do racismo e do etnocídio indígena, questões sem dúvida alguma de grande relevân- 
cia e pertinência. Contudo, me incomodava (e ainda incomoda) o fato de que a dimensão de gênero das violências seja ainda invisibilizada no universo dos estudos e militâncias sobre música no Brasil.

Esse é um tema muito caro a mim mesma, que fui vítima de violência doméstica e de abuso sexual na infância e pré-adolescência e que pude descobrir na música um território especial de descoberta e de sobrevivência. Ao longo da minha trajetória de mulher branca e pobre de periferia de Recife, Pernambuco, e depois Carpina, interior do estado, sendo oriunda de escola pública e a primeira da família a ingressar e concluir um curso universitário, com direito a mestrado e doutorado, experimentei a música assim como tantas outras mulheres: para além da afetividade. Da música desde sempre floresceram espaços de revolta, denúncia e enfrentamentos ao racismo, ao sexismo, à lesbo e transfobia, e, igualmente, espaços de renascimento e de crescimento humano.

Ainda que tenha abordado a questão da violência na tese, a ideia de aprofundar o debate sobre tais repertórios e experiências a partir da perspectiva do feminicídio só emergiu posteriormente. ${ }^{1}$ A temática da violência estava até então adormecida durante vários anos pelas minhas descobertas musicais. Para minha surpresa, a mesma emergiu anos depois onde eu menos esperava, no contexto sagrado da jurema, religião afro-indígena, que, assumindo como tema da tese, passei a desenvolver grande apreço e respeito. Mas não foi assim desde o início. Inicialmente, pensei em abandonar o tema ao constatar o grau de violência simbólica e, por vezes, até física que está presente nas performances de determinadas entidades e também narradas por seus pontos cantados. $\mathrm{E}$ ao avaliar as minhas limitações para compreender as complexi-

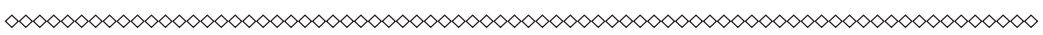

1 Agradeço à prof ${ }^{a}$ Rita Laura Segato pelas preciosas sugestões sobre a perspectiva do feminicídio no contexto da jurema sagrada quando esteve na minha banca de doutorado e, posteriormente, num café da tarde, durante o Seminário Internacional Fazendo Gênero, de 2010. Igualmente, agradeço à prof ${ }^{a}$ Cecília Sardenberg nos debates no Núcleo de Estudos Interdisciplinares sobre a Mulher (NEIM) sobre a questão da violência simbólica, e ao meu querido amigo, o prof. Clebemilton Nascimento, parceiro de boas empreitadas acadêmico-musicais. 
dades presentes na jurema sagrada, retrocedi. Felizmente. Pois, sem dúvida, essas histórias de algum modo dialogam também com a minha própria história. São histórias de muitas Marias, Luziaras, Ritinhas, Lailas que, infelizmente, ainda que de maneira muito distinta, se fazem realidade e que, justamente por essa razão, precisam ser contadas e recontadas para que deixem de ser naturalizadas, negligenciadas e silenciadas.

Para construir minha narrativa juntamente com as narrativas da jurema sagrada, dividi o artigo em quatro partes, que chamo de "atos":

1. Sobre música e violência, onde faço uma revisão bibliográfica sobre o tema, iniciando pelo conceito de feminicídio, femigenocídio e transfeminicídio para chegar propriamente no debate sobre música e violência, que inclui o contexto baiano e o Projeto de Lei n. 19.237/11, sancionado em 2012 e que proíbe a contratação por parte do Estado de bandas que cantem músicas misóginas, racistas e homofóbicas, o que gerou e ainda gera grande polêmica no meio artístico e intelectual baiano;

2. Das narrativas subalternas e contraventoras, onde entram os diversos e complexos idiomas que constituem a dinâmica da jurema, enquanto religião, de se configurar como um “outro periférico" em relação ao contexto hegemônico religioso nacional;

3. Luziara, Ritinha e o feminicídio como categoria musical, quando as entidades femininas da jurema sagrada trazem suas narrativas musicais de enfrentamento ao racismo, ao sexismo e ao feminicídio, e é também onde analiso um ponto cantado das mestras Luziara e Ritinha;

4. Música, políticas sexuais e violência, quando discuto sobre a questão das sexualidades e a ruptura com os padrões so- 
ciais hegemônicos da heteronormatividade como uma experiência sagrada legítima e possível no contexto religioso da jurema.

$E$ antes de prosseguir, me apresento como uma mulher de axé, tendo me tornado filha de santo do Terreiro Xambá (Olinda-PE), que por mais de 10 anos me acolheu como pesquisadora. Logo, inicio este debate pedindo licença às entidades espirituais da jurema sagrada, às madrinhas e aos padrinhos de jurema e todas as juremeiras e juremeiros do Terreiro Xambá, minhas e meus ancestrais.

Salve a jurema sagrada! Salve as mestras! Mojubá!

\section{Ato I: Música e violência}

Historicamente, há uma tendência de se apontar para a violência como produto das desigualdades sociais no Brasil, privilegiando o conceito de classe social. Por outro lado, a partir do recorte de gênero, os estudos feministas no Brasil têm mostrado como mulheres e homens são vítimas de diferentes tipos de violência, sendo a exploração sexual e doméstica realidades que muitas mulheres enfrentam. O Movimento Negro, tanto no Brasil como nos EUA, denunciou o racismo institucional e sua face gendrada e racial de produção de violência, sobretudo policial. A pensadora e ativista negra estadunidense Angela Davis (1998) mostra em seus estudos como homens jovens negros configuram a grande população carcerária como vítimas de uma política eugenista de exclusão da população negra e da negação dos seus direitos civis nos EUA, e sabemos que o mesmo modelo é reproduzido em solo brasileiro. Finalmente, feministas negras e indígenas latino-americanas propõem a articulação entre raça/etnia, gênero e classe social para compreender a tripla opressão das desigualdades sociorraciais e de gênero da qual mulheres negras e indígenas são 
vítimas. Sobre as desigualdades sociorraciais e de gênero, Antônia dos Santos Garcia (2010) declara que:

Sexismo, racismo e classismo são construções sociais milenares e universais, mas ao longo de séculos ficou subsumido na categoria de classes sociais. A centralidade nesta categoria de análise tem invizibilizado a natureza de outras desigualdades, ou seja, as desigualdades de gênero e raça, não se restringem às classes sociais. Contudo, nas últimas décadas houve questionamentos desse sujeito único como explicativo das condições desiguais vividas pelas maiorias negras e femininas em todas as sociedades. Assim, para enfrentar os desafios do século XXI, século da reparação, é crucial que as Ciencias Sociais contribuam para dar maior visibilidade às desigualdades de gênero e raça, já que as políticas universalistas não têm reduzido os abismos raciais e de gênero. (GARCIA, 2010, p. 1)

É a partir do recorte de gênero que os estudos feministas no Brasil têm mostrado como mulheres e homens podem ser vítimas de específicos tipos de violência. Mulheres são vítimas de diversas violências, tais quais o racismo, o sexismo, a lesbofobia, a transfobia, a exploração e violência sexual e doméstica, dentre outras. A Lei Maria da Penha consiste numa importante resposta e conquista ao combate da violência de gênero, pois, dentre importantes ações, "tipifica e define a violência doméstica e familiar contra a mulher.” (BRASIL, 2006)

Feministas latino-americanas adotaram o conceito de "feminicídio”, relativo ao homicídio feminino. Segundo Marcela Lagarde (2004, p. 7, tradução nossa):

O feminicidio é genocídio contras mulheres e acontece quando as condições históricas geram práticas sociais que permitem atentados contra a integridade, a saúde, a liberdade e a vida das mulheres. O feminicidio concorre no seu tempo e espaço, danos contra mulheres realizados por conhecidos e desconhecidos, por violentos, violadores e assassinos individuais e grupais, ocasionais ou profissionais, que conduzem a morte cruel de algumas 
das vítimas. Nem todos os crimes são combinados ou realizados por assassinos seriais: existem seriais e individuais, alguns são cometidos por conhecidos: parceiros, parentes, namorados, esposos, acompanhantes, familiares, visitas, colegas e companheiros de trabalho; também são perpetrados por desconhecidos e anônimos, e por grupos mafiosos e delinquentes ligados a modos de vida violentos e criminais. Sem dúvida, todos têm em comum que as mulheres usáveis, prescindíveis, maltratáveis e descartáveis. E, desde logo, todos coincidem infinita crueldade e são, na verdade, crimes de ódio contras as mulheres. ${ }^{2}$

Mais recentemente, Rita Laura Segato (2010) vai ressaltar como o termo "femi-genocídio" é importante, por possuir um status jurídico de grande amplitude, nos termos de uma sensibilização política internacional a partir da perspectiva do genocídio, que é considerado como crime internacional contra os direitos humanos.

Já no Brasil, somente nesse ano que conquistamos a lei sancionada pela presidenta Dilma Rousseff, que prevê o feminicídio como crime hediondo, correspondendo ao crime "contra a mulher por razões da condição de sexo feminino.” (BRASIL, 2015a, b) Contudo, há ainda a problemática da inclusão das mulheres trans, vítimas do transfeminicídio, termo proposto pela socióloga Berenice Bento (2014, p. 1) para "nomear os assassinatos cometidos contra a população trans [...], reforçando que a motivação da violência advém do gênero.” A autora complementa que, assim como no feminicídio, a problemática do transfeminicídio está diretamente ligada à desvalorização do feminino:

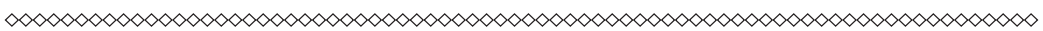

2 El feminicidio es el genocidio contra mujeres y sucede cuando las condiciones históricas generan prácticas sociales que permiten atentados contra la integridad, la salud, las libertades y la vida de las mujeres. En el feminicidio concurren en tiempo y espacio, daños contra mujeres realizados por conocidos y desconocidos, por violentos, violadores y asesinos individuales y grupales, ocasionales o profesionales, que conducen a la muerte cruel de algunas de las víctimas. No todos los crímenes son concertados o realizados por asesinos seriales: los hay seriales e individuales, algunos son cometidos por conocidos: parejas, parientes, novios, esposos, acompañantes, familiares, visitas, colegas y compañeros de trabajo; también son perpetrados por desconocidos y anónimos, y por grupos mafiosos de delincuentes ligados a modos de vida violentos y criminales. Sin embargo, todos tienen en común que las mujeres son usables, prescindibles, maltratables y deshechables. Y, desde luego, todos coinciden en su infinita crueldad y son, de hecho, crímenes de odio contra las mujeres. 
Se o feminino representa aquilo que é desvalorizado socialmente, quando este feminino é encarnado em corpos que nasceram com pênis, há um transbordamento da consciência coletiva que é estruturada na crença de que a identidade de gênero é uma expressão do desejo dos cromossomas e dos hormônios. O que este transbordamento significa? Que não existe aparato conceitual, linguístico que justifica a existência das pessoas trans. Mesmo entre os gays, é notório que a violência mais cruenta é cometida contra aqueles que performatizam uma estilística corporal mais próxima ao feminino. Portanto, há algo de poluidor e contaminador no feminino (com diversos graus de exclusão) que precisam ser melhor explorados. (BENTO, 2014, p. 1)

Inicialmente, o propósito deste artigo se detinha ao conceito de feminicídio ou femigenodício, pensando sobre a violação específica contra corpos femininos que é narrada em cantos sagrados e performatizados por entidades espirituais da religião afro-indígena "jurema”. (ROSA, 2009a) Após a leitura da autora Berenice Bento, me parece que o conceito de transfeminicídio soma à realidade da jurema sagrada, onde a experiência do transe ou incorporação elabora as performances das entidades espirituais. Estas informam discursos, materializações corpóreas e musicais, tratando-se também de narrativas biográficas de mulheres negras, indígenas e afro-indígenas que se entrelaçam também às mulheres trans, visto que estas são também adeptas da religião e se identificam com tais narrativas em seus cotidianos.

Pode soar paradoxal relacionar música à violência. Contudo, não é o que nos mostram os diversos estudos sobre música em contextos de conflito e de violência. Somente para citar alguns, temos o caso de música como ferramenta de tortura, abordada por Suzanne Cusick (2006, p. 5) no seu artigo "Música como tortura/ música como arma”, onde há a utilização de técnicas de tortura sem o uso direto da violência (física) em contextos de guerra, forçando prisioneiros a ouvir a mesma música por dias a fio em processos interrogatórios traumatizantes e violentos, de modo que 
a pessoa imediatamente associará a música ao momento da violência sofrida, tornando-a por si só a própria violência. ${ }^{3}$ Samuel Araújo Junior e colaboradoras/es (2006, p. 1) ressaltam que:

Diante de ideologias de arte burguesa e percepções do sublime que usualmente lhes correspondem, discorrer sobre música e violência certamente sugere um contrassenso. Afinal, em tal perspectiva, o que poderia haver, além da música, de mais exemplar da não-violência, de sociabilidade pacífica e, portanto, de seu presumido reconhecimento universal como valor positivo?

Bruce Johnson e Martin Cloonan (2009) também destacam como, na maioria dos casos, somente os aspectos positivos da música são evidenciados, carecendo de estudos sobre as diversas paisagens sonoras de violência. Nestas, incluímos a racialização e a hipersexualização da figura feminina, como bem narra Liv Sovik (2009) ao analisar a internacionalizada "Garota de Ipanema", dentre outros ricos exemplos da música popular brasileira. (SOVIK, 2009)

Em relação às memórias musicais da violência, Silent Jane (2006), pseudônimo adotado pela autora do artigo, narra a trilha sonora e o campo das sensações (sinestesia) de sua experiência de ter sofrido abuso sexual na infância. E Ana Ochoa Gaultier (2006, p. 1) destaca outras questões pertinentes sobre a relação, ou "áreas de questionamento inter-relacionadas”, entre música e violência, por exemplo, que formas tomam as diferentes violências e vivências de adversidade e sofrimento social para pensar o social e polí-

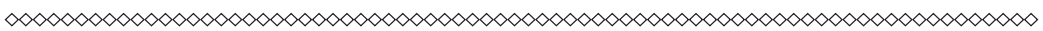

3 Esse mesmo procedimento também é comumente mencionado em depoimentos de militantes de esquerda durante o período da Ditadura Militar no Brasil e América Latina, por exemplo, como retratado pelo filme A morte e a donzela, de Roman Polanski (1994), em que a protagonista havia sido torturada e estuprada diversas vezes por um militar sádico, durante a ditadura militar, ouvindo sempre a mesma música: "0 quarteto de cordas n. 14", do compositor alemão Franz Schubert (1824), conhecida popularmente como "A morte e a donzela". Ou seja, notadamente o título do quarteto de Schubert, que sugere o título do filme e é trilha para o enredo, cujo roteiro se inspira na peça de teatro do chileno exilado da ditadura de Pinochet, Ariel Dorfman. (A MORTE..., 1994; QUERTETO..., 2015) 
tico? Como se dá o impacto sobre adversidades pessoais, sociais e políticas nas práticas musicais, nas maneiras como imaginamos o musical e na materialidade da música?

No contexto baiano, Clebemilton Nascimento (2009, p. 157159) nos mostra minuciosamente como, em pleno século XXI, com todas as conquistas feministas por direitos civis e enfrentamentos ao racismo, ao sexismo, à lesbofobia e à transfobia, a tônica das letras das canções dos pagodes baianos ainda é de uma representação feminina em geral desqualificada e diminuída sob a ótica sexista dos seus compositores. Nesse discurso majoritariamente masculino, as mulheres protagonizam enquanto "cachorras", "piriguetes", "metralhadas", "pomba-sujas" ou "frutas". Embora o autor tenha o cuidado de nos apresentar o caráter multifacetado desse discurso, sobretudo em relação à figura da "piriguete", reconhece, ao final, que o mesmo desqualifica e marginaliza o corpo feminino fora do padrão hegemônico de beleza.

Ainda sobre o pagode baiano, Cecília Sardenberg 4 (2011) fala sobre a violência simbólica de gênero e a importância do Projeto de Lei estadual n. 19.237/11, que ficou conhecido como "Lei antibaixaria”, de autoria da Deputada Luiza Maia (PT), cuja aprovação pela Assembleia Legislativa da Bahia, em 27 de março de 2012, ainda levanta muitas polêmicas. ${ }^{5}$ Segundo Natália Cancian (2012):

Conhecido como a 'Lei Antibaixaria', o texto proíbe que eventos públicos, financiados pelo governo, contratem artistas

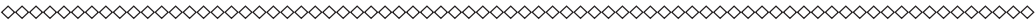

4 Antropóloga feminista, prof $^{\mathrm{a}} \mathrm{dr}^{\mathrm{a}}$ da Universidade Federal da Bahia (UFBA), cofundadora do Núcleo de Estudos Interdisciplinares de Gênero (NEIM/UFBA) e uma das coordenadoras nacionais do Observatório de Monitoramento da Lei Maria da Penha (Observe), que funciona desde 2007.

5 A forma como a lei ficou conhecida já lhes confere um caráter classista e também racista, denunciado por autores como Simon Frith (2004) ao falar sobre a ideia de uma suposta "Má Música: a música que amamos odiar". Felipe Trotta (2008) também discute sobre gosto musical e a questão da festa e da sexualidade nos shows de bandas de forró eletrônico, chamadas pejorativamente como "Forró de plástico". Por outro lado, considerando a lei em si, o fato de que haja um repertório explicitamente misógino e racista é inquestionável e, para nós feministas, sua aprovação representa uma conquista, visto que a lei se restringe apenas à contratação por parte do governo estadual, o que não se configura como censura. 
que "desvalorizem, incentivem a violência ou exponham as mulheres à situação de constrangimento" em suas músicas. Homossexuais também são mencionados como sujeitos de violência nas canções.

Cecília Sardenberg (2011, p. 3) nos alerta que, diferentemente do enfretamento da violência física contra mulher, que muito ganhou com a Lei Maria da Penha, a violência simbólica é mais eficaz justamente por ser menos materializada e, portanto, de cunho psicológico, que afeta, sobretudo, a autoestima das mulheres, sendo:

[...] indubitavelmente, uma das violências de gênero mais difíceis de detectarmos, analisarmos e, por isso mesmo, combatermos. Talvez até mesmo porque o 'bombardeio' é tanto, de todos os lados, que acabamos ficando anestesiadas, inertes, impassíveis, incapazes de percebê-la, bem como o seu poder destruidor. Na verdade, o mundo simbólico aparece como um grande quebra- cabeça a ser decifrado, difícil de abordar, vez que, como no caso das metáforas, ele se processa através de um encadeamento e superposição de símbolos e seus significados, ou de associações, transposições, oposições e deslocamentos. Destrinchar esses processos é muitas vezes adentrar num labirinto, correndo atrás de um novelo que torce, retorce, rola, enrola e dá nós, difíceis de serem desatados. Por isso mesmo, a violência simbólica é sutil, mascarada, disfarçada e, assim, bastante eficaz.

Essas últimas abordagens que consideram o recorte de gênero e suas especificidades étnico-raciais, de classe e sexualidade caem "como uma luva" para pensar sobre o contexto musical da religião afro-indígena jurema, acrescentando a temática da violência contra a mulher, o feminicídio e também o transfeminicídio à discussão. Esse contexto pode ser compreendido como um extenso campo das trajetórias históricas de entidades espirituais que sofreram violência sexual, dentre diversos outros tipos de violência, quando eram humanas. A partir daí, uma "outra" história de mulheres silenciadas pela violência emerge. 


\section{Ato II: Das narrativas subalternas e contraventoras}

No contexto religioso da jurema, humano e divino muitas vezes se confundem. Os pontos cantados consistem também de narrativas autobiográficas das entidades religiosas. Por outro lado, o povo de santo tem a oralidade como narrativa complementar ao que não é explicitamente dito sobre as entidades espirituais, suas trajetórias. Nessas trajetórias há diferentes discursos, a que chamo de "idiomas." (ROSA, 2009a, b) São eles:

1. Idiomas de pureza - princípio teológico que rege a relação entre o culto aos orixás e a religião afro-indígena jurema. Nessa última, existem dois lados ou correntes espirituais antagônicos que são compostos pelo lado da esquerda (pombagiras ${ }^{6}$ e exus/mestras e mestres) e da direita (caboclas e caboclos/pretas-velhas e pretos-velhos). Há ainda uma corrente espiritual que pode ser compreendida como "interseccional", ou seja, tanto pode atuar na direita como na esquerda, sendo, no entanto, considerada mais "leve" e também mais rara de encontrar nas casas de jurema: a corrente cigana;

2. Idiomas de morte - como as entidades deixaram de ser humanas para se tornarem entidades espirituais. Estas podem ter sido "passadas" (assassinadas), "encantadas" (consideradas seres de grande evolução espiritual que não morre-

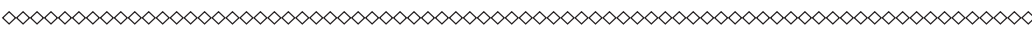

6 A grafia do nome desta poderosa entidade feminina pode ser encontrada na literatura também como Pombajira, Bombogira, Pomba-Gira ou ainda Pomba Gira, todas sendo consideradas corretas. Neste artigo, assim como na minha tese de doutorado (ROSA, 2009), optei por utilizar o nome Pombagira, visto que é mais recorrente na literatura especializada sobre religiões afro-brasileiras como encontramos em Reginaldo Prandi, citando Monique Augras: "Na língua ritual dos candomblés angola (de tradição banto), o nome de Exu é Bongbogirá. Certamente Pombagira (Pomba Gira) é uma corruptela de Bongbogirá, e esse nome acabou por se restringir à qualidade feminina de Exu." (AUGRAS, 1989 apud PRANDI, 1996, p. 139) 
ram fisicamente como qualquer outro ser humano, mas se "encantaram" nas matas);

3. Idiomas de feminino - os diferentes arquétipos de feminino conforme sua geração, que estão presentes e vão desde "singeleza infantil" indígena à jovialidade sensual de ciganas ou supersexualizadas mestras e pombagiras e à velhice e sabedoria das pretas-velhas;

4. Idiomas de sexo (políticas sexuais) - estão relacionados ao tópico anterior. São performatizados e considerados como referências para o cotidiano da comunidade.

Parte das entidades femininas foram pessoas que em vida tiveram seu lugar de subalternidade ao extremo, sendo consideradas como sujeitos "abjetos" da sociedade: formam um panteão religioso que vai desde singelas caboclinhas crianças às sábias e sérias pretas-velhas, até alguns mestres que foram ladrões envolvidos com jogo e problemas com a polícia às mestras e pombagiras, comerciantes, prostitutas e cafetinas. Dentro dessa esfera, estão as temáticas da violência, do sexismo e do feminicídio, narradas pelos cantos das entidades femininas que viveram provavelmente no início do século passado, as mestras e também as pombagiras.

Embora os cantos das entidades narrem diversos aspectos de suas vidas passadas, as narrativas do povo de santo atuam enquanto narrativas complementares fundamentais para compreender as trajetórias históricas dessas mulheres que se divinizaram em espírito para retornar para trabalhar espiritualmente. Ambas as narrativas (humana e divina) consistem em revelações sobre o que as entidades representam, por elas mesmas, e como as/os juremeiras/os veem e compreendem esses sujeitos-entidades espirituais. Neste sentido, podemos considerar que tanto as entidades quanto as pessoas que recorrem cotidianamente às mesmas estabelecem relações afetivas e espirituais num panorama de subalternidade e 
contravenção, visto que a jurema enquanto religião é historicamente estigmatizada como "catimbó" e "baixa magia".

Rita Laura Segato (2002) vai chamar esse processo de exclusão e exotização de produção contínua das "alteridades históricas" pelo contexto nacional hegemônico. Segundo a autora, seriam os sujeitos que elaboram outras vias para narrar suas histórias, trajetórias e experiências, que compõem epistemologias particulares e complexas e que foram negligenciadas por uma história oficial branca que não os contempla em seu projeto hegemônico, homogenizante e pseudoglobalizante:

As alteridades históricas são os grupos sociais cuja maneira de ser 'outros' no contexto da sociedade nacional se deriva dessa história e é parte dessa formação específica. As formas de alteridade e desigualdade histórica próprias de um contexto não podem ser se não falsamente transplantadas a outro contexto nacional, e os vínculos entre elas não podem estabelecer-se sem a mediação necessária, sob risco de cair num mal entendido planetário ou, o que é pior, que imponhamos um regime de clivagens próprios de um contexto específico a todo o mundo - o que não seria, nem mais nem menos, outra coisa que subordinar o valor da diversidade, hoje emergente, ao projeto homogeneizador da globalização. Em outras palavras, é a partir do horizonte de sentido de nação que se percebem as construções da diferença. ${ }^{7}$ (SEGATO, 2002, p. 115, tradução nossa)

O conceito de alteridade histórica se configura politicamente como uma categoria subalterna, e é desse lugar de subalternidade que os sujeitos se expressam, mesmo que não estejam autorizados para fazê-lo. "Pode o subalterno falar?" provoca Gayatri Spivak

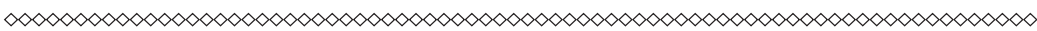

7 Las 'alteridades históricas' son los grupos social es cuya manera de ser 'otros' enel contexto de la sociedad nacional se deriva de esa historia y es parte de esa formación específica. Las formas de alteridad y desigualdad histórica propias de un contexto no pueden ser sino falazmente transplantadas a otro contexto nacional, y los vínculos entre ellas no pueden establecerse sines a mediación necesaria, a riesgo de caer en un mal entendido planetario o, lo que es peor, que impongamos un régimen de clivajes propios de un contexto específico a todo el mundo -lo que no sería, ni más ni menos, otra cosa que subordinar el valor de la diversidad, hoy emergente, al proyecto homogeneizador de la g'obalización. En otras palabras, es a partir del horizonte de sentido de la nación que se perciben las construcciones de la diferencia. 
(2010), a partir da denúncia de que a sociedade hegemônica se sobrepõe enquanto centralidade epistemológica e política única. É a partir desse lugar de suposta centralidade que se cria a categoria "outro".

Podemos afirmar que esses sujeitos da jurema falam de um lugar de subalternidade epistemológica e política por várias razões que estiveram presentes no passado e ainda se fazem presentes na atualidade: ontem, por manterem uma tradição de descendentes de indígenas e africanos escravizados, marginalizados, silenciados historicamente através da violência e dos racismos institucionais; hoje, por enfrentarem cotidianamente, na maioria dos casos, o racismo e o sexismo, como é possível observar no contexto do Terreiro Xambá, tombado em 2006 pela Fundação Palmares do $3^{\circ}$ Quilombo Urbano do Brasil. Por serem, na atualidade, esses sujeitos em sua maioria negra e afro-indígena e, por último, por se ter no topo da liderança religiosa, em sua maioria, mulheres negras, filhas de parteiras, rezadeiras, cabeleireiras, costureiras, líderes comunitárias, mães de santo etc. Ou seja, estamos retomando a fala de Jurema Werneck sobre mulheres cujos "passos vêm de longe" (WERNECK, 2006) dentro dessa história de violência, de superação e de matrilinearidade, onde a participação dessas mulheres pode ser lida até a atualidade como:

\footnotetext{
Porta-vozes essenciais de uma diversidade centrada na contribuição africana. Aqui, a presença da mulher negra vem a significar uma ação que se integra a um conjunto de iniciativas já em desenvolvimento, com o objetivo de reverter esquemas de subordinação. (WERNECK, 2006, p. 10)
}

Esse entrecruzamento de histórias reverte esquemas de subordinação, na medida em que o mesmo se apresenta e quebra com o silêncio imposto pelas ditaduras que proibiam as práticas religiosas de matrizes africanas e afro-indígenas, assim como na inquisição com as bruxas medievais, o que chamei na minha tese 
como "as donas de uma ciência ilegítima." (ROSA, 2009) E é desse contexto que se configuram as narrativas das entidades mestras.

\section{Ato III: Luziara, Ritinha e o feminicídio como categoria musical}

Ponto cantado é a música cantada para as entidades da jurema, ou seja, a representação sonora especialmente vocalizada das entidades que são reconhecidas e cantadas também pelo povo de santo. Sobre o contexto do xangô pernambucano, cuja relação com o musical e o sagrado se dá de forma semelhante, Rita Segato (1999b, p. 242-243) explica: ${ }^{8}$

Os membros do culto dirigem-se, por intermédio de cada repertório, a uma entidade concebida como habitante de uma dimensão supra-ordenada e que, em dado momento do canto do repertório, deve tornar-se uma presença real por meio da música. Isso significa que o temperamento de cada entidade deve ser de alguma forma expresso em música e que cada performance musical consiste numa busca coletiva, da experiência de contato concreto com cada modelo de personalidade.

Para compreender os pontos cantados, é importante compreender também o fato de que cada entidade possui seu próprio repertório musical, o que lhes confere um caráter individualizante também em termos sonoros. O mesmo se reflete nos aspectos vocais. Cada entidade possui sua performance vocal específica, que é definida a partir dos aspectos de gênero, étnico-racial, de classe, das sexualidades e geracionais.

Susan Mcclary (1994, p. 79, tradução nossa) destaca a importância de teorias de música que reúnam perspectivas dos estudos de cultura e da crítica feminista para "uma compreensão ampla

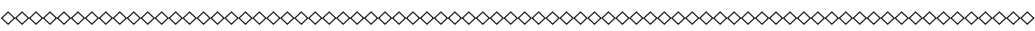

8 Diferentemente dos pontos riscados que são as representações gráficas das mesmas, mas que já não foram encontradas no contexto pesquisado. 
da música." Elas tratariam das representações e construções de gênero, subjetividade, desejo, etnicidade, corporalidade etc. Já Margaret Sarkissian (1992, p. 338-42) aponta alguns temas recorrentes levantados por estudos feministas no campo dos estudos sobre música:

1. Sobre a importância da performance musical no processo de socialização, tanto expressando como moldando a ordem social;

2. Segregação dos mundos musicais femininos e masculinos como parte da uma tendência de oposição binária;

3. Estudos dos comportamentos musicais como indicador de relações de poder baseadas em gênero;

4. Estudos de música e gênero sobre estilos vocais;

5. Público e privado e comportamento musical, diferentes domínios musicais;

6. Relações de gênero entre o real e o sobrenatural;

7. Dicotomias natureza e cultura;

8. Relações assimétricas de poder.

Minha pesquisa sobre as entidades femininas da jurema, seus repertórios musicais, suas performances em diálogo com o contexto religioso e suas relações de gênero e de poder se inspira nos tópicos citados acima, considerando, além do gênero, raça e etnia, classe, sexualidades e geração como importantes ferramentas analíticas e interseccionais que devem ser observadas:

1. Gênero - das representações de feminino, do transgênero, que pode ser vivenciado no transe, das relações de poder e assimetrias entre homens e mulheres na religião;

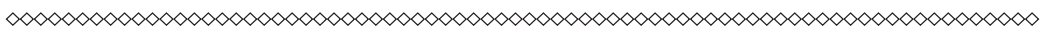

9 In short, I would like to see a future in which theorists, students of culture, and feminist critics can all collaborate in the greater understanding of music. We need not be a todds. 
2. Raça e etnia - das identidades étnico-raciais que marcam o culto da jurema e suas entidades que são consideradas negras, indígenas e/ou mestiças. Cada categoria vai se expressar de forma específica tanto na fala como musicalmente, onde as possibilidades de inversão são várias: uma pessoa negra pode se tornar uma entidade indígena, uma pessoa branca pode se tornar uma preta-velha etc.;

3. Classe social - da questão econômica e social que situa os sujeitos da jurema, grande maioria mulheres negras de classe econômica de menor poder aquisitivo, e também das suas entidades. O transe representa um veículo de inversão onde uma mulher ou mesmo um homem negro e pobre pode ser uma pombagira, com acesso a artigos finos e caros que não fazem parte do seu cotidiano; uma mulher branca $\mathrm{e}$ de classe média alta pode se tornar uma preta-velha escravizada e com recursos financeiros mínimos;

4. Geração - das representações geracionais e inversões que ocorrem no transe, onde jovens se tornam velhos e vice-versa; as entidades cantam e dançam como crianças, jovens ou velhos, independentemente de sua condição na vida "real";

5. Sexualidade - das inversões de gênero e de sexualidade, quais entidades podem ser assexuadas ou hipersexualizadas; homens podem ser mulheres e vice-versa, redefinindo ou legitimando experiências e papéis.

Cada entidade possui o seu repertório musical específico constituído por linhas ou pontos cantados, ${ }^{10}$ como são chamadas as cantigas, representando narrativas das entidades, de suas

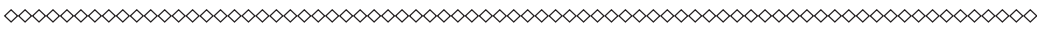

10 Os cantos das entidades são chamados de linhas ou pontos, termos que também são utilizados no contexto musical da umbanda, estudada por Mackelly Borges (2006), o que indica, também, o diálogo não somente religioso, como musical entre ambas as religiões. 
histórias e características particulares que José Jorge de Carvalho (1990, p. 135) considera como "claras histórias de anti-heróis":

Cada uma dessas entidades tem não só uma ou mais canções que a identifica, como também fala longamente e conta sua história de vida, com um vocabulário extremamente explícito e invariavelmente ligado à marginalidade e à prostituição. São claras histórias de anti-heróis: ladrões, assassinos, rufiães, putas, donas de cabaré, capangas, enfim, 'anti-sociais' de todo tipo e lugar.

Os pontos falam também sobre os territórios, as moradas místicas das entidades. Essa territorialidade sagrada na jurema é representada pelas matas, encruzilhadas, mares, rios e, em certos casos, até mesmo países.

As entidades trazem suas próprias cantigas, que são cantadas em português e carregadas de uma forte dose de ineditismo, embora tais entidades não sejam necessariamente consideradas compositoras num sentido convencional. ${ }^{11}$ Essa constante possibilidade de ineditismo dos pontos cantados integra o princípio da casualidade ou imprevisibilidade que representa um aspecto musical norteador para o repertório das entidades, embora, ainda que sejam desconhecidos, os novos pontos estarão dentro do mesmo padrão melódico, rítmico e temático dos demais pontos. A individualização das entidades religiosas é um dos principais fatores que geram o ineditismo dos pontos cantados. Logo, os pontos cantados de cada entidade consistem de narrativas autobiográficas. Em alguns casos, esses cantos narram uma temática infelizmente ainda em pauta para as mulheres: a violência sexual e doméstica, como é possível observar no ponto individual a seguir, onde o sujeito musical em questão pode ser tanto a mestra Luziara como a mestra Ritinha:

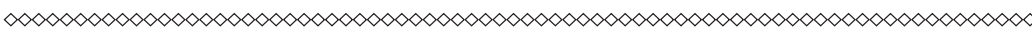

11 Assim como no candomblé de caboclo baiano, onde, diferentemente dos orixás, que possuem um repertório pré-estabelecido cantado em iorubá e transmitido oralmente de geração a geração, Sonia Chada Garcia discute como, no candomblé de caboclo, as entidades "trazem" suas "linhas", que podem ser completamente inéditas. (GARCIA, 2001, p. 133)
} 
Ponto individual da mestra Luziara ou Ritinha:

\author{
"Fui passada com 15 anos \\ Dentro da Rua da Guia. \\ Me chamam de Luziara, \\ Mas meu nome é Maria. \\ Minha mãe sempre dizia: \\ Minha filha olha o que faz. \\ Por que a minha vida \\ Era na beira do cais. \\ Um homem para mim \\ Tinha que ser marinheiro \\ Por que me dava carinho \\ E também me dava dinheiro. \\ Estava na beira do cais \\ Quando o navio apitou \\ Marinheiro me dê um abraço \\ Um aperto de mão \\ Minha boca beijou."
}

Antes de entrar para a análise do texto do ponto cantado em questão, é importante saber um pouco quem são as entidades mestras. Sua saudação é "salve as mestras! Saravá as mestras!" - estas, quando estavam em "matéria" e hoje enquanto "espírito", vivem na cidade da jurema (e do encantamento da jurema), nas encruzilhadas e cemitérios. São cultuadas no mês de março, quando comem galinha, azeite e farofa. Já em outubro, tem-se a "festa da pata", em que é oferecido caranguejo aos mestres e mestras, embora em março também se oferte.

A mestra é considerada uma poderosa entidade da "esquerda" da jurema, que bebe álcool e fuma. As mestras foram mulheres de larga experiência amorosa ou mesmo prostitutas. ${ }^{12}$ Neste caso,

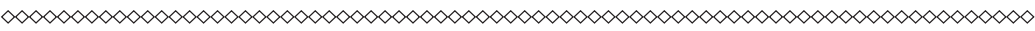

12 Maria do Carmo Brandão e Felipe Rios (2001, p. 169) mencionam mestras da jurema que morreram virgens e por isso ganharam o estatuto de princesas, como a Princesa Catarina e Princesa da Rosa Vermelha. Contudo, são difíceis de baixar. As mais comuns são "as que na 
a sexualidade é que está em evidência em primeiro plano, sendo o corpo um veículo de sua expressão. Elas bebem, fumam, falam palavrão, agem de maneira não correspondente às expectativas sociais vigentes. As mestras são espíritos de mulheres jovens que lidam majoritariamente com questões amorosas, pois são consideradas grandes conhecedoras do amor e do sexo.

A diferença entre as representações de gênero é nítida para mestras e mestres. ${ }^{13}$ Com cigarro e taça em punhos quando "descem", as mestras cantam suas cantigas, que narram suas trajetórias, personalidades e poderes. As cantigas das mestras geralmente falam sobre relacionamentos amorosos e histórias de vidas de mulheres geralmente empobrecidas e prostituídas.

O padrão rítmico das entidades mestras é o coco, gênero musical popular tradicional nordestino de origem afro-indígena, que também é uma dança realizada pelas entidades em suas performances. ${ }^{14}$ Contudo, o padrão rítmico da macumba também acompanha grande parte de seus pontos cantados. Em relação ao universo melódico das entidades mestras, tonalismo e modalismo são preponderantes, cujas estruturas melódicas dos pontos dialogam muito com o cancioneiro popular tradicional da região, caso do coco..$^{15}$

$\infty<\infty<\infty<\infty<\infty<\infty<\infty<\infty<\infty<\infty<\infty<\infty<\infty<\infty<\infty<\infty<\infty<\infty<\infty<\infty<\infty<\infty<\infty<\infty<\infty<\infty<\infty<\infty<\infty<\infty<\infty<\infty<\infty$ vida material foram 'mulheres de vida fácil', mulheres de rua e dos cabarés nordestinos." Essas últimas que estão presentes no terreiro Xambá e demais terreiros.

13 Os mestres representam uma masculinidade viril, embora geralmente sejam também brincalhões. Alguns eram viciados no jogo e na bebida, quando "descem" através do transe, "chegam" bêbados e ávidos por mais bebida e cigarros. Fumam cigarro de palha e falam com vocabulário considerado "dos tempos antigos", pois essas entidades viveram no início do século passado.

14 Padrão binário de andamento rápido e, portanto, dançante, cuja presença do trio de ilús (tambores sagrados) é fundamental, mas não indispensável em todas as casas de jurema pesquisadas. No Xambá, o coco não é somente um ritmo ou gênero musical muito representativo, como é uma festa pública de grandes proporções, que acontece todo 29 de junho, dia do aniversário de Mãe Biu, uma de suas mais importantes ialorixás.

15 No presente texto, não analiso transcrição musical do ponto cantado em questão por não ser este o objetivo de teor mais técnico e musical. Contudo, na minha tese de doutorado realizei mais de 20 transcrições musicais dos pontos das entidades femininas da jurema, incluindo padrões rítmicos, modos e escalas. (ROSA, 2009) 
Ritinha e Luziara são entidades regionais do Nordeste. Há indícios de Luziara em Alagoas, através de algumas narrativas do povo de santo do terreiro Xambá. Tal regionalismo se traduz em primeiro lugar no idioma, onde o português regionalizado é a tônica das falas e dos cantos que se apresentam em escalas modais e tonais com inclusão de trechos do cancioneiro popular. O mesmo está também presente nos aspectos instrumentais e performáticos, por exemplo, as entidades mestras, mas intimamente relacionadas a influências indígenas, onde o coco consiste num padrão rítmico preponderante que sempre é acompanhado por maracás indígenas e também pode ser chamado de "toré", assim como a performance ritual praticada por diversas comunidades indígenas do Nordeste. ${ }^{16}$

É importante lembrar de que estamos falando da prática religiosa da jurema sagrada no âmbito de um terreiro de culto aos orixás, entidades africanas, o que configura um momento de compartilhamento religioso e musical entre ambos os universos dos orixás e do culto da jurema. No referido ponto cantado da mestra Luziara ou Ritinha várias questões são evidenciadas.

Em primeiro lugar, a mestra narra seu próprio assassinato, confirmado com o termo de ser "passada", que significa ter sido morta, assassinada por seu parceiro sexual, aos 15 anos de idade, levantando aqui questões como a violência contra a mulher jovem

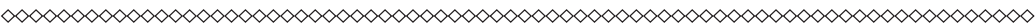

16 De acordo com Rodrigo Grünewald (2005, p. 27), o toré consiste numa "brincadeira indígena", ritual de canto e dança politicamente importante e, por vezes, relacionado à ingestão da bebida jurema, a mesma que se bebe no culto em questão, mas inserido num terreiro de culto aos orixás. 0 autor propõe uma etnomusicologia do toré que abrange desde "toantes", "cantigas",

"linhas", "torés", "benditos" a "sambas" etc., compondo um grande acervo de tradição oral até composições recentes passadas pelos "encantados", sob as influências regionais que menciono como o samba de coco e outros gêneros. Há também ocorrência de aspectos etnobotânicos ligados à execução musical do toré, configurando a relação da música com o xamanismo, destacando a ingestão da bebida jurema, "que acompanha o toré como maior sinal diacrítico entre o índio e o não-índio". Seguindo, o autor afirma que esse panorama "nos remete de novo para o fato de que ambos, toré e jurema, embora referencialmente indígenas onde quer que se manifestem, são elementos reatualizados em outros contextos não-indígenas". 
e o feminicídio, onde recorte de gênero e geração é preponderante e se configura como a segunda questão da análise.

Em terceiro lugar, embora no texto deste ponto cantado não haja uma explicação literal de ter sido assassinada pelo parceiro, o povo de santo complementa que, pelo fato dela ter sido prostituta, vivido pela "rua da Guia"e pela "beira do cais", conhecidas zonas de prostituição de Recife, ${ }^{17}$ ela foi morta por um de seus parceiros sexuais numa interpretação causa-efeito como processo natural de uma mulher prostituída e vítima de feminicídio. Tânia Swain (2004, p. 24) combate essa suposta naturalização histórica da prostituição como destino da mulher que foge ou é excluída do padrão de comportamento esperado pela lógica patriarcal:

Esta proposição - a mais antiga profissão do mundo - cria e reproduz a idéia da existência inexorável da prostituição, ligada à própria existência das mulheres, parte de seu destino biológico; nesta asserção é mantida, no senso comum, a noção da essência maléfica e viciosa das mulheres, que, através dos tempos, se concretiza na figura da prostituta, o lado sombrio e negativo da representação construída sobre a mulher-mãe na historicidade discursiva ocidental. Por outro lado, fica materializada e generalizada a idéia da condição inferior das mulheres ao longo da história, despossuídas de seus corpos e de sua condição de sujeito, no social e no político.

Em quarto lugar, o nome da mestra Luziara, que pode ser também chamada de Maria, ${ }^{18}$ lhe configura uma identidade "genérica", por ser um nome muito comum, sobretudo do Nordeste brasileiro. Uma mulher anônima, cuja condição já estabelecia o seu destino de ser vítima de violência, naturalizado por seu anonimato.

A quinta questão evidenciada pelo texto do ponto refere-se ao protagonismo do homem no canto da mestra, assim como a

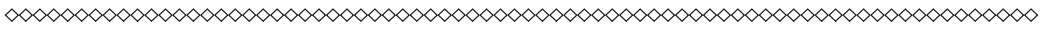

17 A Rua da Guia é uma rua em Recife muito famosa por ter sido zona de prostituição, e como fica numa área central de Recife, até hoje ainda é.

Esta mestra é também conhecida como Maria Luziara.
} 
relação mercantil entre ambos sujeitos, como é possível perceber no trecho do texto em que canta: "um homem para mim tinha que ser marinheiro porque me dava carinho e também me dava dinheiro.” Ao final, mesmo vítima da violência, ela pede ao marinheiro um abraço e o mesmo a beija.

Esse protagonismo masculino está diretamente relacionado ao que Tânia Swain (2006, p. 6) vai chamar de "dispositivo amoroso", ou seja, a dedicação ao amor na construção de um ideal feminino que só se constitui como sujeito quando em relação ao amor de outrem. Nos casos dessas mestras, pelo amor do homem, possivelmente um marinheiro:

O amor está para as mulheres como o sexo está para os homens: necessidade, razão de viver, razão de ser, fundamento identitário. O dispositivo amoroso investe e constrói corpos- em-mulher, prontos a se sacrificar, a viver no esquecimento de si pelo amor de outrem.

Veremos que o dispositivo amoroso das mestras não quebra com o binarismo heteronormativo homem-mulher, tampouco com a heterossexualidade compulsória. Contudo, na prática veremos também que, através de suas performances, há uma quebra da ordem de gênero pré-estabelecida. Mas a violência, contudo, ainda é uma tônica nas relações de gênero narradas pelas mestras, que, muitas vezes, são evidenciadas pelas performances das entidades, onde "a licensiosidade, o erotismo, a violência simbolizada e a escatologia crescem dramaticamente.” (CARVALHO, 1990, p. 135)

Em sexto lugar, a questão da violência racial não evidenciada no texto, mas que deve ser também considerada nesse contexto, visto que as mestras como entidades regionalizadas e nordestinas podem ser consideradas brancas, mas no imaginário do povo de santo estão muito mais próximas a uma representação étnico-racial "espelhada". Ao perguntar quem seriam as entidades mestras em termos físicos e fenotípicos, recebi a resposta de que 
eram "gente como a gente", que moraram em Recife, Jaboatão, Maceió etc. Ser como a gente nos remete à análise de quem é o povo de santo se não a maioria negra, afro-indígena e de baixa renda. Desse modo, a categoria raça se acomoda perfeitamente na discussão para melhor situar o entrelaçamento entre gênero, classe, sexualidade e geração:

Em relação ao tópico da violência, as mulheres negras realçaram uma outra dimensão do problema. Tem-se reiterado que, para além da problemática da violência doméstica e sexual que atingem as mulheres de todos os grupos raciais e classes sociais, há uma forma específica de violência que constrange o direito à imagem ou a uma representação positiva, limita as possibilidades de encontro no mercado afetivo, inibe ou compromete o pleno exercício da sexualidade pelo peso dos estigmas seculares, cerceia o acesso ao trabalho, arrefece as aspirações e rebaixa a auto-estima. (CARNEIRO, 2003, p. 122)

Nesse contexto, se tomamos o religioso como narrativa histórica oral, levantamos histórias de violência que mais se remetem à violência contra mulher, defendida por Segato (1999a, b, 2010) como feminicídio ou femigenocídio, quando corpos femininos representam territórios que são violados por uma ordem patriarcal que, legitimada e naturalizada, elabora um modus operandi de masculinidade atrelada à violência que se dá de forma específica contra o corpo feminino:

Os feminicídios são mensagens emanadas de um sujeito autor que só pode ser identificado, localizado, perfilado, mediante uma 'escuta' rigorosa desses crimes como atos comunicativos. É em seu discurso que encontramos o sujeito que fala, é em seu discurso que a realidade desse sujeito inscreve-se como identidade e subjetividade e, portanto, torna-se rastreável e reconhecível [...] Na língua do feminicídio, corpo feminino também significa território, e sua etimologia é tão arcaica quanto suas transformações são recentes. Tem sido constitutivo da linguagem das guerras, tribais ou modernas, que o corpo da mulher 
anexe-se como parte do país conquistado. A sexualidade investida sobre o mesmo expressa o ato domesticador, apropriador, quando insemina o território corpo da mulher. (SEGATO, 1999a, p. 276, 279)

\section{Ato IV: Música, políticas sexuais e violência}

Em termos de políticas sexuais, torna-se necessário definir espaços geopolíticos localizando as hegemonias com suas políticas de violência e as comunidades que representam as minorias e sofrem violência simplesmente por sê-las. Para tanto, Judith Butler (2008, p. 2, tradução nossa) nos alerta da importância de perguntarmos "em que tempo estamos?" e "onde nos situamos?", pois, "não pode haver consideração de políticas sexuais sem uma consideração crítica do tempo do agora." ${ }^{19}$

Várias articulações são necessárias para irmos além dos relativismos e discutirmos as hegemonias que se colocam enquanto definidoras de temporalidades (moderno, pós-moderno etc.). (BUTLER, 2008) Em relação ao contexto da jurema, isso serve tanto para o tempo de ontem, da mestra Luziara ou Ritinha, como para o tempo de agora, de músicas misóginas e racistas, e de uma indústria cultural avassaladora que investe na mesma enquanto produto que, por sua vez, é consumido sem o devido senso crítico aprofundado.

Retomando o slogan feminista de que "o pessoal é político", podemos acrescentar que o campo do sagrado é político. É possível falar em termos de políticas sexuais no campo do religioso e aqui, no universo da jurema, onde inversões de gênero muitas vezes geram deslocamentos numa perspectiva sociopolítica, sendo a homofobia e a lesbofobia resultantes de uma das violências que

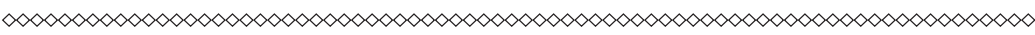

19 There can be no consideration of sexual politics without a critical consideration of the time of the now. 
esses deslocamentos estão sujeitos, daí a importância de se politizar as sexualidades e os seus diferentes lugares de (i)legibilidade:

O humano é diferencialmente entendido dependendo de sua raça, da legibilidade de sua raça, sua morfologia, a reconhecibilidade desta morfologia, seu sexo, a verificabilidade percentual deste sexo, sua etnicidade, o entendimento categórico desta etnicidade. Certos humanos são reconhecidos como menos que humanos, e esta forma de reconhecimento qualificado não lida com uma vida viável. Certos humanos não são reconhecidos de forma alguma como humanos, e isto lida ainda com outra forma de vida inviável. ${ }^{20}$ (BUTLER, 2004, p. 1, tradução nossa)

De modo geral, as representações de gênero das entidades espirituais da jurema são essencialistas no que tange ao masculino e feminino. Contudo, esse essencialismo é colocado em xeque quando vivenciado através da incorporação espiritual das pessoas pelas entidades, tornando a experiência do transe ou incorporação completamente não essencializada e, portanto, maleável:

Contêm sempre elementos de um ideal de gênero não essencialista, que permitiu e permite a maleabilidade adaptativa das relações familiares, sexuais e afetivas nas condições severíssimas que os afrodescendentes tiveram que suportar. ${ }^{21}$ (SEGATO, 2002, p. 336, tradução nossa)

Para tratar de representações e políticas sexuais, retomo a experiência de revelação já discutida em outro momento, quando um padrinho de jurema gay estava incorporado com seu mestre e interagia com uma mulher trans incorporada com a sua mestra, numa realidade compreendida pelo povo de santo como o diálogo

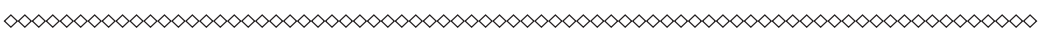

20 The human is understood differentially depending on its race, the legibility of that race, its morphology, the recognizability of that morphology, its sex, the perceptual verifiability of that sex, its ethnicity, the categorical understanding of that ethnicity. Certain humans are recognized as less than human, and that form of qualified recognition does not lead to a viable life. Certain humans are not recognized as human at all, and that leads to yet another order of unlivable life.

21 Contienens iemprelos elementos de un ideário de género no esencialista, que permitió y permite lamaleabilidad adaptativa de las relaciones familiares, sexuales y afectivas en las condiciones severísimas que los afro-descendientes tuvieron que soportar. 
espiritual entre duas entidades espirituais que transcendiam dos corpos físicos envolvidos: o mestre e a mestra. Ou quando uma filha de santo lésbica diz se identificar mais com sua entidade masculina, sendo vista pela comunidade como homem, a ponto de ser aceita como ogã, que toca os tambores sagrados - a princípio proibidos às mulheres nas cerimônias públicas -, e também ser iniciada no culto aos orixás e ficar em reclusão junto com dois homens, quando, na realidade, durante a iniciação, se considera a separação por sexo como regra básica. (ROSA, 2009b, p. 275)

O momento da incorporação da entidade espiritual é também um momento de inversão de papéis em relação ao padrão hegemônico preestabelecido que quebra com os binarismos de gênero e a lógica heteronormativa:

Enfim invocada e aludida na conversa ordinária, uma inumerável série de inversões transforma essa mitologia aparentemente convencional e hierárquica num discurso irônico sobre a sociedade brasileira, onde não apenas a determinação biológica é removida de seu lugar usual de suporte da ideologia, se não também o patriarcado e a hierarquia desestabilizados pelas práticas diárias. As fundações patriarcais de um estado 'doméstico' privatizado são também questionadas..$^{22}$ (SEGATO, 2002, p. 348, tradução nossa)

Sem dúvida, a experiência de políticas sexuais de agências, pessoas adeptas a essa religião, deve ser uma realidade a ser considerada. Contudo, não se pode negligenciar o teor explícito de desigualdade entre o glamour da visibilidade gay e a respectiva invisibilidade lésbica no contexto religioso, assim como as diferentes falas e, aqui especificamente, a experiência de violência

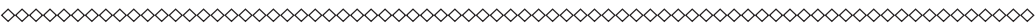

22 Enfin, invocada y aludida en la conversación ordinaria, una innumerable serie de inversiones transforma esa mitología aparentemente convencional y jerárquicae nun discurso irónico sobre la sociedade brasileña, donde no apenas la determinación biológica es removida de su lugar usual de soporte de la ideología, sino también el patriarcado y la jerarquia son desestabilizados por las prácticas diarias. Las fundaciones patriarcales de un estado "doméstico" privatizado son también cuestionadas. 
sexual sofrida por mulheres como as mestras, como nos mostra o ponto da mestra Luziara, que pode se estender para outras mestras. Nesta, é inscrita a violência de gênero ou feminicídio no corpo da mulher prostituída enquanto território violado pela ordem patriarcal e capitalista de gênero que naturaliza o assassinato da mulher que vivia à Rua da Guia, à beira do cais. Sobre essa naturalização, Marcela Lagarde (2004, p. 5) destaca que:

A violência de gênero já é percebida como um atentado aos direitos humanos das mulheres e um dos mais graves problemas sociais e de urgente atenção. Sabemos que não é natural: a violência de gênero é um mecanismo político cujo fim é manter as mulheres em desvantagem e desigualdade no mundo e nas relações com os homens, permite excluir as mulheres do acesso a bens, recursos e oportunidade; contribui a desvalorizar, denegrir e amedrontar as mulheres e reproduz o domínio patriarcal. A violência de gênero contra as mulheres e entre os homens recria a supremacia de gênero dos homens sobre as mulheres e lhes dá poderes extraordinários na sociedade. ${ }^{23}$ (LAGARDE, 2004, p. 5, tradução nossa)

Desse modo, reitero o objetivo deste artigo de analisar o feminicídio como categoria musical não somente para realizar uma viagem histórica da trajetória de vida de um sujeito silenciado pela violência e seu lugar de subalternidade, no caso, uma mestra assassinada que provavelmente viveu em Recife no início do século XX. Reforço, também, a importância da atualização das reflexões e enfretamentos da violência de gênero contra mulheres,

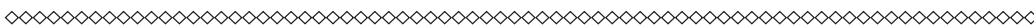

La violencia de género ya es percibida como un atentado a los derechos humanos de las mujeres y uno de los más graves problemas sociales y de urgente atención. Sabemos que no es natural: la violencia se incuba enlasociedad y enel Estado debido a lainequidad genérica patriarcal. La violencia de género es un mecanismo político cuyo fin es mantener a las mujeres en desventaja y desigualdade nel mundo y en las relaciones con los hombres, permite excluir a las mujeres del acceso a bienes, recursos y oportunidades; contribuye a desvalorizar, denigrar y amedrentar a lasmujeres y reproduce el dominio patriarcal. La violencia de género contra las mujeres y entre los hombres recrea la supremacía de género de los hombres sobre las mujeres y les da poderes extraordinários en la sociedade. 
tida como destino natural e inevitável de determinadas mulheres que fogem do padrão "respeitável" de família e de maternidade.

Em relação aos aspectos musicais dos pontos cantados das entidades espirituais, é relevante lê-los como sonoridades que, a depender do tipo de entidade, geram discursos de violência que se remetem a experiências de violência vividas, como é o caso do sujeito musical em questão, que pode e deve ser considerado como um discurso cuja autoria é de mulheres (as entidades mestras). Em termos mais amplos, aplicáveis a outros contextos, como o da música popular, é importante aprofundar esta análise para o campo dos discursos sobre as mulheres, caso da violência simbólica tão em voga em segmentos musicais altamente vendáveis pela indústria musical e consumidos pela população - como é o caso do pagode baiano, sem o devido debate em relação à misoginia, sobretudo em relação às mulheres negras, como requisito comercial imprescindível deste mercado musical.

Em relação a esse último, é importante ressaltar: trata-se de uma discussão que ainda carece de maior problematização no campo de estudos feministas e sobre música no Brasil, distanciada de discursos demonizantes, com alto teor classista e racista de um lado, mas que também não caia num neoliberalismo simplificado e relativista do outro. Em ambos os discursos, ainda que de modos diferenciados, está reforçada a lógica perversa de violência ainda recorrente, fruto de uma lógica patriarcal e capital hegemônica, para a qual o feminicídio (material ou simbólico) é a tônica e o corpo feminino pode tanto ser violável quanto vendável.

Acredito que, ao considerarmos a dimensão de gênero no campo do musical, abrimos brechas para uma escuta qualificada da polifonia de vozes de mulheres silenciadas pela violência. A partir dessa escuta, não somente podemos compreender as diferentes razões para que essa violência ocorra, mas, sobretudo, ao tratarmos da violência simbólica e de narrativas de feminicídio, 
podemos elaborar novos caminhos, novas rotas para transformar essa realidade onde há uma naturalização do extermínio moral e físico das mulheres e tudo que se refere ao feminino, o que inclui também as mulheres trans e homens gays vítimas de homofobia por serem considerados "afeminados".

\section{Referências}

A MORTE e a donzela. Direção: Roman Polanski. Intérpretes: Sigourney Weaver, Ben Kingsley, Stuart Wilson e outros. [Los Angeles]: NBO, 1994. (103 min.), son., color.

ARAÚJO JUNIOR, S. et al. A violência como conceito na pesquisa musical; reflexões sobre uma experiência dialógica na Maré, Rio de Janeiro. Revista Transcultural de Música, Barcelona, n. 10 dez., 2006.

BENTO, B. Brasil: país do transfeminicídio. [São Paulo, 2014].

Disponível em: <http://www.clam.org.br/uploads/arquivo/

Transfeminicidio_Berenice_Bento.pdf $>$. Acesso em: 2015.

BELL hooks: cultural criticism (rap music). YouTube, 10 dez. 2006.

Disponível em: <https://www.youtube.com/watch?v=Xtoanes_L_g . Acesso em: 2015.

BORGES, M. R. Gira de escravos: a música dos exus e pombagiras no centro umbandista Rei de Bizara. 200f. 2006. Dissertação (Mestrado em Música) - Escola de Música, Universidade Federal da Bahia, Salvador, 2006.

BRANDÃO, M. do C.; RIOS, L. F. O catimbó-jurema do Recife. In:

PRANDI, R. (Org.). Encantaria brasileira: o livro dos mestres, caboclos e encantados. Rio de Janeiro: Pallas, 2001. p. 160-181.

BRASIL. Lei n. 11.340 de 7 de agosto de 2006. Cria mecanismos para coibir a violência doméstica e familiar contra a mulher, nos termos do $\$$ $8^{\circ}$ do art. 226 da Constituição Federal, da Convenção sobre a Eliminação de Todas as Formas de Discriminação contra as Mulheres. Disponível em: <http://www.planalto.gov.br/ccivil_03/_ato2004-2006/2006/lei/ 111340.htm>. Acesso em: 2015.

BRASIL. Lei n. 13.104, de 9 de março de 2015. Altera o art. 121 do Decreto-Lei n. 2.848, de 7 de dezembro de 1940 - Código Penal, para 
prever o feminicídio como circunstância qualificadora do crime de homicídio, e o art. $1^{\circ}$ da Lei n. 8.072, de 25 de julho de 1990, para incluir o feminicídio no rol dos crimes hediondos. Disponível em: $<$ http: // www.planalto.gov.br/ccivil_03/_Ato2015-2018/2015/Lei/L13104.htm>. Acesso em: 2015b.

BRASIL. Dilma Rousseff sanciona lei que torna hediondo o crime de feminicídio. Portal Brasil, Brasília, DF, 9 mar. 2015a. Disponível em: <http://www.brasil.gov.br/governo/2015/03/dilma-rousseffsanciona-lei-que-torna-hediondo-o-crime-de-feminicidio $>$. Acesso em: 2015.

BUTLER, J. Sexual politics, torture, and secular time. The British journal of sociology. v. 59, n. 1, p. 1-23, mar., 2008.

BUTLER, J. Undoing gender. New York: Routledge, 2004.

CANCIAN, N. Lei 'antibaixaria' limita músicas maliciosas na Bahia. Folha de São Paulo, São Paulo, 27 mar. 2012. Disponível em: <http://www1. folha.uol.com.br/cotidiano/1068198-lei-antibaixaria-limita-musicasmaliciosas-na-bahia.shtml>. Acesso em: 10 abr. 2012.

CARNEIRO, S. Mulheres em movimento. Estud. av., São Paulo, v. 17, n. 49, p. 117-132, set./dez., 2003. Disponível em: <http://www.scielo. $\mathrm{br} /$ scielo.php? pid=S0103-40142003000300008\&script=sci_arttext $>$. Acesso em: 15 abr. 2009.

CARVALHO, J. J. “Jurema”. In: LANDIM, L. (Org.). Sinais dos tempos: diversidade religiosa no Brasil. Rio de Janeiro: ISER, 1990. p. 131-145.

CUSICK, S. G. Music as torture / Music as weapon. Transcultural Music Review, Barcelona, n. 10, 2006. Disponível em: <http://www.sibetrans. $\mathrm{com} /$ trans/articulo/152/music-as-torture-music-as-weapon $>$. Acesso em: 10 abr. 2008.

DAVIS, A. Masked Racism: Reflections on the Prison Industrial Complex. Color lines, 10 set. 1998. Disponível em: <http://www.colorlines.com/ articles/masked-racism-reflections-prison-industrial-complex $>$. Acesso em: 10 ago. 2014.

FRITH, S. What is Bad Music? In: WASHBURNE, C.; DERNO, M. (Ed.). Bad music: the music we love to hate. New York: Routledge, 2004. p. 15-35. 
GARCIA, A. S. Relações de gênero, raça, classe e desigualdades socioocupacionais. In: SEMINÁRIO INTERNACIONAL FAZENDO GÊNERO. Florianópolis, 2010. Anais eletrônicos... Florianópolis: Instituto de Estudos do Gênero, 2010. Disponível em: <http://www. fazendogenero.ufsc.br/9/resources/anais/1275930508_ARQUIVO_ ArtigoCongressoCienciasSociais.pdf $>$. Acesso em: 12 maio 2011.

GARCIA, S. M. C. Um repertório musical no seio do culto aos orixás, em Salvador - BA. Tese (Doutorado em Música) - Escola de Música, Universidade Federal da Bahia, Salvador, 2001.

GAULTIER, A. M. O. A Manera de Introducción: La materialidad de lo musical y su relación con la violência. Transcultural Music Review, Barcelona, n. 10, dez., 2006.

GRÜNEWALD, R. de A. “As múltiplas incertezas do toré”. In:

GRÜNEWALD, R. A. (Org.). Toré: regime encantado do índio do Nordeste. Recife: FUNDAJ, Massagana, 2005. p. 13-38.

JANE, S. Beautiful fragments of a traumatic memory: synaesthesia, sesame street, and hearing the colors of an abusive past. Revista Transcultural Music Review, Barcelona, n.10, 2006.

JOHNSON, B.; CLOONAN, M. (Org.) Dark side of the tune: popular music and violence. Farnham: Ashgate, 2009.

LAGARDE, M. Por la vida y la libertad de las mujeres, fin del Feminicidio. Cimac Noticias, Cidade do México, fev., 2004. Disponível em: <http://www.cimacnoticias.com/especiales/comision/diavlagarde. htm>. Acesso em: 1 jun. 2011.

MCCLARY, S. Paradigm dissonances: music theory, cultural studies, feminist criticism. Perspectives of new music, v. 32, n. 1, p. 68-85, winter, 1994.

NASCIMENTO, C. G. do. Entrelaçando corpos e letras: representações de gênero nos pagodes baianos. 2009. 195f. Dissertação (Mestrado em Estudos Interdisciplinares sobre Mulheres, Gênero e Feminismo) Faculdade de Filosofia e Ciências Humanas, Universidade Federal da Bahia, Salvador, 2009.

PINHEIRO, G. 'Lei antibaixaria' é aprovada na Bahia; projeto limita músicas contra violência. Estadão, São Paulo, 28 mar. 2012. Disponível em: <http://brasil.estadao.com.br/blogs/radar-pop/lei-antibaixaria-eaprovada-na-bahia/>. Acesso em: 2015. 
PRANDI, R. Herdeiras do Axé. São Paulo: Hucitec, 1996. p. 139-164. Disponível em: <http://www.fflch.usp.br/sociologia/prandi/pombagi. htm>. Acesso em: 20 ago. 2015.

QUARTETO de cordas n. 14 (Schubert). Wikipedia, 2015. Disponivel em: $<$ https://pt.wikipedia.org/wiki/Quarteto_de_cordas_n\%C2\%BA_14_ (Schubert) $>$. Acesso em: 2015.

ROSE, T. Hip Hop images: women and exploitation. YouTube, 7 jul. 2014. Disponível em: <https: / www.youtube.com/watch? $=$ JhVOi8XQ7P8>. Acesso em: 2015.

ROSA, L. As juremeiras da nação Xambá (Olinda, PE): músicas, performances, representações de feminino e relações de gênero na jurema sagrada. 2009. 359f. Tese de (Doutorado em música Etnomusicologia)-Escola de Música, Universidade Federal da Bahia, Salvador, 2009b.

ROSA, L. A. Músicas e performances no feminino: princípios teológicos e alguns idiomas presentes no culto da jurema sagrada. In: CONGRESSO BRASILEIRO DE UMBANDA DO SÉCULO XXI: do sincretismo à convergência, 2., 2009. Anais... São Paulo: Faculdade de Teologia Umbandista, 2009a. p. 1-9.

SARDENBERG, C. B. A violência simbólica de gênero e a lei "antibaixaria” na Bahia. Observatório de Monitoramento da Lei Maria da Penha - OBSERVE, 30 ago. 2011. Disponível em: <http://www. observe.ufba.br/noticias/exibir/344>. Acesso em: 15 maio 2012.

SARKISSIAN, M. Gender and music. In: MYERS, H. (Ed.). Ethnomusicology: an introduction. New York: W. W. Norton, 1992. p. 337-348.

SEGATO, R. L. Femi-geno-cidio como crimen en el fuero internacional de los Derechos Humanos: el derecho a nombrar el sufrimiento en el derecho. Texto ampliado de "El derecho a nombrar el sufrimiento en el Derecho”. In: POLACK, D.; DESPOUY, L. ETCHEGOYEN, A. (Comp.). Voces $y$ silencios de la discriminación: acesso a la justicia: conferencia 2009. Buenos Aires: El Mono Armado, 2010. Disponível em: <http:// www.larevuelta.com.ar/pdf/Femi-geno-cidio-como-crimen-Segato. pdf $>$. Acesso em 10 maio 2014.

SEGATO, R. L. Identidades políticas y alteridades históricas: una crítica a las certezas del pluralismo global. Revista Nueva Sociedad, Buenos Aires, n 178, mar., p. 104-125, 2002. 
SEGATO, R. L. Território, soberania e crimes de segundo Estado: a escritura nos corpos das mulheres de Ciudad Juarez. Revista Estudos Feministas, Florianópolis, v. 13, n. 2, p. 265-285, 1999a.

SEGATO, R. L. Okarilé: uma toada icônica de Iemanjá. Revista do Patrimônio Histórico e Artístico Nacional, Rio de Janeiro, n. 28, p. 237-253, 1999b.

SOVIK, L. Aqui ninguém é branco. Rio de Janeiro: Aeroplano, 2009.

SPIVAK, G. C. Pode o subalterno falar? Belo Horizonte: Ed. UFMG, 2010.

SWAIN, T. N. Entre a vida e a morte, o sexo. Labrys: Estudos

Feministas, Brasília, DF, v. 12, n. 10, jul./dez., 2006. Disponível em: <http://www.labrys.net.br/labrys10/livre/anahita.htm>. Acesso em: nov. 2006.

SWAIN, T. N. Banalizar e naturalizar a prostituição: violência social e histórica. Unimontes científica, Montes Claros, v. 6, n. 2, p. 23-28, jul./ dez., 2004.

TROTTA, F. Festa, amor e sexo: um estudo de caso sobre o ambiente musical e afetivo do forró. In: ENCONTRO NACIONAL DA ABET, 4. Maceió, 2008. Anais.... Maceió: ABET/UFAL, 2008. p. 214-220.

WERNECK, J. Introdução. In: WERNECK, J.; MENDONÇA, M.; WHITE, E. (Org.). O livro da saúde das mulheres negras: nossos passos vêm, de longe. 2.ed. Rio de Janeiro: Pallas/Criola, 2006. p. 9-11. 


\section{QUEM É QUEM}

Alinne de Lima Bonetti

É antropóloga, licenciada em Ciências Sociais pela Universidade Federal do Rio Grande do Sul (UFRGS), mestra em Antropologia Social pela Universidade Federal de Santa Catarina (UFSC) e doutora em Ciências Sociais, área de estudos de gênero, pela Universidade Estadual de Campinas (Unicamp). Atualmente, é professora adjunta da Universidade Federal do Pampa (Unipampa). Dentre os seus temas de interesse e pesquisa, estão: gênero, poder, política, cidadania, movimentos sociais, feminismo, desigualdades e suas interseccionalidades, teoria feminista, antropologia feminista e teoria antropológica.

\section{Andréa Pacheco de Mesquita}

Mulher, feminista, assistente social pela Universidade Estadual do Ceará (UECE), mestra em Educação Brasileira pela Universidade Federal do Ceará (UFC) e doutora pelo Programa de Estudos Interdisciplinares sobre Mulher, Gênero e Feminismo pela Universidade Federal da Bahia (UFBA). É professora da Universidade Federal de Alagoas (UFAL) na Faculdade de Serviço Social e sócia-fundadora da Organização de Mulheres Maria 
Mariá. É do Conselho Estadual dos Direitos da Mulher do Estado de Alagoas. Atua nas áreas de serviço social, educação, direitos humanos, gênero e feminismo.

\section{Cândida Ribeiro Santos}

Graduação em Ciências Sociais pela Universidade Salvador (UNIFACS), mestrado em Ciências Sociais pela Universidade Federal da Bahia (UFBA) e doutora em Estudos Interdisciplinares sobre Mulheres, Gênero e Feminismo, também pela UFBA, com período Sanduíche de oito meses (fevereiro a setembro de 2013) na Universidade Complutense de Madrid/Espanha. Experiência como pesquisadora do Observe - Observatório de Monitoramento da Aplicação da Lei Maria da Penha e em outras pesquisas relacionadas a gênero, violência de gênero, políticas públicas e feminismo, atuais áreas de interesse e atuação.

\section{Cecilia Maria Bacellar Sardenberg}

Feminista com graduação em Antropologia Cultural - Illinois State University (1977), mestrado em Antropologia Social Boston University (1981), doutorado em Antropologia Social Boston University (1997), e estágios pós-doutorais como visiting fellow no Institute of Development Studies (IDS), University of Sussex, Inglaterra (2007/2013). É uma das fundadoras do NEIM, atuando como professora associada IV no Departamento de Antropologia e nos Programas de Pós-Graduação em Estudos Interdisciplinares sobre Mulheres, Gênero e Feminismo (PPG/ NEIM) e de Antropologia (PPGA) da UFBA. Foi coordenadora pelo NEIM do Programa Nacional de Cooperação Acadêmica da Coordenação de Aperfeiçoamento de Pessoal de Nível Superior (Procad/Capes) com a UFSC e coordenadora nacional do Observe - Vem atuando, junto ao IDS, como coordenadora (2006/2014) do Grupo da América Latina do Consórcio do Programa de Pesquisas - Research Programme Consortium - sobre o Empoderamento 
das Mulheres (Pathways of Womens Empowerment), financiado pelo Department for International Development, da GrãBretanha, e liderando o grupo de pesquisa do Projeto Trilhas do Empoderamento e Mulheres. Integra o Comitê de Gênero e Sexualidade da Associação Brasileira de Antropologia, com interesses voltados principalmente para: antropologia feminista, estudos feministas, feminismo e políticas públicas, gênero e desenvolvimento e gênero e corpo. É bolsista de produtividade em pesquisa do CNPq.

\section{Ermildes Lima da Silva}

Assistente social, mestra pelo Programa de Pós-Graduação em Estudos Interdisciplinares sobre Mulheres, Gênero e Feminismos pelo Núcleo de Estudos Interdisciplinares sobre a Mulher da Universidade Federal da Bahia (NEIM/UFBA). Foi Bolsista do Programa Institucional de Bolsas de Iniciação Científica (PIBIC) no período de 2011 a 2012, cuja pesquisa foi monitorar e avaliar a aplicação da Lei Maria da Penha nas Delegacias Especializadas de Atendimento à Mulher na cidade de Salvador.

\section{Eulália Lima Azevedo}

Doutora e mestre em Ciências Sociais pela Universidade Federal da Bahia (UFBA). Graduação em Biologia pela UFBA. Atualmente, é pesquisadora associada e docente da Pós-Graduação lato sensu do Núcleo de Estudos Interdisciplinares sobre a Mulher (NEIM) da UFBA e docente na Universidade Salvador Laureate International Universities (UNIFACS). É membro da linha de pesquisa: Gênero, Poder e Políticas Públicas (NEIM/UFBA). Tem experiência na área de política e sociologia, atuando principalmente nos seguintes temas: políticas públicas, introdução à sociologia, sociologia clássica, sociologia contemporânea, estado e sociedade civil, gerações, idosos, gênero, relações de gênero, feminismos e educação continuada. 
Jayce Layana Lopes Callou

Bacharel em Psicologia pela Universidade Federal do ValedoSão Francisco (Univasf), mestra e doutoranda pelo Programa de PósGraduação em Estudos Interdisciplinares sobre Mulheres, Gênero e Feminismo (PPGNEIM/UFBA), realizando trabalhos na linha de pesquisa: gênero, poder e políticas públicas. Especialização em Teoria da Clínica Lacaniana pela Escola Brasileira de Psicanálise. Possui trajetória acadêmica voltada para atuação nas áreas de saúde coletiva, gênero, feminismo, violência contra a mulher e políticas públicas.

Juliana Sampaio

Graduada em Psicologia pela Universidade Federal de Pernambuco (UFPE), mestrado em Serviço Social pela UFPE e doutorado em Saúde Pública pela Fundação Oswaldo Cruz. Atualmente, é professora adjunta III da Universidade Federal da Paraíba (UFPB), membro do Núcleo de Estudos em Saúde Coletiva da Paraíba e membro da Rede Associação Brasileira de Psicologia Social (Abrapso-Paraíba). Tem experiência na área de Psicologia, com ênfase em psicologia social e da saúde, atuando principalmente com os seguintes temas: atenção básica, gestão do cuidado, políticas públicas, direitos sexuais e reprodutivos e gênero.

\section{Laila Andresa Cavalcante Rosa}

Cantautora feminista, instrumentista e etnomusicóloga pernambucana. Doutora em Etnomusicologia pela Universidade Federal da Bahia (UFBA), com bolsa da Coordenação de Aperfeiçoamento de Pessoal de Nível Superior (Capes) de doutorado sanduíche de um ano realizado na New York University (Nova York/2007). Desde 2010 é professora adjunta de Etnomusicologia da Escola de Música e do Programa de Pós-Graduação em Música da UFBA. É pesquisadora permanente do Núcleo de Estudos 
Interdisciplinares da Mulher (NEIM) e coordenadora do Feminaria Musical: grupo de pesquisa e experimentos sonoros, que integra a linha gênero, arte e cultura do NEIM. Em 2013 lançou o CD Água Viva: um disco líquido, trabalho autoral livremente inspirado na obra homônima de Clarice Lispector e nos arquétipos dos orixás femininos Iemanjá e Oxum (www.soundcloud.com/laila-rosa). Áreas de interesse/atuação são: gênero, epistemologias feministas pós-coloniais, etnomusicologia, religiões afro-brasileiras e suas tradições musicais, música popular tradicional do Nordeste brasileiro, compositoras brasileiras, branquitude e relações étnico-raciais, sexualidades, educação musical (com foco na articulação entre as leis n. 11.769/2008, 10.639/2003 e 11.645/2008) e violino e rabeca nos contextos da música popular e tradicional brasileira.

\section{Leila Linhares Barsted}

Advogada, feminista, coordenadora executiva da organização não governamental Cidadania, Estudo, Pesquisa, Informação e Ação (Cepia), membro e ex-coordenadora do Comitê de Especialistas do Mecanismo de Monitoramento da Convenção de Belém do Pará da Organização dos Estados Americanos (OEA), representante da Cepia no Observatório de Monitoramento da Aplicação da Lei Maria da Penha (Observe), membro da Comissão de Segurança da Mulher do Estado do Rio de Janeiro. Participou do Consórcio de ONGs que elaborou a proposta que deu origem à Lei Maria da Penha. Coordena projetos nas áreas de violência de gênero, direitos sexuais e reprodutivos e avaliação de políticas públicas com ênfase na aplicabilidade da Lei Maria da Penha.

\section{Luana Simões Pinheiro}

Doutoranda em Sociologia pela Universidade de Brasília (UnB), é economista e mestre em Sociologia pela mesma instituição, com dissertação enfocando a participação política das mulheres na Câmara 
dos Deputados no período pós-Constituinte. Atualmente, é técnica de pesquisa e planejamento do Instituto de Pesquisa Econômica Aplicada (DF) e coordenadora da Coordenação de Igualdade de Gênero e Raça, da Diretoria de Estudos e Políticas Sociais. Tem elaborado e publicado estudos na área social, especialmente sobre as questões de gênero e raça. Colaborou no desenho e na implementação de importantes estratégias do Governo Federal para o combate às desigualdades de gênero e raça, como os Planos Nacionais de Políticas para as Mulheres. Entre 2007 e 2011 foi coordenadora geral de planejamento e gestão da informação da Secretaria de Políticas para as Mulheres, da Presidência da República.

\section{Márcia Queiroz De Carvalho Gomes}

Doutora e mestra em Ciências Sociais pela Universidade Federal da Bahia (UFBA), graduada em Terapia Ocupacional pela Escola Bahiana de Medicina e Saúde Pública. Foi co-coordenadora nacional do Observatório de Monitoramento da Lei Maria da Penha (Observe). Atualmente, é professora Adjunta da Universidade Federal da Paraíba (UFPB). Tem experiência nas áreas de terapia ocupacional, sociologia e antropologia, atuando principalmente nos seguintes temas: terapia ocupacional, gerontologia, relações intergeracionais e de gênero, políticas públicas e envelhecimento e violência contra a mulher.

\section{Márcia Santana Tavares}

Professora adjunta II do Curso de Serviço Social, coordenadora e professora do Programa de Pós-Graduação em Estudos Interdisciplinares sobre Mulher, Gênero e Feminismo (PPG/ NEIM) da Universidade Federal da Bahia (UFBA); mestre em Sociologia pela Universidade Federal de Sergipe (UFS) e doutora em Ciências Sociais pela UFBA; vice-coordenadora do Observatório de Monitoramento da Lei Maria da Penha (Observe). 
Tem artigos publicados nas revistas Serviço Social e Sociedade, Interseções, Labrys, Praia Vermelha e Políticas Públicas, entre outras. Desenvolve estudos na área de políticas públicas, família, relações de gênero e sexualidade e violência contra as mulheres.

\section{Maria Eunice Kalil}

Médica e mestre em Saúde Comunitária pela Universidade Federal da Bahia (UFBA), técnica da Secretaria Estadual de Saúde, integrante da Secretaria Executiva do Observatório de Violências e Acidentes do Estado da Bahia, do Grupo Dinamizador do Fórum Comunitário de Combate à Violência (FCCV), do Instituto Mulheres pela Atenção Integral à Saúde e aos Direitos Sexuais e Reprodutivos (Imais) e da Regional Bahia da Rede Feminista de Saúde.

\section{Maria Gabriela Hita}

Graduada em Sociologia pela Universidade Federal da Bahia (UFBA), mestra em Ciências Sociais pela Facultad Latino Americana de Ciencias Sociales (Flacso/México) e doutora em Ciências Sociais pela Universidade Estadual de Campinas (Unicamp), com estágios pós-doutorais na Universidade de Manchester (Grã Bretanha-2008/2013). Atualmente, é professora associada I do Departamento de Sociologia, onde leciona desde 1994, e nos Programas de Pós-Graduação em Ciências Sociais (PPGCS) e Estudos Interdisciplinares sobre Mulheres, Gênero e Feminismo (PPG/NEIM) na UFBA a partir de 2004. Foi Coordenadora do Laboratório Interdisciplinar de Desigualdades Sociais (LIDES) do PPGCS entre 2010 e 2012. Tem experiência em teoria social e feminista, com enfoque fenomenológico, e desenvolve pesquisas em questões socioculturais e políticas sobre pobreza urbana, família, saúde e raça. É pesquisadora do Núcleo de Estudos em Ciências Sociais e Saúde (ECSAS) da UFBA. 


\section{Maria Therezinha Nunes}

Advogada, mestra pelo Programa de Pós-Graduação em Estudos Interdisciplinares sobre Mulheres, Gênero e Feminismo (PPGNEIM/UFBA), especialista em Análise da Constitucionalidade pela Universidade de Brasília (UnB); Direito de Família pela Pontifícia Universidade Católica de Minas Gerais (PUC-MG); e em Direitos Humanos das Mulheres: Teoria e Prática, pela Universidad de Chile. Desenvolve estudos nas temáticas da Lei Maria da Penha, violência doméstica e familiar, equidade, relações de gênero e políticas públicas. Atualmente, desenvolve suas atividades na coordenação do Programa Pró-Equidade de Gênero e Raça do Senado Federal e integra a Comissão da Mulher Advogada - Ordem dos Advogados do Brasil (OAB-DF).

\section{Pedro Ferreira}

Técnico de Planejamento e Pesquisa da Diretoria de Estudos e Políticas Sociais (Disoc) do Instituto de Pesquisa Econômica Aplicada (Ipea).

\section{Rubia Abs da Cruz}

Advogada, diretora de justiça da Secretaria da Justiça e Direitos Humanos do Estado do Rio Grande do Sul, especialista em Direitos Humanos das Mulheres pela Universidade do Chile e especialista em Sistema ONU pela American University College of Law (Washington-DC), coordenadora geral da Themis Assessoria Jurídica e Estudos de Gênero de 2005 a 2011, membra do Comitê Latino-Americano e do Caribe para a Defesa dos Direitos da Mulher (Cladem).

Simone Oliveira de Lacerda

Bacharela em Humanidades pela Universidade Federal da Bahia (UFBA), graduada em Serviço Social da UFBA, realizou in- 
tercâmbio no curso de Serviço Social da Universidade de Coimbra através do programa de intercâmbio da UFBA/Santander. Foi voluntária no período de 2011 a 2012, cuja pesquisa foi monitorar e avaliar a aplicação da Lei Maria da Penha nas Delegacias Especializadas de Atendimento à Mulher na cidade de Salvador. Também pós-graduanda em Docência no Ensino Superior. Possui interesse nas áreas de direitos e políticas sociais, políticas públicas, violência doméstica e familiar e gênero.

\section{Suely Maria Costa Lobo}

Bacharel em Psicologia, com Formação de psicóloga e licenciatura pela Universidade Federal da Bahia (UFBA), e especialista em Psicologia Clínica. Atuou, por sete anos e meio, no atendimento a mulheres em situação de violência no Centro de Referência Loreta Valadares, da Prefeitura Municipal de Salvador. Atualmente, desenvolve suas atividades profissionais no Centro de Atenção Psicossocial I (CAPS) Prof. Luiz Meira Lessa, em Salvador.

\section{Telia Negrão}

Jornalista e mestre em Ciência Política, especialista em Gestão Pública Participativa. Pesquisadora associada ao Núcleo Interdisciplinar de Estudos sobre Mulher e Gênero da Universidade Federal do Rio Grande do Sul (UFRGS) e membro do corpo docente da Fundação Universidade Empresa de Tecnologia e Ciências (Fundatec). Coordenadora do Coletivo Feminino Plural e membro do Colegiado da Rede Feminista de Saúde e da Rede de Saúde das Mulheres Latino-americanas e do Caribe (RSMLAC). Integra o Comitê mundial da campanha Women Won't Wait e do Comitê Gestor da Campanha Ponto Final na Violência Contra Mulheres e Meninas. Relatora da sociedade civil junto ao Comitê Cedaw desde 2002 e coordenadora do Projeto do Consórcio de Monitoramento à Cedaw no Brasil - Ação Permanente do Movimento de Mulheres. 


\begin{tabular}{|c|c|}
\hline & COLOFÃo \\
\hline Formato & $15 \times 23 \mathrm{~cm}$ \\
\hline Tipologia & Leitura News e leitura Sans $10 / 16$ \\
\hline Papel & $\begin{array}{l}\text { Alcalino } 75 \mathrm{~g} / \mathrm{m}^{2} \text { (miolo) } \\
\text { Cartão Supremo } 300 \mathrm{~g} / \mathrm{m}^{2} \text { (capa) }\end{array}$ \\
\hline Impressão & Edufba \\
\hline Acabamento & I. Bigraf \\
\hline Tiragem & 300 \\
\hline
\end{tabular}

